Министерство образования и науки Российской Федерации

Уральский федеральный университет

имени первого Президента России Б. Н. Ельцина

\author{
И. С. Белик
}

\title{
ЭКОЛОГО-ЭКОНОМИЧЕСКАЯ БЕЗОПАСНОСТЬ
}

Рекомендовано учебно-методическим советом УрФУ в качестве учебного пособия для студентов, обучающихся по программе бакалавриата по направлению подготовки 080100.62 Экономика

Екатеринбург

Издательство Уральского университета 
УДК 502: 338(075.8)

ББК 65.28-98я73

Б 43

Рецензенты:

д-р экон. наук, проф. В. А. Антропов

(каф. управления социальными

и экономическими системами

ГОУ ВПО Уральского государственного

университета путей сообщения);

д-р экон. наук В. П. Ануфриев

(дир. ООО «Уральский центр

энергосбережения и экологии»)

Научный редактор - д-р экон. наук, проф. Александр Дмитриевич Выварец

\section{Белик И.С.}

Б 43 Эколого-экономическая безопасность : учеб. пособие / И. С. Белик.

Екатеринбург : Изд-во Урал. ун-та, 2013. - 224 с.

ISBN 978-5-7996-1021-0

В учебном пособии рассматривается понятийно-категориальный аппарат эколого-экономической безопасности, подходы и методический инструментарий ее оценки, приводится методика рейтинга и отбора инвестиционных проектов на основе критериев эколого-экономической безопасности, механизм учета эколого-экономической ситуации территории в инвестиционной сфере. Учебное пособие прививает навыки формирования диагностической картины эколого-экономической безопасности региона, развивает аналитические способности студентов по оценке текущего эколого экономического состояния региона. Пособие может использоваться как для самостоятельной подготовки студентов, так в теоретической и практической части курса.

Учебное пособие подготовлено при финансовой поддержке Российского гуманитарного научного фонда (проект РГНФ № 11-32-00215a1 ).

Библиогр.: 46 назв. Табл. 45. Рис. 24. Прил. 4.

ISBN 978-5-7996-1021-0 


\section{ОГЛАВЛЕНИЕ}

Глава 1. Понятие и основные положения эколого-экономической безопасности 5

1.1. Формы взаимодействия общества и природы ............................ 5

1.2. Эколого-экономические системы ............................................ 19

1.3. Понятийный аппарат эколого-экономической безопасности... 27 Глава 2. Оценка и диагностика эколого-экономической безопасности региона.

2.1. Подходы к оценке эколого-экономической безопасности региона.

2.2. Диагностика состояния эколого-экономической безопасности 65

2.3. Роль эколого-экономической безопасности в реализации модели устойчивого развития региона 87 Глава 3. Инструментарий учета в стратегиях развития региона оценки эколого-экономической безопасности 100

3.1. Обоснование выбора инвестиционной политики на основе оценки уровня эколого-экономической безопасности региона ........ 100 3.2. Отбор инвестиционных проектов по критериям .................... 107 эколого-экономической безопасности 107

3.3. Эколого-экономическая эффективность производства, ориентирующая на выбор экологически безопасной модели развития ……................................................................... 118

3.4. Бюджетный эффект от реализации проектов направленных на снижение риска здоровью населения от изменения качества ОС ... 127 4. Международные механизмы экологического регулирования 163

4.1. Экологические последствия климатических изменений........ 163 
и качества ОС

4.2. Формы международного экологического сотрудничества .... 178 Библиографический список .............................................................. 199

Приложение 1 ............................................................................ 204

Приложение 2 .................................................................................... 205

Приложение 3 .......................................................................... 209

Приложение 4 ......................................................................................... 214 


\section{ГЛАВА 1. ПОНЯТИЕ И ОСНОВНЫЕ ПОЛОЖЕНИЯ ЭКОЛОГО- ЭКОНОМИЧЕСКОЙ БЕЗОПАСНОСТИ}

Политика обеспечения защиты человека и окружающей природной среды в период своего формирования строилась по отдельным направлениям, главным образом, на основе здравого смысла, и в меньшей степени на результатах системных научных исследований. При этом защищенность человека как наиболее чувствительного объекта экосистемы рассматривалась как защищенность собственно природной среды, что в рамках доминирующего теоретического подхода (охрана окружающей среды (OC)) означало не превышение техногенного воздействия на человека и природу более установленного уровня предельно допустимых норм. На практике требования обеспечения безопасности человека и ОС сводились к условиям создания безопасных для человека технологий, т. е. в основном к инженерным задачам. Господствующая теория определяла природоохранную политику, как строящуюся на принципе «реагировать и выправлять».

Однако накопление отрицательного опыта развития социально-экологоэкономических систем, опровергло постулат о «пороговом» характере воздействия факторов опасности на человека и ОС и обнаружило, что обеспечение защиты человека, не гарантирует безопасность растительному и животному миру [2].

\section{1. Формы взаимодействия общества и природы}

Окружающая или антропогенная (созданная человеком) среда состоит из многих компонентов. В окружающей среде можно (в общем плане) выделить такие составляющие, как литосфера, гидросфера, атмосфера, биосфера. В каждом конкретном случае все эти составляющие ОС взаимодействуют между собой.

\section{Справка [41]}

Литосфера - это верхний слой земной коры, наружная твердая каменная оболочка земного шара, толщиной $30-80$ км. Природные процессы, происходящие в литосфере, приводят к землетрясениям. Из верхнего слоя литосферы добывают полезные ископаемые. Но наибольшее значение для человечества имеет тончайшая пленка на верхней поверхности 
литосферы - почва, т. е. поверхностный плодородный слой земной коры, созданный под совокупным влиянием климата (тепла, воды, воздуха), рельефа, растений, животных, микроорганизмов и деятельности человека.

Гидросфера включает в себя воду в трех агрегатных состояниях жидком, твердом и газообразном. Вода в жидком состоянии на $98 \%$ сосредоточена в Мировом океане и его окраинных частях, называемых морями. Пресная вода рек и озер составляет лишь весьма небольшую часть гидросферы, но именно она наиболее важна для жизнедеятельности человека. Вода в твердом состоянии сосредоточена в основном в ледниковых щитах Антарктиды и Гренландии, в многолетних арктических льдах, в ледниках на вершинах гор, а также в виде зимнего снега. Газообразная вода - часть атмосферы.

Атмосфера - газовая оболочка Земли, наиболее мобильная часть окружающей природной среды. Для жизнедеятельности человека основное значение имеет нижняя часть атмосферы - тропосфера, высотой до 10 км. В атмосферу выбрасываются вредные газы, частицы твердых веществ и мельчайшие капли жидких загрязнителей. В ряде промышленных центров человеку трудно дышать из-за выбросов металлургических комбинатов и выхлопных газов автомобилей. Деятельность человека оказывает влияние и на атмосферу Земли в целом: падает содержание кислорода, увеличивается содержание углекислого газа, меняются атмосферные потоки и, в конечном счете, климат.

Биосфера - это растения, животные, микроорганизмы и другие живые существа, живущие на земле, в воде, в воздухе. Загрязнения окружающей природной среды обычно весьма вредно действуют на живые организмы, приводят к сокращению их численности. Кроме того, многие из них способны концентрировать в себе опасные вещества, представляющие заметную опасность для здоровья человека.

Характеристика параметрического пространства ОС и живущего в ней человека представлена в табл.1. (приведена по М. И. Львовичу, 1986, [22]).

Таблица 1

Распределение воды в биосфере

\begin{tabular}{|c|c|}
\hline Локализация или форма & Объем, $10^{6} \mathrm{Kм}^{3}$ \\
\hline Океаны & 1380 \\
\hline Осадочные породы & 210 \\
\hline Ледники & 16,7 \\
\hline Подземные воды & 0,25 \\
\hline Поверхностные континентальные воды & 0,025 \\
\hline Атмосферная влага & 0,013 \\
\hline
\end{tabular}


Океаны занимают наибольший объем ОС, так если воду, находящуюся в разных гидрогеологических формах, равномерно распределить по земному шару, то образуются слои, толщина которых составит [41]:

- для Мирового океана - 2700 м,

- для ледников -100 м,

- для подземных вод -15 м,

- для поверхностных пресных вод $-0,4$ м,

- для атмосферной влаги $-0,03$ м

При этом 97 \% Мирового океана не взаимодействуют с солнечным излучением, поэтому он вносит незначительный вклад в планетарную биомассу (табл. 2).

Справка [21].

Масса организмов определенной группы (продуцентов, консументов, редуцентов) или сообщества в целом называется биомассой. Прирост биомассы в экосистеме, созданной за единицу времени, называется биологической продукцией (продуктивностью). Различают первичную и вторичную продукцию сообщества Первичная продукиия - биомасса, созданная за единицу времени продуцентами, делится на валовую и чистую.

Валовая первичная продукиия (общая ассимиляция) - это общая биомасса, созданная растениями в ходе фотосинтеза. Часть ее расходуется на поддержание жизнедеятельности растений (траты на дыхание 40 - 70 \%). Оставшаяся часть составляет чистую первичную продукиию (чистая ассимиляция), которая в дальнейшем используется консументами и редуцентами, или накапливается в экосистеме.

Вторичная продукция - биомасса, созданная за единицу времени консументами. Она различна для каждого следующего трофического уровня. Если в экосистеме скорость прироста растений выше темпов переработки ее консументами и редуцентами, то это ведет к увеличению биомассы продуцентов. Если при этом присутствует недостаточная утилизация продуктов распада в цепях разложения, то происходит накопление мертвого органического вещества. Это проявляется в заторфовывании болот, образовании мощной лесной подстилки и др. В стабильных экосистемах биомасса остается постоянной, т. к. практически вся продукция расходуется в цепях питания.

Вся пресная вода составляет лишь около 5,8 \% водных ресурсов Земли [18]. Пресной воды на Земле достаточно, но распределена она крайне неравномерно. Так, 60 \% пригодной для питья воды приходится на 10 государств. Более 1,2 млрд чел. не имеют доступа к чистой питьевой воде, а половина 
человечества страдает от ее плохой очистки. По данным Всемирной организации здравоохранения (BО3), 80 \% всех болезней и 25 млн преждевременных смертей в год определяются отсутствием или плохим качеством питьевой воды.

Таблица 2

Биомасса разных типов экосистем (Н.Ф. Реймерс, 1990)

\begin{tabular}{|c|c|c|c|c|c|}
\hline \multirow[t]{2}{*}{ Тип экосистем } & \multirow[t]{2}{*}{$\begin{array}{c}\text { Площадь, } \\
10^{6} \text { км }\end{array}$} & \multicolumn{2}{|c|}{$\begin{array}{c}\text { Биомасса растений, } \\
\text { кг/м }{ }^{2}\end{array}$} & \multicolumn{2}{|c|}{ Мировая величина } \\
\hline & & колебания & в среднем & $\begin{array}{l}\text { биомасса } \\
\text { растений, } \\
10 *^{*} \text { т }\end{array}$ & $\begin{array}{l}\text { биомасса } \\
\text { животных, } \\
10{ }^{*} \text { т }\end{array}$ \\
\hline Влажные тропические леса & 17,0 & $6-80$ & 45 & 765 & 330 \\
\hline $\begin{array}{l}\text { Тропические сезонно-зеленые } \\
\text { леса }\end{array}$ & 7,5 & $6-80$ & 35 & 260 & 90 \\
\hline $\begin{array}{l}\text { Вечнозеленые леса умеренного } \\
\text { пояса }\end{array}$ & 5,0 & $6-200$ & 35 & 175 & 50 \\
\hline $\begin{array}{l}\text { Листопадные леса умеренного } \\
\text { пояса }\end{array}$ & 7,0 & $6-60$ & 30 & 20 & 110 \\
\hline Тайга & 12,0 & $6-40$ & 20 & 240 & 57 \\
\hline Лесо-кустарниковые сообщества & 8,5 & $2-20$ & 6 & 50 & 40 \\
\hline Саванна & 15,0 & $0,2-15$ & 4 & 60 & 220 \\
\hline Лугостепь & 9,0 & $0,2-5$ & 1,6 & 14 & 60 \\
\hline Тундра и высокогорье & 8,0 & $0,1-3$ & 0,6 & 5 & 35 \\
\hline Пустыни и полупустыни & 18,0 & $0,1-4$ & 0,7 & 13 & 8 \\
\hline $\begin{array}{l}\text { Сухие пустыни, скалы, ледники и } \\
\text { т. п. }\end{array}$ & 24,0 & $0-0,2$ & 0,02 & 0,5 & 0,02 \\
\hline Культивируемые земли & 14.0 & $0,4-12$ & 1 & 14 & 6 \\
\hline Болота и марши & 2,0 & $3-50$ & 15 & 30 & 20 \\
\hline Озера и водотоки & 2,0 & 0,01 & 0,02 & 0,05 & 10 \\
\hline $\begin{array}{l}\text { Материковые экосистемы в } \\
\text { целом }\end{array}$ & 149 & - & 12 & 1837 & \\
\hline Открытый океан & 332,0 & $0-0,005$ & 0,003 & 1,0 & 800 \\
\hline Зоны апвеллинга & 0,4 & $0,005-0,1$ & 0,02 & 0,008 & 4 \\
\hline Континентальный шельф & 26,6 & $\begin{array}{l}0,001- \\
0,04\end{array}$ & 0,01 & 0,27 & 160 \\
\hline Заросли водорослей и рифы & 0,6 & $0,04-4$ & 2 & 1,2 & 12 \\
\hline Эстуарии & 1,4 & $0,01-6$ & 1 & 1,4 & 21 \\
\hline Морские экосистемы в целом & 361 & - & 0,01 & 3,9 & 997 \\
\hline Общая биомасса Земли * & 510 & - & 3,6 & 1841 & 2002 \\
\hline
\end{tabular}

По оценке Всемирного банка, для решения этой проблемы необходимо 600 млрд долл. Потребление воды в 2000 г. увеличилось по сравнению с 1950 г. в 3 


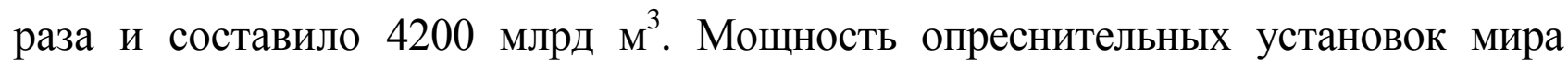
неуклонно растет и составляет сейчас примерно 10 м пресной воды в год, что удовлетворяет около одного процента мировой потребности.

Площадь суши составляет 29 \% от площади поверхности Земли $\left(135,783 * 10^{6}\right.$ км$\left.^{2}\right)$. Считается, что $20 \%$ расположено в слишком холодном климате, $20 \%$ - в засушливом, 12 - 15\% покрыто совсем маломощными почвами. В современном мире основная масса продуктов питания производится на обрабатываемых землях, их доля в общем продовольственном обеспечении людей составляет 88 \%, еще 10 \% дают пастбища и только $2 \%$ - Мировой океан. Общая площадь земель, удовлетворяющих требованиям сельского хозяйства, составляет 5 млрд га [18].

Формой отношений, возникающих между ОС и основным видом человеческой деятельности (материальным производством) является природопользование. Данная форма взаимоотношений трансформируется в процессе экономического развития, которое с позиции концепции устойчивого развития должно осуществляться в направлении экологизации экономики.

Как известно в основе экономического роста лежат три фактора (или три вида капитала):

- трудовые ресурсы (человеческий капитал);

- искусственно созданные средства производства (физический, искусственный, произведенный капитал);

- природные ресурсы (природный капитал).

Выделяют следующие функции природного капитала [21]:

1. Ресурсная. Заключается в обеспечении природными ресурсами производства товаров и услуг.

2. Экологическая. Заключается в обеспечении природой различного рода регулирующих функций: ассимиляция загрязнений и отходов, регулирование климата и водного режима, озонового слоя и др.

3. Природно-естественная. Услуги природы, связанные с эстетическими, этическими, моральными, культурными, историческими аспектами. 
Недооценка всех функций природного капитала и игнорирование экологического фактора является общим диагнозом традиционных моделей экономики (рыночной, плановой, административно-командной). В экономической системе стоимостной оценке чаще всего подвергаются только функции обеспечения человека природными ресурсами, при этом экологические услуги, как правило, не имеют цены. Это положение является причиной порождения глобальных экологических проблем, экономический ущерб от которых огромен, а в будущем может принять угрожающие размеры.

На протяжении развития человеческого общества складывались различные концепции его отношений с ОС, основными из которых являются следующие [1]:

1. Концепция потребительского отношения к окружающей среде и ее ресурсам (техногенный тип экономического развития).

2. Концепция невмешательства в природу.

3. Концепция ноосферы.

4. Концепция ограничения экономического развития, потребностей и народонаселения.

5. Концепция устойчивого развития.

\section{Справка [1]}

Концепция потребительского отношения к $\mathrm{OC}$ и еe ресурсам (техногенный тип экономического развития) может быть господствующей как в странах с плановой, так и с рыночной экономикой. Суть этой концепции заключается в том, что природа воспринимается как кладовая, из которой должны извлекаться ресурсы для развития материального производства и создания богатства общества. Этот тип экономического развития можно охарактеризовать как природоемкий (природоразрушающий) тип, базирующийся на использовании искусственных средств производства, созданных без учета экологических ограничений.

Характерными чертами техногенного типа развития являются:

- быстрое и истощительное использование невозобновимых природных ресурсов (прежде всего полезных ископаемых); 
- сверхэксплуатация возобновимых ресурсов (почвы, лесов, рек) со скоростью, превышающей возможности их воспроизводства и восстановления;

- объемы загрязнений и отходов, превышающие ассимиляционные возможности ОС.

Наносимый ОС в результате человеческой деятельности экономический ущерб, является стоимостной оценкой деградации природных комплексов и загрязнения ОС. Для техногенного типа экономического развития свойственны значительные экстерналии, или внешние эффекты. В природопользовании их можно охарактеризовать как негативные эколого-экономические последствия хозяйственной деятельности, которые не принимаются во внимание субъектами этой деятельности.

Существуют различные модели техногенного типа развития, при этом можно выделить две главные модели [22]: фронтальной экономики и охраны OC.

На протяжении всей истории развития человечества основное внимание в теории и практике уделялось двум факторам экономического роста: труду и капиталу. Природные ресурсы предполагались неистощимыми и уровень их потребления по отношению к возможностям их восстановления и запасам не рассматривался в числе определяющих параметров. Не принимались во внимание также последствия экономического развития в виде различного рода загрязнений, деградации ОС и ресурсов. Не изучались и обратные влияния, обратные связи между экологической деградацией и экономическим развитием, состоянием трудовых ресурсов, качеством жизни населения. Такую экономическую систему называют «фронтальной экономикой» или, по известному определению американского ученого К. Боулдинга, «ковбойской экономикой» (характеризуется неограниченными территориями, ресурсами и т.д.).

\section{Справка [1]}

Сущность концепции фронтальной экономики не вызывала возражений вплоть до самого последнего времени. Тогда пришло осознание необходимости коренного изменения экономических воззрений в 
направлении учета экологического фактора. Человечество должно вести себя с учетом многочисленных ограничений, живя в замкнутой и ресурсодефицитной системе, которую Боулдинг сравнил с «космическим кораблем Земля». Космический корабль является замкнутой системой, в которой усилия должны быть направлены на рециклирование материалов, сокращение отходов, охрану исчерпаемых источников энергии и переход на потенциально неограниченные источники энергии, такие как, например, солнечная энергия.

Нарастание экологической напряженности, осознание опасности дальнейшего развития фронтальной экономики вынудило многие страны попытаться учесть экологические факторы. В связи с этим появилась концепция, которую можно определить как конщепщию охраны $О С$. Видимой реакцией на рост экологической угрозы явилось создание более чем в 100 странах государственных структур, связанных с охраной природы, также быстрое развитие получила законодательная деятельность, связанная с принятием законов и актов, регламентирующих нормы, процедуры природопользования. С 70-х гг. ХХ в. началось и активное международное сотрудничество в сфере охраны ОС. Были приняты сотни многосторонних и двусторонних договоров, регулирующих и регламентирующих природопользование в международном масштабе. В рамках конщепции охраны ОС некоторым странам удалось добиться определенной экологической стабилизации, однако качественного улучшения не произошло. Общая идеология данной концепции эколого-экономического развития не изменилась по сравнению с концепцией фронтальной экономики. Главными попрежнему являются интересы экономики, максимальное наращивание производства, широкое использование достижений научно-технического прогресса с целью более полного удовлетворения потребностей людей. В этих условиях природоохранная деятельность, «траты на охрану ОС представляются как нечто противостоящее экономическому росту» [1], вследствие чего экологический фактор признается необходимым, но сдерживающим экономическое развитие.

Концепщия невмешательства в природу противоположна предыдущей концепции и может рассматриваться в чисто теоретическом аспекте. Сущность 
данной концепции состоит в том, что все процессы в природе осуществляются на основе объективных законов и все попытки вмешательства в природу с целью исправления ее «дефектов» без учета законов ее развития оборачиваются серьезными последствиями для человека и ОС [22].

При современном уровне технологий такой тип развития может привести к свертыванию промышленности, ориентации на натуральное сельское хозяйство, что, несомненно, скажется на понижении жизненных стандартов общества.

\section{Справка [1]}

Одним из вариантов этого направления можно считать конц̧епциюю экотопии. Неспособность добиться радикального изменения в отношениях между экономикой и окружающей средой привела к появлению данной концепции. Это в чистом виде теория всяческого ограничения экономического развития. Это даже не нулевой рост Д. Медоуза, а скорее минусовый рост. Основные направления этой концепции: возврат к природе, биологическое и культурное разнообразие, простые технологии, отказ от научно-технического прогресса, который только разрушает ОС, и т. д. Кроме того, внимание в различных видах экотопии уделяется нравственному совершенствованию, социальным, религиозным и духовным аспектам совершенствования человека. Эти концепции лежат в основе программ партий «зеленых» во многих странах. В целом изменение приоритетов экономического развития на основе концепции экотопии представляется малореальным.

Концеепциия ноосферы вытекает из учения о ноосфере, разработанного русским академиком В. И. Вернадским, и французским философом Тейяр де Шарденом [1]. Сущностью концеепции ноосферы является особое значение идей естественного права и естественной справедливости, указывающих на нормы, с которыми должен считаться человек, стремясь установить сбалансированные отношения между природой и обществом, обеспечить равновесие и гармонию в их взаимоотношении на основе преобразования человека в соответствии с законами природы, природными императивами, благодаря чему он способен сохранять за собой меняющиеся на каждом историческом этапе функции регуляции и контроля над социальными и естественными процессами [22].

Концеепчия ограничения экономического развития, потребностей u народонаселения явилась реакцией на резкое истощение в $60-70-е$ гг. XX в. 
природных ресурсов, высокие уровни загрязнения окружающей природной среды, т. е. на деградацию природы. Авторами данной концепции являлись американские ученые Дж. Форрестер, Д. Медоуз и другие члены Римского клуба, неправительственного научно-исследовательского международного объединения, образованного в 1968 г. Эта международная неправительственная организация была образована итальянским промышленником, вице-президентом компании «FIAT» Аурелио Печчеи с целью обсуждения и разработки перспектив мирового развития на глобальном уровне.

Справка [31]

Доклад Д. Медоуза и его коллег «Пределы роста» (1972) получил мировой резонанс и стал своего рода классической работой в области концепций мирового развития.

Исследование шло по пяти глобальным направлениям мировой динамики:

1) ускоряющаяся индустриализация; 2) быстрый рост населения; 3) нарастание голода; 4) истощение невозобновимых ресурсов; 5) ухудшение состояния ОС.

Различные варианты модели мировой динамики показывали, что вследствие исчерпания природных ресурсов, роста загрязнения ОС к середине XXI в. на Земле должен разразиться кризис, мировая катастрофа: голод, сокращение численности населения, эпидемии и т. д. От катастрофы спасал только один вариант - «нулевой рост». В соответствии с концепцией «нулевого роста» человечество должно стабилизировать численность населения, прекратить промышленный рост, инвестировать и развивать только сельское хозяйство для увеличения производства продовольствия и сферу услуг, а в промышленности только возмещать износ фондов.

Первый доклад Римского клуба (профессора Д. Медоуза «Пределы роста») привлек внимание во всем мире, по причине того, что в нем был подвергнут сомнению основной тезис мейнстрима о рациональности и целесообразности экономического роста. Авторы доклада отстаивали вывод о наличии жестких пределов экономического развития, роста численности и загрязнения ОС, обусловленных конечностью природных ресурсов и ассимиляционного потенциала биосферы. Выводы ученых основывались на результатах, полученных на моделях системной динамики, учитывающих многообразные обратные связи в системе «общество-природа» и использующих принцип экстраполяции тенденций, свойственных динамике выделенных факторов (период с 1900 по 1970 гг.).

Рассматривалось три сценария (модели): первый - базовый (сохранение основных закономерностей); второй - удвоения имеющихся запасов природных ресурсов (ускоренного роста); третий - частичном 
решении энергетической проблемы при сохранении других лимитирующих факторов. Рекомендации авторов состояли в необходимости жесткого контроля за всеми введенными в модель параметрами.

Через 20 лет появляется новая работа Д. Медоуза «За пределами роста», основной постулат которой состоит в следующем: «есть пределы росту, но нет - развитию». Между тем до сих пор акценты в экономике делаются на росте, понимаемом как количественное увеличение, а не как развитие, при котором необходимы качественные изменения. Пределами роста, по Медоузу, являются пределы интенсивности потоков, т. е. пределы источников обеспечивать поток ресурсов и пределы потоков поглощать отходы. Причина наступления пределов состоит в том, что население и капитал в мировой системе растут экспоненциально и при такой ситуации количественно растущая экономика разрушает ресурсную базу, что ведет к коллапсу.

В дальнейшем было опубликовано более 20 докладов, которые в большинстве своем отмечали умножение проблем, связанных с ухудшением состояния ОС, и неэффективностью усилий принимаемых на международном уровне. Постепенно идеи физических пределов социально-экономического роста стали уступать место задачам, связанным с выбором правильности направления экономического развития, отражающего качественное улучшение жизни, т. е. не требующее обязательного количественного увеличения потребления ресурсов, что в итоге привело в конце 80-х гг. научную общественность к идее устойчивого развития.

Одним из докладов Римскому клубу, получившим большую известность, стала работа М. Месаровича и Э. Пестеля «Человечество на перепутье» (1974). В ней модель мирового развития рассматривалась как многоуровневая иерархическая система с учетом геофизических, экологических, технологических, демографических и экономических факторов, по-разному проявляющихся и взаимодействующих в различных странах. Основные предложения авторов сводились к концепции «органического развития» на базе динамического равновесия за счет замедления экономического роста в развитых странах. При этом в докладе показывалась историческая тупиковость существующей модели развития мировой динамики. 
Важным выводом докладов Римскому клубу явилось положение о необходимости замедления роста и стабилизации численности населения планеты: при современном уровне технологического развития, ограниченности запасов природных ресурсов Земля не в состоянии удовлетворить и обеспечить нормальные потребности быстро растущего населения [1].

Конщепџия устойчивого развития (sustainable development) является одной из современных, наиболее распространенных и поддерживаемых мировым сообществом концепций взаимодействия государства и ОС. Ее появление и признание связано с природоохранной деятельностью ООН (см. раздел 1.2.). Концепция устойчивого развития получила закрепление и развитие в российском законодательстве об окружающей среде (Указы Президента РФ - от 04.02.94 «О государственной стратегии Российской Федерации по охране ОС и обеспечению устойчивого развития» и от 01.04 .96 «О концепции перехода Российской Федерации к устойчивому развитию»).

\section{Принципы взаимодействия в системе «природа-общество»}

Человек и используемые им современные технические средства все более интенсивно воздействуют на природную среду, поэтому изменения в любых компонентах природной среды не могут быть в достаточной степени проанализированы без соотнесения их с деятельностью общества. В современных условиях становится очевидным, что возрастающее техногенное действие общества на природную среду приводит к возрастанию воздействия измененной людьми природы на развитие самого общества.

Со временем более отчетливо проявляется необходимость согласования темпов и характера развития современного общества с возможностями биосферы, в которую общество структурно включено как элемент целостной системы. Противоречие между бесконечными возможностями развития общественного богатства и ограниченными компенсаторными возможностями биосферы становится основным противоречием для развития системы «природа-общество». Разрешить которое можно в том случае, если общество возьмет на себя функции обеспечения восстановительной способности природы. 
Это наиболее сложный и дорогостоящий путь, однако, при существующем состоянии природной среды, только он открывает возможности для дальнейшего прогресса общества. Поэтому обществу надлежит отказаться от устоявшихся догм «традиционного природопользования» и опираться на такие принципы, которые отражают все взаимоотношения в системе «природа -общество». Такими принципами взаимодействия природы и общества можно считать следующие [22]:

\section{1. Принщуип оптимального соответствия общества и природной средьл.}

Вытекает из требований системного подхода. Взаимодействие должно быть действительно взаимным, обмен веществом и энергией в процессе производства должен быть действительно эквивалентным, а использование вещества и энергии человеком должно быть циклическим, непрерывным, безотходным, аналогичным процессам природы. Общество должно выполнять определенную работу в динамике вещественно-энергетических процессов природы, в поддержании целостности биосферы, как и другие представители живого вещества биосферы. Способ выполнения этой функции определяется способом развития общества на основе процесса труда: обеспечение целостности биосферы может быть реализовано на базе познания и использования естественных процессов.

2. Принщии ориентацуии на естественное равновесие биосферы.

Целостность биосферы должна рассматриваться как важнейший природный ресурс человечества, а задача поддержания целостности - как генеральная цель в системе природопользования. Отсюда значения меры использования любых ресурсов биосферы (включая низкорентабельные) должны быть рассчитаны и соблюдаться с учетом закона синергии во взаимосвязях биосферы.

3. Принциип компенсац̧ии производимых у природной средьл изъятий соответственно свойственным им значениям меры. Данный принцип предполагает детальный мониторинг размера «благ», приносимых каждым отдельным компонентом природной среды для развития всей системы, и строгий регламент дальнейших действий по возврату системе всех ее рабочих свойств в 
полной мере.

\section{4. Принщип экологической чистоть человеческой деятельности.}

Подразумевает полную утилизацию побочных продуктов производства и бытового потребления. Сущность труда обычно связана с производственной деятельностью. Однако для эквивалентности обмена труд должен не только обеспечивать производство продукта, но и противоположный процесс деструкцию всего созданного с последующей утилизацией или депонированием. Только при этом возможно полное сопряжение производственных процессов с природными с созданием социобиогеоценозов.

5. Принцуип комплексности и экологической обоснованности принимаемых в природопользовании ремений. Одним из наиболее важных аспектов этого принципа следует считать необходимость планирования долгосрочных решений над краткосрочными.

6. Принциип обеспечения приоритета общественного интереса при решении проблем природопользования. Обеспечение подлинного социального прогресса и систематическое повышение качества жизни, основным критерием которого является здоровье человека, обусловлено здоровой и гармоничной окружающей средой. Проблемы отношения к природе сливаются с проблемами радикального преобразования общества в направлении достижения все более полной гармонии людей, как в организации собственной жизни, так и в развитии отношений с природой.

Соблюдение указанных принципов в любых видах природопользования открывает возможность достаточно полной гармонии человека в отношении с окружающей средой и возможности дальнейшего существования и развития общества.

\section{Вопросы и задания для самопроверки}

1. Охарактеризуйте структуру биосферы.

2. Где проходят верхние и нижние границы биосферы?

3. Какие компоненты биосферы выделил В. И. Вернадский?

4. В каких частях биосферы наблюдается максимальная плотность жизни?

5. Основные формы взаимодействия общества и природы.

6. Раскройте содержание понятия «природные ресурсы».

7. Раскройте содержание понятия «природные услуги». 
8. Опишите модели техногенного типа развития.

9. Раскройте содержание функций природного капитала.

10. Опишите основные концепции отношений в системе «природа-общество».

11. Раскройте содержание принципов взаимодействия природы и общества.

\section{Рекомендуемая литература}

1. Акимова Т. А. Экономика устойчивого развития : учеб/ пособие /Т. А. Акимова, Ю. Н. Мосейкин. М. : Изд-во «Экономика», 2009.

2. Масленникова И. С. Управление экологической безопасность и рациональным использованием природных ресурсов : учебник / И. С. Масленникова, В. В. Горбунова. СПб. : СПбГИЭУ, 2011.

3. Проблемы устойчивого развития социально-экономических систем. /А. И. Татаркин, В. В. Криворотов, И. С. Белик [ и др. ]; под редакцией А. И. Татаркина. Изд-во: Экономика, 2012.

\section{2. Эколого-экономические системы}

Применение системного подхода к анализу проблем безопасности направлено на раскрытие целостности объекта, на выявление многообразных типов связей в нем и выработку на этой основе единого представления о макросистеме, на создание теоретической модели ее функционирования. Системный подход - методологчческое направление в науке, основная задача которого состоит в разработке методов исследования и конструирования сложно организованных объектов - систем разных типов и классов [17].

С точки зрения системного подхода управление устойчивым развитием сложных систем (эколого-экономических) рассматривается как способность системы оставаться относительно неизменной в течение определенного периода вопреки внутренним и внешним возмущениям, а процесса развития как необратимые качественные изменения системы, сопровождаемые обычно количественными переменами.

Содержание данного определения подчеркивает, что в ходе развития системы могут меняться соотношения между ее компонентами, т. е. усиливаться одни связи и ослабляться другие, при этом устойчивость системы сохраняется. Причина способности удержать динамическое равновесие обнаруживается в постоянстве (неизменности) ее основных свойств [17]. 
Фундаментальный принцип поведения сложных систем - это периодическое чередование стадий эволюции и инволюции, развертывания и свертывания, взрыва активности, схождения к центру, интеграции и расхождения, дезинтеграции, частичного распада.

«В теории систем сложность означает не только нелинейность, но и огромное число элементов с большим числом степеней свободы. Все макроскопические системы, такие как камни или планеты, облака или жидкости, растения или животные, популяции животных организмов или человеческие общества, состоят из элементов или компонентов (таких, как атомы, молекулы клетки или организмы). Поведение отдельных элементов в сложных системах с огромным числом степеней свободы не может быть ни предсказано, ни прослежено в прошлом...» [22]. Применительно к функционированию живых систем самым ярким примером сложности является существование биосферы и составляющих ее экосистем.

Изменения в сообществах могут быть циклическими и поступательными [22]. Циклические изменения - периодические изменения в биоценозе (суточные, сезонные, многолетние), при которых биоценоз возвращается к исходному состоянию.

Суточные циклы связаны с изменением освещенностью температуры, влажности и других экологических факторов в течение суток. Суточные ритмы проявляются в изменении состояния и активности живых организмов в течение суток. Например, чередование световой и темновой фаз фотосинтеза у растений, сна и бодрствования у животных.

Сезонная цикличность связана с изменением экологических факторов в течение года и наиболее сильно выражена в высоких широтах, где велик контраст зимы и лета. Сезонная изменчивость проявляется не только в изменении состояния и активности, но и количественного соотношения отдельных видов. На определенный период многие виды выключаются из жизни сообщества, впадая в спячку, оцепенение или улетают в другие районы. 
Многолетняя изменчивость связана с флуктуациями климата или другими внешними факторами (степень разлива рек), либо с внутренними причинами (особенности жизненного цикла растений, повторения массового размножения животных).

Поступательные изменения - изменения в биоценозе, которые в конечном счете приводят к смене этого сообщества другим. Сукцессия - последовательная смена биоценозов (экосистем), выраженная в изменении видового состава и структуры сообщества. Ослабленные внешним воздействием экосистемы не в состоянии поддерживать параметры среды и они начинают претерпевать изменения, в дальнейшем при новых их значениях образуется другая экосистема, находящаяся в экологическом равновесии с новой окружающей средой. Примерами сукцессии является опустынивание степей, зарастание озер, образование болот и др.

\section{Пример [22]}

До середины 1920-х гг. на севере острова Сахалин произрастал лес. Когда после окончания Гражданской войны японцы эвакуировались с этой территории, они вырубили этот лес и вывезли древесину. Лес на этом месте уже не восстановился, а образовалась «антропогенная тундра». Физические и химические параметры данной территории не претерпели существенных изменений, а экосистема погибла. Такой параметр, как объем изымаемой биомассы, имел для этой системы критическое значение - так называемую «точку невозврата», когда невозможно сохранить целостность данного системного образования со всем набором параметров и функций. Северосахалинская экосистема воспроизводила ОС, пригодную для своего существования. Ослабленная внешним воздействием экосистема была не в силах совершать работу по своему поддержанию (недостаточным оказался сукцессионный потенциал), параметры среды (в том числе физические и химические) претерпели изменения, и при их новых значениях образовалась другая экосистема, находящаяся в экологическом равновесии с новой окружающей средой, но существенно слабее, чем вырубленный когда-то лес. Лес на севере Сахалина, уничтоженный в середине 1920-х гг., возник в других условиях, в другой окружающей среде, нежели осталась после его вырубки.

\section{Bывод}

Процесс образования экосистемы длительный, со своими сукцессионными фазами, и он представляет собой поиск экологического равновесия с другими начальными условиями, отличными от «антропогенной экосистемы». В ходе этого 
процесса экосистемы воздействуют на ОС, «подгоняют» еe под свои формирующиеся потребности и одновременно остаются в рамках ограничений, налагаемых этой средой. Поэтому для экосистемы важно взаимодействие $c$ окружающей средой, поиск равновесия в определенных ею границах $u$ одновременно воздействие на формирование ОС в соответствии $c$ потребностями жизни, регулирование и воспроизводство внешних условий существования живого [29].

\section{Антропогенные экосистемы и их характеристика}

В 1986 году Ю. Одум разделил существующие экосистемы в зависимости от источника энергии и степени энергетических субсидий на 4 типа, первые из которых природные экосистемы несубсидируемые и субсидируемые естественными источниками и экосистемы субсидируемые человеком (техносфера).

\section{Справка [21]}

1. Природные экосистемы, движимые Солнцем и несубсидируемые (например, открытые океаны, глубокие озера, высокогорные леса). Они получают мало энергии и имеют низкую продуктивность, но при этом занимают основные площади биосферы.

2. Природные экосистемы, движимые Солнцем и субсидируемые другими естественными источниками (например, эстуарии в приливных морях, некоторые дождевые леса, речные экосистемы). Помимо солнечного света они получают дополнительную энергию в виде дождя, ветра, органических веществ, минеральных элементов и т.д.

Экосистемы, движимые Солнцем и субсидируемые человеком (например, агроэкосистемы, аквакультуры). Дополнительная энергия поставляется в них человеком в виде горючего, органических и минеральных удобрений, пестицидов, стимуляторов роста и т. п. Эти экосистемы производят продукты питания и другие материалы.

Примером экосистем, движимыми Солнцем и субсидируемыми человеком, служат агроэкосистемы (сельскохозяйственные экосистемы, агроценозы), т. е. искусственные экосистемы, возникающие в результате сельскохозяйственной деятельности человека (пашни, сенокосы, пастбища). Агроэкосистемы создаются человеком для получения высокой чистой продукции автотрофов (урожая). 
В них также, как в естественных сообществах, имеются продуценты (культурные растения и сорняки), консументы (насекомые, птицы, мыши и т. д.) и редуценты (грибы и бактерии). Обязательным звеном пищевых цепей в агроэкосистемах является человек.

Индустриально-городские экосистемы, движимые топливом (например, города, пригороды, промышленные комплексы). Основным источником энергии служит не Солнце, а топливо. Эти экосистемы зависят от экосистем первых трех типов, паразитируют на них, получая продукты питания и топливо. К индустриально-городским экосистемам относятся урбанистические системы (урбосистемы) - искусственные системы, возникающие в результате развития городов, и представляющие собой средоточие населения, жилых зданий, промышленных, бытовых, культурных объектов и т. д.

В их составе можно выделить следующие территории:

- промышленные зоны, где сосредоточены промышленные объекты различных отраслей хозяйства и являющиеся основными источниками загрязнения OC;

- селитебные зоны (жилые или спальные районы) с жилыми домами, административными зданиями, объектами быта, культуры и т. п.;

- рекреационные зоны, предназначенные для отдыха людей (лесопарки, базы отдыха и т.п.);

- транспортные системы и сооружения, пронизывающие всю городскую систему (автомобильные и железные дороги, метрополитен, заправочные станции, гаражи, аэродромы и т. п.).

Существование урбоэкосистем поддерживается за счет агроэкосистем и энергии горючих ископаемых, атомной промышленности.

Основными общими особенностями системы можно считать следующие:

- система обладает новыми свойствами по сравнению с элементами, из которых она состоит. При этом система - не просто механический набор элементов, а целенаправленное их соединение в виде определенных структур и взаимосвязей; система есть организованное единство элементов, и нарушение 
взаимосвязи приведет к разрушению системы в целом;

- система обладает свойством оптимальности. Любые системы (независимо от их происхождения) проектируются с учетом критериев оптимальности и функционируют согласно построенным заранее оптимальным планам;

- системы создаются для достижения какой-либо цели и решения определенных задач. Не существует систем, не предназначенных ни для чего, не решающих никаких задач. Любая система имеет свое предназначение [17].

В настоящее время можно выделить, по крайней мере, пять типов системных представлений: микроскопическое, функциональное, макроскопическое, иерархическое и процессуальное. Каждое из указанных представлений системы отражает определенную группу ее характеристик [17].

Микроскопическое представление системы основано на понимании ее как множества наблюдаемых и неделимых величин (элементов). Структура системы фиксирует расположение выбранных элементов и их связи.

Под функциональным представлением системы понимается совокупность действий (функций), которые необходимо выполнять для реализации целей функционирования системы.

Макроскопическое представление характеризует систему как единое целое, находящееся в «системном окружении» (среде). Следовательно, система может быть представлена множеством внешних связей со средой.

Иерархическое представление основано на понятии «подсистема» и рассматривает всю систему как совокупность подсистем, связанных иерархически.

Процессуальное представление характеризует состояние системы во времени. Следовательно, система как объект исследования обладает следующими признаками:

- состоит из множества элементов, расположенных иерархически;

- элементы систем (подсистемы) взаимосвязаны посредством прямых и обратных связей;

- система - это единое и неразрывное целое, являющееся целостной системой 
для нижестоящих иерархических уровней;

- наличие фиксированных связей системы с внешней средой.

Для более точного определения понятия система необходимо учитывать такие важные оставляющие любого материального объекта, как элемент, связь, взаимодействие и целеполагание [22].

Элемент - неделимая часть системы, обладающая относительной самостоятельностью по отношению к системе и характеризующаяся конкретными свойствами, определяющими ее в данной системе однозначно.

Связь - совокупность зависимостей свойств одного элемента от свойств других элементов системы. Связь определяется также как ограничение степени свободы элементов системы.

Взаимодействие - совокупность взаимосвязей и взаимоотношений между свойствами элементов, когда они приобретают характер взаимного содействия друг другу.

Целеполагание - определение требуемого состояния или поведения системы.

Причины образования систем являются узловыми в системной теории. Само вовлечение компонентов в систему или выбор их из имеющегося множества происходит до и в процессе формирования цели на основе исходной потребности.

Удовлетворение потребности возможно альтернативными путями. Выбор альтернативного варианта, связанный с оценкой возможностей, определяется выбором определенной и конкретной совокупности методов и средств, обеспечивающих реализацию потребности в данных условиях.

Потребность - то, что объективно связывает живой объект с внешней средой, некоторое (определяющее) условие обеспечения его жизнедеятельности.

Существование систем поддерживается возникновением и удовлетворением потребностей. Для живых систем вообще потребность определяется как «объективно присущие живому организму требования условий, необходимых для его сохранения и развития». Для человека потребности являются «движущей 
силой» поведения и сознания, определенной зависимостью человека от внешнего мира.

Цель системы определяется как вариант удовлетворения исходной потребности, выбранный из некоторого множества альтернатив, сформулированных на основе специального знания. Цель есть конкретное выражение потребности, сформулированное на основе имеющегося опыта и определяющее конкретное функционирование создаваемой системы [29].

Цель - совокупное представление о некоторой модели будущего результата,

способного удовлетворить исходную потребность при имеющихся реальных возможностях, оцененных по результатам опыта.

Наиболее ярким примером системы является живой организм. Элементы (применительно к указанной системе) сами по себе, т. е. вне системы представляют собой нечто другое. Существует известный афоризм: «Нога, отделенная от тела, лишь по названию нога». Связь элементов внутри системы значительно сильнее, чем связь этих же элементов с элементами других систем. Взаимодействие между собой элементов различных систем всегда опосредованно и контролируется взаимодействием самих систем. Основной целью функционирования любого организма является выживание и обеспечение размножения (также способствующего выживанию, но не индивидуальному, a групповому). Функциональную среду живого организма составляет совокупность законов физиологии. Эти законы ограничивают возможную динамику взаимосвязей между элементами организма некоторыми правилами, не позволяющими данным элементам развиваться во вред целому организму. Нарушение функциональной среды вызывает болезнь организма. Элементами системы в рассмотренном примере являются клетки различных органов и тканей организма. Подсистемы, в свою очередь, - это различные органы, состоящие из клеток, основу которых составляют так называемые специализированные клетки, обеспечивающие функционирование данных органов. 
Важным для любой системы и особенностей ее рассмотрения является категория цели. Если рассматривать организм применительно к указанному примеру не как систему, имеющую целью выживание, а как источник пищи для другого организма. Тогда первый организм воспринимается как совокупность белков, жиров и углеводов различной калорийности и питательности. Функциональная среда его будет уже определяться не законами физиологии, а правилами хранения мясных продуктов. При этом если в первом случае разница между здоровым и больным организмом весьма существенна, то во втором - она зачастую вообще не имеет значение [29].

Таким образом, представление об объектах окружающего мира с позиций системного подхода является важным. Такие же закономерности имеют важное значение для определения целей управления безопасностью объектов ОС.

\section{Вопросы и задания для самопроверки}

1. Раскройте содержание понятия «система»

2. Определите содержание процесса управления сложными системами

3. Дайте характеристику эколого-экономической системе

4. Дайте характеристику основных функций системы

5. Определите основные признаки системы

6. Сформулируйте основные условия перехода к устойчивому развитию

\section{Рекомендуемая литература:}

1. Акимова Т. А. Экономика устойчивого развития : учеб/ пособие /Т. А. Акимова, Ю. Н. Мосейкин. М. : Изд-во «Экономика», 2009.

2. Пахомова Н. В. Экономика природопользования и экологический менеджмент. / Н. В. Пахомова, К. К. Рихтер. СПб. : Издательство С.-Петербургского ун-та, 1999.

3. Исаев В. В. Общая теория социально-экономических систем: учеб. пособие. / В. В. Исаев, А. М. Немчин. СПб. : Изд. дом «Бизнес-пресса», 2002.

\section{3. Понятийный аппарат эколого-экономической безопасности}

Проблема безопасности эколого-экономических систем, начиная с конца прошлого столетия, становится одной из важнейших практических проблем развития страны, а также одним из новых междисциплинарных направлений научных исследований. Роль и значение проблемы безопасности в условиях трансформационной экономики обусловлена следующими факторами: 
1) гуманизацией парадигмы мирового общественного развития, поставившей вопрос о необходимости управления безопасностью общества;

2) резко возросшей опасностью техногенных и экологических катастроф в глобальном масштабе;

3) ограниченностью природного капитала;

4) универсальностью понятия «безопасность».

\section{Актуализация проблем безопасности}

В конце 80-х годов практически одновременно зародились две концепции: «Человеческого развития» и «Устойчивого развития» [2]. Активное их развитие пришлось на 90-е годы. Самое деятельное в появлении и формировании этих концепций принимала ООН. Крупнейшие форумы ООН в Рио-де- Жанейро (1992 г.) и Йоханесбурге (2002 г.) были посвящены проблемам и путям перехода человечества к устойчивому развитию. Задача достижения экологической устойчивости была органически включена в глобальную программу развития человека и получила свое отражение в документе «Цели развития тысячелетия», принятом Генеральной ассамблеей ООН в сентябре 2000 г.

Важнейшей общей причиной возникновения и развития концепции человеческого развития и концепции устойчивого развития стало осознание ограниченности и «тупиковости» сложивщейся модели экономического развития. Игнорирование социальных и экологических аспектов развития, определившиеся стереотипь максимизачии стандартов потребления, абсолютизация традиционных экономических показателей, в частности, «рост материального благосостояния» - привели к кризисным явлениям, принявшим в настоящем глобальный характер, и к крайне негативным последствиям, которые в ближайшем будущем создадут угрозу самому существованию человеческой цฺивилизации.

В последнее время из трех факторов экономического роста или трех видов капитала (трудовые ресурсы, физический капитал, природные ресурсы) экологический капитал стал все более лимитировать экономическое развитие. 
Современный тип эколого-экономического развития определяется как техногенный тип экономического развития и имеет следующие характеристики:

- природоемкость (рассматривается как природоразрушающий тип, т. к. осуществляется через быстрое и истощуительное использование невозобновимых видов природных ресурсов);

- использование искусственных средств производства, созданных без учета экологических ограничений;

- сверхэксплуатация возобновимых ресурсов (почва, леса и др.), т. е. со скоростью, превышающей возможности их воспроизводства и восстановления;

- масштабы загрязнения и объемы отходов, превышающие ассимиляциионые возможности ОС;

- множественные отрицуательные экстерналии (внешние эффекты).

При этом до последнего времени вне рассмотрения экономической теории и практики оставались последствия экономического развития (прил. 2, 3) в виде различного рода загрязнений, ущуерба человеческому здоровью, деградации $О C$ (имеются в виду обратные связи между экологической деградацией и хозяйственным развитием, качеством жизни населения и состоянием трудовых ресурсов).

Между тем при формировании стратегий социально-экономического развития необходимо учитывать как минимум три экологических ограничения:

- ограниченные возможности ОС принимать и поглощать, ассимилировать различного рода отходы и загрязнения;

- деградациию возобновимых природных ресурсов в результате чрезмерной эксплуатации (земля, лес, рыбные ресурсы, биоразнообразие);

- конечный характер невозобновимых природных ресурсов (полезные ископаемые, нефть, металлы и др.).

Игнорирование экологических ограничений в угоду техногенному типу развития экономики приводит к глобальным экологическим проблемам, среди которых выделяются следующие: 
- глобальные изменения климата;

- опустынивание (аридизация), обезлесение;

- дефицит сырья;

- истощение озонового слоя, кислотные дожди;

- дефицит пресной воды и загрязнение мирового океана;

- сокращение биоразнообразия и др.

Bblвod

Обострение экологических проблем и рост взаимозависимости всех эколого-экономических процессов на планете явились важнейшей причиной начала разработки конщуепц̧ии устойчивого развития, т.е. мирового развития, учитывающего экологические ограничения и условия безопасного функционирования природных систем

Основные положения концепции были изложены в долгосрочной стратегии развития всемирной системы, разработанной в рамках созданной в 1983 г. Международной комиссией по охране ОС и развитию (МКОСР), и получили поддержку в «Повестке дня XXI века», принятой на конференции ООН в 1992 г. в Рио-де-Жанейро руководителями 178 стран - участниц.

В решениях конференции отмечалось, что проблемы перенаселенности планеты, исчерпания природных невозобновляемых ресурсов, техногенного воздействия на ОС обострены настолько, что дальнейшее развитие человечества прежним путем неприемлемо, поскольку ведет к глобальным экологическим, политическим, демографическим кризисам [45]. Вследствие чего назрела необходимость перехода к устойчивому развитию, при котором удовлетворение жизненных потребностей нынешнего поколения обеспечивается с учетом сохранения подобной возможности для следующих поколений.

Ключевая идея концепции устойчивого развития (УР) состоит в том, чтобы современное общество в своем стремлении к удовлетворению собственных потребностей не наносило необратимого ущฺерба природной 
среде и не обездоливало последующче поколения в отношении необходимьх им жизненных ресурсов.

К началу 90-х гг. сформировались три направления концепцуии устойчивого развития, ориентированные [29] на:

- благосостояние;

- капитал;

- сохранение OC («строгой устойчивости»).

Справка

Характеристика направления «строгой устойчивости» [29]

Наибольшую актуальность и развитие приобрела концепция «строгой устойчивости», для которой характерно разделение благосостояния общества и ОС на экономический и экологический секторы, находящиеся в динамическом равновесии. Согласно концепции «строгой устойчивости» условие, при котором состояние «природного капитала» не должно уменьшаться или должно быть постоянным во времени, является важнейшим.

C точки зрения теории данное требование выполнимо только на основе реализации принципа «разделения», полагающего, что никакое сокращение природного капитала (экологический сектор) невозможно компенсировать каким-либо приростом капитала, созданного человеком (экономический сектор). Очевидно, что постулирование условия длительного поддержания потоков благ, источником которых выступает природный капитал (ограничивающий фактор), вступает в противоречие с основными принципами теории экономического роста, поэтому данный подход в рамках периода 90-х гг. рассматривался как альтернативный неоклассическому и подвергался критике со стороны представителей либерального направления экономической школы.

Однако идея «строгой устойчивости» подверглась нападкам критиков, которые заостряли внимание на том факте, что идея не давала ответа на вопрос о режимах совместимости экономического развития с условием (требованием) природного капитала. Последнее стало основным аргументом в высказываниях об утрате идеей своей практической и прагматической функции. Обвинения в утопичности идеи устойчивого развития, неспособности вписывания цивилизации в биосферу с учетом экологических запретов и ограничений привели к тому, что в концепции выделились два направления взаимодействия природы и общества: «слабой» и «критической» устойчивости. 
Характеристика идеи «слабой устойчивости» [29]

Идея «слабой» устойчивости, подразумевая единство экологического и экономического секторов в целях экологически устойчивого экономического роста, выдвинула требования постоянства уровня агрегированного капитала, то есть природного и созданного человеком, посредством установления границ взаимозаменяемости капиталов (принцип «пределов роста»). Критерием устойчивости общественной системы, согласно требованиям концепции, выступил уровень дохода, определяемый суммой реализуемых возможностей потребления, которые осуществляются без уменьшения его исходного состояния (Дж. Хикс). В соответствии с критерием устойчивое развитие достигается в том случае, если потребление в период $t$ не превышает экологический (социальный) национальный продукт за тот же период.

Идея «критической устойчивости», принимая принцип «пределов роста» направления «строгой устойчивости», в большей степени ориентировала не на пределы роста, а на ограничения, связанные с недопустимым разрушением ОС.

\section{Справка}

Характеристика идеи «критической устойчивости» [29]

В качестве критерия устойчивости выступает минимальный уровень обеспечения системы человеческой жизнедеятельности, отвечающий обязательному условию, согласно которому сокращение какого-либо ресурса ниже уровня минимального запаса не может быть компенсировано «переобеспеченностью» другим ресурсом. Практический аспект реализации идеи «критической устойчивости» заключается в применении прямых мер государственного регулирования, таких как мониторинг и контроль, использования метода диагностики для индикации отклонений фактического состояния от минимального (безопасного) уровня.

Сторонники «критической» устойчивости заняли жесткую позицию в части расширения масштабов экономики, требующей ограничительных пределов в потреблении, т. е. установления определенного экологического коридора, в рамках которого осуществлялся бы процесс экономического развития.

Тем не менее, несмотря на определенную завершенность в концептуальном плане, идея устойчивого развития до настоящего времени 
носит характер теоретических исследований, поскольку для практического применения требуется разработка условий сопоставимости оченки экономического и экологического секторов, критериев и методов расчета показателей устойчивости, критериев и параметров экологических коридоров, обоснования минимального уровня развития эколого-экономических систем.

Другой аспект теории устойчивого развития формировался исследователями, занимающимися проблемами анализа и прогнозирования характеристик сложных систем, к которым относятся и социально - эколого экономические (СЭЭ) системы.

Исследования, выполненные с применением системного подхода к проблематике УР, установили сущность устойчивости как способность системы оставаться относительно неизменной в течение определенного периода вопреки внутренним и внешним возмущуениям, а процесса развития как необратимые качественные изменения системы, сопровождаемые обычно количественными переменами.

В докладе Международной комиссии по окружающей среде и развитию, 1990 г. была сделана попытка подхода к раскрытию сущности устойчивого развития с позиций системы. Последнее привело к введению понятия «социосфера», которая была определена как часть биосферь, преобразованная человеком в цүелях наилучшего соответствия социильно-экономическим потребностям человечества.

Однако приведенное определение ближе к понятию «техносфера» (рис.1) и в большей степени отвечает содержанию, которое было вложено в дефиницию «социосфера» разработчиками доклада. «Экологический энциклопедический словарь» определяет техносферу как часть биосферы, разрушенную и коренным образом преобразованную людьми с помощзью прямого или косвенного воздействия технических и техногенных объектов (здания, дороги, механизмы, предприятия и т. п.) в цзелях наилучшего соответствия сочиально-экономическим потребностям человечества. 


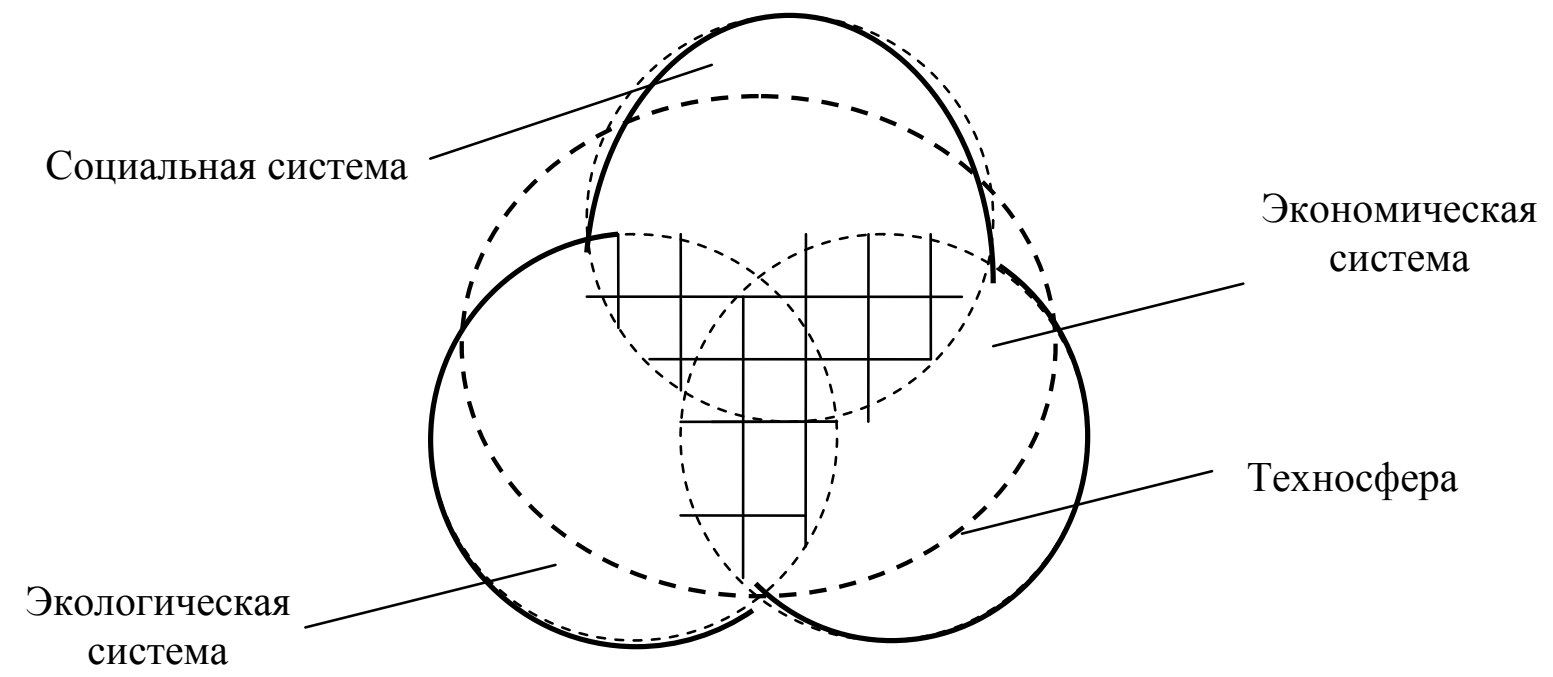

Рис. 1. Эколого-экономическая система регионального уровня

Техносферой занято значительное пространство, принадлежавшее ранее биоте биосферы (несколько тысяч видов растений и животных), впоследствии взятое под контроль человечеством и по существу включенное в состав техносферы [6]. Естественные составляющие биосферы в антропогенной окружающей среде и прежде всего в крупных городах, весьма угнетены (например, растения) или даже отсутствует (большинство животных). Однако отдельные виды живых организмов превосходно приспособились, например, тараканы и крысы-пасюки. Приспособляемость пасюков колоссальна: они превосходно себя чувствуют даже в холодильниках мясокомбинатов при постоянной температуре $\left(-20{ }^{\circ} \mathrm{C}\right)$, в качестве приспособления отращивая длинную шерсть. Домашние животные (собаки, кошки и др.) вынужденно ведут явно ненормальный образ жизни, резко отличный от исходного, природного и др.

Следует признать, что значительная часть современной техносферы - это совершенно новое надприродное образование, генетически не связанное с законами биосферы. В то же время влияние ее на биосферу через эмиссии, потоки вещества, энергии, информации чрезвычайно велико, и им охвачено практически все пространство планеты, при этом экспансия техносферы 
увеличивается год от года. Поэтому созданные человеком в рамках биосферы техническая и социальная цивилизации, могут совместно сосуществовать и развиваться, лишь взаимодействуя с биосферой, не вытесняя и не подавляя ее.

Системный подход обязывает соотносить цุели развития подсистем с цุелями надсистемы (биосфера), потому как иное влечет неизбежность системного кризиса. Следовательно, техносфера и образующие ее подсистемы с точки зрения теории управления должны вписывать свои технологии в биосферные цчикль для сохранения среды обитания человека и основных характеристик природной среды.

На практике человек, стремясь подчинить себе ОС и расширить контуры техносферы, вытесняет биосферу, не учитывая при этом возможные ответные реакции поведения надсистемы (биосферы), которая может и способна устранять варианты развития своих элементов, угрожающих ее самосохранению и нормальному функционированию.

Понимание этой причины нашло отражение в соединении содержания устойчивого развития систем с понятием безопасности данного процесса, что и было озвучено в «Повестке дня ХХІ века».

В контексте документа безопасность рассматривалась как условие функиионирования социальных и природно-технических систем.

Bblвод

Безопасность является неотъемлемым признаком устойчивого развития систем.

Исследуя проблему устойчивого безопасного развития, следует обратить внимание на точку зрения М. А. Лескова. По его мнению, последнее десятилетие, характеризуемое формированием новой концепции безопасности, дает более емкое представление о безопасности как о явлении, тождественном гомеостазису системы, под которым понимается «тип динамичного равновесия, характерного для сложных саморегулирующихся систем, 
состоящего в поддержании сущуественно важных для сохранения системь параметров в допустимых пределах» [25].

В экологических системах устойчивость связывается с гомеостазом, при этом считается, что чем больше система по размеру, тем богаче и разнообразнее ее видовой и популяционный состав.

Масштабные изменения, вызванные природными катастрофами или деятельностью человека, приводят к определенным трансформациям состояния биогеоценозов и к постепенной смене одних сообществ другими (экологическая сукцессия). Те же характеристики устойчивости и изменения состояния действуют применительно к общественным системам. Другими словами, состояние защищенности (предвидения опасности), т. е. способности противостоять дестабилизирующим факторам, должно являться базовым условием формирования сложных систем.

Теория безопасности определяет безопасность в обществе как объективно необходимое социально-экономическое явление и в этом смысле выступает предметом нескольких междисциплинарных направлений общественных $u$ естественных наук, включая экономику и экологию (см. рис. 1).

Содержания категорий экономики, экологии и безопасности, как и других наук, частично пересекаются друг с другом, отчасти взаимоотображая понятия, но специфичность их области знания абсолютно очевидна (рис. 2) и имеет большее значение, чем их общность в объекте исследования: взаимоотношения в системе человек-общество - природа.

Сохранение специфики такой науки, как экономика применительно к новому объекту исследования, каким является безопасность, означает интеграцуию экономики в границыь предмета безопасности и описание ее основных проблем на основе использования экономического подхода.

Методологически это означает отображение основных проблем теории безопасности на основе системы понятий, принципов и методов экономики. 


\begin{tabular}{|c|c|c|c|c|}
\hline \multicolumn{2}{|c|}{ Общая экология } & Экономика & & Безопасность \\
\hline \multicolumn{2}{|c|}{$\downarrow$} & $\downarrow$ & & $\downarrow$ \\
\hline \multicolumn{5}{|c|}{ Прикладной (отраслевой) аспект науки } \\
\hline & $v$ & & & \\
\hline $\begin{array}{c}\text { Экология } \\
\text { промышленная(инженер }\end{array}$ & $\begin{array}{l}\text { Социальная } \\
\text { экология }\end{array}$ & $\begin{array}{c}\text { Экономика промышлен- } \\
\text { ности (отраслей) }\end{array}$ & $\begin{array}{c}\text { Экономика } \\
\text { природопользования }\end{array}$ & $\begin{array}{l}\text { Безопасность сфер } \\
\text { жизнедеятельности }\end{array}$ \\
\hline $\begin{array}{l}\text { Экология канцерогенеза, } \\
\text { и др.областей медицины }\end{array}$ & $\begin{array}{c}\text { Экология } \\
\text { социальных групп }\end{array}$ & $\begin{array}{c}\text { Экономика } \\
\text { предпринимательства }\end{array}$ & $\begin{array}{c}\text { Экономика } \\
\text { природных ресурсов }\end{array}$ & $\begin{array}{c}\text { Социальная } \\
\text { безопасность }\end{array}$ \\
\hline $\begin{array}{c}\text { Экология } \\
\text { географическая }\end{array}$ & $\begin{array}{l}\text { Экология } \\
\text { личности }\end{array}$ & $\begin{array}{l}\text { Экономика } \\
\text { отрасли }\end{array}$ & $\begin{array}{l}\text { Экономическая } \\
\text { безопасность }\end{array}$ & $\begin{array}{l}\text { Экологическая } \\
\text { безопасность }\end{array}$ \\
\hline $\begin{array}{c}\text { Экология химическая } \\
\text { и геохимическая }\end{array}$ & $\begin{array}{c}\text { Экология } \\
\text { человечества }\end{array}$ & Эконометрика & $\begin{array}{l}\text { Экономика } \\
\text { труда }\end{array}$ & $\begin{array}{c}\text { Информационная } \\
\text { безопасность }\end{array}$ \\
\hline $\begin{array}{c}\text { Экология } \\
\text { градостроительная }\end{array}$ & Археоэкология & $\begin{array}{l}\text { Экономическая } \\
\text { кибернетика }\end{array}$ & $\begin{array}{l}\text { Экономика } \\
\text { региона }\end{array}$ & $\begin{array}{l}\text { Демографическая } \\
\text { безопасность }\end{array}$ \\
\hline Биоэкология и др. & Учение о биосфере и др. & $\begin{array}{c}\text { Экономика товарных } \\
\text { рынков }\end{array}$ & $\begin{array}{c}\text { Экономическая } \\
\text { география и } \\
\text { регионалистика и др. }\end{array}$ & $\begin{array}{l}\text { Научно-техническая } \\
\text { безопасность и др. }\end{array}$ \\
\hline
\end{tabular}

Рис. 2. Междисциплинарные направления общественных и естественных наук 
Если объектом исследования экономики становится экология, то в этом случае содержание экономических категорий распространяется и на сферы экологии: природопользование, охрану ОС, социальную экологию.

Справка

Предметной областью общей экологии является «система связей живых и неживых организмов между собой и окружающей средой, сущность которых составляет борьба за условия существования или воспроизводства жизни как таковой», а также законы, описывающие изменение условий, «в рамках и посредством которых может воспроизводиться сама жизнь» [29].

Отношения человека и природы являются предметом исследования многих дисциплин. Однако отличают дисциплины друг от друга не границ̧ь предметной области, а подход. Экономический подход исходит из того, что «условия жизни - есть благо, ограниченный ресурс, входящиий в круг интересов экономического субъекта» [28].

По выражению Роббинса экономика изучает «поведение человека с точки зрения отношений между его целями и ограниченными средствами, допускающими альтернативное использование».

Bblвod

Важным является исследование не изменений, происходящих в качественных параметрах условий жизни (предмет экологии), а оценка человеком ценности экологического блага или отношений между людьми, возникающих по поводу присвоения условий жизни.

Основные общепризнанные свойства (признаки) экономического подхода раскрываются посредством:

- применения функции максимизации полезности или богатства любым субъектом (индивидуумом, хозяйствующим субъектом, государством);

- предположения о наличии особого механизма согласования, максимизирующего поведение всех субъектов общественных отношений; - присутствия характерной черты - стабильности предпочтений. 
При этом следует отметить, что «предпочтения не изменяются скольконибудь существенно с ходом времени и не слишком разнятся у богатых и бедных и даже среди людей, принадлежащих к разным общественным культурам» [29], имея в виду основополагающие объекты человеческого выбора.

Bсе отмеченные самостоятельные дисциплины (см. рис. 2) объединяет общность предметной области - взаимоотношения, возникающие между человеком, обществом и природой, т. е. субъектами общественных отношений, по поводу сохранения и воспроизводства условий жизни, состояния защищенности интересов и условий жизни. Все субъекты общественных отношений вовлекаются в рыночный оборот (механизм формирования экономической ценности блага) и могут рассматриваться как экономические субъекты, для которых можно полагать характерно наличие максимизирующего поведения, то есть применения функции максимизации полезности (богатства).

Bывод

Использование экономического подхода в исследовании проблем экологии и безопасности допустимо и возможно.

Для настоящего периода важным является выделение раздела экономической науки, изучающего проблемы безопасности экологоэкономических систем (эколого-экономической безопасности), нежели построение новой области знания, такой как экономика безопасности.

Теорией безопасности разработано множество критериальных признаков выделения тех или иных видов безопасности. На практике широко распространена классификация безопасности по сферам жизнедеятельности, имеющая тот недостаток, что не фиксирует внимание на причинах возникновения опасности и подчеркивает только ее характер. С точки зрения раскрытия сущностных характеристик безопасности эколого-экономических систем важно, чтобы любая систематизация содержала признаки, выявляющие 
причинно-следственные связи, поэтому целесообразно применяя комплексный подход, выполнить классификацию по совокупности критериальных признаков, акцентируя внимание на группировке по виду воздействия деструктивных сил, т.е. причинах возникновения (рис. 3).

Классификация, включающая источники возникновения опасности, представлены в табл. 3, она выявляет взаимосвязи между видами безопасности и дает возможность понять, что содержание термина «национальная безопасность» не ограничивается защитой от действия coųuальных $u$ политических сил, а заставляет учитывать технические, природные и другие факторы.

Выявлению причинно-следственных связей способствует формирование матрицы влияния, т. к. она отражает общие причины природы угроз и последствия воздействия, как для экономической, так и экологической безопасности (табл. 3). Кроме того, матрица взаимовлияния отражает взаимосвязь экологии и экономики в границах техносферы и обусловливает переход к составлению перечня проблемных эколого-экономических ситуаций (табл. 4).

Таблица 3

Матрица взаимовлияния видов безопасности

\begin{tabular}{|c|c|c|c|c|c|c|c|c|c|c|}
\hline \multirow{3}{*}{$\begin{array}{c}\text { Последствия } \\
\text { воздействия или } \\
\text { угроз }\end{array}$} & \multicolumn{10}{|c|}{ Виды безопасности, выделяемые по признаку } \\
\hline & \multirow{2}{*}{$\begin{array}{l}\text { тип дес- } \\
\text { труктив- } \\
\text { ного воз- } \\
\text { действия }\end{array}$} & \multicolumn{9}{|c|}{ сферы жизнедеятельности* } \\
\hline & & \begin{tabular}{|c|} 
Эко- \\
номи- \\
ческая
\end{tabular} & $\begin{array}{c}\text { Эко- } \\
\text { логи- } \\
\text { ческая }\end{array}$ & $\begin{array}{r}\text { Произ- } \\
\text { водст } \\
\text { свенная }\end{array}$ & $\begin{array}{c}\text { Инвес- } \\
\text { тици- } \\
\text { онная }\end{array}$ & $\begin{array}{l}\text { Научно- } \\
\text { техни- } \\
\text { ческая }\end{array}$ & \begin{tabular}{|c|} 
Со- \\
циаль- \\
ная
\end{tabular} & $\begin{array}{c}\text { Финан- } \\
\text { совая }\end{array}$ & \begin{tabular}{|l|} 
Демо- \\
графи- \\
ческая
\end{tabular} & $\begin{array}{c}\text { Поли- } \\
\text { тичес- } \\
\text { кая }\end{array}$ \\
\hline $\begin{array}{l}\text { Ущерб от воздействия } \\
\text { деструктивных природ- } \\
\text { ных факторов на } \\
\text { общество, производство }\end{array}$ & $\begin{array}{l}\text { Геобио- } \\
\text { физи- } \\
\text { ческий }\end{array}$ & ++ & ++ & + & + & + & + & + & + & - \\
\hline $\begin{array}{l}\text { Ущерб или опасности, } \\
\text { исходящие от современ- } \\
\text { ных технических систем, } \\
\text { производства }\end{array}$ & $\begin{array}{l}\text { Технико- } \\
\text { техноло- } \\
\text { гический }\end{array}$ & ++ & ++ & ++ & + & + & + & + & + & + \\
\hline $\begin{array}{l}\text { Угрозы, вызванные } \\
\text { присущими обществу } \\
\text { противоречиями }\end{array}$ & $\begin{array}{l}\text { Общест- } \\
\text { венный }\end{array}$ & + & + & + & + & + & + & + & + & + \\
\hline
\end{tabular}

* ++ - сильное влияние; + - слабое влияние; - - незначительное 


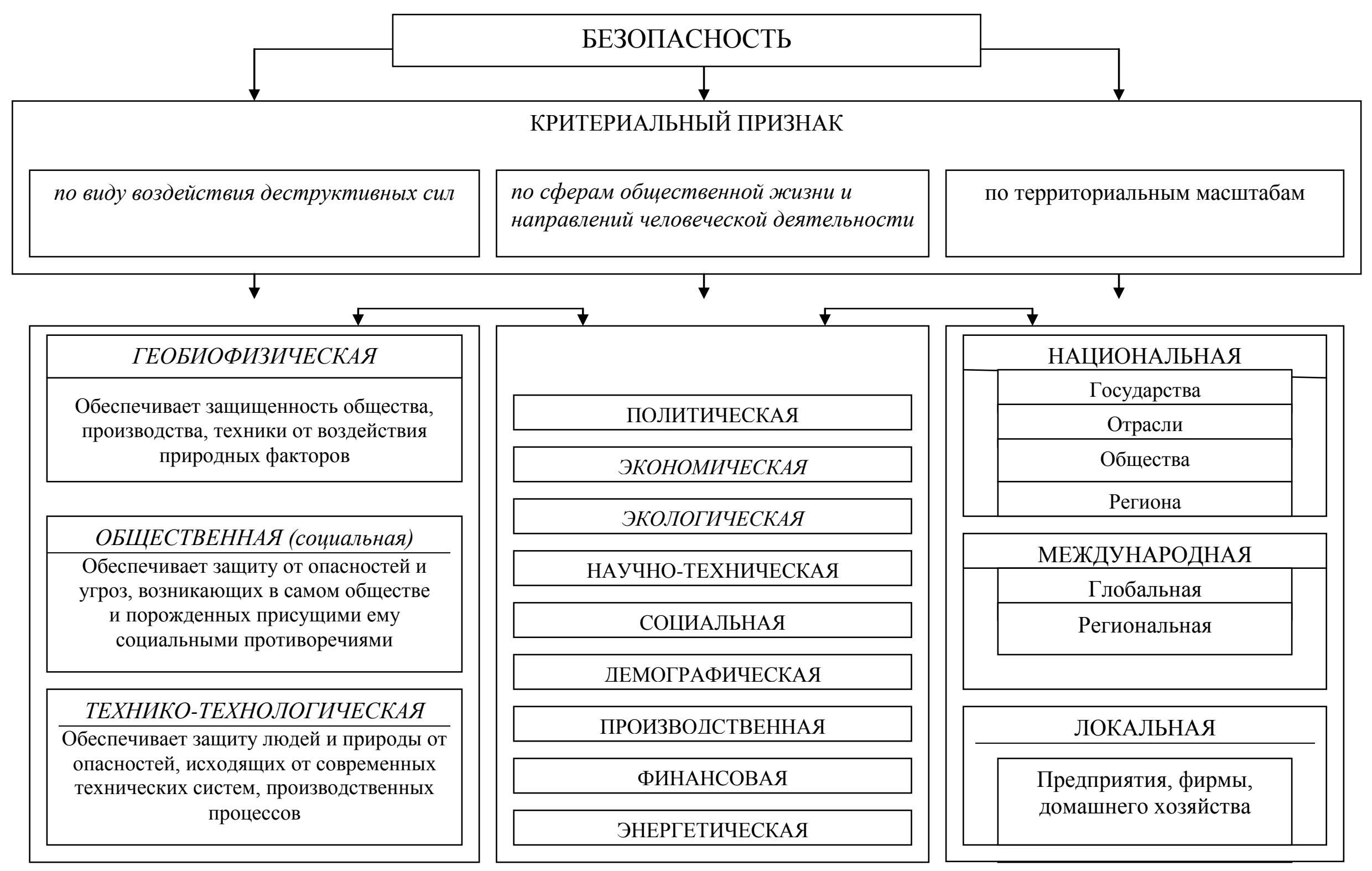

Рис.3. Классификация видов безопасности 
Акцентируя внимание на том, что систематизация по признаку «тип воздействия деструктивных сил» дает возможность ранжировать опасности и устанавливать приоритетные, следует подчеркнуть, характер непостоянства угроз, т. е. изменения в зависимости от конкретной ситуации. Следовательно, в рамках региона эколого-экономические проблемы необходимо ранжировать, выделяя приоритетные (табл. 4).

Таблица 4 Матрица проблемных экологических и экономических ситуаций

\begin{tabular}{|c|c|c|c|}
\hline $\begin{array}{c}\text { Причины } \\
\text { угроз }\end{array}$ & $\begin{array}{c}\text { Безопас } \\
\text { ность }\end{array}$ & $\begin{array}{c}\text { Проблемная } \\
\text { ситуация }\end{array}$ & $\begin{array}{c}\text { Последствия (социальные, экологические, } \\
\text { экономические) }\end{array}$ \\
\hline \multirow[t]{3}{*}{$\begin{array}{l}\text { воздействие } \\
\text { природных } \\
\text { факторов }\end{array}$} & \multirow[t]{3}{*}{$\begin{array}{c}\text { геобио } \\
\text { физичес } \\
\text { кая }\end{array}$} & $\begin{array}{l}\text { Истощение и } \\
\text { сокращение } \\
\text { запасов } \\
\text { природных } \\
\text { ресурсов }\end{array}$ & $\begin{array}{l}\text { Экономические и сочиальные последствия } \\
\text { Прекращение деятельности предприятий- } \\
\text { природопользователей и предприятий местной } \\
\text { промышленности, потеря рабочих мест, снижение } \\
\text { темпов экономического роста и др. }\end{array}$ \\
\hline & & $\begin{array}{c}\text { Ухудшение } \\
\text { качества среды } \\
\text { обитания } \\
\text { человека }\end{array}$ & $\begin{array}{l}\text { Экономические и сочиальные последствия } \\
\text { Повышение заболеваемости, обусловленной } \\
\text { экологическим фактором, рост расходов на } \\
\text { медицинские программы и социальных трансфертов, } \\
\text { потеря рабочих мест, сокращение поступления } \\
\text { налогов в бюджеты всех уровней, изменение } \\
\text { условий проживания и т.д. }\end{array}$ \\
\hline & & $\begin{array}{c}\text { Снижение } \\
\text { качества } \\
\text { хозяйственной } \\
\text { деятельности }\end{array}$ & $\begin{array}{l}\text { Экономические и сочиальные последствия } \\
\text { Сокращение земельных угодий в сельхозобороте, } \\
\text { ухудшение качества потребляемых водных ресурсов, } \\
\text { замедление темпов экономического развития из-за } \\
\text { невозможности размещения новых предприятий и др. }\end{array}$ \\
\hline \multirow[t]{3}{*}{$\begin{array}{c}\text { воздействие } \\
\text { современных } \\
\text { техническихс } \\
\text { истем, } \\
\text { производ- } \\
\text { ственных } \\
\text { процессов }\end{array}$} & \multirow[t]{3}{*}{$\begin{array}{l}\text { технико- } \\
\text { технологи- } \\
\text { ческая }\end{array}$} & $\begin{array}{c}\text { Увеличение } \\
\text { техногенной } \\
\text { нагрузки из-за } \\
\text { развития } \\
\text { дополнительной } \\
\text { инфраструктуры } \\
\end{array}$ & \multirow{3}{*}{$\begin{array}{l}\text { Экологические и экономические последствия } \\
\text { Ухудшение качества окружающей природной среды, } \\
\text { снижение ассимиляционной способности экосисте- } \\
\text { мы территории, ухудшение условий проживания } \\
\text { населения, экономические потери от снижения } \\
\text { темпов объема ВВП, экономический ущерб ОС и } \\
\text { здоровью населения и др. } \\
\text { Экологические и экономические последствия } \\
\text { То же плюс снижение доходов бюджетов от потери } \\
\text { рыночной стоимости территории, ограничение } \\
\text { доступа к биоресурсам и т.д. } \\
\text { Экологические и экономические последствия } \\
\text { Ухудшение качества ОС и условий проживания, } \\
\text { ущерб ОС и здоровью населения, снижение } \\
\text { эффективности производств из-за повышения уровня } \\
\text { издержек на компенсационные выплаты и расходов } \\
\text { на ликвидацию последствий, восстановление и др. }\end{array}$} \\
\hline & & $\begin{array}{c}\text { То же в } \\
\text { результате роста } \\
\text { масштабов } \\
\text { производства } \\
\end{array}$ & \\
\hline & & $\begin{array}{c}\text { Рост числа и } \\
\text { масштабов } \\
\text { техногенных } \\
\text { аварий }\end{array}$ & \\
\hline
\end{tabular}


Bblвodbl

1. Выделение общего круга проблем, свойственных для экологической и экономической безопасности, требует решения исходя из экономического подхода.

2. Признание неразрывности многочисленных проблем экологической и экономической безопасности, имеющих общие причuны природы угроз и последствий (табл. 4), требует eдuнblx рамок предмета изучения.

После определения и обозначения региональных приоритетов, ставятся задачи. Эти задачи формулируются в приложении к конкретным объектам региона и муниципальным образованиям (табл. 5).

Введение сущностных характеристик эколого-экономической безопасности выполняется с учетом представления региона единой экологоэкономической системой, которое формирует определение о нем, как о системе способной сохранять свои базовые свойства при действии комплексных угроз.

Регион определяется как эколого-экономическая система, способная сохранять свои базовые свойства, включая способность противостоять угрозам и дестабилизирующчим факторам, имеющцая общие цчели развития, выраженные особенности хозяйственной структуры, экологической обстановки, соцчиальных приоритетов, обусловленных взаимоотномениями, возникающими при взаимодействии ее подсистем, требующзая единьх форм принятия управленческих решений по экологически обеспеченному экономическому развитию.

Для раскрытия сущности понятия «эколого-экономическая безопасность» предварительно уточним дефиницию «безопасность» (табл. 6), а также объект и задачи теории безопасности (Прил. 1), поскольку анализ дефиниций экономической и экологической безопасности, дает возможность отразить суть каждого понятия на различных уровнях иерархии. 
Цели и задачи безопасности территории

\begin{tabular}{|c|c|c|}
\hline Уровень & Цель & Задачи \\
\hline \multirow{4}{*}{$\begin{array}{l}\text { Терри- } \\
\text { тори- } \\
\text { альная } \\
\text { зона }\end{array}$} & $\begin{array}{l}\text { Выявление кризисных } \\
\text { ситуаций }\end{array}$ & $\begin{array}{l}\text { Выявление территорий, находящихся в } \text { кризисной } \\
\text { ситуации в экономической, экологической и др. сферах }\end{array}$ \\
\hline & $\begin{array}{l}\text { Оценка внешне- } \\
\text { экономических связей }\end{array}$ & $\begin{array}{l}\text { Оценка интенсивности межтерриториальных связей. } \\
\text { Оценка степени и выгоды интеграции территории }\end{array}$ \\
\hline & $\begin{array}{l}\text { Рациональное } \\
\text { природопользование } \\
\text { и экология }\end{array}$ & $\begin{array}{l}\text { Рациональное использование природных ресурсов зоны. } \\
\text { Изучение тенденций состояния экологии. } \\
\text { Формирование перечня городов и территорий со сверх- } \\
\text { нормативными загрязнениями и др. нарушениями ОС }\end{array}$ \\
\hline & $\begin{array}{l}\text { Определение } \\
\text { тенденций } \\
\text { и результатов } \\
\text { экономического } \\
\text { развития }\end{array}$ & $\begin{array}{l}\text { Определение динамики производства и изменений } \\
\text { в структуре хозяйственного комплекса территории. } \\
\text { Определение тенденций в изменении специализации } \\
\text { и территориальном разделении труда. } \\
\text { Выявление проблем экономического характера } \\
\text { для решения которых требуется государственная } \\
\text { поддержка }\end{array}$ \\
\hline \multirow[t]{5}{*}{ Регион } & $\begin{array}{l}\text { Выявление кризисных } \\
\text { ситуаций }\end{array}$ & $\begin{array}{l}\text { Выявление регионов, находящихся в кризисной } \\
\text { ситуации в экономической, экологической и др.сферах } \\
\text { Определение отраслей, подверженных } \\
\text { выявление причин и последствий }\end{array}$ \\
\hline & $\begin{array}{l}\text { Оценка } \\
\text { внешнеэкономических } \\
\text { связей }\end{array}$ & \begin{tabular}{l}
\multicolumn{4}{l}{ Оценка динамики межрегиональных связей } \\
Оценка степени и выгоды интеграции региона \\
в экономику других территорий \\
Определение степени конкурентоспособности \\
производств
\end{tabular} \\
\hline & $\begin{array}{l}\text { Рациональное } \\
\text { природопользование } \\
\text { и экология }\end{array}$ & $\begin{array}{l}\text { Рациональное использование природных ресурсов зоны } \\
\text { Изучение тенденций состояния экологии. } \\
\text { Формирование перечня городов и районов, } \\
\text { характеризующихся сверхнормативными загрязнениями } \\
\text { и др. нарушениями экологического равновесия. } \\
\text { Определить возможности самофинансирования } \\
\text { природоохранных проектов и др. }\end{array}$ \\
\hline & $\begin{array}{l}\text { Определение } \\
\text { тенденций и } \\
\text { результатов } \\
\text { экономического } \\
\text { развития }\end{array}$ & $\begin{array}{l}\text { Определение динамики производства и изменения } \\
\text { в структуре хозяйственного комплекса региона } \\
\text { Определение тенденций в специализации региона, } \\
\text { результативности хозяйственной деятельности } \\
\text { Выявление проблем экономического характера, для } \\
\text { решения которых требуется государственная поддержка }\end{array}$ \\
\hline & $\begin{array}{l}\text { Выявление проблем } \\
\text { социального развития }\end{array}$ & $\begin{array}{l}\text { Оценка изменений в уровне жизни и потреблении } \\
\text { Определение тенденций изменения численности } \\
\text { населения и трудовых ресурсов, выявление причин } \\
\text { Определение тенденций структуры занятости и уровень } \\
\text { безработицы и др. }\end{array}$ \\
\hline
\end{tabular}


Таблица 6

Анализ дефиниций экономической и экологической безопасности

\begin{tabular}{|c|c|c|c|}
\hline Понятие & Содержание & Источник & Комментарии \\
\hline 1 & 2 & 3 & 4 \\
\hline $\begin{array}{l}\text { Эконо- } \\
\text { мическая } \\
\text { безопасно } \\
\text { сть }\end{array}$ & $\begin{array}{l}\text { Совокупность условий } \\
\text { и факторов, обеспечи- } \\
\text { вающих независимость } \\
\text { национальной эконо- } \\
\text { мики, ее стабильность и } \\
\text { устойчивость, способ- } \\
\text { ность к воспроизводству } \\
\text { и развитию }\end{array}$ & $\begin{array}{l}\text { Абалкин Л. И. Избран-С } \\
\text { ные труды : } 4 \text { т. Т. IV. Вс } \\
\text { поисках новой стратегиич } \\
/ \text { Вольное } \\
\text { номическое обо- общество } \\
\text { России. М. : ОАО «НПО I } \\
\text { «экономика», } 2000 .\end{array}$ & $\begin{array}{l}\text { Определение охватывает всю } \\
\text { специфику понятия экономи- } \\
\text { ческой безопасности и может } \\
\text { использоваться для трактовки } \\
\text { өкономической безопасности } \\
\text { территорий любого уровня: } \\
\text { токальный, региональный или } \\
\text { отраслевой и микроуровень }\end{array}$ \\
\hline $\begin{array}{l}\text { Экономи- } \\
\text { ческая } \\
\text { безопас- } \\
\text { ность на } \\
\text { уровне } \\
\text { региона }\end{array}$ & 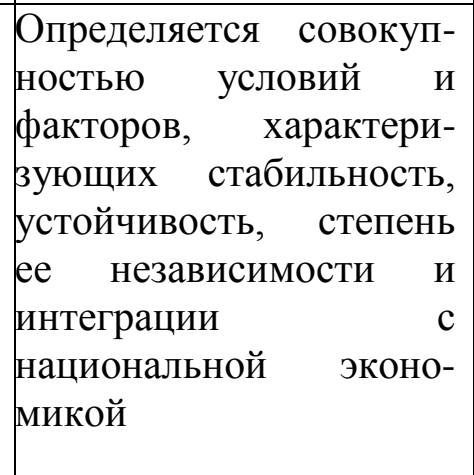 & $\begin{array}{l}\text { Архипов А., Городец- } \\
\text { кий А., Михайлов Б. } \\
\text { Экономическая } \\
\text { безопасность: оценки, } \\
\text { проблемы, способы } \\
\text { обеспечения // Вопросы } \\
\text { Экономики. 1994. № 12. }\end{array}$ & $\begin{array}{l}\text { Подход раскрывает сущность } \\
\text { өкономической безопасности } \\
\text { как политико-экономической } \\
\text { категории, определяемой сис- } \\
\text { гемой экономических отноше- } \\
\text { ний, возникающих между } \\
\text { регионами и центром по } \\
\text { поводу } \\
\text { финансовыми, трудовыми и } \\
\text { природными ресурсами }\end{array}$ \\
\hline $\begin{array}{l}\text { Экономи- } \\
\text { ческая } \\
\text { безопас- } \\
\text { ность } \\
\text { террито- } \\
\text { рий } \\
\text { муници- } \\
\text { пального } \\
\text { уровня }\end{array}$ & 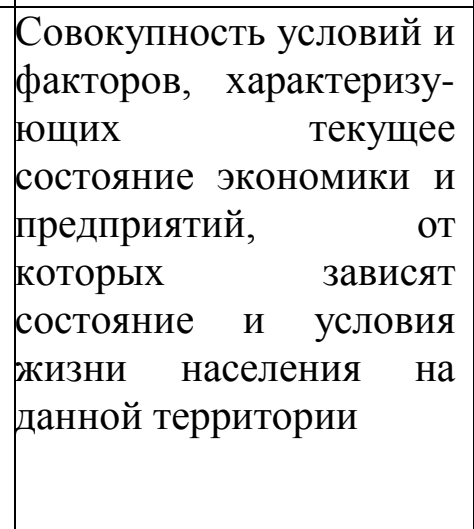 & $\begin{array}{lrr}\text { Бабина Ю. В., Михай- } \\
\text { лова } & \text { Н. } & \text { Д. } \\
\text { Методические подходы } \\
\text { к } \\
\text { субассификации } \\
\text { характев } & \text { РФ } & \text { по } \\
\text { ких проблем длологичес- } \\
\text { госуправления } & \text { целей } \\
\text { Вестник } & \text { Моск. } & \text { ун-та. } \\
\text { сер.6.Экономика. } & 1996 . \\
\text { № 4. } & \end{array}$ & 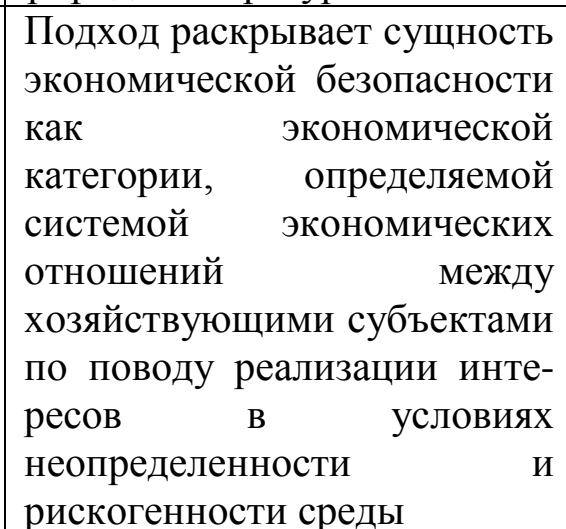 \\
\hline $\begin{array}{l}\text { Экологи- } \\
\text { ческая } \\
\text { безопас- } \\
\text { ность }\end{array}$ & $\begin{array}{l}\text { Защищенность } \\
\text { нейших важ- } \\
\text { личности, } \\
\text { природы, онтересов } \\
\text { создаваемых от угроваз, } \\
\text { генным, естествопо- } \\
\text { воздействием на ОС }\end{array}$ & $\begin{array}{l}\text { Сидорчук В. Л., Давыдо- } \\
\text { ва Р. Т. Экологический } \\
\text { аудит в системе управ- } \\
\text { ления природопользова- } \\
\text { нием: муниципальный } \\
\text { уровень. М. : РЭФИА, } \\
\text { 2001. }\end{array}$ & $\begin{array}{l}\text { Отражает } \quad \text { современные } \\
\text { взгляды на цели, задачи и } \\
\text { механизмы } \\
\text { экологической безоппечения } \\
\end{array}$ \\
\hline $\begin{array}{l}\text { Экологи- } \\
\text { ческая } \\
\text { безопас- } \\
\text { ность }\end{array}$ & 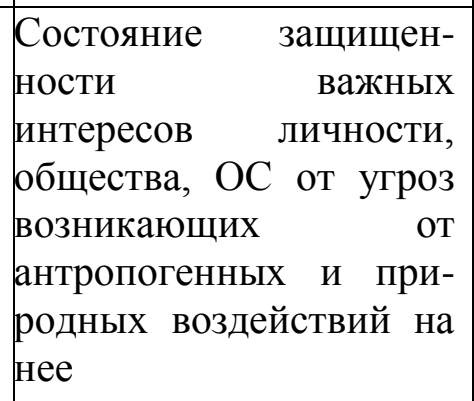 & 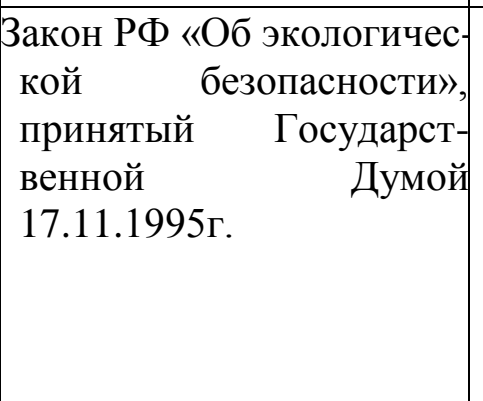 & $\begin{array}{l}\text { Определяет экологическую } \\
\text { безопасность не как процесс, } \\
\text { а как состояние }\end{array}$ \\
\hline
\end{tabular}




\begin{tabular}{|c|c|c|c|}
\hline 1 & 2 & 3 & 4 \\
\hline $\begin{array}{l}\text { Экологи- } \\
\text { ческая } \\
\text { безопас- } \\
\text { ность }\end{array}$ & $\begin{array}{l}\text { Состояние } \\
\text { защищенности ОС и } \\
\text { жизненно важных } \\
\text { интересов человека от } \\
\text { возможного негатив- } \\
\text { ного воздействия } \\
\text { хозяйственной и иной } \\
\text { деятельности, чрезвы- } \\
\text { чайных ситуаций } \\
\text { природного и техно- } \\
\text { генного характера }\end{array}$ & 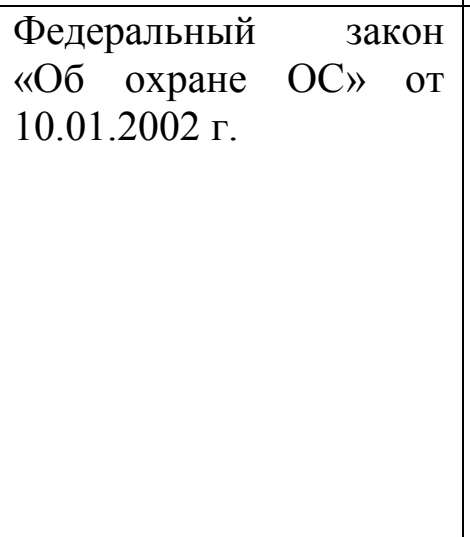 & $\begin{array}{l}\text { Данная трактовка расширяет } \\
\text { понятие экологической } \\
\text { безопасности, так как в ней } \\
\text { рассматриваются послед- } \\
\text { ствия, к которым могут } \\
\text { привести антропогенная } \\
\text { деятельность и чрезвычай- } \\
\text { ные ситуации различного } \\
\text { характера }\end{array}$ \\
\hline $\begin{array}{l}\text { Экологи- } \\
\text { ческая } \\
\text { безопас- } \\
\text { ность }\end{array}$ & 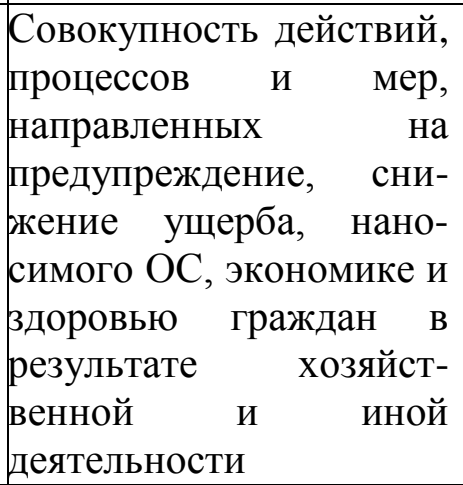 & $\begin{array}{l}\text { И. С. Белик, Н. Л. Нику- } \\
\text { лина. Социально- } \\
\text { экономическое } \\
\text { обоснование } \\
\text { гической безопо- бкности } \\
\text { региона. Екатеринбург: } \\
\text { ИЭ УрО РАН, 2005. }\end{array}$ & $\begin{array}{lr}\text { Понятие } & \text { экологической } \\
\text { безопасности } & \text { позволяет } \\
\text { определить } & \text { направления } \\
\text { воздействия, последствия, к } \\
\text { которым может привести } \\
\text { антропогенная деятельность, } \\
\text { и меры их предотвращения }\end{array}$ \\
\hline
\end{tabular}

В России официальное определение безопасности впервые было сформулировано законом РФ «О безопасности» (от 05.03 .92 г.), трактующим безопасность как состояние защищенности жизненно важных интересов личности, общества и государства от внутренних и внешних угроз. То есть национальная безопасность основывается на триаде: интересы - угрозы (опасности) - защита (обеспечение безопасности).

Под эколого-экономической безопасностью территории понимается состояние защищенности социальных, экономических и экологических интересов личности, общества от угроз, исходящих от действия деструктивных природных сил, технических систем и производств, с характерными для его обеспечения формами и методами предвидения опасных ситуащий, позволяющими выходить из них с наименьшими для природной среды, экономики и здоровья людей последствиями.

Содержание понятия «эколого-экономическая безопасность» (ЭЭБ) дает возможность установить предмет, объект изучения и обозначить 
методологический подход к оценке уровня эколого-экономического состояния региона.

Предметом изучения ЭЭБ территории является совокупность экологоэкономических отношений, возникающая между структурообразующими и хозяйствующими субъектами территории, населением и окружающей природной средой по поводу сохранения ее качественного состояния, реализаџии сощуиально-экономических интересов субъектов и условий жизни населения.

Цель ЭЭБ состоит в развитии эколого-экономических отношений в благоприятных для природы $u$ общества направлениях, обеспечивающих экономическое благополучие, качественные условия жизнедеятельности и состояние здоровья человека.

Эколого-экономическая безопасность решает следующие основные задачи:

- обоснования с учетом экологического фактора экономически сбалансированного размещения производительных сил;

- законодательного закрепления обязательных экологических требований и запрещения организации и ведения хозяйственной деятельности, оказывающей негативное влияние на состояние природной среды (ПС);

- совершенствования системы управления природными ресурсами в рамках соцчиально-экономической политики государства с соответствующим определением необходимых изменений в политике по данным вопросам;

- изучения причин деградации ПС, взаимосвязи социальных, экономических и экологических факторов, оказывающих влияние на этот процесс;

- оценки влияния деградации ПС на развитие ЭЭС;

- снижения уровня техногенной нагрузки на ПС посредством совершенствования экономических методов использования отходов и введения превентивных мер по сокращению эмиссии других загрязняющих веществ;

- разработка прогнозов социально-экономической динамики территории, основанных на критериях безопасного развития; 
- предупреждение развития неблагоприятных эколого-экономических ситуаций в производственной, инвестиционной и других сферах деятельности.

Объектом ЭЭБ являются:

- условия устойчивого, безопасного развития производства, определяемые рамками техноемкости и хозяйственного потенщиала региона;

- условия жизнедеятельности и качество среды обитания человека;

- земля, ее недра, поверхностные и подземные воды, атмосферный воздух, леса и иная растительность, природные ландшафты, используемые в хозяйственной деятельности и включаемые в рыночный оборот;

- различные виды деятельности предприятий-природопользователей, техносфера.

Эколого-экономическое развитие региона - процесс, направленный на поддержание основных параметров ЭЭС в пределах, обеспечивающих развитие, приводящее к качественным изменениям воспроизводства условий жизни и состояния защищенности интересов субъектов, обусловленный действием экономического механизма, основанного на экономических стимулах экологически приемлемого развития.

Методологические подходы к оценке уровня ЭЭБ требуют анализа имеющихся подходов к определению критериев, описывающих состояние и степень экономической и экологической безопасности, уточнения системы показателей, оценивающих уровень безопасности. В этой связи данный вопрос рассматривается как самостоятельный в следующей лекции.

\section{Вопросы и задания для самоконтроля}

1. С какой целью формируется матрица взаимовлияния видов безопасности?

2. Дайте определение понятию «техносфера».

3. С какой целью формируется матрица проблемных экологических и экономических ситуаций?

4. Дайте определение понятию ЭЭБ.

5. Раскройте содержание региона как сложной ЭЭС.

6. Раскройте содержание понятийного аппарата ЭЭБ.

7. Дайте определение понятию «эколого-экономическое развитие региона». 


\section{Рекомендуемая литература}

1. Белик И. С. Оценка и диагностика эколого-экономического безопасного развития территории. Екатеринбург : УГТУ-УПИ, 2008.

2. И. С. Белик Экономические аспекты управления экологической безопасностью региона / под научной редакцией А. А. Куклина. Екатеринбург : Иэ УрО РАН, 2009.

3. Проблемы устойчивого развития социально-экономических ситсем. / А. И. Татаркин, В. В. Криворотов, И. С. Белик [и др.]; под редакцией А.И. Татаркина. Изд-во: Экономика, 2012. $555 \mathrm{c}$.

4. Пахомова Н. В. Экономика природопользования и экологический менеджмент / Н. В. Пахомова, К. К. Рихтер. СПб. : Издательство С.-Петербургского ун-та, 1999. 196 с.

\section{ГЛАВА 2. ОЦЕНКА И ДИАГНОСТИКА ЭКОЛОГО- ЭКОНОМИЧЕСКОЙ БЕЗОПАСНОСТИ РЕГИОНА}

\section{1. Подходы к оценке эколого-экономической безопасности региона}

Применение системного подхода к предмету и объектам ЭЭБ дает возможность выделить базовые свойства ЭЭС, обозначить угрозы, направленные на нее, действующие со стороны деструктивных ПС, современных технических систем и производства и опасности, исходящие от системы (табл. 7). Выявление приоритетных свойств, отвечающих за организацию и устойчивость системы, позволяет раскрыть виды угроз, направленные на изменение важнейших ее свойств, описать последствия воздействия, получаемые в зависимости от характера и степени опасности, установить критерии (характер меры), определяющие безопасность $u$ устойчивость системы (см. табл. 7).

Анализ последствий угроз основным свойствам ЭЭС выявляет существенный факт: первостепенные угрозы по масштабам и тяжести последствий испытывают такие базовые свойства системы, как способность к саморазвитию и способность противостоять дестаблизирующим факторам.

Сущность понятия ЭЭБ раскрывается через определенное состояние защищенности социально-экономических и экологических интересов субъектов. 
Bblвod

Критерием оцуенки уровня безопасности ЭЭС служат критерии, характеризующие базовые свойства.

Данное заключение рассматривается как принциипиальный подход к оценке уровня эколого-экономического состояния, который требует проверки всех природно-технических систем на соответствие способности противостоять дестабилизирующим факторам и способности к саморазвитию. Оценка отмеченных способностей выполняется с использованием критериев «наличие aдаптивных механизмов к внешним воздействиям» и «достаточность ресурсов для простого и расширенного воспроизводства». Рассмотренный подход к оценке ЭЭС не является альтернативным распространенному на практике ресурсному подходу, применяемому для определения уровня экологической безопасности (ЭБ). Он дополняет экологические критерии в подходе к оценке уровня ЭБ, включая элементы среды обитания человека. Именно потому, что многие элементы среды обитания человека используются как ресурс в экономической системе, важно регламентировать их использование с применением экологических критериев.

Ресурсный подход строится на выделении общцих основных количественных характеристик в организации экологических систем, предназначенных для регламентациии региональной хозяйственной деятельности.

К количественным характеристикам ЭЭБ относятся следующие экологические нормативы: экологическая емкость и резерв, техноемкость. В рамках подхода устойчивость территориальных экосистем связывается с величиной экологического резервуара, определяемого как разность между характеристиками, выражающими качество еe текущего и «предельно допустимого» состояния. 
Влияние угроз на базовые свойства ЭЭС

\begin{tabular}{|c|c|c|c|}
\hline Свойства & Критерии & Виды угроз базовым свойствам & Последствия \\
\hline $\begin{array}{l}\text { Способнос } \\
\text { ть } \\
\text { к само- } \\
\text { развитию }\end{array}$ & $\begin{array}{l}\text { Доста- } \\
\text { точность } \\
\text { ресурсов } \\
\text { для прос- } \\
\text { того } \\
\text { и рас- } \\
\text { ширенного } \\
\text { воспроиз- } \\
\text { водства }\end{array}$ & $\begin{array}{l}\text { Истощение природных ресурсов. Нера- } \\
\text { циональное использование невозобно- } \\
\text { вляемых и возобновляемых природных } \\
\text { ресурсов. Высокая изношенность ос- } \\
\text { новных фондов, в т.ч. природоохранно- } \\
\text { го оборудования и сооружений. Не-- } \\
\text { совершенство законодательной базы и } \\
\text { экономического механизма природо- } \\
\text { охранной деятельности и природополь- } \\
\text { зования. Чрезвычайные ситуации при- } \\
\text { родного происхождения. Рост объема } \\
\text { использования природных ресурсов. }\end{array}$ & 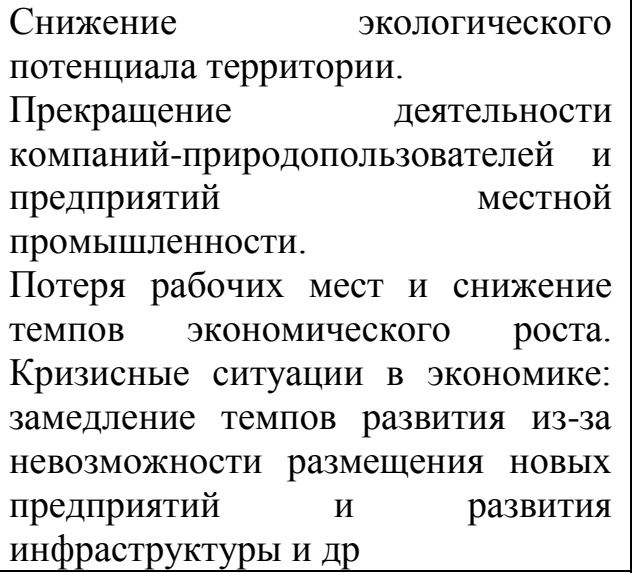 \\
\hline $\begin{array}{l}\text { Способнос } \\
\text { ть } \\
\text { противо- } \\
\text { стоять } \\
\text { дестабили- } \\
\text { зируюшим } \\
\text { факторам }\end{array}$ & $\begin{array}{l}\text { Наличие } \\
\text { адаптив- } \\
\text { ных меха- } \\
\text { низмов к } \\
\text { внешним } \\
\text { воздей- } \\
\text { ствиям }\end{array}$ & $\begin{array}{l}\text { Снижение резерва экологической ем- } \\
\text { кости, техноемкости и ассимиляции- } \\
\text { онного потенциала территории. } \\
\text { Ошибки экспертных исследований при } \\
\text { расширении техносферы и } \\
\text { неудовлетворительная прогнози- } \\
\text { руемость стихийных бедствий } \\
\text { природного характера. Увеличение } \\
\text { антропогенной нагрузки и др. }\end{array}$ & $\begin{array}{l}\text { Экономический } \\
\text { загрязнения ущерб оС, зт } \\
\text { населения. Появление зон бедствия } \\
\text { из-за утраты ПС свойства } \\
\text { самовосстановления. } \\
\text { «Давление» общества на природу, } \\
\text { превосходящее ее возможности, } \\
\text { рост экологических издержек и } \\
\text { неэффективность экономики. Рост } \\
\text { издержек на восстановление и } \\
\text { компенсацию. Проявления } \\
\text { техногенеза на глобальном уровне }\end{array}$ \\
\hline $\begin{array}{l}\text { Способ- } \\
\text { ность обес } \\
\text { печивать } \\
\text { взаимодей } \\
\text { ствие. } \\
\text { Целост } \\
\text { ность } \\
\text { системы } \\
\end{array}$ & $\begin{array}{l}\text { Наличие } \\
\text { сбаланси- } \\
\text { рованного } \\
\text { развития } \\
\text { всех } \\
\text { подсистем }\end{array}$ & $\begin{array}{l}\text { Использование экологически несов- } \\
\text { местимых со средой обитания техноло- } \\
\text { гий и технических средств. } \\
\text { Нарушение естественного равновесия } \\
\text { природных систем. Вовлечение в } \\
\text { рыночный оборот общественных } \\
\text { экологических благ }\end{array}$ & 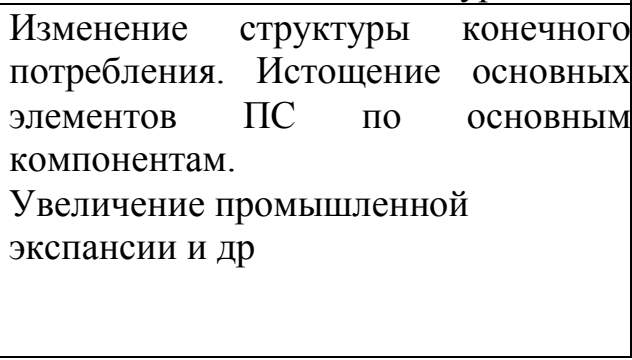 \\
\hline
\end{tabular}

Другими словами, уровень экологического качества территории оцени-

вается степенью соответствия текущуего состояния принятым стандартам $u$ способностью выдержать антропогенную нагрузку, восстановить утраченное свойство или перейти в новое качественное состояние, удовлетворяющее условиям стабильности природно-хозяйственного сообщества.

Справка [2]

Ресурсный подход не развивает такие важнейшие экологические нормативы, как экологическая емкость (ЭЕ), техноемкость (ТЕ), предельно допустимая техногенная нагрузка (ПДТН), которые законодательно до настоящего времени не утверждены как нормативы. Хотя теория и практика определения уровня антропогенной нагрузки и экологической безопасности на основе ресурсного подхода ориентирует на экологические ограничения, не допускающие дестабилизирующего воздействия на ОС. 
Другой подход - индикативный, предложенный Организацией по экономическому сотрудничеству и развитию (ОЭСР), используемый с целью оценки качества ОС и уровня экологической безопасности, основан на применении индикаторов и индексов (рис. 4), которые структурированы по основным сферам жизнедеятельности и элементам природной среды.

Индикативно-индексный подход дополнительно используется для определения последствий человеческого воздействия на ОС и описания состояния экосистем.

В первую группу входят индикаторы «воздействия», характеризующие антропогенную нагрузку, использование природных ресурсов, их динамику.

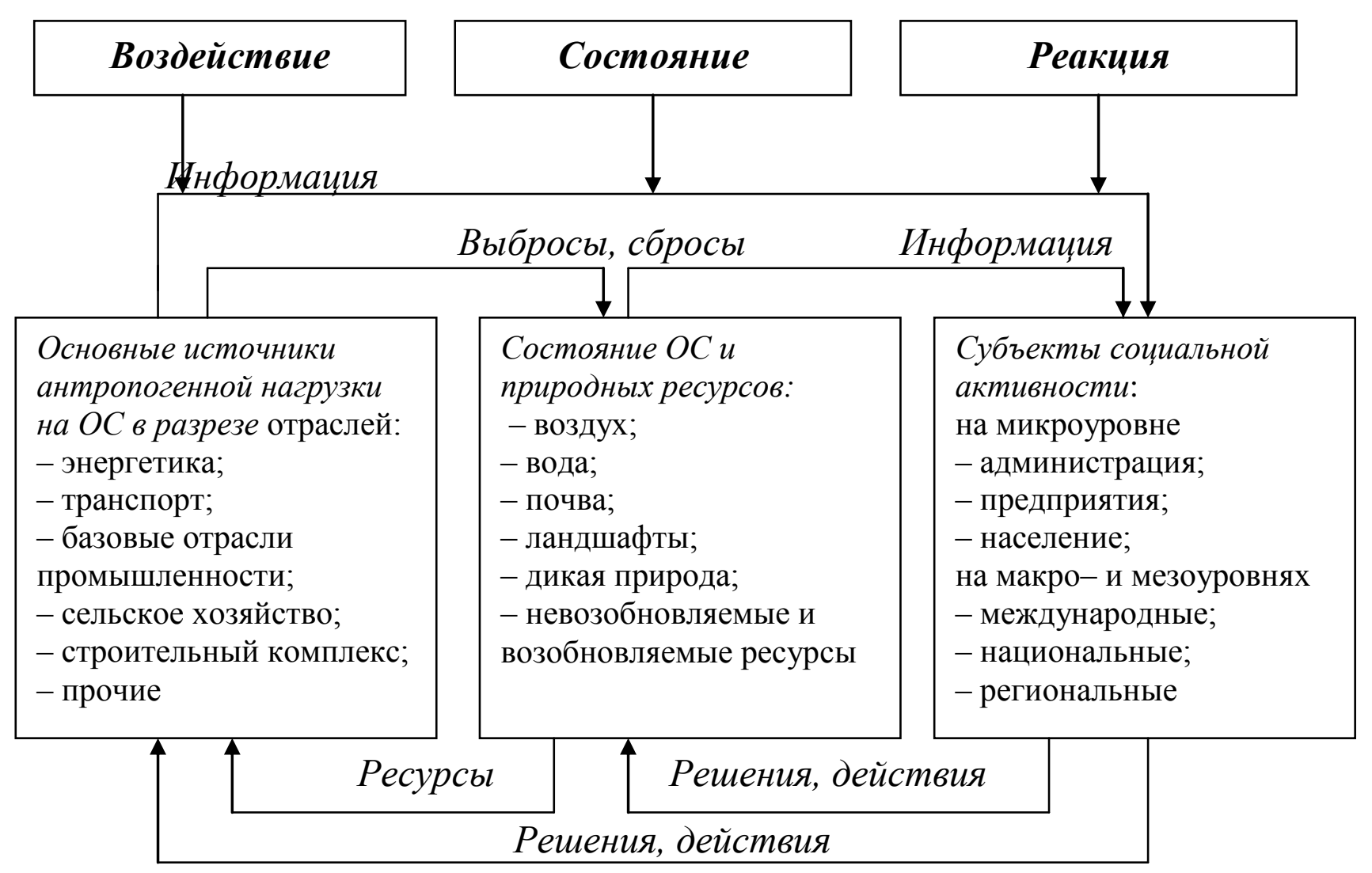

Рис. 4. Основные положения модели «воздействие - состояние - реакция» [8]

Вторую группу формируют индикаторы «состояния», описывающие качество ОС, количественный и качественный уровни запасов природных ресурсов. 
Третья группа включает индикаторы «реакиии», отражающие реакиию общества на изменение состояния ОС - предотвращение или смягчение негативных последствий, адаптаџию к ним, компенсаџию ранее нанесенного ущерба, охрану девственных лесов и др.

Преимущества индикативно-индексного подхода состоят в том, что он допускает высокий уровень агрегации показателей и использования их в сводной форме для территориального и межстранового сравнения уровня техногенной нагрузки и состояния ОС.

Проанализированные подходы к оценке ЭЭБ позволяют сделать следующий вывод.

\section{Bblвod}

Ресурсный и индикативно-индексный подходы в специфичной области показателей могут быть успешно использованы для определения уровня экологической безопасности, не имеющей до настоящего времени окончательно сформированной и рекомендуемой к применению системы оценок.

Однако для определения уровня ЭЭБ и оценки степени дестабилизации OC, устойчивости основных элементов ОС важно привлечение таких агрегатных показателей как техноемкость ПС, экологическая емкость территории, ассимиляционный потенциал, которые соответствуют концепции устойчивого развития и критериям безопасности.

Действующие природоохранные механизмы, созданные в 80-х гг. для регулирования антропогенного воздействия на природные комплексы, менее всего опирались на идеологию устойчивого развития. Для них важнейшими параметрами, принятыми в качестве нормативов, были количественные оценки границ воздействия на природные комплексы, не превышение которых гарантировало безопасные условия жизнедеятельности (в качестве базы использовались показатели критической экологической нагрузки). 
Включение в систему оценки ЭЭБ показателей, которые характеризуют степень дестабилизации ОС (техноемкость, экологическая емкость, рис. 5) позволяют объективно установить порог способности к антропогенному воздействию, и восстановить утраченное свойство (или перейти в новое качественное состояние).

Попытки оценки экологической емкости, ассимиляционного потенциала, техноемкости территории были немногочисленны, поэтому до настоящего времени эти параметры не имеют статуса законодательно утвержденного норматива. Только в начале 80 -х г., появилась методика оценки экологической емкости и техноемкости территории Т. А. Акимовой и В. В. Хаскина [2]. В методике [2] комплексность оценки ЭЭС связывалась с использованием показателей экологической емкости и техноемкости.

Схема комплексной оценки охватывает три модуля, результаты которых агрегируются в сводный показатель (табл. 8).

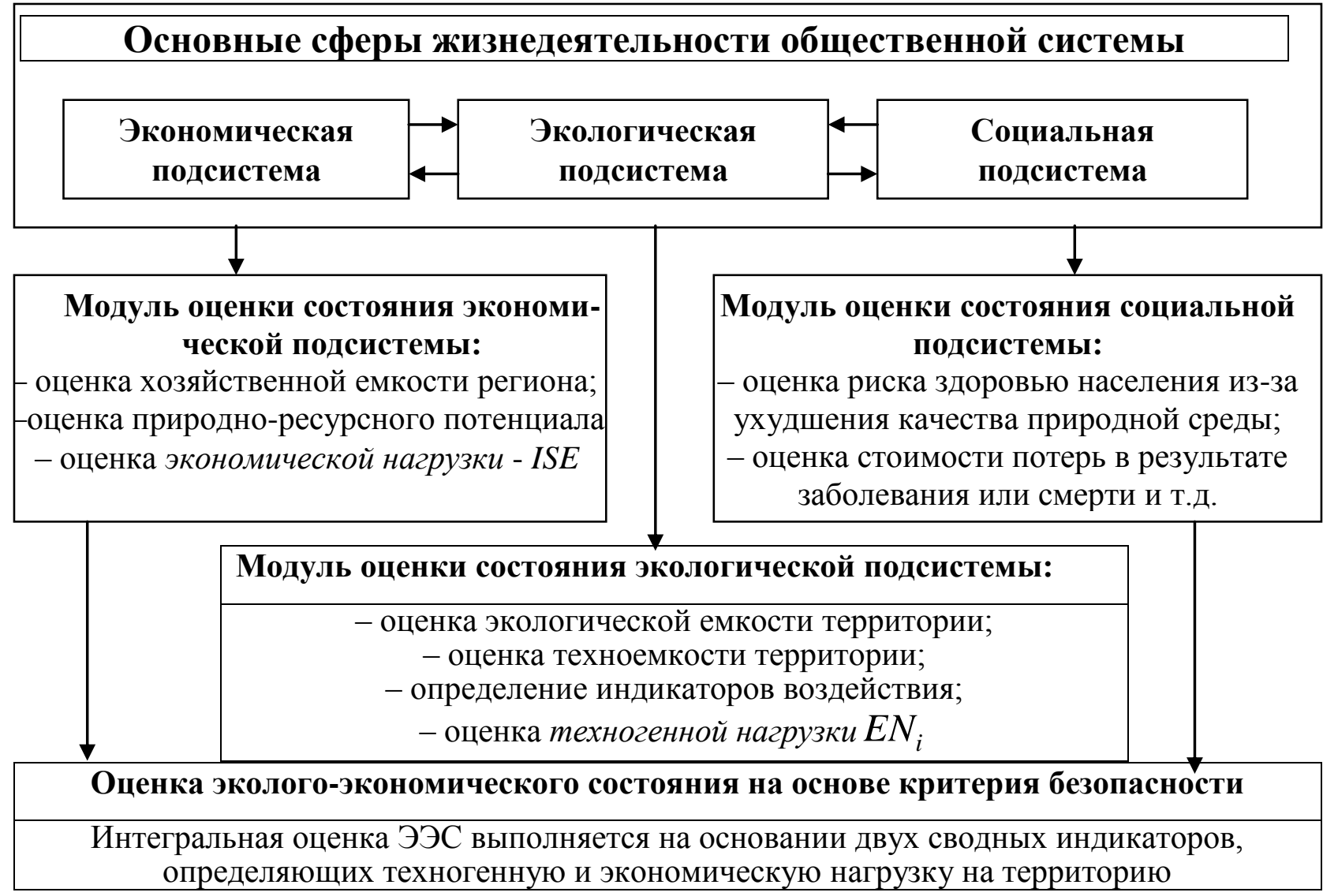

Рис. 5. Схема процедуры оценки эколого-экономической безопасности региона 
Показатели модулей объединяются в соответствии с выделенными критериями достаточности ресурсов для расширенного воспроизводства $u$ наличия адаптивных механизмов к внешним воздействиям (см. табл. 8).

Обоснованием параметров экологической емкости и техноемкости как характеристик устойчивости хозяйственного и природно-ресурсного потенциалов территории служат следующие моменты:

- параметр «экологическая емкость территории» качественно сопоставим с параметром, применяемым для оценки уровня устойчивости территории, т. е. хозяйственной емкостью;

Таблица 8 Критерии оценки эколого-экономической безопасности региона

\begin{tabular}{|c|c|c|c|}
\hline Показатели & Формула & Содержание & Примечание \\
\hline $\begin{array}{l}\text { Индикатор } \\
\text { экономи- } \\
\text { ческой } \\
\text { нагрузки } \\
(I S E)\end{array}$ & $I S E=N K / E P$ & $\begin{array}{l}\text { Характеризует «истоще- } \\
\text { ние» критического капи- } \\
\text { тала по природным ре- } \\
\text { сурсам и основным } \\
\text { характеристикам ПС } \\
\text { (экологически значи- } \\
\text { мым субстанциям кон- } \\
\text { кретной среды), проис- } \\
\text { ходящее в результате } \\
\text { расширения хозяйст- } \\
\text { венной деятельности }\end{array}$ & $\begin{array}{l}\text { где } N K \text {-«критический» капитал } \\
\text { (часть природного капитала, вклю- } \\
\text { чает запасы минерально-сырьевых, } \\
\text { природных ресурсов, участвующих } \\
\text { в ассимиляции), тыс. руб; } \\
E P \text { - хозяйственный потенциал, } \\
\text { опре-деляемый величиной } \\
\text { максимально возможного выпуска } \\
\text { продукции,услуг (Q), производимых } \\
\text { в регионе при имеющихся } \\
\text { технологиях добычи и переработки } \\
\text { ресурсов, тыс. руб. }\end{array}$ \\
\hline $\begin{array}{l}\text { Частный } \\
\text { индикатор } \\
\text { техноген- } \\
\text { ной } \\
\text { нагрузки } \\
i \text {-й } \\
\text { природ- } \\
\text { ной среды }\end{array}$ & $E N=\frac{1}{3} \sum_{i=1}^{3} \frac{T e_{i}}{U i}$ & $\begin{array}{lr}\text { Общий } & \text { индикатор } \\
\text { позволяет } & \text { определить } \\
\text { опасность } \text { самовос- } \\
\text { становительному потен- } \\
\text { циалу территории от } \\
\text { снижения } \\
\text { техноемкости при росте } \\
\text { техногенной нагрузки }\end{array}$ & 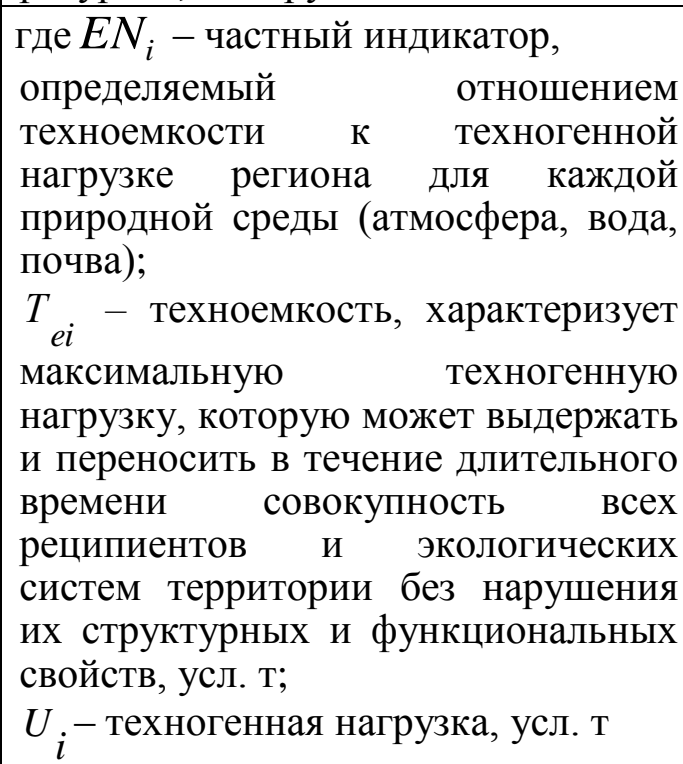 \\
\hline \begin{tabular}{|l} 
Интеграль- \\
ный \\
индикатор
\end{tabular} & $E E S=\sqrt{E N \cdot I S E}$ & $\begin{array}{l}\text { Характеризует эколого- } \\
\text { экономическое } \\
\text { состояние региона }\end{array}$ & $\begin{array}{l}\text { где } E E S \text { - интегральный индикатор; } \\
E N-\text { индикатор техногенной } \\
\text { нагрузки в агрегатной форме; } \\
I S E-\text { индикатор экономической } \\
\text { нагрузки }\end{array}$ \\
\hline
\end{tabular}


- соизмерение природного потенциала и хозяйственной емкости регламентирует эколого-экономическое развитие территории;

- оба параметра отвечают свойствам устойчивости и саморазвития и критериями достаточности ресурсов для расширенного воспроизводства и наличия адаптивных механизмов к внешним воздействиям.

В этой связи уровень эколого-экономической безопасности оценивается с помощью системы показателей, отвечающих за характеристику устойчивого и безопасного развития.

Методологический подход к оценке эколого-экономической безопасности c использованием агрегированных показателей емкости территории, техноемкости, экологической и хозяйственной емкости вкратце сводятся к следующим положениям.

1. Критерий «емкость территории» определяет степень способности какого - либо окружения поддерживать функции некого биотического образования, включая индивида, группы индивидов.

Справка [2]

По мнению Т. А. Акимовой и В. В. Хаскина, экологическая емкость территории «как природного комплекса определяется, во-первых, объемами основных природных резервуаров (воздушный бассейн, водоемы, земельные площади, запасы почв, биомасса флоры и фауны), во-вторых, мощуностью потоков биогеохимического круговорота, обновляющих содержимое этих резервуаров (скорость массо- и газообмена, пополнение объемов чистой воды, процессы почвообразования, продуктивность биоты)». В рамках данного определения решение проблемы расчета экологической емкости территории сводится к установлению основных функций состояния экосистем и изменчивости экологически значимых параметров.

Экологическая емкость сравнивается с величиной экологической и биологической продуктивности территории и рассчитывается по формуле [2]

$$
E_{i}=V_{i} \cdot C_{i} \cdot F_{i}
$$

где $V_{i}$ - объем поверхностных водотоков или площадь земной поверхности, измеряемые соответственно в км³ или км²;

$C_{i}$ - содержание главных экологически значимых субстанций в данной среде, измеряемое в т/км ${ }^{2}$ или т/км ${ }^{3}$; для биомассы C - это плотность поверхностного распределения биомассы территории, т/км²; 
$F_{i}-$ скорость кратного обновления объема воды или биомассы, год ${ }^{-1}$

2. Для параметра экологическая техноемкость должно выполняться условие не превышения техногенной нагрузкой самовосстановительного потенциала территории (критерий безопасности).

В научной литературе за понятием «экологическая техноемкость» территории закрепился термин «техноемкость» территории, под которой понимается предельная выносливость по отношению к повреждающим техногенным воздействиям. Израэль Ю. А., давая оценку экологической техноемкости территории, определил ее как максимальную вместимость количества загрязняющих веществ (3В), поступающих в экосистему за единииу времени, которая может быть разрушена, трансформирована и выведена из пределов экосистемы или депонирована за счет различных прочессов без существенных нарушений динамического равновесия в экосистеме. В исследовании проблемы поиска критериев и количественных характеристик техноемкости территории предпочтительнее точка зрения Т. А. Акимовой и В. В. Хаскина (техноемкость территории представляет часть экологической емкости)

В учебном пособии под «техноемкостью» территории понимается обобщенная характеристика, отражающая самовосстановительный потенциал природной системы и количественно равная максимальной техногенной нагрузке, которую может выдержать и переносить в течение длительного времени совокупность всех реципиентов и экологических систем территории без нарушения их структурных и функциональных свойств.

\section{Справка}

Интерпретация эколого-экономического развития в теории «критической устойчивости» требует строгих ограничений на качество ОС и их сочетания с социальными и экономическими потребностями. Поэтому важно учитывать условие, связанное с неоднородностью природного капитала, его делением на рыночный и нерыночный капитал. Смысловое содержание последнего состоит в том, что для большей части нерыночных активов, составляющих природный капитал, характерна мультифункциональность. Один и тот же ресурс этой группы играет 
независимую роль в восстановлении ПС и имеет самостоятельные экономические, биологические, рекреационныле функиии [29]. Вследствие этого природный капитал, потенциальная деградация которого обратима, может потребляться, исследоваться и оцениваться с использованием традиционных критериев экономической эффективности. Природный капитал, деградация которого необратима или характеризуется высокими масштабами, должен потребляться ограниченно и оцениваться критериями экологической безопасности.

\section{Условия расчета техноемкости}

Определение величины экологической техноемкости территории осуществляется на эмпирически подтвержденном допущении, согласно которому техноемкость составляет часть общей экологической емкости территории и определяется как доля экологической емкости, рассчитанная путем ввода коэффищчиента вариащ̧ии максимальньхх отклонений характеристического состава среды от естественного уровня его колебаний. Превышение этого уровня изменчивости приписывается техногенным воздействиям, достигшим предела устойчивости природного комплекса территории.

Оба параметра (экологическая емкость и техноемкость) рассчитываются в двух формах: в натуральном выражении в виде массы вещества, стандартизованной по опасности (токсичности), и энергетическом выражении. В проблематике, имеющей отношение к оценке ЭЭБ, более приемлемо представление параметров техноемкости и экологической емкости в натуральной форме.

Оценка экологической техноемкости территории, выраженная в единицах массовой техногенной нагрузки, рассчитывается по выражению [2]:

$$
T_{e}=\sum_{i=1}^{3} E_{i} \cdot X_{i} \tau_{i},
$$

где $T_{e}$ - экологическая техноемкость территории, усл. т/год;

$E_{i}-$ экологическая емкость $i$-ой среды, т/год;

$X_{i}-$ коэффициент вариации для естественных колебаний содержания основной субстанции в среде; 
$\tau_{i}$ - коэффициент перевода массы в условные тонны (относительная опасность примесей), усл.т/т. Коэффициент вводится с учетом условия использования «основной субстанции» на нейтрализацию последствий техногенного загрязнения.

Для выполнения положения (2) необходимо определить уровень техногенного воздействия [2]. Показатель «техногенное воздействие» $\left(U_{i}\right)$ вводится для каждой среды, и определяется с использованием следующего выражения:

$$
U_{i}=m_{i}^{t} \cdot K_{e i}
$$

где $m_{i}^{t}-$ приведенная масса загрязняющих веществ, усл. т;

$K_{e \tau}-$ коэффициент относительной эколого-экономической опасности $i$-го загрязняющего вещества или группы веществ.

3. Для оценки «не превышения техногенной нагрузкой самовосстановительного потенциала территории» вводится индикатор, характеризующий уровень безопасности, который показывает степень опасности для природной среды. Это индикатор техногенной нагрузки $\left(E N_{i}\right)$, определяется отношением техноемкости $\left(T_{e i}\right.$, усл. т) к техногенной нагрузке $\left(U_{i}\right.$, усл. т) территории для каждой $i$-й природной среды (атмосфера, вода, почва):

$$
E N_{i}=\frac{T_{e i}}{U_{i}},
$$

или в агрегатной форме как сумма средовых индексов

$$
E N=\frac{1}{3} \sum_{i=1}^{3} \frac{T_{e i}}{U_{i}} .
$$

Привлекательность подхода состоит в возможности соизмерения техноемкости территории и техногенной нагрузки в средовом разрезе, т. е. тестирования основного условия ЭЭБ, согласно которому антропогенное 
воздействие на ОС не должно превышать экологическую техноемкость территории.

Справка

Техноемкость имеет ограничение по нижнему пределу, поэтому с ростом объемов производства и потребления при увеличении антропогенной нагрузки она неизменно снижается, т. к. изменяется ассимиляционная способность ОС, последнее приводит к деградации ОС. Опасность перехода в состояние кризиса (деградации) оценивается с использованием параметров скорости потока поступающих в экосистему $3 B$ за единииу времени, поэтому важнейшими показателями, определяющими состояние ЭЭБ, должны стать приростные характеристики деградации ОС, т. е. $T_{i}=\frac{d T_{i}}{d t}$.

4. Учитывается условие, связанное с неоднородностью природного капитала: рыночный и нерыночный природный капитал, деградация которого необратима или характеризуется высокими масштабами, должен потребляться ограниченно и оцениваться критериями экологической безопасности.

С этой точки зрения следует выделять часть природного капитала, не имеющего замены по функичям, как «критический» природный капитал Соответственно его использование не должно превышать определенные «минимальные нормы сохранения» иначе деградация природной среды примет необратимый характер [28].

Между тем в системе «природа - общество» важно отслеживать и другое соотношение, а именно: соотношение между потоками загрязнений и их совокупным вреднылм эффектом (ущербом), которое зависит не только от массы 3В, но и от продуктивности, и устойчивости экосистем по отношению к техногенным воздействиям, т. е. ассимиляционного потенциала.

Другими словами, действительным ограничителем социальноэкономического развития является ассимиляционный потенциал биосферы. Поэтому, основное уравнение материального баланса между природной и экономическими системами сводится к выполнению соотношения не превышения суммарными отходами ассимиляцуионного потенцииала отдельных экосистем и биосферы в цчелом. 
5. Сохраняется соответствие основным принщипам устойчивости ЭЭС, а именно:

- использование возобновимых природных ресурсов не должно превышать скорости их восстановления;

- поступление загрязняющих веществ не должно перекрывать ассимилящионную способность природной среды.

Увязать экономические и экологические характеристики с условием устойчивости системы возможно посредством использования показателей ассимиляционной способности и биологической продуктивности, в силу того что они одновременно характеризуют техноемкость и хозяйственную емкость территории.

В экономической литературе хозяйственную емкость территории чаще всего обозначают как некий потенциал системы, способный поддерживать производственную функцию, и сравнивают с продуктивностью. Очень часто хозяйственную емкость территории рассматривают как возможность расширения хозяйственной деятельности на данной площади без крупных дополнительных затрат на ее обустройство, главным образом путем интенсификации, комплексного использования освоенных ресурсов (энергосбережение, использование отходов и др.) или с дополнительными затратами на обустройство и вовлечение в хозяйственное использование новых ресурсов [24].

Для определения количественных характеристик показателя емкости вводится следующая формулировка понятия «хозяйственная емкость».

Под хозяйственной емкостью территории понимается обобщенная характеристика ее хозяйственного и природно-ресурсного потенциала, необходимого для реализаџии эффективной экономической деятельности (выпуска продукции, работ, услуг), осуществляемой на основе расширенного воспроизводства при условии сохранения требуемого уровня природной среды .

Другими словами «хозяйственная емкость» характеризует потенщиал саморазвития ЭЭС и способность ее к самосохранению. 
Хозяйственный потенциал $(E P)$ в стоимостном выражении определяется через величину, оценивающую максимально возможный выпуск продукции, работ, услуг производимых на конкретной территории при имеющихся технологиях добычи и переработки ресурсов $(Q)$.

6. Формируется индикатор, соизмеряющий природно-ресурсный и хозяйственный потенциалы, который оценивает степень экономической нагрузки на природную подсистему (индикатор экономической нагрузки - ISE):

$$
I S E=N K / E P .
$$

Показатель характеризует истощение «критического» природного капитала по запасам минерально-сырьевых ресурсов и экологически значимым субстанциям конкретных сред. С приближением к единице достигает предельного значения.

Индекс экономической нагрузки обладает аналитическими возможностями и может использоваться для целей мониторинга уровня эколого-экономического развития при условии его представления в виде приростной характеристики, т. е. скорости изменения показателя. В этом случае снижение индекса прироста ISE свидетельствует об увеличении объемов производства-потребления при несущественно меняющемся показателе $\mathrm{NK}$, и данный факт указывает на повышение производственной функции за счет интенсивных факторов (производительность труда, научно-технический прогресс и др.). Однако удачно складывающаяся экономическая ситуация подъема до конца не снимает угрозу техногенного воздействия на территорию, поскольку состояние экологической безопасности может оставаться напряженным.

Так, например, при увеличении темпов прироста параметра $E P$ над $N K$ индекс ISE будет сигнализировать об ухудшении эколого-экономической ситуации, связанной с увеличением или нерациональным использованием ресурсов и, следовательно, ростом техногенной нагрузки на территорию. 
7. Выполняется оценка ЭЭБ территории (рис. 5) с использованием интегрального индикатора, связывающего индикаторы техногенной нагрузки $(E N)$ и экономической нагрузки (ISE):

$$
E E S=\sqrt{E N \cdot I S E} .
$$

Интегральный индикатор $E E S$ оценивает уровень ЭЭБ региона, он также может использоваться для целей мониторинга, но при условии его представления в виде приростной характеристики.

В этом случае интегральный индикатор EES следует выражать с помощью параметров скорости потока, поступающих в экосистему загрязняющих веществ в единицу времени $\left(E E S^{\prime}=\frac{d E E S}{d t}\right)$, при этом необходимо учитывать скорость изменения всех факторов.

Из условия экологического равновесия вытекает, что изменение таких агрегатных параметров, как природный критический капитал и техноемкость не должно допускаться и должно быть в краткосрочном периоде незначительным, поскольку иное увеличивает опасность перехода в состояние кризиса. В этой связи параметр $E E S$ рассматривается с помощью параметров скорости потока, поступающих в экосистему загрязняющих веществ в единицу времени.

Использование производной от выражения (7) с введением следующих обозначений $N K^{\prime}=\frac{d N K}{d t}=0, \frac{1}{I_{Q}}=\frac{U^{\prime}}{6 T_{e}^{\prime}} \frac{I S E}{E E S}\left(\sum_{i=1}^{3} \frac{T_{e i}}{U_{i}}\left(\frac{T_{e i}^{\prime}}{T_{e i}}-\frac{U_{i}^{\prime}}{U_{i}}-\frac{E P^{\prime}}{E P}\right)\right)$, приводит к формуле:

$$
E E S^{*}=\varphi \frac{I_{U}}{I_{Q}},
$$

где $E S S^{*}$ - индикатор изменения уровня ЭЭБ;

$I_{Q}$ - индекс объема выпуска продукции, услуг производимых в регионе;

$I_{U}$ - индекс прироста техногенной нагрузки на ОC;

$\varphi$ - постоянное число.

Интегральный индикатор $E E S$ * можно выразить в форме оценочного $(J)$ посредством отношения его текущего значения $\left(E E S{ }_{i}\right)$ к рекомендованному 
$\left(E E{ }^{*}{ }_{n}\right): J=E E{ }^{*}{ }_{i} / E E S_{n}{ }^{*}$. При значении $J<1$ состояние характеризуется как удовлетворительное, а при $J=1$ - ЭЭБ территории приближается к критическому уровню.

Модифицированный показатель $E E S^{*}$ может использоваться на уровне региона для контроля за темпами прироста объемов загрязнения и объемов промышленного производства.

Взаимосвязь между объемами валового регионального продукта и эмиссией загрязняющих веществ, поступающих в основные природные среды, характеризуется эластичностью, показатель, который отражает отношение индекса прироста техногенной нагрузки к индексу прироста объемов производства. В этой связи контролировать степень безопасного экологоэкономического развития на уровне региона можно с использованием показателя соотномения темпов прироста эмиссии $3 B$ и объемов промышленного производства (коэффициент опережения) и прироста эмиссии ЗВ на единииу прироста валового регионального продукта («эластичность загрязнения по объему производства»).

\section{Вопросы и задания для самопроверки}

1. Выделить и охарактеризовать базовые свойства системы.

2. Определить основные виды угроз базовым свойствам.

3. Раскрыть содержание критериев безопасности системы.

4. Дать характеристику основным эколого-экономическим индикаторам, обозначить их недостатки.

5. Раскрыть содержание индикаторов, характеризующих экологическую и экономическую нагрузку на территорию.

6. Дать определение понятиям экологическая емкость, хозяйственная емкость территории.

7. Дать характеристику интегрального индикатора в «статике и динамике».

\section{Рекомендуемая литература}

1. Акимова Т. А. Экономика Природы и Человека / Т. А. Акимова, М. Хаскин. М. : ЗАО Изд-во Экономика, 2006. 334 с.

2. Белик И. С. Оценка и диагностика эколого-экономического безопасного развития территории / И. С. Белик. Екатеринбург: УГТУ_УПИ, 2008.

3. Белик И.С. Влияние эколого-экономической безопасности на выбор стратегических инвестиционных решений / И.С. Белик. Екатеринбург : УГТУ-УПИ, 2008. 117с.

4. Пахомова Н. В. Экономика природопользования и экологический менеджмент / Н. В. Пахомова, К. К. Рихтер. СПб. : Изд-во С.-Петербургского ун-та, 1999. 196 с. 


\section{2. Диагностика состояния эколого-экономической безопасности}

Анализ причин угроз и последствий дает возможность сформировать матрицу взаимовлияния видов безопасности (см. табл. 3), что позволяет сделать вывод о возможной количественной оценке влияния ЭЭС на безопасность различных сфер жизнедеятельности. С этой целью выделяются приоритетные сферы жизнедеятельности и виды безопасности (табл. 9).

В список приоритетных сфер жизнедеятельности включены экологическая, производственная, экономическая, научно-техническая, социальная, финансовая и инвестиционная безопасность. Все приоритетные сферы жизнедеятельности обладают собственной системой показателей, определяющих состояние и уровень безопасности, являющихся производными от многих факторов.

Однако в аспекте оценки текущего состояния ЭЭБ рассматривались исключительно показатели, характеризующие интенсивность эксплуатации окружающей среды, изменения экономического качества природной и хозяйственной среды по выделенным приоритетным сферам жизнеобеспечения. Далее выполняется разделение факторов, влияющих на ЭЭБ территории на две группы: факторы состояния и среды. Последующая классификация факторов по иерархии дает возможность установить круг показателей, определяющих состояние и динамику их изменения. Кроме того, в ходе классификации показатели дополнительно разделяются на общие и частные.

В соответствии с выводом показатели, характеризующие состояние безопасности выделенных сфер, должны тестироваться на соответствие критерию «изменение экономического качества природной и хозяйственной среды» (рис. 6). 
Таблица 9

Список показателей, характеризующих состояние безопасности основных сфер жизнедеятельности

\begin{tabular}{|c|c|}
\hline $\begin{array}{c}\text { Виды } \\
\text { безопасности* }\end{array}$ & Показатели состояния безопасности сфер жизнедеятельности \\
\hline 1 & 2 \\
\hline \multirow{9}{*}{$\begin{array}{l}\text { Экономическая } \\
\text { безопасность }\end{array}$} & Объем ВВП (ВРП) на душу населения от среднемирового уровня \\
\hline & Уровень падения промышленного производства \\
\hline & $\begin{array}{l}\text { Удельный вес промышленной продукции предприятий- } \\
\text { природопользователей в общем объеме ВВП (ВРП) }\end{array}$ \\
\hline & $\begin{array}{l}\text { Соотношение темпов производства добывающих отраслей и объемов } \\
\text { промышленного производства }\end{array}$ \\
\hline & $\begin{array}{l}\text { Сокращение запасов природных ресурсов, используемых в } \\
\text { хозяйственной деятельности }\end{array}$ \\
\hline & Показатели, характеризующие изменение инфраструктуры территории \\
\hline & $\begin{array}{l}\text { Соотношение темпов роста индексов цен на минерально-сырьевые } \\
\text { ресурсы и потребительские товары }\end{array}$ \\
\hline & $\begin{array}{l}\text { Материало- и энергоемкость ВВП (ВРП) в сравнении со странами } \\
\text { «большой восьмерки» }\end{array}$ \\
\hline & Изменение текущих затрат на 1 рубль товарной продукции \\
\hline \multirow[t]{8}{*}{$\begin{array}{l}\text { Производственная } \\
\text { безопасность }\end{array}$} & $\begin{array}{l}\text { Отношение прироста запасов полезных ископаемых к объемам } \\
\text { погашения запасов в недрах по основным видам полезных ископаемых }\end{array}$ \\
\hline & $\begin{array}{l}\text { Основные производственные фонды природоохранного назначения в } \\
\text { доле общих основных производственных фондов (ОПФ) }\end{array}$ \\
\hline & Коэффициент обновления ОПФ природоохранного назначения \\
\hline & $\begin{array}{l}\text { Темпы роста потребления водных и минеральных ресурсов на } \\
\text { производственные цели }\end{array}$ \\
\hline & Показатели динамики отходоемкости производства \\
\hline & $\begin{array}{l}\text { Соответствие отечественной продукции мировым экологическим } \\
\text { стандартам }\end{array}$ \\
\hline & $\begin{array}{l}\text { Показатели динамики ресурсоемкости (материало-, энерго-, } \\
\text { топливоемкости) }\end{array}$ \\
\hline & $\begin{array}{l}\text { Доля эксплуатационных затрат на охрану ОС (ООС) в общих } \\
\text { производственных издержках }\end{array}$ \\
\hline \multirow{5}{*}{$\begin{array}{l}\text { Социальная } \\
\text { безопасность }\end{array}$} & Индикаторы динамики денежных доходов населения \\
\hline & $\begin{array}{l}\text { Темпы роста расходов населения на лечение на территориях с } \\
\text { экологически неблагополучной ситуацией в общих расходах регионов на } \\
\text { эти цели }\end{array}$ \\
\hline & $\begin{array}{l}\text { Доля продовольствия, поступившего по импорту, в общем объеме } \\
\text { продовольственных ресурсов }\end{array}$ \\
\hline & Темпы прироста населения в экологически неблагополучных регионах \\
\hline & Соответствие качества питьевой воды нормативам \\
\hline
\end{tabular}


Продолжение табл. 9

\begin{tabular}{|c|c|}
\hline 1 & 2 \\
\hline & $\begin{array}{l}\text { Соответствие качества продуктов питания санитарно-гигиеническим } \\
\text { нормативам }\end{array}$ \\
\hline & Уровень заболеваемости, определенный экологическим фактором \\
\hline & $\begin{array}{l}\text { Уровень смертности, обусловленный экологическим фактором } \\
\text { (в общей смертности) }\end{array}$ \\
\hline & Уровень рождаемости на экологически неблагополучных территориях. \\
\hline \multirow{4}{*}{$\begin{array}{l}\text { Научно- } \\
\text { техническая } \\
\text { безопасность }\end{array}$} & $\begin{array}{l}\text { Число инновационно-активных предприятий в добывающей отрасли по } \\
\text { отношению ко всем отраслям промышленности }\end{array}$ \\
\hline & $\begin{array}{l}\text { Доля затрат на исследования и разработки в области экологии и приро- } \\
\text { допользования в общем объеме затрат на НИР }\end{array}$ \\
\hline & $\begin{array}{l}\text { Доля экспорта научно-технической продукции экологического } \\
\text { профиля в общем объеме экспорта }\end{array}$ \\
\hline & $\begin{array}{l}\text { Отношение стоимости экологически чистого оборудования, } \\
\text { технологий к общей стоимости научно-технической продукции }\end{array}$ \\
\hline \multirow{9}{*}{$\begin{array}{l}\text { Финансовая и } \\
\text { инвестиционная } \\
\text { безопасность }\end{array}$} & Темпы роста инвестиций в основной капитал \\
\hline & Темпы роста инвестиций в геологоразведочные работы \\
\hline & Доля природоохранных инвестиций в общем объеме инвестиций \\
\hline & $\begin{array}{l}\text { Доля инвестиций в энерго- и ресурсосберегающие проекты в общем } \\
\text { объеме инвестиций }\end{array}$ \\
\hline & $\begin{array}{l}\text { Доля бюджетных и внебюджетных средств, направляемых на } \\
\text { финансирование природоохранных проектов и т. д. }\end{array}$ \\
\hline & $\begin{array}{l}\text { Доля в доходах консолидированного бюджета платежей за пользование } \\
\text { природными ресурсами }\end{array}$ \\
\hline & Расходы на охрану ОС в расходах бюджета \\
\hline & Инвестиционные затраты на охрану ОС в ВРП \\
\hline & Суммарные поступления от экологических платежей в \% от ВВП \\
\hline \multirow{7}{*}{$\begin{array}{l}\text { Экологическая } \\
\text { безопасность }\end{array}$} & Темпы роста объемов выбросов, сбросов, размещения отходов \\
\hline & $\begin{array}{l}\text { Темпы прироста удельных объемов выбросов, сбросов, размещения } \\
\text { отходов в расчете на объем промышленного производства }\end{array}$ \\
\hline & $\begin{array}{l}\text { Уровень техногенного воздействия на основные элементы ОПС } \\
\text { (интенсивность использования, показатели изменения состояния ) }\end{array}$ \\
\hline & Доля нарушенных земель в сельскохозяйственном обороте \\
\hline & Суммарные природоохранные затраты на экологию \\
\hline & Экологические потери в \% к ВВП \\
\hline & Сокращение площади биоценозов, лесов и т. д. \\
\hline
\end{tabular}

*Перечень допускает замену показателей, характеризующих одновременно отдельные аспекты безопасности других сфер жизнедеятельности и ЭЭБ при изменении внешних обстоятельств. 


\begin{tabular}{|c|c|c|c|}
\hline \multicolumn{4}{|c|}{$\mathbf{u}$} \\
\hline \multirow{2}{*}{\multicolumn{2}{|c|}{\begin{tabular}{l}
\multicolumn{2}{c|}{ Факторы состояния } \\
Природно- и производственно-заданные факторы, \\
обусловливающие $\quad$ эколого-экономическое \\
развитие территории
\end{tabular}}} & \multicolumn{2}{|c|}{ Факторы с } \\
\hline & & \multicolumn{2}{|c|}{$\begin{array}{llr}\text { Исторически } & \text { сложившиеся } & \text { условия } \\
\text { жизнедеятельности, социально-культурная } & \text { среда, } \\
\text { инновационно-инвестиционная среда }\end{array}$} \\
\hline $\begin{array}{l}\text { Пока- } \\
\text { за- } \\
\text { тели }\end{array}$ & $\begin{array}{l}\text { Экологическая емкость, техноемкость, сум- } \\
\text { марная техногенная нагрузка, природно-ре- } \\
\text { сурсный потенциал, хозяйственная емкость }\end{array}$ & \multicolumn{2}{|c|}{$\begin{array}{l}\text { Культурно-образовательный потенциал, социальная } \\
\text { инфраструктура, инвестиционный и } \quad \text { финансовый } \\
\text { потенциал, правовая среда и т. д. }\end{array}$} \\
\hline \multicolumn{4}{|c|}{ 2-й уровень. Факторы, производные от факторов первого уровня } \\
\hline \multicolumn{2}{|c|}{$\begin{array}{l}\text { Факторы, } \quad \text { определяющие } \\
\text { хозяйственного потенциала: }\end{array}$} & \multicolumn{2}{|c|}{$\begin{array}{l}\text { Факторы, определяющие качество и эффективность } \\
\text { инфраструктуры: }\end{array}$} \\
\hline \multicolumn{2}{|c|}{$\begin{array}{l}\text { уровень техногенногоууровень хозяйственной } \\
\text { воздействия; }\end{array}$} & & эффективность админист- \\
\hline \multicolumn{3}{|c|}{ 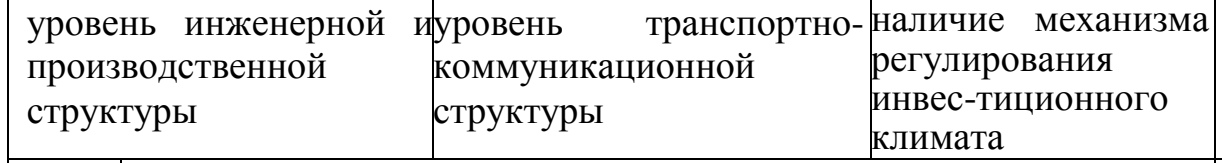 } & $\begin{array}{l}\text { развитость социальної } \\
\text { инфраструктуры, степень } \\
\text { влияния традиций, уклада }\end{array}$ \\
\hline $\begin{array}{l}\text { окка } \\
\text { в- } \\
\text { иели }\end{array}$ & \multicolumn{2}{|c|}{$\begin{array}{l}\text { Доля промышленной продукции предприятий-природополь- } \\
\text { зователей в общем объеме ВРП территории, структурообра- } \\
\text { зующие показатели ВРП; доля основных производственных } \\
\text { фондов природоохранного назначения в общем объеме основ- } \\
\text { ных производственных фондов; уровень техногенного воздей- } \\
\text { ствия на основные элементы ОС; уровень заболеваемости } \\
\text { населения, проживающего на экологически неблагополучных } \\
\text { территорях и др. }\end{array}$} & $\begin{array}{l}\text { Урс } \\
\text { фин } \\
\text { охр } \\
\text { разю } \\
\text { здр } \\
\text { жил } \\
\text { про } \\
\text { нас } \\
\text { обе }\end{array}$ \\
\hline \multicolumn{4}{|c|}{ 3-й уровень. Факторы динамики развития факторов второго уровня } \\
\hline $\begin{array}{l}\text { Тока } \\
\text { за- } \\
\text { пели }\end{array}$ & \multicolumn{2}{|c|}{$\begin{array}{l}\text { Темпы роста потребления минеральных ресурсов на производ- } \\
\text { ственные цели; соотношение темпов производства добывающих } \\
\text { отраслей и объемов промышленного производства; темпы } \\
\text { прироста объемов выбросов, сбросов, размещения отходов; } \\
\text { темпы роста заболеваемости, обусловленной экологическим } \\
\text { фактором, динамика опережения индексов цен на минерально- } \\
\text { сырьевые ресурсы и потребительские товары и др. }\end{array}$} & $\begin{array}{l}\text { фи- } \\
\text { ости } \\
\text { ста }\end{array}$ \\
\hline
\end{tabular}

Рис. 6. Факторы эколого-экономической безопасности региона

\section{Bblвod}

Классификация дает возможность установить, что для оценки изменения уровня эколого-экономической безопасности должны использоваться показатели состояния 3-го уровня.

\section{В результате выполнения этой процедуры был обозначен круг общзих} показателей по рассматриваемым сферам жизнедеятельности. Выбранные 
показатели, названные показателями-представителями, сводятся ассоциативную матрицу (табл.10).

Формирование ассоциативной матрицы позволяет составить максимально емкий перечень показателей, отвечающих за текущее ЭЭС и разделить их в соответствии с критериями безопасности (способность к саморазвитию и способность противостоять дестабилизирующим факторам).

На первых этапах анализа показателей в ассоциативной матрице отмечаются те, которые обладают характеристиками оценки потенциала роста и способностью противостоять деструктивным факторам.

Далее для сужения круга параметров табл. 10, используется метод оценки значимости факторов корреляционно-регрессионного анализа (определяется степень влияния на критериальный показатель - индикатор $E E S^{*}$ ).

В результате сводная оценка ЭЭБ $(S)$ формируется как количественная характеристика частных, но важнейших показателей различных сфер жизнедеятельности :

$$
S=f(Э, \Pi, Э \kappa, И, \mathrm{C}),
$$

где Э - экономическая безопасность;

П - производственная безопасность;

Эк - экологическая безопасность;

И, С - инвестиционная и социальная безопасность.

В итоге в уточненный список показателей-представителей включаются:

- промышленная продукция отраслей-загрязнителей в доле от объема промышленной продукции (ОПП);

- эмиссия загрязняющих веществ, поступающих в основные элементы природной среды (характеристика изменения состояния ПС);

- ОПФ природоохранного назначения, рассчитанные на единицу ОПП;

- эксплуатационные затраты на охрану ОС в расчете на единицу ОПП к затратам на рубль товарной продукции (ТП);

- среднедушевые доходы населения территории, рассчитанные на единицу объема промышленной продукции; 
Таблица 10

Показатели, характеризующие состояние безопасности приоритетных

сфер жизнедеятельности

\begin{tabular}{|c|c|c|c|c|}
\hline \multirow{3}{*}{\begin{tabular}{|c|} 
Сферы \\
жизне- \\
деятель- \\
ности
\end{tabular}} & \multicolumn{4}{|c|}{ Показатели, характеризующие ЭЭБ региона* } \\
\hline & \multicolumn{4}{|c|}{ Свойства } \\
\hline & \multicolumn{2}{|c|}{ способность к саморазвитию } & \multicolumn{2}{|c|}{$\begin{array}{c}\text { способность противостоять } \\
\text { дестабилизирующџи факторам }\end{array}$} \\
\hline $\begin{array}{c}\text { Экономи } \\
\text { ческая }\end{array}$ & \begin{tabular}{|l|} 
Объем промышлен- \\
ной продукиии (ОПП) \\
предприятий-приро- \\
допользователей в \\
доле от ВРП
\end{tabular} & \begin{tabular}{|l|} 
Материало- и \\
энергоемкость ВРП \\
(ОПП) в сравнении со \\
странами «восьмерки»
\end{tabular} & $\begin{array}{l}\text { Соотношение потен- } \\
\text { циальных запасов при- } \\
\text { родных ресурсов, ис- } \\
\text { пользуемых в хозяйст- } \\
\text { венной деятельности } \\
\end{array}$ & $\begin{array}{l}\text { Наличие и степень } \\
\text { износа фондов } \\
\text { природоохранного } \\
\text { назначения }\end{array}$ \\
\hline $\begin{array}{c}\text { Экологи } \\
\text { ческая }\end{array}$ & $\begin{array}{l}\text { Продуктивность } \\
\text { экосистем региона, } \\
\text { биоценозов }\end{array}$ & $\begin{array}{l}\text { Наличие площади сель- } \\
\text { скохозяйственных } \\
\text { земель, лесных угодий }\end{array}$ & $\begin{array}{l}\text { Эмиссия загрязняющих } \\
\text { веществ, поступающих в } \\
\text { элементы ПС }\end{array}$ & $\begin{array}{l}\text { Изменение ассимиляци- } \\
\text { онной способности эко- } \\
\text { систем, техноемкости }\end{array}$ \\
\hline $\begin{array}{c}\text { Про- } \\
\text { извод- } \\
\text { ствен- } \\
\text { ная }\end{array}$ & $\begin{array}{l}\text { Доля эксплуата- } \\
\text { иионных затрат на } \\
\text { ОС в текущих зат- } \\
\text { ратах на производ- } \\
\text { ство продукции }\end{array}$ & $\begin{array}{l}\text { Динамика основных } \\
\text { производственных } \\
\text { рондов природоохран- } \\
\text { ного назначения } \\
\text { рассчитанных на } \\
\text { единичу ОПП }\end{array}$ & $\begin{array}{l}\text { Отношение прироста } \\
\text { запасов полезных иско- } \\
\text { паемых к объемам пога- } \\
\text { шения запасов в недрах } \\
\text { по их важнейшим видам }\end{array}$ & \begin{tabular}{|l} 
Рост потребления \\
водных, минеральных \\
ресурсов на произ- \\
водственные цели; рост \\
отходоемкости
\end{tabular} \\
\hline $\begin{array}{c}\text { Научно- } \\
\text { техни- } \\
\text { ческая } \\
\end{array}$ & $\begin{array}{l}\text { Стоимость } \\
\text { ркологически чистого } \\
\text { оборудования, } \\
\text { технологий в доле от } \\
\text { стоимости научно-тех- } \\
\text { нической продукции } \\
\end{array}$ & $\begin{array}{l}\text { Доля инновационно- } \\
\text { активных предприятий } \\
\text { добывающей отрасли в } \\
\text { целом по промыш- } \\
\text { ленности }\end{array}$ & $\begin{array}{l}\text { Доля экспорта науч-но- } \\
\text { технической продук- } \\
\text { ции экологического } \\
\text { профиля в общем } \\
\text { объеме экспорта }\end{array}$ & $\begin{array}{l}\text { Доля затрат на иссле- } \\
\text { дования в области } \\
\text { экологии и природо- } \\
\text { пользования в объе- } \\
\text { ме затрат на НИР }\end{array}$ \\
\hline $\begin{array}{c}\text { Инвести } \\
\text { цион- } \\
\text { ная }\end{array}$ & \begin{tabular}{|l|} 
Динамика \\
природоохранныхх \\
инвестиций в \\
расчете на ОПП
\end{tabular} & $\begin{array}{l}\text { Динамика инвестиций в } \\
\text { энерго- и ресурсосбере- } \\
\text { гающие проекты в об- } \\
\text { щем объеме инвестиций }\end{array}$ & $\begin{array}{l}\text { Доля бюджетных средств } \\
\text { направляемых на финан- } \\
\text { сирование природоохран } \\
\text { ных проектов }\end{array}$ & $\begin{array}{l}\text { Инвестиции в прог- } \\
\text { раммы, связанные с } \\
\text { изменением климата }\end{array}$ \\
\hline $\begin{array}{l}\text { Финан- } \\
\text { совая }\end{array}$ & $\begin{array}{l}\text { Расходы на охрану } \\
\text { ПС в общих } \\
\text { расходах бюджета }\end{array}$ & $\begin{array}{l}\text { Затраты на охрану } \\
\text { природной среды в доле } \\
\text { от ВРП (ОПП) }\end{array}$ & $\begin{array}{l}\text { Доля в доходах консоли- } \\
\text { дированного бюджета } \\
\text { платежей за пользование } \\
\text { природными ресурсами }\end{array}$ & $\begin{array}{l}\text { Суммарные поступ- } \\
\text { ления от экологи- } \\
\text { ческих платежей в } \\
\text { процентах от ВРП } \\
\end{array}$ \\
\hline $\begin{array}{c}\text { Социаль } \\
\text { ная }\end{array}$ & $\begin{array}{l}\text { Среднедушевые до- } \\
\text { ходы населения в рас- } \\
\text { чете на единииу } \\
\text { ОПП }\end{array}$ & $\begin{array}{l}\text { Рост расходов населения } \\
\text { на лечение в экологичес- } \\
\text { ки неблагополучных зо- } \\
\text { нах }\end{array}$ & $\begin{array}{l}\text { Темпы прироста населе- } \\
\text { ния в экологически не- } \\
\text { благополучных регионах }\end{array}$ & $\begin{array}{l}\text { Уровень заболеваемос- } \\
\text { ти населения от } \\
\text { влияния экологического } \\
\text { фактора ** }\end{array}$ \\
\hline
\end{tabular}

* Курсивом отмечены показатели, отобранных для оценки значимости влияния на безопасное экологоэкономическое состояние региона.

** Показатель строится на основе методов теории риска, поэтому рассматривался отдельно, независимо от влияния на $E E S^{\prime}$.

Принимая во внимание тот факт, что практически по всем выделенным показателям установлены допустимые (рекомендуемые, т. е. среднеотраслевые или нормативные) значения, соответствующие условию устойчивости рассматриваемых сфер жизнедеятельности, можно сделать вывод: взаимосвязь 
ЭЭБ с важнейшими сферами жизнедеятельности дает возможность сформировать область допустимых значений, представляемую частными и сводным индексами.

При этом частный индикатор дает оценку по конкретному состоянию, а сводный - оценку общего состояния.

Сводная оценка, характеризуется как экологически значимая, емкая по степени полноты информации, с периодом охвата - год (или полугодие). По уровню иерархии она относится к региональному уровню и может применяться при принятии хозяйственных решений различных уровней планирования.

Диагностика текущего социального, экономического и экологического положения территории с позиций хозяйственной практики должна содержать в своей структуре диагностику ЭЭС (рис. 7). Результаты диагностики ЭЭБ должны способствовать классификации объектов воздействия хозяйственной деятельности на ОС по степени их опасности. Аппарат диагностики, основанный на использовании индикаторно-индексного метода, обычно выполняется в следующей последовательности:

- определение границ исследования (требования по форме проведения любых статистических наблюдений);

- сбор, сводка (сжатие), упорядочивание информации, полученной от отчетных единиц;

- определение текущих значений описательных индикаторов и индексов;

- введение оценочных индикаторов и индексов и формирование границ их изменения;

- оценка степени отклонения основных контролируемых параметров от установленных граничных или заданных значений;

- оценка степени изменения уровня ЭЭС;

- изменение целей развития или разработка мер, исправляющих сложившуюся ситуацию. 


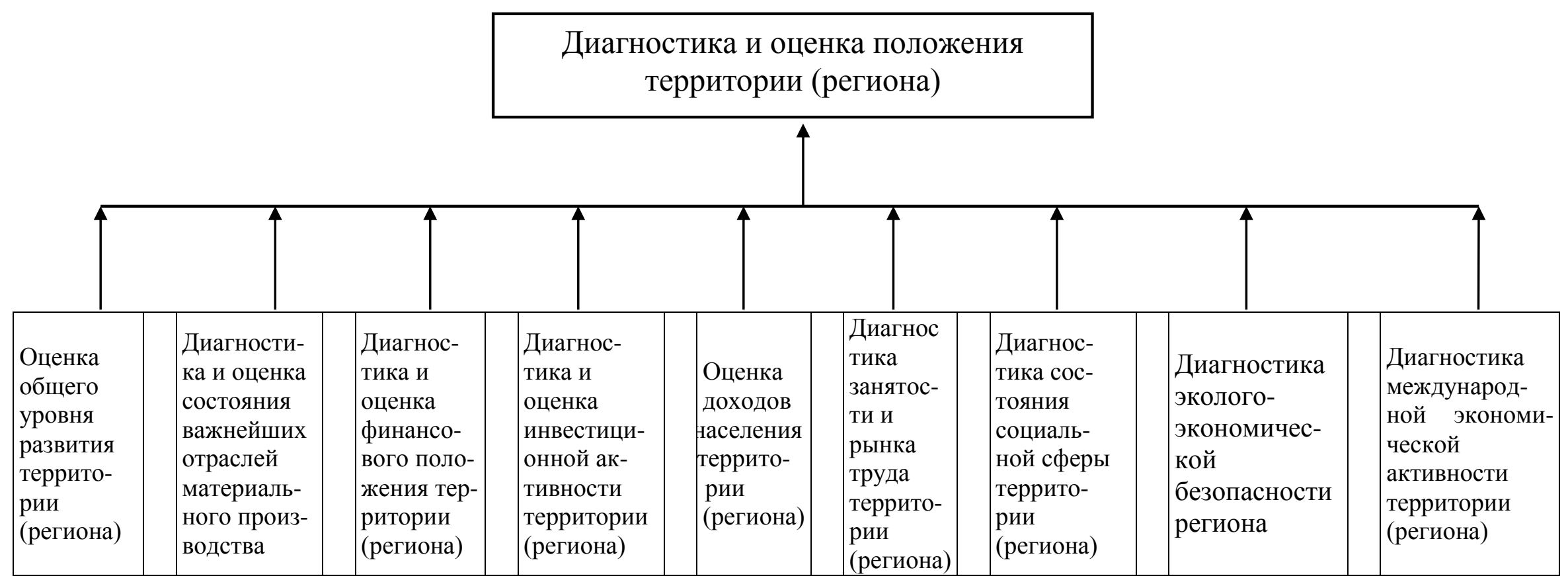

Рис. 7. Схема диагностики и оценки социального и эколого-экономического положения региона [13] 
Собственно процедура диагностики требует отчетливого определения значений описательных и оценочных индикаторов и/или индексов, введения грании их изменения, оценки степени отклонения основных контролируемых параметров от установленных граничных (заданных) значений, на основании которых выполняется оценка состояния и уровня безопасности.

В аспекте определения текущего уровня ЭЭБ рассматривались показатели, характеризующие интенсивность эксплуатации ПС и изменения экономического качества окружающей природной и хозяйственной среды в форме индексов (табл. 11):

- промышленная продукция отраслей - загрязнителей - ОПП;

- масса загрязняющих веществ, поступающая в основные элементы ПС (характеризует изменения состояния 3-х сред);

- основные производственные фонды природоохранного назначения, рассчитанные на единицу ОПП;

- эксплуатационные (текущие) затраты на охрану ОС в расчете на единицу ОПП;

- среднедушевые доходы населения территории в расчете на единицу ОПП.

Индекс роста инвестиций в природоохранную сферу в расчете на единицу ОПП был исключен из перечня рекомендуемых показателей-представителей для диагностирования состояния ЭЭБ из-за слабой его связи с интегральным индикатором EES. Показатель, характеризующий уровень заболеваемости, обусловленный экологическим фактором, в силу методических особенностей его расчета рассматривался отдельно, независимо от степени влияния на $E E S$.

По всем выделенным показателям установлены и/или уже имеются допустимые (приемлемые $x_{i}$ ) значения, соответствующие условию устойчивости рассматриваемых сфер жизнедеятельности, и, следовательно, это доказывает существование области нормируемых оценок ЭЭБ, при которой сохраняется заданное состояние других сфер. 
Таблица 11

Показатели-представители, характеризующие состояние ЭЭБ

\begin{tabular}{|c|c|c|}
\hline Показатель & $\begin{array}{l}\text { Формула } \\
\text { расчета }\end{array}$ & Примечание \\
\hline $\begin{array}{l}\text { 1.Темп роста объема эмиссии 3В: } \\
\text { - в атмосферу (выбросы); } \\
\text { - водные ресурсы (сбросы); } \\
\text { - почву (размещение отходов), \% }\end{array}$ & $J_{M}=\frac{y_{i}}{y_{i-1}} \cdot 100 \%$ & $\begin{array}{c}y_{i}-\text { текущее значение показателя } \\
\text { (выбросы, сбросы, отходы) в } i \text { периоде; } \\
y_{i-1}-\text { предыдущее значение показателя. }\end{array}$ \\
\hline $\begin{array}{l}\text { 2. Темп роста объема } \\
\text { промышленной продукции } \\
\text { предприятий - загрязнителей в } \\
\text { доле от ОПП, \% }\end{array}$ & $J_{\text {ОПП }}=\frac{y_{i}}{y_{i-1}} \cdot 100 \%$ & $\begin{array}{c}y_{i}-\text { текущее значение объема } \\
\text { промышленной продукции в } i \text { периоде; } \\
\quad y_{i-1}-\text { предыдущее значение показателя. }\end{array}$ \\
\hline $\begin{array}{l}\text { 3.Темп роста средних доходов } \\
\text { населения, рассчитанных на } \\
\text { единицу ОПП, \% }\end{array}$ & $J_{\text {Дох }}=\frac{y_{i}}{y_{i-1}} \cdot 100 \%$ & $\begin{array}{l}y_{i}-\text { текущее значение удельных доходов } \\
\text { населения в } i \text { периоде; } \\
y_{i-1}-\text { предыдущее значение показателя. }\end{array}$ \\
\hline $\begin{array}{l}\text { 4. Темп роста основных фондов } \\
\text { природоохранного назначения, } \\
\text { рассчитанных на единицу ОПП, \% }\end{array}$ & $J_{\text {ОПФ }}=\frac{y_{i}}{y_{i-1}} \cdot 100 \%$ & $\begin{array}{c}y_{i}-\text { текущее значение фондов } \\
\text { природоохранного назначения в } i \text { периоде } \\
y_{i-1}-\text { предыдущее значение показателя. }\end{array}$ \\
\hline $\begin{array}{l}\text { 5. Темпы роста эксплуатационных } \\
\text { затрат на охрану ОС к затратам на } \\
1 \text { руб. ТП, \% }\end{array}$ & $J_{Э К C}=\frac{y_{i}}{y_{i-1}} \cdot 100 \%$ & $\begin{array}{l}y_{i}-\text { текущее значение удельных } \\
\text { эксплуатационных затрат в } i \text { периоде; } \\
\quad y_{i-1}-\text { предыдущее значение показателя }\end{array}$ \\
\hline
\end{tabular}

Для отображения области допустимых значений была сформирована матрица области нормализованных значений показателей ЭЭБ. Однако предварительно, согласно порядку построения матриц подобного типа, все отобранные показатели должны дополнительно пройти процедуру соответствия текущеего уровня допустимому (или среднему) по каждому описываемому состоянию. С этой целью формируется шкала оценок влияния. Матрица оценок влияния построена на основе показателей-представителей и их качественных характеристиках. Градуировка шкалы производится с использованием балльной системы оценок (пятиразрядной). Оценки влияния $\left(k_{j}\right)$ устанавливаются на основе шкалы (табл. 12) для определения соответствия полученного количественного значения показателя качественной оценке влияния на состояние ЭЭБ и формирования области допустимых значений по каждому описываемому состоянию. 
Шкала оценок влияния на уровень ЭЭБ

\begin{tabular}{|l|c|c|c|c|c|}
\hline \multicolumn{1}{|c|}{ Показатели-представители } & \multicolumn{5}{|c|}{ Шкала оценки } \\
\cline { 2 - 6 } & 1 & 2 & 3 & 4 & 5 \\
\hline $\begin{array}{l}\text { Темп роста промышленной продукции } \\
\text { отраслей - загрязнителей в доле от ОПП } \\
\text { ВРП) }\end{array}$ & $\begin{array}{c}\text { Очень } \\
\text { высокий }\end{array}$ & Высокий & Средний & Низкий & $\begin{array}{c}\text { Очень } \\
\text { низкий }\end{array}$ \\
\hline $\begin{array}{l}\text { Индекс роста ОПФ природоохранного } \\
\text { назначения, рассчитанного на единицу ОПП }\end{array}$ & $\begin{array}{c}\text { Очень } \\
\text { низкий }\end{array}$ & Низкий & Средний & Высокий & $\begin{array}{c}\text { Очень } \\
\text { высокий }\end{array}$ \\
\hline $\begin{array}{l}\text { Темп роста загрязнения атмосферного } \\
\text { воздуха }\end{array}$ & $\begin{array}{c}\text { Очень } \\
\text { высокий }\end{array}$ & Высокий & Средний & Низкий & $\begin{array}{c}\text { Очень } \\
\text { низкий }\end{array}$ \\
\hline Темп роста загрязнения водных объектов & $\begin{array}{c}\text { Очень } \\
\text { высокий }\end{array}$ & Высокий & Средний & Низкий & $\begin{array}{c}\text { Очень } \\
\text { низкий }\end{array}$ \\
\hline $\begin{array}{l}\text { Темп роста загрязнения почвы (земной } \\
\text { поверхности) }\end{array}$ & $\begin{array}{c}\text { Очень } \\
\text { высокий }\end{array}$ & Высокий & Средний & Низкий & $\begin{array}{c}\text { Очень } \\
\text { низкий }\end{array}$ \\
\hline $\begin{array}{l}\text { Индекс роста затрат эксплуатационных на } \\
\text { охрану ОС в расчете на единицу ОПП к } \\
\text { затрат на 1 руб. ТП }\end{array}$ & $\begin{array}{c}\text { Очень } \\
\text { низкий }\end{array}$ & Низкий & Средний & Высокий & $\begin{array}{c}\text { Очень } \\
\text { высокий }\end{array}$ \\
\hline $\begin{array}{l}\text { Темп роста среднедушевого дохода } \\
\text { населения в расчете на ОПП }\end{array}$ & $\begin{array}{c}\text { Очень } \\
\text { низкий }\end{array}$ & Низкий & Средний & Высокий & $\begin{array}{c}\text { Очень } \\
\text { высокий }\end{array}$ \\
\hline
\end{tabular}

В заключение строится матрица нормализованных значений (табл.13), которая базируется на допустимых значениях параметров, взвешенных на оценки влияния. Согласно процедуре все избранные показатели $\left(x_{i}\right)$ нормируются в зависимости от влияния на ЭЭБ по формуле 10, если снижение значения показателя ведет к ухудшению ее состояния

$$
\bar{x}_{n i}=\frac{x_{i}-x_{\min }}{x_{\max }-x_{\min }}
$$

или по формуле (11), если рост значения показателя ведет к ухудшению

$$
\text { состояния ЭЭБ } \quad \bar{x}_{n i}=1-\frac{x_{i}-x_{\min }}{x_{\max }-x_{\min }} \text {, }
$$

где $x_{i}-$ принятое значение показателя $i$, не нарушающее состояние ЭЭБ; $x_{\max }-$ наибольшее значение показателя, соответствующее нормальному эколого-экономическому состоянию; $x_{\min }-$ наименьшее значение показателя, отвечающее низкому уровню ЭЭБ; 
Таблица 13

Матрица нормализованных значений параметров ЭЭБ

\begin{tabular}{|c|c|c|c|c|c|c|c|c|}
\hline Критерий оценки & $\begin{array}{c}\text { Допусти } \\
\text { мое } \\
\text { значение }\end{array}$ & 1 & 2 & 3 & 4 & 5 & $\begin{array}{l}\text { Норми- } \\
\text { рован- } \\
\text { ное }\end{array}$ & $\begin{array}{l}\text { Взвешен- } \\
\text { ное значе- } \\
\text { ние }\end{array}$ \\
\hline $\begin{array}{l}\text { Темп роста промышленной продукции } \\
\text { отраслей - загрязнителей лей в доле от } \\
\text { ОПП }\left(J_{\text {Oпп }}\right)\end{array}$ & $x_{1}$ & & & & & & $x_{n 1}$ & $\overline{x_{n 1}} \cdot k_{j}$ \\
\hline $\begin{array}{l}\text { Темп роста ОПФ природоохранного } \\
\left.\text { значения в расчете на ОПП ( } J_{\text {оПФ }}\right)\end{array}$ & $x_{2}$ & & & & & & $x_{n 2}$ & $\overline{x_{n 2}} \cdot k_{j}$ \\
\hline $\begin{array}{l}\text { Темп роста объемов загрязнения } \\
\text { атмосферного воздуха }\left(J_{M}{ }_{a m}\right)\end{array}$ & $x_{3}$ & & & & & & $x_{n 3}$ & $\overline{x_{n 3}} \cdot k_{j}$ \\
\hline $\begin{array}{l}\text { Темп роста объемов загрязнения водных } \\
\text { объектов }\left(J_{\text {мсбр }}\right)\end{array}$ & $x_{4}$ & & & & & & $x_{n 4}$ & $\overline{x_{n 4}} \cdot k_{j}$ \\
\hline $\begin{array}{l}\text { Темп роста объемов загрязнения почвы } \\
\left(J_{\text {мпочва }}\right)\end{array}$ & $x_{5}$ & & & & & & $x_{n 5}$ & $\overline{x_{n 5}} \cdot k_{j}$ \\
\hline $\begin{array}{l}\text { Темп роста текущих затрат на охрану ОС } \\
\text { рассчитанных на единицу ОПП к затратам } \\
\text { на } 1 \text { руб ТП }\left(J_{\ni \kappa C}\right)\end{array}$ & $x_{6}$ & & & & & & $x_{n 6}$ & $\overline{x_{n 6}} \cdot k_{j}$ \\
\hline $\begin{array}{l}\text { Темп роста среднедушевых доходов населе- } \\
\left.\text { ния рассчитанных на единицу ОПП ( } J_{\text {дох }}\right)\end{array}$ & $x_{7}$ & & & & & & $x_{n 7}$ & $\overline{x_{n 7}} \cdot k_{j}$ \\
\hline \multicolumn{8}{|l|}{ ИТОГО } & $S$ \\
\hline
\end{tabular}

$i$ - число показателей, включаемых в систему диагностики $(i=1,2, \ldots, n)$.

После нормирования показатели взвешиваются на коэффициент $\left(k_{j}\right)$, оценивающий его значение в баллах $\left(x_{i}=\overline{x_{i}} \cdot k_{j}\right)$.

Результатом формирования матрицы нормализованных значений служит, во-первых, получение комплексной оценки $(S)$, вычисляемой путем суммирования взвешенных на оценки влияния $k_{\mathrm{j}}$ нормированных величин $\left(\bar{x}_{i}\right)$ по формуле

$$
S=\sum \overline{x_{i}} \cdot k_{j}
$$

во-вторых, графическое изображение области допустимых значений.

В итоге матрица нормируемых значений (табл. 13), дает возможность разработать область допустимых значений, не нарушающих состояние безопасности других сфер жизнедеятельности и текущих значений параметров. 
Важнейшим результатом разработки матрицы является возможность получения не только области допустимых оценок, но и возможность нормирования текущих значений показателей и осуществления на этой основе контроля за ЭЭБ, т. е. мониторинга. В этом случае последовательность, предусмотренная порядком формирования матрицы нормализованных допустимых оценок, сохраняется и в соответствии с ней строится матрища текущих значений ЭЭБ.

Расчеты текущих значений параметров выполняются на основе отчетных данных (с применением оценок влияния) и показывают результаты, отражающие фактическое состояние ЭЭБ. Наложение области нормализованных значений, полученной по допустимым (стандартным) оценкам, на область, сформированную по текущим данным, позволяет сравнивать показатели и на этом основании диагностировать уровень экологоэкономической безопасности региона.

Кроме того, методика диагностики состояния ЭЭБ дает возможность получить сводную оценку в форме агрегатного показателя, характеризующего уровень ЭЭБ региона.

Преимуществом методики диагностики является:

- использование показателей, отвечающих критериям сохранения базовых свойств;

- необязательное выделение потенциальных классов состояний в границах, искусственно заданных для ЭЭС;

- возможность применения для территорий разного уровня;

- получения частных и сводной $S$ оценки уровня ЭЭБ.

Оченка допустимого уровня ЭЭБ региона

В соответствие с методикой область допустимых значений параметров строится с учетом наилучшего достигнутого значения показателя по региону или среднероссийского уровня.

Bce показатели-представители в форме индексов (см. табл. 11) подвергаются экспертной оценке (см. табл. 12), которая позволяет сопоставить 
численное значение показателя с качественной оценкой его влияния на ЭЭБ региона и перевести качественную оценку в баллы. Введение процедуры способствует формированию через качественную оценку количественного показателя области допустимых значений. Показатели, оказывающие влияние на эколого-экономическую безопасность, градуируются по пятибалльной шкале, что соответствует следующей линейке измерений (значение показателя в \% - балл), если рост значения показателя улучшает уровень ЭЭБ: 60 - $85 \%$ (1 балл), 85 - 110 \% (2 балла), 110-135 \% (3 балла), 135-160\% (4 балла), $160 \%$ и выше (5 баллов).

Если снижение показателя ухудшает уровень ЭЭБ баллы меняются на противоположные (вместо 5 баллов указывается 1 балл) по той же линейке измерений.

Допустимое значение первых трех индексов (пункт 1, табл. 11), характеризующих рост объемов эмиссии $3 B$ (атмосферный воздух, водные ресурсы, почва), принимаются для Свердловской области исходя из показателей эластичности, которые определяются для каждой среды, подверженной техногенному воздействию, и планируемых темпов прироста ОПП.

Значения эластичности, при которых определена целевая функция, имеют следующую величину: выбросы - 0,41, сбросы - 0,14, размещение твердых отходов - 0,33. При этих значениях, формируемая область допустимых значений ЭЭБ, обеспечивает приемлемый уровень безопасности других сфер жизнедеятельности [14].

Плановая величина прироста объемов промышленного производства составляет 3 \% (данные «Схемы развития и размещения производительных сил Свердловской области на период до 2015 года», [46]). По данным прироста объемов и эластичности рассчитываются значения индексов роста объемов выбросов, сбросов, размещения отходов: 101,2 \%, 100,4 \%, 101,0 \%, соответственно. Данные значения индексов, полученные по средним 
характеристикам эластичности за ряд лет, характеризуют экологическую ситуацию, как напряженную, оцениваемую по шкале влияния на 2 балла.

Дальнейшее превышение допустимого значения диагностируется как понижение уровня ЭЭБ с негативными последствиями перехода в состояние кризиса.

Последующей процедурой оценки ЭЭБ является нормирование показателей. Увеличение индексов роста эмиссии загрязняющих веществ yхудшает ситуацию $\left(\bar{x}_{i}^{\uparrow}\right)$, поэтому нормирование выполняется с использованием формулы (11).

Нормированное значение показателя «взвешивается» на балл с использованием выражения $\left(x_{i}=\overline{x_{i}} \cdot k_{i}\right)$ для получения частной оценки.

Второй показатель - темп роста доли промышленной продукциии отраслей-загрязнителей в доле от ОПП.

Для Свердловской области доля продукции отраслей-загрязнителей в общем объеме ОПП близка к 88 \%. Уровень показателя очень высокий и отличается от среднероссийского, составляющего $55 \%$ [46], в 1,6 раза. Очевидно, что тенденция снижения промышленной продукции отраслейприродопользователей является приоритетной для области.

Средний темп прироста индекса ОПП предприятий-загрязнителей практически всегда положительный. Для Свердловской области за десятилетний период он составил 6,9 \%. При предположении, что в последующие периоды рост регионального продукта будет достигаться за счет роста объемов сферы услуг, торговли, продукции инновационноориентированных отраслей, структура ВРП претерпит изменения в позитивную сторону. В этой связи ежегодные темпы снижения индекса доли продукции природоэксплуатирующих производств должны составлять не менее - 3,3 \%, что даст возможность приблизиться к среднероссийскому уровню за десять лет.

Третий показатель - темп роста средних доходов населения в расчете на единицу ОПП. 
Показатель рассчитан на основе параметра «эластичность доходов по ОПП» и темпов прироста объемов ОПП. За рассматриваемый период выявлена отрицательная тенденция роста среднедушевых доходов (по данным [37]). Эластичность доходов по ОПП, показывает их отставание на 4 \% при росте ОПП (ВРП) на 1 \%. Средний темп роста показателя за 13-летний период составил 97,4 \%, что является крайне негативным фактом. Удельный вес доходов населения в ВРП в России в среднем составляет $18 \%$, что в 2,1 раза ниже доли доходов в стоимости совокупного продукта для стран - участниц ВТО (38 \%). С учетом требований Всемирной торговой организации по уровню доходов в стоимости совокупного продукта обосновывается уровень прироста показателя доходов - 15 \% в год. Однако даже при таком высоком темпе прироста значение показателя (среднедушевые доходы в расчете на единицу ОПП) остается низким, т. е. соответствующим 2 баллам.

Четвертый показатель - темп роста основных фондов природоохранного назначения в расчете на единич ОПП.

Для области абсолютное значение показателя стоимость фондов на единицу продукции составляет 0,08 руб. на 1 рубль промышленной продукции области. Очевидно, что значение показателя очень низкое, особенно, имея в виду, высокую долю продукции отраслей-загрязнителей в общем объеме ОПП (88 \%). К тому же результаты анализа трендов показывают, что темпы прироста индекса отрицательны и для Свердловской области составляют - 0,9\%.

Учитывая складывающиеся тенденции снижения стоимости фондов природоохранного назначения, уровень их износа (по оценкам специалистов составляет более $40 \%$ [37]), факт роста риска аварийных ситуаций (риск возрастает вдвое при изношенности фондов более чем на 50 \%), закладывается увеличение индекса основных производственных фондов в доле от ОПП как минимум в 1,5 раза (допустимое значение). Однако даже в этом случае величина индекса роста остается на низком уровне (2 балла). Принимая значение доли 0,12 руб. / руб. $(0,08 \cdot 1,5)$ в качестве рекомендуемой, заметим, что 
темп прироста индекса должен иметь положительную динамику и равняться минимум 5 \% в год, с тем чтобы через десять лет выйти на заданный уровень. Допустимый уровень показателя определяется в размере $105 \%$.

Нормирование индекса, снижение значений которого ведет к ухудшению ситуации, выполняется по формуле (10).

Частная оценка получается умножением нормированного значения показателя на балл $(k)$ с использованием выражения $\left(x_{i}=\overline{x_{i}} \cdot k_{i}\right)$.

Пятый показатель - индекс эксплуатациионных затрат на охрану ОС в расчете на единицу ОПП к затратам на 1 руб. товарной продукции (ТП).

Сопоставление индексов эксплуатационных затрат на охрану ОС и текущих затрат на рубль ТП за ряд лет свидетельствует об опережающем росте второго показателя, что косвенно указывает на ухудшение качества ОС. Ухудшение уровня ЭЭБ подтверждает факт роста объемов производства, происходящий в основном за счет природоэксплуатирующих отраслей, и неизменности динамики текущих затрат на охрану ОС (эксплуатационные затраты на охрану ОС в расчете на 1 рубль ОПП составляют 0,02 руб. / руб.). Индекс роста удельных затрат на охрану ОС и эксплуатационных затрат на 1 руб. ТП меньше единицы и несущественное положительное изменение прироста этого показателя вызвано в основном движением затрат на рубль ТП, а не ростом эксплуатационных затрат на охрану ОС.

Увеличение доли эксплуатационных затрат на охрану ОС в общих затратах вдвое требует нарастания показателя темпами, превышающими средний темп прироста $(1,7$ \%). Следовательно, учитывая рост объемов производства продукции на 3 \% и допущение о том, что весь прирост будет получен за счет инновационной составляющей, значение индекса роста принимается на уровне 105 \% (прирост 5\%). Полученное значение соотношения затрат по шкале оценок влияния будет соответствовать среднему баллу (3).

Частная оценка формируется с использованием выражения $\left(x_{i}=\overline{x_{i}} \cdot k_{j}\right)$. 
Сводная оценка ЭЭБ, по всем рассматриваемым состояниям, рассчитывается как сумма частных оценок и характеризуется как сводная оценка области приемлемых значений.

Методика диагностики ЭЭБ требует сравнения сводной оценки области приемлемых значений со сводной оценкой текущего состояния ЭЭБ для определения величины отклонения. Сводная оценка текущего состояния формируется на основе отчетных данных по методике, рассмотренной выше.

Отклонения, выявленные в ходе диагностики по каждому состоянию и сводной оценке, анализируются с целью выработки мер по исправлению негативной ситуации. Если отклонение сводной текущей оценки ЭЭБ от допустимого уровня существенное - применяются меры государственного управления в долгосрочном и краткосрочном периодах: например пересматриваются изелевые параметры (темпы роста объемов производства), экологические ограничения (уменьшение неорганизованных выбросов, сбросов, сокращение площадных стоков и др.), вводятся или изменяются экономические регуляторы.

Таким образом, разработка области допустимых значений, выполняемая при диагностике ЭЭБ, позволяет выработать приоритеты в политике охраны ОС и служит инструментом управления эколого-экономическим развитием региона.

Пример

Формирование диагностической картинь ЭЭБ (на примере Свердловской области)

В ходе диагностики, получаемая информация об изменении состояния качества природной среды, дает возможность вскрыть угрозы техногенного характера, негативные последствия реализации хозяйственных решений, оценить степень кризисности территории. Территорией апробации служит Свердловская область (УрФО).

Диагностика ЭЭБ Свердловской области, проведена в соответствии c методикой, изложенной выше. Выбранные показатели-представители, 
рекомендуемое значение которых характеризует приемлемое ЭЭС области, представлены в табл. 14 за базовый $\mathrm{t}_{0}$ и текущий $\mathrm{t}_{1}$ периоды.

Таблица 14

Показатели - представители, характеризующие ЭЭС

\begin{tabular}{|c|c|c|c|c|c|c|c|c|}
\hline Показатель & 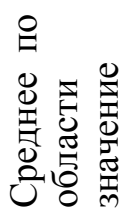 & 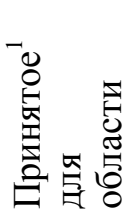 & Примечание & 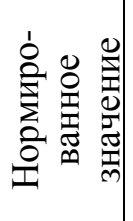 & 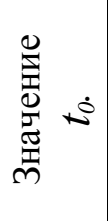 & 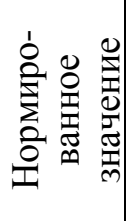 & 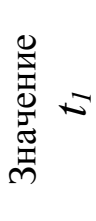 & 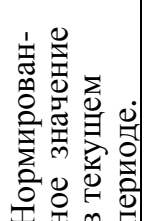 \\
\hline $\begin{array}{l}\text { 1. Темпы роста объема } \\
\text { эмиссии ЗВ, \%: } \\
\text { - выбросов в атмосферу }\end{array}$ & 101,7 & 101,2 & $\begin{array}{c}X_{\min }=83,47 \% \\
X_{\max }=107 \%\end{array}$ & 0,23 & 104,7 & 0,09 & 97,5 & 0,4 \\
\hline - сбросов в водные ресурсы; & 100,6 & 100,4 & $\begin{aligned} X_{\min } & =94,2 \% \\
X_{\max } & =106,5 \%\end{aligned}$ & 0,49 & 100,9 & 0,45 & $\begin{array}{c}103 \\
3\end{array}$ & 0,26 \\
\hline - размещения отходов & 101,2 & 101 & $\begin{aligned} X_{\min } & =70,3 \% \\
X_{\max } & =169,1 \%\end{aligned}$ & 0,44 & 105,0 & 0,64 & 97,5 & 0,72 \\
\hline $\begin{array}{l}\text { 2. Темп роста доли промыш- } \\
\text { ленной продукции отраслей- } \\
\text { загрязнителей в ВРП, \% }\end{array}$ & 100,1 & 96,3 & $\begin{array}{l}\mathrm{X}_{\min }=83,1 \% \\
\mathrm{X}_{\max }=116,3 \%\end{array}$ & 0,6 & 83,1 & 1 & 89,8 & 0,79 \\
\hline $\begin{array}{l}\text { 3. Темп роста основных фон- } \\
\text { дов природоохранного назна- } \\
\text { чения, рассчитанных на еди- } \\
\text { ницу ОПП, \% }\end{array}$ & 99,1 & 105,0 & $\begin{array}{c}X_{\min }=66,2 \% \\
X_{\max }=144,1 \%\end{array}$ & 0,50 & 78,0 & 0,14 & $\begin{array}{c}94,2 \\
6\end{array}$ & 0,36 \\
\hline $\begin{array}{l}\text { 4. Индекс роста эксплуата- } \\
\text { ционных затрат на охрану ОС } \\
\text { на руб. ОПП к затратам на } 1 \\
\text { руб. ТП, \% }\end{array}$ & 101,7 & 105 & $\begin{aligned} \mathrm{X}_{\min } & =83,3 \% \\
\mathrm{X}_{\max } & =109,4 \%\end{aligned}$ & 0,98 & 93,5 & 0,39 & $\begin{array}{c}70,6 \\
9\end{array}$ & 0 \\
\hline $\begin{array}{l}\text { 5.Темп прироста средних до- } \\
\text { ходов населения, рассчитан- } \\
\text { ных на единицу ОПП, \% }\end{array}$ & 97,4 & 115 & $\begin{array}{l}X_{\min }=84,15 \% \\
X_{\max }=147,8 \%\end{array}$ & 0,48 & 120,4 & 0,57 & $\begin{array}{c}111 \\
2\end{array}$ & 0,42 \\
\hline
\end{tabular}

Темп роста объема эмиссии ЗВ в текущем периоде, рассчитанный для условий Свердловской области, составил для выбросов в атмосферу 101,7 \% (при этом максимальное значение индекса, выбранное по тренду, равно $X_{\max }=106,6 \%$, минимальное $-X_{\min }=83,4 \%$ ), для сбросов $-100,6 \%$ ( $X_{\max }=106,4 \%, X_{\min }=94,2 \%$, соответственно), для размещения отходов $101,2 \%\left(X_{\max }=113,4 \%, X_{\min }=85,5 \%,[6]\right)$.

\footnotetext{
${ }^{1}$ Принятое для области значение рассчитывалось в соответствие с подходами, изложенными в главе 2.
} 
Аналогично определяются все остальные показатели с использованием данных представленных ранее в табл. 14. Нормирование показателей, рост значений которых ведет к ухудшению уровня ЭЭБ $\left(\bar{x}_{i}^{\uparrow}\right)$, выполняется с использованием формулы

$$
\bar{x}_{i}^{\uparrow}=1-\frac{x_{i}-x_{\min }}{x_{\max }-x_{\min }},
$$

Для показателей, снижение значений которых ведет к ухудшению уровню ЭЭБ, нормирование выполняется по формуле:

$$
\bar{x}_{i}^{\downarrow}=\frac{x_{i}-x_{\min }}{x_{\max }-x_{\min }} .
$$

Полученные нормированные значения вносятся в исходную (см. табл.14) и итоговую матрицы (табл. 16). Значения индексов оцениваются по шкале влияния на уровень ЭЭБ (табл.15).

Таблица 15

Шкала оценок влияния на ЭЭС

\begin{tabular}{|l|c|c|c|c|c|}
\hline \multicolumn{1}{|c|}{ Показатели-представители } & \multicolumn{5}{|c|}{ Шкала оценки } \\
\cline { 2 - 6 } & $\begin{array}{c}1 \\
60-85\end{array}$ & $\begin{array}{c}2 \\
8-110\end{array}$ & $\begin{array}{c}3 \\
110-135\end{array}$ & $\begin{array}{c}4 \\
135-160\end{array}$ & $\begin{array}{c}5 \\
160 \text { и более }\end{array}$ \\
\hline $\begin{array}{l}\text { Темп роста промышленной } \\
\text { продукции отраслей - загрязнителей } \\
\text { в доле от ОПП }\end{array}$ & $\begin{array}{c}\text { Очень } \\
\text { высокий }\end{array}$ & Высокий & $\underline{\text { Средний }}$ & Низкий & $\begin{array}{c}\text { Очень } \\
\text { низкий }\end{array}$ \\
\hline $\begin{array}{l}\text { Рост индекса ОПФ природоохран- } \\
\text { ного назначения, рассчитанных на } \\
\text { единицу ОПП }\end{array}$ & $\begin{array}{c}\text { Очень } \\
\text { низкий }\end{array}$ & $\underline{\text { Низкий }}$ & Средний & Высокий & $\begin{array}{c}\text { Очень } \\
\text { высокий }\end{array}$ \\
\hline $\begin{array}{l}\text { Темп роста загрязнения атмосферного } \\
\text { воздуха }\end{array}$ & $\begin{array}{c}\text { Очень } \\
\text { высокий }\end{array}$ & $\underline{\text { Высокий }}$ & Средний & Низкий & $\begin{array}{c}\text { Очень } \\
\text { низкий }\end{array}$ \\
\hline $\begin{array}{l}\text { Темп роста загрязнения водных } \\
\text { объектов }\end{array}$ & $\begin{array}{c}\text { Очень } \\
\text { высокий }\end{array}$ & $\underline{\text { Высокий }}$ & Средний & Низкий & $\begin{array}{c}\text { Очень } \\
\text { низкий }\end{array}$ \\
\hline $\begin{array}{l}\text { Темп роста загрязнения почвы } \\
\text { (земной поверхности) }\end{array}$ & $\begin{array}{c}\text { Очень } \\
\text { высокий }\end{array}$ & $\underline{\text { Высокий }}$ & Средний & Низкий & $\begin{array}{c}\text { Очень } \\
\text { низкий }\end{array}$ \\
\hline $\begin{array}{l}\text { Рост затрат на охрану ОС в расчете на } \\
\text { ед. ОПП и затрат на 1 руб ТП }\end{array}$ & $\begin{array}{c}\text { Очень } \\
\text { низкий }\end{array}$ & Низкий & Средний & Высокий & $\begin{array}{c}\text { Очень } \\
\text { высокий }\end{array}$ \\
\hline $\begin{array}{l}\text { Темп роста среднедушевого дохода } \\
\text { населения в расчете на ОПП }\end{array}$ & $\begin{array}{c}\text { Очень } \\
\text { низкий }\end{array}$ & $\underline{\text { Низкий }}$ & Средний & Высокий & $\begin{array}{c}\text { Очень } \\
\text { высокий }\end{array}$ \\
\hline
\end{tabular}


Область нормализованных значений параметров ЭЭБ

\begin{tabular}{|c|c|c|c|c|c|c|c|c|c|c|c|c|}
\hline Критерий оценки & 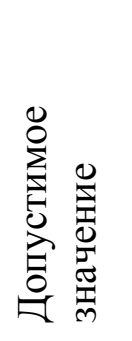 & 1 & 2 & 3 & 4 & 5 & 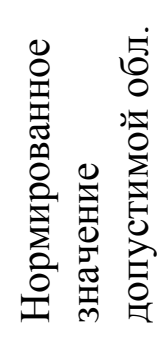 & 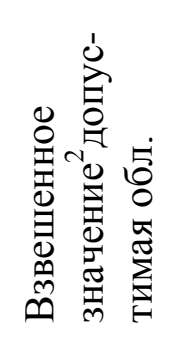 & 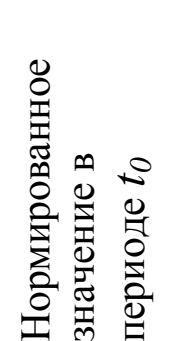 & 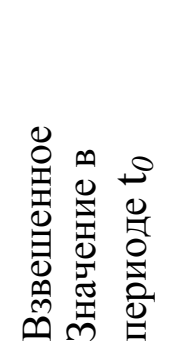 & 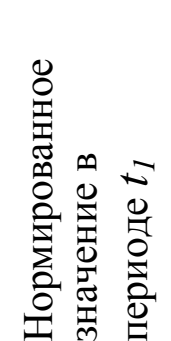 & 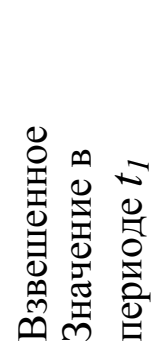 \\
\hline $\begin{array}{l}\text { Темп роста доли промышленной } \\
\text { продукции отраслей - } \\
\text { загрязнителей в ВРП }\end{array}$ & 96,3 & & & & & & 0,6 & 1,8 & 1 & 3 & 0,79 & 2,37 \\
\hline $\begin{array}{l}\text { Индекс ОПФ природоохранного } \\
\text { назначения в расчете на ОПП }\end{array}$ & 105,0 & & & & & & 0,5 & 1,0 & 0,14 & 0,28 & 0,36 & 0,72 \\
\hline $\begin{array}{l}\text { Темп роста загрязнения } \\
\text { атмосферного воздуха }\end{array}$ & 101,2 & & & & & & 0,23 & 0,46 & 0,09 & 0,2 & 0,4 & 0,8 \\
\hline $\begin{array}{l}\text { Темп роста загрязнения водных } \\
\text { объектов }\end{array}$ & 100,4 & & & & & & 0,49 & 0,98 & 0,45 & 0,9 & 0,26 & $\mathbf{0 , 5 2}$ \\
\hline $\begin{array}{l}\text { Темп роста загрязнения почвы } \\
\text { (земной поверхности) }\end{array}$ & 101,0 & & & & & & 0,44 & $\mathbf{0 , 8 8}$ & 0,64 & 1,28 & 0,72 & 1,44 \\
\hline $\begin{array}{l}\text { Индекс эксплуатационных } \\
\text { затрат на охрану ОС на единицу } \\
\text { ОПФ и затрат на } 1 \text { руб. ТП, \% }\end{array}$ & 105 & & & & & & 0,98 & 2,94 & 0,39 & 1,17 & 0 & $\mathbf{0}$ \\
\hline $\begin{array}{l}\text { Индекс средних доходов населе- } \\
\text { ния территории в расчете на ОПП }\end{array}$ & 115 & & & & & & 0,48 & 0,96 & 0,57 & 1,14 & 0,42 & $\mathbf{0 , 8 4}$ \\
\hline ИТОГО: & & & & & & & & 8,38 & & $\mathbf{7 , 8 9}$ & & 7,05 \\
\hline
\end{tabular}

\footnotetext{
${ }^{2}$ Значение взвешенного показателя более единицы свидетельствует о повышении состояния ЭЭБ и приближении к нормальному уровню
} 
Оценки влияния, дающие качественную характеристику количественному показателю, определяющему текущее значение, градированы по пятибалльной шкале. Наилучшему значению параметра присвоен балл, соответствующий 5.

Нормированные значения показателей взвешивались на соответствующий балл и суммировались для получения сводной оценки ЭЭБ. Суммарное значение сводной оценки $(S)$ приемлемого (допустимого) состояния для Свердловской области получено на низком уровне - 8,38, а сводная оценка текущуей ситуации еще ниже, что не свидетельствует о повышении уровня ЭЭБ области.

Сводная оценка текущего уровня ЭЭБ для Свердловской области по расчетам меньше на 1,1 \%. Однако, отклонения текущего уровня ЭЭБ от допустимого по основным экологическим параметрам незначительны, поэтому в дальнейшем важно поставить на контроль их динамику.

Мониторинг состояния выполняется с целью недопущения перехода в критическое состояние, т.к. снижение сводной оценки $S$ ЭЭБ уменьшает ассимиляционный потенциал территории и возможность противостоять техногенной нагрузке, что ведет к неустойчивости эколого-экономической системы в целом.

\section{Вопросы и задания для самопроверки}

1. Условия формирования системы «показателей - представителей».

2. Характеристика индикаторов, определяемых как показатели-представители.

3. Условия формирования матрицы «Шкала оценок влияния на ЭЭС».

4. Понятие «области нормализованных значений параметров ЭЭБ.

5. Условия формирования области нормализованных значений параметров ЭЭБ.

6. Матрица нормализованных значений.

7. Характеристика частных и сводной оценок допустимого состояния ЭЭБ.

8. Характеристика частных и сводной оценок текущего состояния ЭЭБ.

\section{Рекомендуемая литература}

1. Белик И. С. Влияние эколого-экономической безопасности на выбор стратегических инвестиционных решений / И. С. Белик . Екатеринбург : УГТУ-УПИ, 2008.

2. Белик И. С.Экологические приоритеты инвестиционной активности территории / И.С. Белик, Н.В. Стародубец. Екатеринбург: УГТУ-УПИ, 2009.

3. Проблемы устойчивого развития социально-экономических ситсем. / А. И. Татаркин, В. В. Криворотов, И. С. Белик [и др.]; под ред. А. И. Татаркина. Изд-во: Экономика, 2012. 


\section{3. Роль эколого-экономической безопасности в реализации модели устойчивого развития региона}

Промышленно развитые регионы страны, являясь основными пользователями природных ресурсов, чаще всего проявляют себя как территории, основным видом деятельности которых служит добыча, поставка и частичная переработка полезных ископаемых. В экономической литературе их принято называть территориями ресурсного типа. Для территорий ресурсного типа обязательными требованиями, закладываемыми в основу принципов, формирующих инвестищионную политику, и промышленную политику должны стать положения, связанные с качеством воспроизводства ресурсов, реализуемые через принципы «последовательного улучшения» и «предотвращения воздействия на ОС».

Основанием служат причины, связанные с ужесточением требований к проектированию и оценке разрабатываемых предпроектных и проектных материалов (федеральный закон «Об экологической экспертизе» от 23 ноября 1995 г. № 174-Ф3), обязывающие любые проектные решения рассматривать в контексте фактически сущуествующей экологической ситуащчии в районе намечаемой деятельности.

В этом аспекте можно говорить об актуальности диагностики ЭЭБ, особенно для ресурсных территорий. Результаты диагностики ЭЭБ дают возможность:

- классифицировать объекты воздействия хозяйственной деятельности на ОС по степени их эколого-экономической опасности;

- систематизировать их на уровне структурных субъектов федерации;

- вырабатывать эколого-экономические приоритеты развития.

Отмеченное имеет практическое значение для учета природно-ресурсной спецификки территории при ее зонировании, т. е. выделении зон (рис. 8) с контрольным (средним), нормальным и пороговым (высоким) уровнем экологоэкономической опасности и помогает решить проблему применения 
дифференцированного подхода к объектам различного масштаба воздействия на природную среду. Однако эти задачи выполнимы при условии передачи экологической информачии в систему принятия решений.

В плане использования результатов диагностики в системе прогнозирования и программирования социального, эколого-экономического развития территории важно закрепление их в качестве нормативного положения для учета эколого-экономических ограничений. Положение об учете эколого-экономических ограничений в процессе разработки социальноэкономических программ призвано отражать в документах стратегического уровня показатели, характеризующие изменение качества OC при экономическом росте региона (объем ОПП, среднедушевой доход населения), контролировать изменение целевых параметров при реализащии программ, выявлять экологические нарушения, связанные с выходом за установленные ограничения (пределы).

Проблема актуальна для ресурсных территорий и, относимых к зонам с высоким уровнем эколого-экономической опасности (пороговый и контрольный). Для последних допустимо введение прямого регулирования процессами экономического развития, предусматривающего разработку экономических санкций или административных мер (см. рис. 8), а в случае технической или технологической нерешенности проблем применение мер, связанных с изменением цุелевых установок планов и программ развития.

Следует отметить, что полномочия территориальных органов на уровне региона и муниципального образования (табл. 17) позволяют изменять целевые установки развития как со стороны распоряжения природными, трудовыми, производственными, финансовыми и др. ресурсами, так и эффективного управления ими с использованием системы экономического стимулирования.

Организация диагностики и контроля за выполнением экологических требований со стороны региональных органов, а также органов исполнительной 


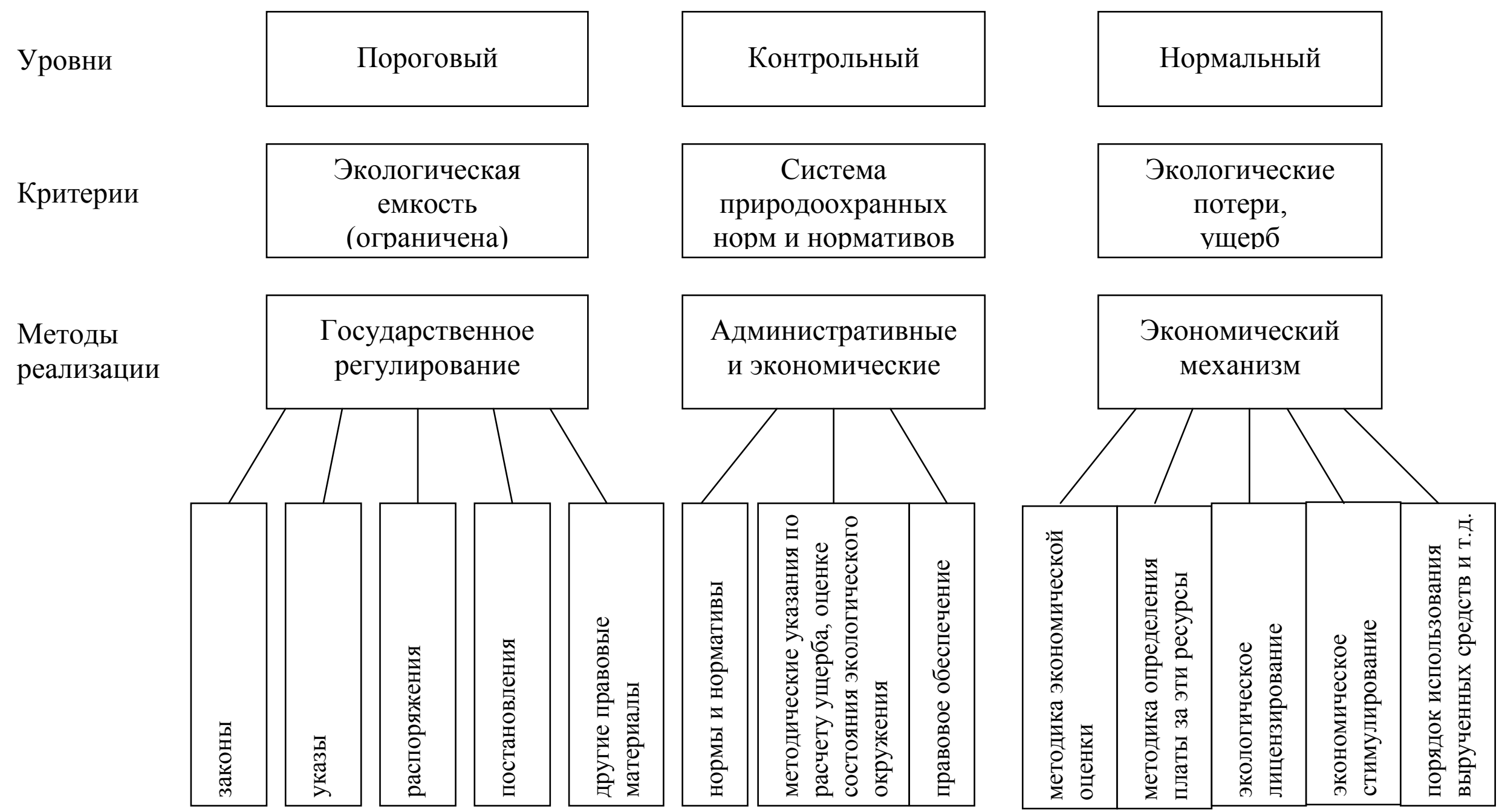

Рис.8. Административные и экономические методы регулирования развития территориальных образований с разными уровнями экологических ограничений [20] 
Уровень полномочий и ответственности

\begin{tabular}{|l|c|c|}
\hline \multirow{2}{*}{ Основные элементы механизма } & \multicolumn{2}{|c|}{ Уровень полномочий } \\
\cline { 2 - 3 } & $\begin{array}{c}\text { структурные } \\
\text { формирования } \\
\text { субъекта Федерации }\end{array}$ & $\begin{array}{c}\text { муниципальные } \\
\text { образования }\end{array}$ \\
\hline $\begin{array}{l}\text { Планирование использования природных } \\
\text { ресурсов }\end{array}$ & + & - \\
\hline Финансирование и кредитование & + & + \\
\hline Ценообразование & + & - \\
\hline Налоговая система & + & + \\
\hline Внебюджетные фонды & + & + \\
\hline Страховые фонды & + & + \\
\hline $\begin{array}{l}\text { Общая оценка и диагностика природных, } \\
\text { трудовых, производственных и др. } \\
\text { ресурсов }\end{array}$ & + & + \\
\hline Прогнозирование и программирование & + & + \\
\hline Диагностика ЭЭБ & + & + \\
\hline Контроль и учет использования ресурсов & + & + \\
\hline
\end{tabular}

власти и местного самоуправления, как правило, осуществляется в рамках использования административно - правовых методов, применяемых в рамках государственного регулирования природоохранной деятельности (рис. 9) и могут рассматриваться как экономические инструменты реализации стратегических решений.

Административно-правовые меры в первую очередь связаны с разработкой и созданием процедур реализации природоохранных законов и введением мер экономического характера, которые усиливают роль государства в плане правового и административного воздействия на объекты хозяйственной деятельности и природно-технического характера. В настоящее время основой системы экономического стимулирования, направленной на сдерживание техногенного воздействия хозяйствующих субъектов, являются платежи за загрязнение, инвестиции в основной капитал природоохранного назначения, лимиты на природопользование, экологические фондь,, экологическое 

природопользование, охрану ОС.

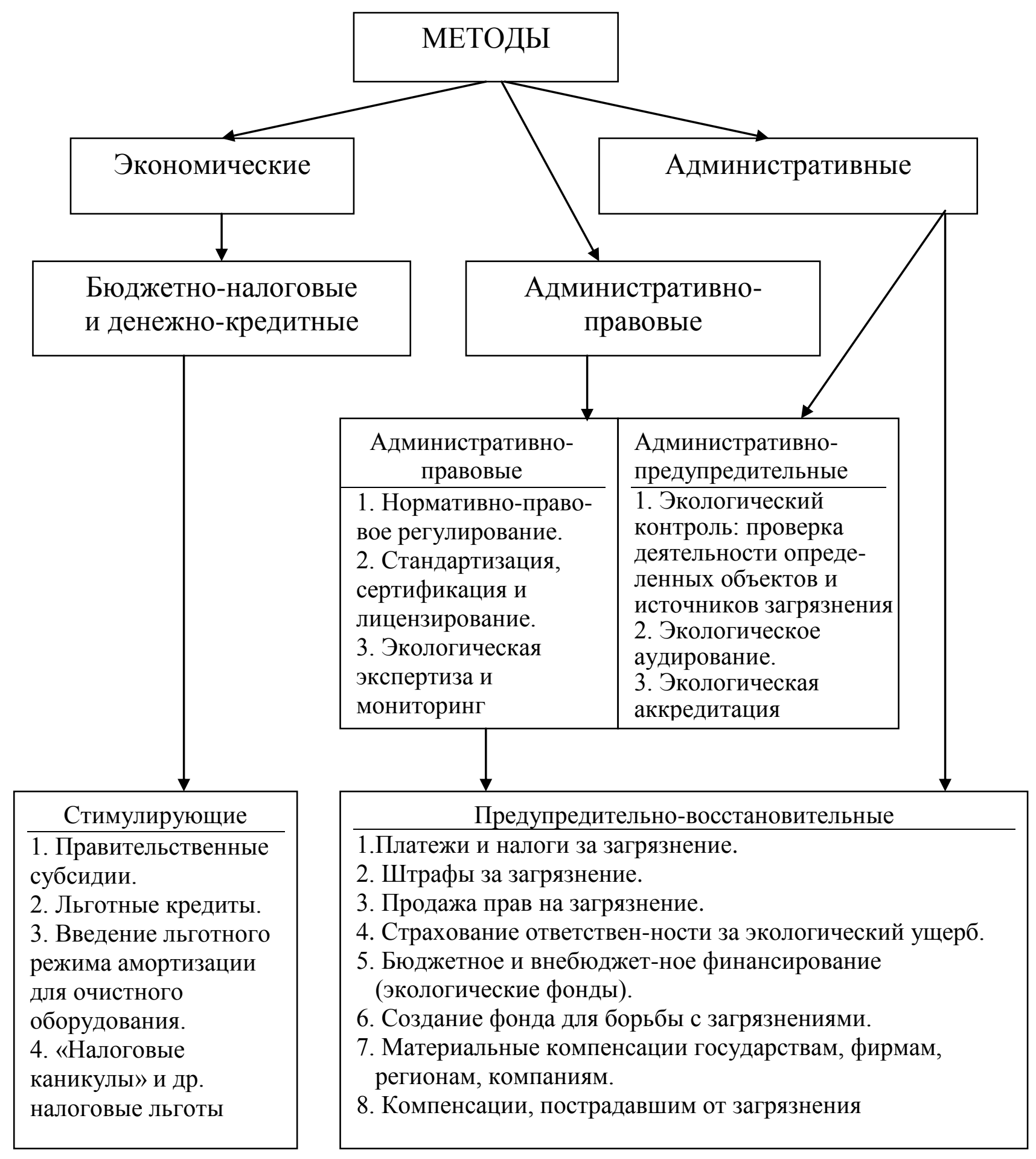

Рис. 9. Методы регулирования качества природной среды на территориях, относимых к пороговому и контролируемому уровням [20] 
Среди мер, являющихся важнейшим экономическим регулятором до конца 90-х гг., признавались платежи за природопользование, включающие плату за загрязнение ОС. Но в настоящее время удельный вес начисленных платежей (табл. 18) за загрязнение ОС в стоимости валовой продукции промышленности как по стране, так и отдельных территорий невысокий (Свердловская область менее $0,5 \%,[14]$ ), очевидно что инструмент не выполняет возложенной на него функции.

Таблица 18

Платежи за загрязнение ОС, Свердловская область, млн. руб.

\begin{tabular}{|l|c|c|c|c|c|c|c|c|}
\hline \multirow{2}{*}{\multicolumn{1}{|c|}{ Показатель }} & \multicolumn{2}{|c|}{ Вода } & \multicolumn{2}{c|}{ Воздух* } & \multicolumn{2}{c|}{ Отходы } & \multicolumn{2}{c|}{$\begin{array}{l}\text { По всем } \\
\text { средам }\end{array}$} \\
\cline { 2 - 10 } & $t_{0}$ & $t_{1}$ & $t_{0}$ & $t_{1}$ & $t_{0}$ & $t_{1}$ & $t_{0}$ & $t_{1}$ \\
\hline $\begin{array}{l}\text { Плата за загрязнение } \\
\text { начисленная, всего, }\end{array}$ & 142,3 & 82,67 & 221,4 & 208,37 & 310,0 & 377,21 & 673,7 & 668,23 \\
\hline $\begin{array}{l}\text { в том числе } \\
\text { сбросы в пределах ПДС } \\
\text {-выбросы в } \\
\text { пределах ПдВ }\end{array}$ & 20,96 & 19,19 & & & & & & \\
\hline $\begin{array}{l}\text { - в пределах } \\
\text { установленных } \\
\text { лимитов }\end{array}$ & - & - & 72,3 & 51,49 & & & 93,3 & 396,12 \\
\hline $\begin{array}{l}\text { - за сверхлимитные } \\
\text { выбросы (сбросы) }\end{array}$ & 81,16 & 26,97 & 70,71 & 89,29 & 57,46 & 51,78 & 209,3 & 168,05 \\
\hline
\end{tabular}

*Плата за загрязнение атмосферы только от стационарных источников ввиду отсутствия данных о размерах платежей за загрязнение атмосферы от передвижных источников в целом по области

Важнейшим фактором роста территорий ресурсного типа, характеризующихся массовым использованием воспроизводимых и невоспроизводимых природных ресурсов, является условие обеспечения воспроизводства природно-ресурсной подсистемы. Данное обстоятельство является причиной того, что механизм экономического стимулирования экологически безопасного экономического роста территории должен содержать инструменты экономического регулирования как взыскательного, так и стимулирующего характера.

К традиционным стимулирующим методам, применяемым на уровне территории, предлагается дополнительно ввести следующие:

- дифференциацию цен на земельные участки и платы за жилье в зависимости от экологических факторов; 
- специальные налоговые режимы для регионов особого экологоэкономического статуса;

- льготное кредитование проектов, применяющих низкоуглеродные технологии, налоговые льготы хозяйствующим субъектам, участвующим в системе государственного партнерства по направлениям энергосбережение, лесопользование;

- систему льготного режима амортизащии для очистного оборудования.

- Методы взыскательного характера сделать более жесткими в части платежей за загрязнение путем ввода:

- обоснованности ставок платы за загрязнение ущербами, наносимыми ОС и здоровью населения конкретными видами загрязнения;

- режимом страхования ответственности за экологический ущерб.

Отмеченные меры позволят учесть природовосстановительную функцию в стоимостной оценке эффективности функционирования экономики территории.

Управление эколого-экономическим развитием, предполагает содержание в своей структуре экологически обеспеченный вариант экономического роста, который призван переориентировать общество на контролируемое ресурсопотребление и создать предпосылки ограничения технологического направления развития.

Пример учета в сценариях развития результатов диагностики ЭЭБ

По разработанным Правительством Свердловской области сценариям социально-экономического развития, выполнены расчеты прогнозных значений уровня ЭЭБ на $t_{1+i}$ период в разрезе сценариев - инерциинного (табл. 19, табл. 20), инновацчионного (табл. 21, табл. 22), инерц̧ионного с учетом снижения объемов производства (табл. 23, табл. 24) с использованием показателей диагностики. 
Таблица 19

Прогнозные значения уровня ЭЭБ на $t_{1+i}$ период по инеричинному сценарию:

\begin{tabular}{|c|c|c|c|c|c|c|}
\hline \multirow[t]{2}{*}{ Показатель } & \multicolumn{2}{|c|}{$\begin{array}{c}\text { Наибольшее и } \\
\text { наименьшее значение } \\
\text { показателя }\end{array}$} & \multirow{2}{*}{ 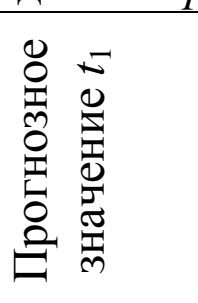 } & \multirow{2}{*}{ 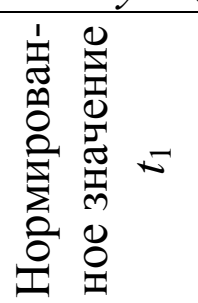 } & \multirow{2}{*}{ 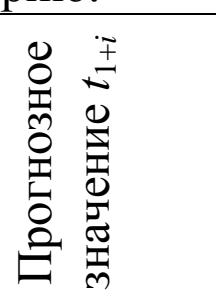 } & \multirow{2}{*}{ 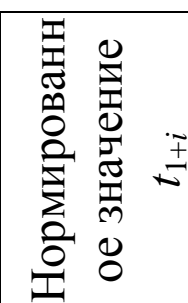 } \\
\hline & $\max$ & $\min$ & & & & \\
\hline $\begin{array}{l}\text { 1. Темпы роста объема эмиссии 3В, \% } \\
\text { - выбросов в атмосферу }\end{array}$ & 107,00 & 83,50 & 99,03 & 0,34 & 91,16 & 0,67 \\
\hline - сбросов в водные ресурсы; & 106,50 & 94,20 & 99,87 & 0,54 & 102,41 & 0,33 \\
\hline - размещения отходов & 156,10 & 85,50 & 115,6 & 0,57 & 115,60 & 0,57 \\
\hline $\begin{array}{l}\text { 2. Темп роста доли промышленной } \\
\text { продукции отраслей-загрязнителей, \% }\end{array}$ & 116,47 & 70,78 & 84,86 & 0,69 & 84,86 & 0,79 \\
\hline $\begin{array}{l}\text { 3. Темп роста основных фондов } \\
\text { природоохранного назначения, } \\
\text { рассчитанных на единицу ОПП, \% }\end{array}$ & 143,30 & 61,10 & 98,40 & 0,45 & 98,01 & 0,45 \\
\hline $\begin{array}{l}\text { 4. Индекс роста эксплуатационных } \\
\text { затрат на охрану ОС на руб. ОПП к } \\
\text { затратам на } 1 \text { руб. ТП, \% }\end{array}$ & 105,10 & 69,16 & 78,01 & 0,25 & 75,01 & 0,16 \\
\hline $\begin{array}{l}\text { 5.Темп прироста средних доходов } \\
\text { населения, рассчитанных на единицу } \\
\text { ОПП, \% }\end{array}$ & 147,8 & 85,80 & 116,90 & 0,5 & 116,90 & 0,5 \\
\hline
\end{tabular}


Область нормализованных значений параметров ЭЭБ (по инериионному сценарию)

\begin{tabular}{|c|c|c|c|c|c|c|c|c|c|}
\hline Критерий оценки & 1 & 2 & 3 & 4 & 5 & 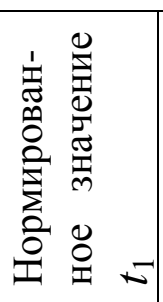 & 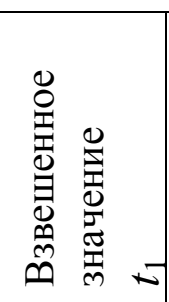 & 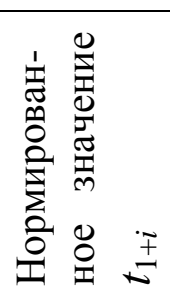 & 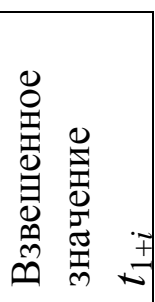 \\
\hline $\begin{array}{l}\text { 1. Темпы роста объема } \\
\text { эмиссии 3В, \%: } \\
\text { - выбросов в атмосферу; }\end{array}$ & & & & & & 0,34 & 0,68 & 0,67 & 1,35 \\
\hline $\begin{array}{l}\text { - сбросов в водные } \\
\text { ресурсы; }\end{array}$ & & & & & & 0,54 & 1,08 & 0,33 & $\mathbf{0 , 6 7}$ \\
\hline - размещения отходов & & & & & & 0,57 & 1,14 & 0,57 & 1,15 \\
\hline $\begin{array}{l}\text { 2. Темп роста доли } \\
\text { промышленной продукции } \\
\text { отраслей-загрязнителей, \% }\end{array}$ & & & & & & 0,69 & 2,08 & 0,79 & 2,37 \\
\hline $\begin{array}{l}\text { 3. Темп роста основных } \\
\text { фондов природоохранного } \\
\text { назначения, рассчитанных } \\
\text { на единицу ОПП, \% }\end{array}$ & & & & & & 0,45 & 0,91 & 0,45 & $\mathbf{0 , 9 0}$ \\
\hline $\begin{array}{l}\text { 4. Индекс роста } \\
\text { эксплуатационных затрат } \\
\text { на охрану ОС на руб. ОПП } \\
\text { к затратам на } 1 \text { руб. ТП, \% }\end{array}$ & & & & & & 0,25 & 0,74 & 0,16 & 0,49 \\
\hline $\begin{array}{l}\text { 5.Темп прироста средних } \\
\text { доходов населения, } \\
\text { рассчитанных на единицу } \\
\text { ОПП, \% }\end{array}$ & & & & & & 0,5 & 1 & 0,5 & 1 \\
\hline ИТОГО: & & & & & & & 7,63 & & 7,92 \\
\hline
\end{tabular}

В результате представленных расчетов ЭЭБ можно сделать выводы о том, что социально-экономическое развитие области по инерционному сценарию приведет к незначительному повышению уровня ЭЭБ. Следуя инерционному сценарию, значение прогнозного показателя ЭЭБ в $t_{1+i}$ периоде увеличится на $4 \%$ по сравнению с прогнозным уровнем ЭЭБ в периоде $t_{1}$. 
Таблица 21

Прогнозные значения уровня ЭЭБ на период $\mathrm{t}_{1+\mathrm{i}}$ по инновационному сценарию:

\begin{tabular}{|c|c|c|c|c|c|c|}
\hline \multirow[t]{2}{*}{ Показатель } & \multicolumn{2}{|c|}{$\begin{array}{c}\text { Наибольшее и } \\
\text { наименьшее } \\
\text { значение показателя }\end{array}$} & \multirow{2}{*}{ 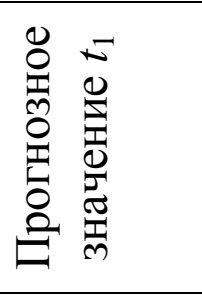 } & \multirow{2}{*}{ 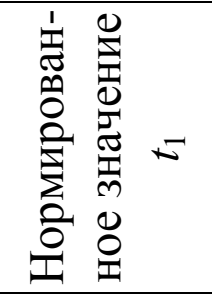 } & \multirow{2}{*}{ 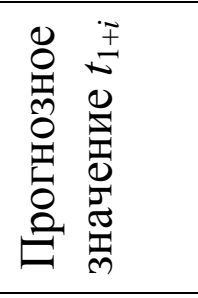 } & \multirow{2}{*}{ 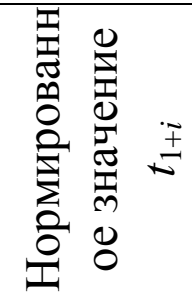 } \\
\hline & $\max$ & $\min$ & & & & \\
\hline $\begin{array}{l}\text { 1. Темпы роста объема эмиссии 3В, } \\
\text { - выбросов в атмосферу }\end{array}$ & 107,00 & 83,50 & 98,91 & 0,44 & 97,08 & 0,42 \\
\hline - сбросов в водные ресурсы; & 106,50 & 89,40 & 99,85 & 0,59 & 89,43 & 1,00 \\
\hline - размещения отходов & 156,10 & 77,60 & 101,53 & 0,7 & 77,56 & 1,00 \\
\hline $\begin{array}{l}\text { 2. Темп роста доли промышленной } \\
\text { продукции отраслей-загрязнителей, \% }\end{array}$ & 116,47 & 70,15 & 88,68 & 0,6 & 82,54 & 0,85 \\
\hline $\begin{array}{l}\text { 3. Темп роста основных фондов } \\
\text { природоохранного назначения, } \\
\text { рассчитанных на единицу ОПП, \% }\end{array}$ & 112,10 & 66,20 & 96,74 & 0,67 & 96,07 & 0,65 \\
\hline $\begin{array}{l}\text { 4. Индекс роста эксплуатационных } \\
\text { затрат на охрану ОС на руб. ОПП к } \\
\text { затратам на } 1 \text { руб. ТП, \% }\end{array}$ & 105,10 & 69,16 & 77,43 & 0,23 & 74,45 & 0,15 \\
\hline $\begin{array}{l}\text { 5.Темп прироста средних доходов } \\
\text { населения, рассчитанных на единицу } \\
\text { ОПП, \% }\end{array}$ & 147,80 & 85,80 & 103,06 & 0,28 & 118,83 & 0,53 \\
\hline
\end{tabular}


Таблица 22

Область нормализованных значений параметров ЭЭБ (по инновационному сценарию)

\begin{tabular}{|l|l|l|l|l|l|l|l|l|}
\hline \multicolumn{1}{|c|}{ Критерий оценки } & 1 & 2 \\
\end{tabular}

Социально-экономическое развитие области по инновационному сценарию по полученным прогнозным расчетам значительно повышает уровень ЭЭБ Свердловской области. Об этом свидетельствует высокое значение прогнозного уровня ЭЭБ, определенного для условий $t_{1}$, и приращение показателя на 29 \% к периоду $t_{1+i}$.

Социально-экономическое развитие области по инерционному сценарию с учетом сокращения объемов производства по прогнозным расчетам приведет к 
Таблица 23

Прогнозные значения уровня ЭЭБ на $t_{1+i}$ по инериионному сценарию с учетом сокращения объемов производства

\begin{tabular}{|c|c|c|c|c|c|c|c|c|}
\hline \multirow[b]{2}{*}{ Показатель } & \multicolumn{2}{|c|}{ Примечание } & \multicolumn{2}{|c|}{$\begin{array}{c}\text { Прогнозное } \\
\text { значение }\end{array}$} & \multicolumn{2}{|c|}{$\begin{array}{l}\text { Нормированное } \\
\text { прогнозное }\end{array}$} & \multicolumn{2}{|c|}{$\begin{array}{l}\text { Взвешенное } \\
\text { значение }\end{array}$} \\
\hline & $\max$ & $\min$ & $t_{1}$ & $t_{1+i}$ & $t_{1}$ & $t_{1+i}$ & $t_{1}$ & $t_{1+i}$ \\
\hline $\begin{array}{l}\text { Объемы выбросов от стационарных } \\
\text { источников, \% }\end{array}$ & 107,00 & 83,47 & 96,07 & 96,07 & 0,46 & 1,00 & 0,93 & 2,00 \\
\hline $\begin{array}{l}\text { Объемы сбросов в водные ресурсы, } \\
\%\end{array}$ & 106,47 & 94,19 & 99,41 & 99,41 & 0,57 & 0,57 & 1,15 & 1,15 \\
\hline $\begin{array}{l}\text { Объемы размещения твердых } \\
\text { отходов, \% }\end{array}$ & 156,12 & 58,38 & 99,61 & 99,61 & 0,58 & 0,58 & 1,16 & 1,16 \\
\hline $\begin{array}{l}\text { Темп роста доли } \\
\text { промышленной продукции } \\
\text { отраслей загрязнителей, \% }\end{array}$ & 116,47 & 80,56 & 97,33 & 97,33 & 0,53 & 0,53 & 1,60 & 1,60 \\
\hline $\begin{array}{l}\text { Темп роста основных фондов } \\
\text { природоохранного назначения, } \\
\text { рассчитанных на единицу ОПП, \% }\end{array}$ & 143,35 & 61,06 & 87,59 & 87,40 & 0,32 & 0,32 & 0,64 & 0,64 \\
\hline $\begin{array}{l}\text { Индекс роста эксплуатационных } \\
\text { затрат на охрану ОС на руб. ОПП к } \\
\text { затратам на } 1 \text { руб. ТП, \% }\end{array}$ & 111,81 & 65,30 & 68,13 & 65,30 & 0,06 & 0,00 & 0,18 & 0,00 \\
\hline $\begin{array}{l}\text { Темп прироста средних доходов } \\
\text { населения, рассчитанных на } \\
\text { единицу ОПП, \% }\end{array}$ & 130,68 & 91,42 & 107,40 & 107,40 & 0,41 & 0,41 & 0,81 & 0,81 \\
\hline ИТОГО: & & & & & & & 6,48 & 7,36 \\
\hline
\end{tabular}


Таблица 24

Область нормализованных значений параметров ЭЭБ по инерционному сиенарию с учетом сокращения объемов производства

\begin{tabular}{|c|c|c|c|c|c|c|c|c|c|}
\hline Критерий оценки & 1 & 2 & 3 & 4 & 5 & 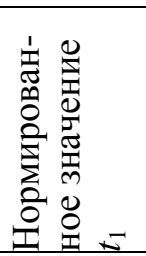 & 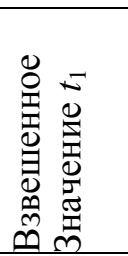 & 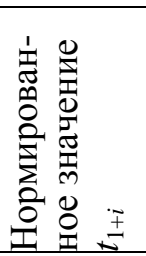 & 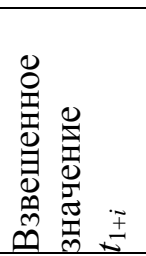 \\
\hline $\begin{array}{l}\text { 1. Темпы роста объема } \\
\text { эмиссии ЗВ, \%: } \\
\text { - выбросов в атмосферу; }\end{array}$ & & & & & & 0,46 & $\mathbf{0 , 9 3}$ & 1,00 & 2,00 \\
\hline $\begin{array}{l}\text { - сбросов в водные } \\
\text { ресурсы; }\end{array}$ & & & & & & 0,57 & 1,15 & 0,57 & 1,15 \\
\hline - размещения отходов & & & & & & 0,58 & 1,16 & 0,58 & 1,16 \\
\hline $\begin{array}{l}\text { 2. Темп роста доли } \\
\text { промышленной продукции } \\
\text { отраслей-загрязнителей, \% }\end{array}$ & & & & & & 0,53 & 1,60 & 0,53 & 1,60 \\
\hline $\begin{array}{l}\text { 3. Темп роста основных } \\
\text { фондов природоохранного } \\
\text { назначения, рассчитанных } \\
\text { на единицу ОПП, \% }\end{array}$ & & & & & & 0,32 & 0,64 & 0,32 & 0,64 \\
\hline $\begin{array}{l}\text { 4. Индекс роста } \\
\text { эксплуатационных затрат } \\
\text { на охрану ОС на руб. ОПП } \\
\text { к затратам на } 1 \text { руб. ТП, \% }\end{array}$ & & & & & & 0,06 & 0,18 & 0,00 & 0,00 \\
\hline $\begin{array}{l}\text { 5.Темп прироста средних } \\
\text { доходов населения, } \\
\text { рассчитанных на единицу } \\
\text { ОПП, \% }\end{array}$ & & & & & & 0,41 & $\mathbf{0 , 8 1}$ & 0,41 & $\mathbf{0 , 8 1}$ \\
\hline ИТОГО: & & & & & & & 6,48 & & 7,36 \\
\hline
\end{tabular}

снижению уровня ЭЭБ в $t_{1+i}$ периоде. Рост сводной оценки ЭЭБ составит $13 \%$ от прогнозного уровня $t_{1}$.

Учитывая возможные варианты экономического развития по пессимистическому сценарию (в рассматриваемом примере ему соответствует инерционный сценарий с учетом сокращения объемов производства), определены частная и сводная оценки состояния ЭЭБ и для этого варианта (табл. 23, 24).

В настоящее время на практике выбор типа инвестиционной политики зависит от приоритетов, установленных в сценариях социально-экономического развития, которые не учитывают ЭЭС региона. Поэтому предварительная 
оценка объема инвестиций, требуемых для реализации того или иного сценария, не содержит вариантов экологически обеспеченного развития.

\section{Вопросы и задания для самопроверки}

1. Дайте характеристику «пороговому», «нормальному», «критическому» уровню ЭЭС территории.

2. Опишите экономические и административные меры, применяемые для территорий, характеризуемых состоянием «пороговый», «критический» уровень.

3. Опишите порядок формирования области нормализованных значений параметров ЭЭБ на $t_{1+i}$ период по инерционному сценарию.

4. Опишите порядок формирования области нормализованных значений параметров ЭЭБ на период $t_{1+i}$ по инновационному сценарию.

6. Опишите порядок формирования области нормализованных значений параметров ЭЭБ на период $t_{1+i}$ по инерционному сценарию с учетом сокращения объемов производства.

\section{Рекомендуемая литература}

1. Белик И. С. Влияние эколого-экономической безопасности на выбор стратегических инвестиционных решений / И. С. Белик. Екатеринбург : УГТУ-УПИ, 2008. 117 с.

2. Белик И. С. Экологические приоритеты инвестиционной активности территории / И. С. Белик, Н. В. Стародубец. Екатеринбург: УГТУ-УПИ, 2009. 173 с.

3. Проблемы устойчивого развития социально-экономических ситсем / А. И. Татаркин, В. В. Криворотов, И. С. Белик [и др.]; под ред. А. И. Татаркина. Изд-во: Экономика, 2012. 555 с.

\section{ГЛАВА З. ИНСТРУМЕНТАРИЙ УЧЕТА В СТРАТЕГИЯХ РАЗВИТИЯ РЕГИОНА ОЦЕНКИ ЭКОЛОГО- ЭКОНОМИЧЕСКОЙ БЕЗОПАСНОСТИ}

\section{1. Обоснование выбора инвестиционной политики на основе оценки уровня эколого-экономической безопасности региона}

В настоящее время территории ресурсного типа сталкиваются с таким явлением как дисбаланс в уровне развития экономической, социальной, экологической сфер. Понимание государственными органами управления дисбаланса в уровне развития в той или иной степени должно находить отражение в инвестиционной политике, обеспечивающей условия простого и расширенного воспроизводства.

На этапе принятия инвестиционной политики активная заинтересованность всех участников (департамент экономики; орган, планирующий размещение производительных сил; департамент инвестиций; 
департамент промышленности и др.) в экологических аспектах дает следующие результаты:

- получение достоверной информации для подготовки и принятия экологически обоснованных решений, оценки существующей экологической ситуации и влияния фактических результатов любой реализованной деятельности на природную среду;

- снижение итрафов и затрат по платежам за природопользование и загрязнение OC;

- выявление дополнительных средств за счет экономии сырья, материалов, электроэнергии, топлива, природных ресурсов и т. д. в схеме реальных источников финансирования программ (рис. 10, [7]).

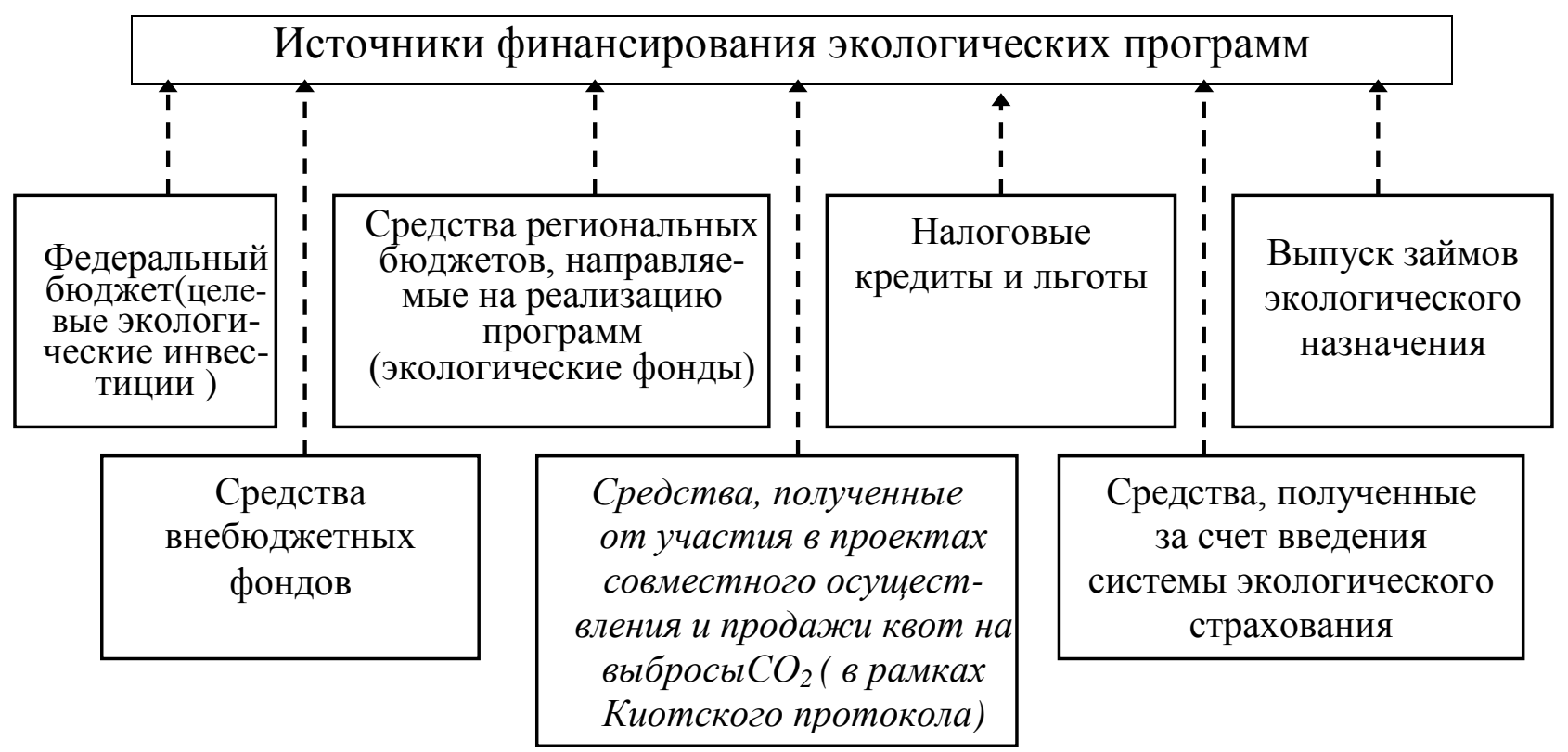

Рис. 10. Источники финансирования экологических программ

Реализация принциов «последовательного улучшения» и «предотвращения воздействия на ОС» осуществляется путем мотиваџии природоохранной и сочуиально ориентированной деятельности субъектов инвестиционного рынка, правового закрепления стимулирующей экологической и социальной направленности действующего законодательства, развития экологического предпринимательства, системы софинансирования природоохранных проектов и т. д. 
Все перечисленное относится к методам государственного регулирования в сфере поддержания благоприятного инвестиционного климата. Однако условием, необходимым для его реализации на территориях ресурсного типа, является соответствие инвестищионного предложения ресурсопотребляющих производственных комплексов качеству природной среды и среды жизнедеятельности человека

Создание благоприятного климата в ресурсных кластерах предполагает разработку инвестиционной политики, которая формируется с учетом ЭЭС региона и ориентируется:

- на дифференцичацию по группам состояния ресурсных территорий;

- поддержку инвестиционных объектов, обладающих помимо коммерческой и экологической эффективностью;

- взаимодействие систем принятия стратегических решений хозяйственного развития и регулирования инвестиционного климата региона.

С учетом изложенного, система регулирования условий поддержания благоприятного инвестиционного климата регионов ресурсного типа, должна включать приоритеты эколого-экономического развития. В этой связи схема взаимодействия (рис. 11) механизма принятия стратегических управленческих решений и регулирования инвестиционного климата региона должна содержать общий этап - формирования соответствующеего типа инвестищионной политики. Последнее реализуется посредством введения процедуры разработки «когнитивных» карт, включающей матрицу распределения инвестищий и карту оиченки коэффициентов значимости как основы выбора типа инвестиционной политики, соответствующей эколого-экономическому развитию региона.

Согласно схеме (рис. 11, [6]) взаимодействие механизма реализации стратегических решений развития и системы регулирования условий поддержания инвестиционного климата региона осуществляется на этапе формирования типа инвестиционной политики (блок 1, см. рис. 11). 


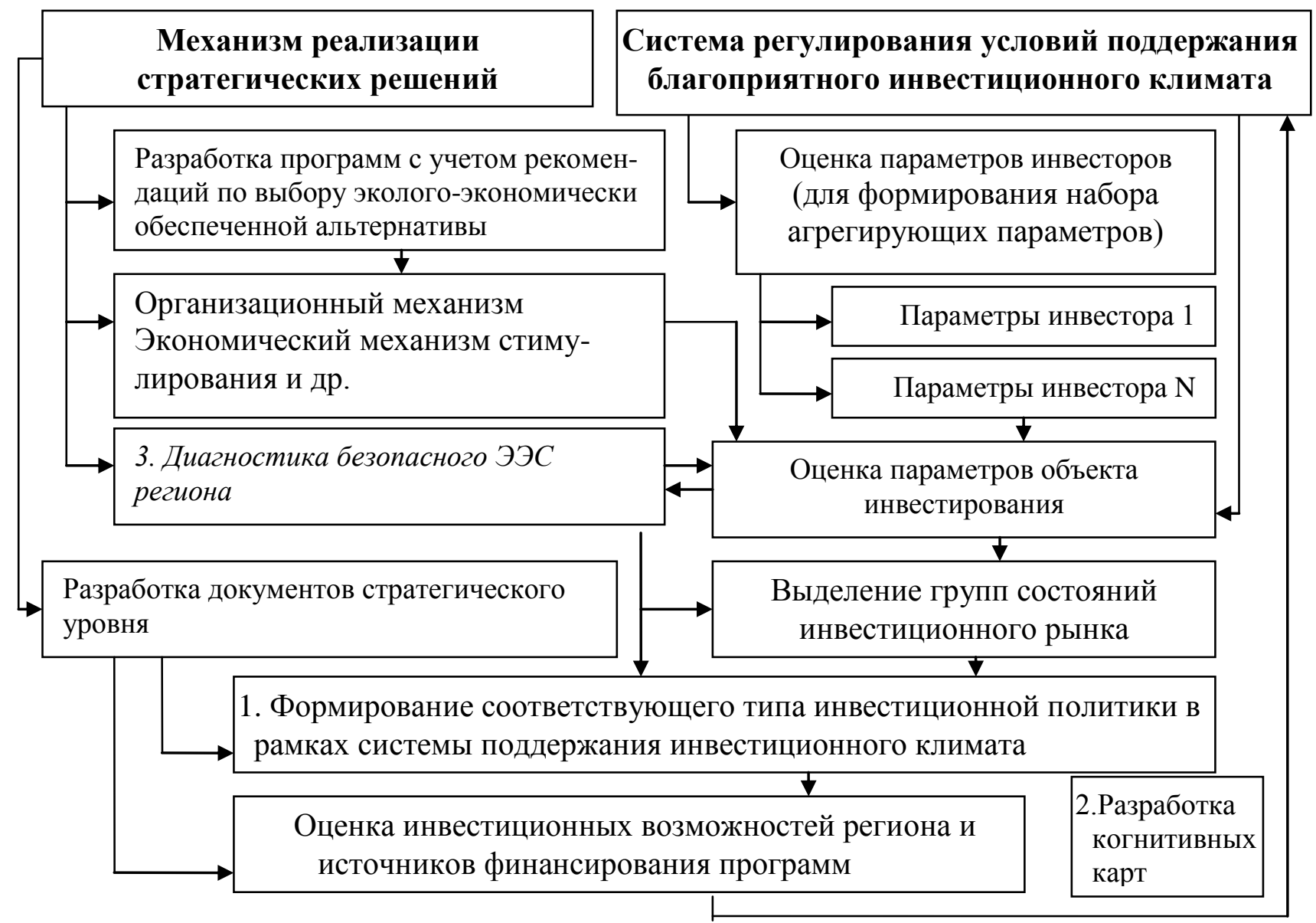

Рис. 11. Схема взаимодействия систем принятия стратегических управленческих решений и регулирования инвестиционного климата региона

Результаты диагностики ЭЭБ используются на этапе выбора конкретного muna инвестиционной политики, соответствующей сценарию социальноэкономического развития региона. С этой целью вводится процедура формирования когнитивных карт (табл. 25), которая учитывает комплексную оценку диагностики ЭЭБ. Процедура разработки когнитивных карт состоит из формирования матрищы распределения инвестищий (см. табл. 25) и карты оценки коэффициента значимости (табл. 26) и носит регулятивный характер.

Матрица распределения инвестиций (см. табл. 25) отражает потребность в капитале для соответствующего $n$-го сценария развития при проведении инвестиционной политики $i$-го типа, которая рассчитывается с использованием суммы общих инвестиций (IC), т. е. планируемых вложений по всем сценариям развития и доли $(d)$ инвестиций в сценарий $n$. 
Таблица 25

Когнитивная карта распределения инвестиций по сценариям развития и типам инвестиционной политики

\begin{tabular}{|c|c|c|c|c|c|}
\hline 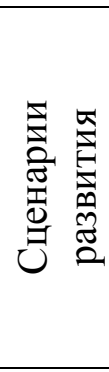 & $\begin{array}{c}\text { Краткая характеристика варианта } \\
\text { развития }\end{array}$ & 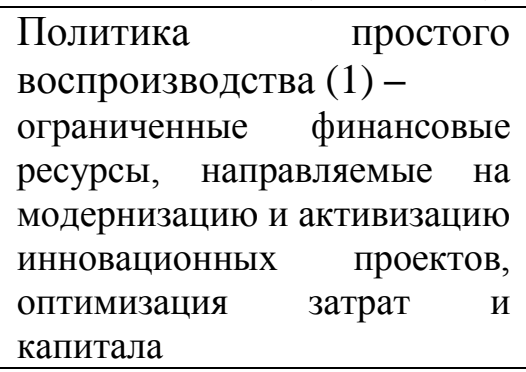 & $\begin{array}{l}\text { Политика умеренного } \\
\text { роста (2) - } \\
\text { инвестиции направлены на } \\
\text { расширение деятельности, на } \\
\text { качественное обновление } \\
\text { экономики, реинвестирование } \\
\text { в восстановление и т. д. }\end{array}$ & $\begin{array}{l}\text { Политика активного } \\
\text { инвестирования (3) - } \\
\text { инвестиции в поиск } \\
\text { новых направлений, } \\
\text { расширение } \\
\text { производства, повышение } \\
\text { конкурентных позиций на } \\
\text { основе инноваций }\end{array}$ & $\begin{array}{l}\text { Распреде- } \\
\text { ление } \\
\text { инвестиций } \\
\text { по сценариям } \\
\text { развития }\end{array}$ \\
\hline 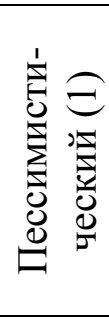 & $\begin{array}{l}\text { Углубление социального неравенства, } \\
\text { высокие ставки налогов, низкие тем- } \\
\text { пы экономического роста, увеличе- } \\
\text { ние теневого сектора экономики, вы- } \\
\text { сокая социальная напряженность. } \\
\text { Характерны тенденции ухудшения } \\
\text { ПС. Критический уровень ЭЭБ } \\
\end{array}$ & $K_{11}=R_{11} d_{1} I C$ & $K_{12}=R_{12} d_{1} I C$ & $K_{13}=R_{13} d_{1} I C$ & $\begin{array}{l}K_{1 i}=\sum_{1}^{l} R_{1 i} d_{1} I C \\
(\mathrm{i}=\text { от } 1 \text { до } 3)\end{array}$ \\
\hline 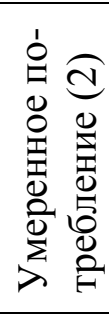 & $\begin{array}{l}\text { Умеренное потребление. Расширение } \\
\text { возможностей роста качества ОП за } \\
\text { счет новых технологий и научно- } \\
\text { технических решений. Снижение } \\
\text { темпов потребления невозобнов- } \\
\text { ляемых природных ресурсов. Низкий } \\
\text { уровень ЭЭБ }\end{array}$ & $K_{21}=R_{21} d_{2} I C$ & $K_{22}=R_{22} d_{2} I C$ & $K_{23}=R_{23} d_{2} I C$ & $\begin{array}{l}K_{2 i}=\sum_{1}^{i} R_{2 i} d_{2} I C \\
(\mathrm{i}=\text { от } 1 \text { до } 3)\end{array}$ \\
\hline 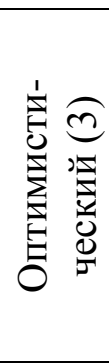 & $\begin{array}{l}\text { Сокращение } \\
\text { неравенства, высокий уровень жизни } \\
\text { всего населе-ния. Незначительный } \\
\text { экономический рост за счет } \\
\text { экстенсивных факторов, улучшение } \\
\text { всех показателей, характеризующих } \\
\text { качество жизни и ОП. Нормальный } \\
\text { уровень ЭЭБ }\end{array}$ & $K_{31}=R_{31} d_{3} I C$ & $K_{32}=R_{32} d_{3} I C$ & $K_{33}=R_{33} d_{3} I C$ & $\begin{array}{l}K_{3 i}=\sum_{1}^{l} R_{3 i} d_{3} I C \\
(\mathrm{i}=\text { от1 до } 3)\end{array}$ \\
\hline & $\begin{array}{l}\text { Распределение } \text { инвестиций по } \text { вариантам ИП в соответствии с } \\
\text { выделенными сценариями развития }\end{array}$ & $\begin{array}{c}K_{n 1}=\sum_{1}^{n} R_{n 1} d_{n} I C \\
(\mathrm{n}=\text { от } 1 \text { до } 3)\end{array}$ & $\begin{array}{c}K_{n 2}=\sum_{1}^{n} R_{n 2} d_{n} I C \\
(\mathrm{n}=\text { от } 1 \text { до } 3)\end{array}$ & $\begin{aligned} K_{n 3} & =\sum_{1}^{n} R_{n 3} d_{n} I C \\
(\mathrm{n} & =\text { от } 1 \text { до } 3)\end{aligned}$ & $K_{n i}=\sum_{1}^{i} R_{n i} d_{n} I C$ \\
\hline
\end{tabular}


Экспертная карта оценки коэффициента значимости

\begin{tabular}{|c|c|c|c|c|c|c|}
\hline \multirow[t]{2}{*}{ Сценарии } & \multicolumn{2}{|c|}{$\begin{array}{l}\text { Политика простого } \\
\text { воспроизводства (1) }\end{array}$} & \multicolumn{2}{|c|}{$\begin{array}{c}\text { Политика умеренного } \\
\text { роста (2) }\end{array}$} & \multicolumn{2}{|c|}{$\begin{array}{c}\text { Политика активного } \\
\text { инвестирования (3) }\end{array}$} \\
\hline & $\begin{array}{c}\text { расчет- } \\
\text { ная } \\
\text { оценка } \\
\text { ЭЭБ }\left(S_{\partial}\right)\end{array}$ & $\begin{array}{c}\text { отношение } \\
\text { расчетной } \\
\text { оценки К } \\
\text { текущей }\left(R_{n 1}\right)\end{array}$ & $\begin{array}{c}\text { расчет- } \\
\text { ная } \\
\text { оценка } \\
\text { ЭЭБ }\left(S_{\partial}\right)\end{array}$ & $\begin{array}{c}\text { отношение } \\
\text { расчетной } \\
\text { оценки к } \\
\text { текущей }\left(R_{n 2}\right)\end{array}$ & $\begin{array}{c}\text { Расчет } \\
\text { ная } \\
\text { оценка } \\
\text { ЭЭБ }\left(S_{\partial}\right)\end{array}$ & $\begin{array}{c}\text { отношение } \\
\text { расчетной } \\
\text { оценки к } \\
\text { текущей }\left(R_{n 3}\right)\end{array}$ \\
\hline Пессимистический (1) & $S_{\partial}$ & $R_{1,1}=S_{\partial} / S_{1,1}$ & $S_{\partial}$ & $R_{1,2}=S_{\partial} / S_{1,2}$ & $S_{\partial}$ & $R_{1,3}=S_{\partial} / S_{1,3}$ \\
\hline $\begin{array}{l}\text { Умеренное потребле- } \\
\text { ние (2) }\end{array}$ & $S_{\partial}$ & $R_{2,1}=S_{\partial} / S_{2,1}$ & $S_{\partial}$ & $R_{2,2}=S_{\partial} / S_{2,2}$ & $S_{\partial}$ & $R_{2,3}=S_{\partial} / S_{2,3}$ \\
\hline Оптимистический (3) & $S_{\partial}$ & $R_{3,1}=S_{\partial} / S_{3,1}$ & $S_{\partial}$ & $R_{3,2}=S_{\partial} / S_{3,2}$ & $S_{\partial}$ & $R_{3,3}=S_{\partial} / S_{3,3}$ \\
\hline
\end{tabular}

В силу отсутствия индикаторов, информативных с точки зрения выработки инвестиционной политики, при расчете потребности в капитале вводятся коэффициенты значимости ЭЭС (Rni). Коэффициенты определяются путем составления карты (табл. 28) и учитывают сводную оценку расчетного (допустимого) уровня ЭЭБ $(S)$ и текущую сводную оценку ЭЭБ, определенную для каждого типа сценария и вида инвестиционной политики.

Коэффициенты значимости рассчитываются с целью обоснования выбора $i$ типа инвестиционной политики при заданном $n$-м сценарии социальноэкономического развития территории.

Разработка когнитивных карт призвана обеспечивать трансляцию информации об экологической ситуации в регионе в систему выбора типа инвестиционной политики, формируемой в разрезе сценариев социальноэкономического развития, с целью оптимального распределения сумм бюджетных инвестиций и обоснования альтернатив экологически допустимого экономического роста территории.

Выполненная диагностика в разрезе инерционного и инновационного сценариев до $t_{1+i}$ периода дает возможность на основе полученных сводных допустимых оценок состояния ЭЭБ $(S)$ сформировать когнитивную и экспертную карты (табл. 27, 28) для каждого типа сценария и вида инвестиционной политики и текущей сводной оценки ЭЭБ территории. 
Таблица 27

Прогнозная оценка по инновационному и инерционному сценариям

\begin{tabular}{|c|c|c|c|c|c|c|c|c|}
\hline \multirow[b]{2}{*}{ Тип сценария } & \multicolumn{4}{|c|}{ Оценка* $\left(t_{1}\right)$} & \multicolumn{4}{|c|}{ Оценка* $\left(t_{1+i}\right)$} \\
\hline & \begin{tabular}{|l} 
Простое \\
воспро- \\
извод- \\
ство
\end{tabular} & $\begin{array}{l}\text { Отношение } \\
\text { допустимой } \\
\text { оценки к } \\
\text { гекущей }(R)\end{array}$ & $\begin{array}{l}\text { Расши- } \\
\text { ренное } \\
\text { воспро- } \\
\text { извод- } \\
\text { ство }\end{array}$ & $\begin{array}{l}\text { Отноше- } \\
\text { ние допус } \\
\text { тимой } \\
\text { оценки } \\
\text { к теку- } \\
\text { щей }(R)\end{array}$ & $\begin{array}{l}\text { Простое } \\
\text { воспро- } \\
\text { извод- } \\
\text { ство }\end{array}$ & $\begin{array}{l}\text { Отноше- } \\
\text { ние допус- } \\
\text { тимой } \\
\text { оценки к } \\
\text { текущей }(R)\end{array}$ & \begin{tabular}{|l} 
Расшир \\
енное \\
воспро \\
извод- \\
ство
\end{tabular} & $\begin{array}{l}\text { Отноше- } \\
\text { ние допус- } \\
\text { тимой } \\
\text { оценки к } \\
\text { теку- } \\
\text { цей }(R)\end{array}$ \\
\hline $\begin{array}{c}\text { Инерционный } \\
\text { (пессимистичес- } \\
\text { кий) }\end{array}$ & 7,63 & 1,1 & 8,08 & 1,04 & 7,92 & 1,06 & 8,19 & 1,02 \\
\hline $\begin{array}{c}\text { Инновацион- } \\
\text { ный } \\
\text { (оптимистичес- } \\
\text { кий) }\end{array}$ & 7,87 & 1,06 & 8,48 & 0,99 & 7,85 & $\mathbf{1 , 0 7}$ & 10,19 & 0,82 \\
\hline
\end{tabular}

* - сводная оценка допустимого уровня ЭЭБ для Свердловской области составляет 8,38.

Общий объем инвестиций, определенный по каждому сценарию (табл. 27), корректируется на коэффициент значимости в том случае, если его величина больше единицы $(R \geq 1)$ и остается без изменения, если коэффициент меньше единицы (условно его влияние на результат принимается равным 1).

Таблица 28

Когнитивная карта распределения инвестиций, млн. руб.

\begin{tabular}{|c|c|c|c|c|c|c|}
\hline \multirow[t]{2}{*}{ Сценарии развития } & \multicolumn{2}{|c|}{$\begin{array}{c}\text { Краткая характеристика } \\
\text { варианта развития }\end{array}$} & \multicolumn{2}{|c|}{$\begin{array}{c}\text { Политика простого } \\
\text { воспроизводства - }\end{array}$} & \multicolumn{2}{|c|}{$\begin{array}{c}\text { Политика активного } \\
\text { инвестирования }\end{array}$} \\
\hline & & & $t_{1}$ & $t_{1+i}$ & $t_{1}$ & $\mathrm{t}_{1+i}$ \\
\hline $\begin{array}{c}\text { Инерционный } \\
\text { (пессимистический) }\end{array}$ & $\begin{array}{l}\text { Критический } \\
\text { ЭЭБ }\end{array}$ & уровень & 5226 & 6296 & 5436 & 6664 \\
\hline $\begin{array}{c}\text { Инновационный } \\
\text { (оптимистический) }\end{array}$ & $\begin{array}{l}\text { Нормальный } \\
\text { ЭЭБ }\end{array}$ & уровень & 5927 & 7009 & 6430 & 7533 \\
\hline
\end{tabular}

Примечание: объем инвестиций, определенный по сценариям корректируется на коэффициент значимости, если его величина больше единицы $(R \geq 1)$ и остается без изменения, если - меньше единицы (принимается, что влияние $R$ равно 1 ).

Организация передачи и учета результатов оценки ЭЭБ в систему принятия управленческих решений социально-экономического развития территории экологически важной информации рассматривается как механизм выбора инвестиционной политики, реализующий экологически безопасное хозяйственное развитие региона.

\section{Вопросы и задания для самоконтроля}

1. Схема взаимодействия систем принятия стратегических управленческих решений и регулирования инвестиционного климата региона. 
2. Раскройте содержание процедуры формирования когнитивных карт.

3. Опишите процесс формирования когнитивных карт распределения инвестиций.

4. Характеристика экспертной карты оценки коэффициентов значимости.

5. Формирование прогнозной оценки инвестиций по инновационному и инерционному сценариям.

Рекомендуемая литература:

1. Белик И. С. Влияние эколого-экономической безопасности на выбор стратегических инвестиционных решений / И. С. Белик. Екатеринбург : УГТУ-УПИ, 2008. $117 \mathrm{c}$.

2. Белик И. С. Экологические приоритеты инвестиционной активности территории / И. С. Белик, Н. В. Стародубец. Екатеринбург: УГТУ-УПИ, 2009. 173 с.

3. Мекуш Г. Е. Экологическая политика и устойчивое развитие: анализ и методические подходы / Г. Е. Мекуш; под ред. С. Н. Бобылева; Кемеровский гос. ун-т. М. : Экономика, 2011. 255 с.

\section{2. Отбор инвестиционных проектов по критериям}

\section{эколого-экономической безопасности}

Для обоснования инвестирования за счет такого источника как бюджетное финансирование природоохранных проектов следует включать в систему отбора проектов в качестве обязательной процедуру ранжирования по приоритетным критериям. Функционально она имеет направленность, связанную с выявлением проектов, имеющих обязательную коммерческую выгоду, определенную с учетом всех негативных и положительных социальноэкономических и экологических последствий реализации проектного решения.

Приоритетныли в системе ранжирования являются не только формальные критерии отбора инвестиционных проектов, предусмотренные методиками оценки инвестиций, но и дополнительные, имеющие равнозначное для системы значение.

При принятии решения о поддержке инвестиционных проектов, имеющих природоохранную направленность, экономическая эффективность которых, как правило, незначительна (капиталоемкие и малоприбыльные), возникает вопрос их непривлекательности для инвесторов. Ранее попытки разрешить проблему большей части сводились к предложениям о включении в результаты проекта показателей предотвращенного экологического ущерба. 


\section{Справка}

С методологической точки зрения данное положение не требует обоснования, так как платежи за загрязнение ОС, имеющие компенсационный характер, действующими методическими рекомендациями рекомендованы $\kappa$ включению в состав денежных потоков. Однако на сегодняшний день ситуация такова, что ставки платежей за загрязнение ОС невысоки и учет выгод от их снижения не является решающим фактором при обосновании инвестиций в миллионы рублей. Вследствие этого при оценке коммерческой эффективности природоохранных проектов в лучшем случае отмечается положительный (или отличный от нуля) эффект, а результативными они становятся лишь при включении предотвращенного экологического ущерба в доходную часть проекта.

В методическом плане данная проблема обозначена, но на практике не наблюдается положительных ожидаемых результатов. Поэтому в интересах инвесторов и региональных органов планирования и управления в инвестиционной сфере для обоснования выбора и поддержки финансирования проектов предлагается ввести процедуру ранжирования по приоритетным критериям и сравнительной рейтинговой оценки.

\section{Справка}

Инвестиционный природоохранный проект [15] - это системно ограниченный и законченный комплекс мероприятий, документов и работ, общественным результатом инвестирования в который является решение экологических проблем, а материально-вещественным результатом - новые или реконструируемые основные фонды природоохранного назначения

Традиционно отбор проектов, поддерживаемых и финансируемых из бюджетных и внебюджетных фондов, а также на уровне хозяйствующих субъектов, осуществляется на основе формальных критериев. В ходе скрининга проекты подвергаются инвестиционному анализу на соответствие уровню риска, выбранной ставке дисконтирования и др. Для оценки влияния экологического фактора на выбор объектов инвестирования предлагается в ходе данной процедуры выполнять анализ проектов с привлечением дополнительных критериев отбора, используемых затем и для сравнительной рейтинговой оценки. Собственно дополнительные критерии, установленные в 
системе ранжирования, должны отвечать требованиям, которые ограничиваются условием полноты оченки эколого-экономических последствий реализации проекта и учета экологических приоритетов территории. Выполнение этого условия необходимо для инвестиционных проектов любого типа, включая природоохранные.

Рейтинг инвестиционных проектов по стандартным и нестандартным критериям применяется после этапа анализа проектов и выполняется в соответствии со следующим алгоритмом:

- разрабатывается исходная матрица (табл. 29), в которой по строкам представляются показатели, полученные на основе стандартных и дополнительных критериев, а по столбцам - расчетные значения по каждому анализируемому проекту;

Таблица 29

Матрица нормированных значений показателей по анализируемым проектам

\begin{tabular}{|c|c|c|c|c|c|c|c|}
\hline \multirow{2}{*}{$\begin{array}{c}\text { Показатель } \\
\text { Чистый дисконтированный доход (NPV) }\end{array}$} & \multicolumn{3}{|c|}{$\begin{array}{l}\text { Нормированное } \\
\text { значение показателей } \\
\text { по проектам } \\
\end{array}$} & \multirow[t]{2}{*}{$\begin{array}{r}\text { Балл } \\
(\xi i) \\
\end{array}$} & \multicolumn{3}{|c|}{$\begin{array}{c}\text { Рейтинговая оценка } \\
\text { по проектам }\end{array}$} \\
\hline & $k_{N P V I}$ & $\cdots$ & $k_{N P V n}$ & & $P_{N P V I}$ & $\cdots$ & $P_{N P V n}$ \\
\hline Внутренняя норма доходности (IRR) & $k_{\text {IRRI }}$ & $\cdots$ & $k_{\text {IRRn }}$ & & $P_{\text {IRRI }}$ & $\ldots$ & $P_{\text {IRRn }}$ \\
\hline $\begin{array}{l}\text { Модифицированный срок окупаемости } \\
\text { капвложений }(P P)\end{array}$ & $k_{\mathrm{PP} 1}$ & $\ldots$ & $k_{P P n}$ & & $P_{P P 1}$ & $\cdots$ & $P_{P P n}$ \\
\hline Снижение платежей за загрязнение (p) & $k_{P 1}$ & $\ldots$ & $k_{P n}$ & & $P_{P 1}$ & $\ldots$ & $P_{P n}$ \\
\hline $\begin{array}{l}\text { Размер предотвращенного ущерба в } \\
\text { стоимостном выражении }\end{array}$ & $k_{U I}$ & ... & $k_{U n}$ & & $P_{U 1}$ & $\cdots$ & $P_{U n}$ \\
\hline $\begin{array}{l}\text { Эластичность выбрросов (сбросов) по } \\
\text { объему производства }\end{array}$ & $k_{E l}$ & .. & $k_{E n}$ & & $P_{E l}$ & $\cdots$ & $P_{E n}$ \\
\hline $\begin{array}{l}\text { Отношение предотвращенного ущерба } \\
\text { к затратам по проекту }\end{array}$ & $k_{R U 1}$ & $\cdots$ & $k_{R U n}$ & & $P_{R U 1}$ & $\cdots$ & $P_{R U n}$ \\
\hline $\begin{array}{l}\text { Сокращение риска здоровью населения } \\
\text { от улучшения качества }{ }^{*} \text { OC }\end{array}$ & $k_{P R I}$ & $\cdots$ & $k_{P R n}$ & & $P_{P R I}$ & $\cdots$ & $P_{P R n}$ \\
\hline $\begin{array}{l}\text { Отнотение бюджетного эффекта } к \\
\text { затратам по проекту* }\end{array}$ & $k_{R B 1}$ & $\ldots$ & $k_{R B n}$ & & $P_{R B 1}$ & $\cdots$ & $P_{R B n}$ \\
\hline Сводная оценка по проекту & - & - & - & - & $P$ & $\cdots$ & $P$ \\
\hline
\end{tabular}

*Курсивом выделены показатели, предлагаемые для включения в систему рейтинга

- экспертным путем определяется значимость каждого формального и неформального показателя в баллах ( $\xi i)$; 
- на основе матрицы влияния создается «матрица нормированных значений». Нормированное значение показателя (kij) определяется путем деления расчетной величины, полученной по каждому проекту, на лучшее;

- выполняется ранжирование проектов с использованием рейтинговой оценки (

$$
P j=\sqrt{\sum \xi i(1-k i j)^{2}},
$$

где $\xi i-$ весовой коэффициент показателя, определяемый экспертным путем;

Выражение (15) показывает, что нормированные значения, полученные по каждому проекту, дополненные до единицы и возведенные в квадрат, взвешиваются на величину экспертной оценки «весомости» критерия, и складываются по всем показателям проекта с последующим извлечением из суммы квадратного корня, дающего среднюю величину сравнительной оценки;

- определяется сводная рейтинговая оценка путем суммирования частных оценок $P j$ по всем рассматриваемым проектам;

- рейтинг проектов выполняется по сводной оценке в порядке ее убывания.

\section{Bblвod}

Методика отбора инвестиционных проектов в процедуре рейтинга по эколого-экономическим и стандартным критериям коммерческой эффективности, позволяет повысить объективность выбора проектов и стимулировать процесс инвестирования в природоохранную сферу.

Особенность инвестиционных природоохранных проектов проявляется в снижении экологической нагрузки и росте общественной полезности. То есть тех категорий, экономические выгоды от изменения состояния которых определить непросто, и их положительные результаты чаще всего отдалены во времени, а проявления зачастую не ограничиваются рамками одного региона.

Если проекты подобного типа связаны с внедрением в производство чистых и ресурсосберегающих технологий, это приводит не только к экологическому, но и экономическому эффекту, проявляющемуся в снижении 
издержек и/или увеличении объема производства (например, за счет использования отходов), в этом случае их коммерческая эффективность очевидна. Конечно, она может быть ниже, чем у других, например инновационных проектов, но если природоохранные проекты будут иметь государственную поддержку, одно это условие уже сделает их привлекательными для инвесторов.

В настоящее время коммерческая оценка инвестиционных проектов осуществляется по основным (формальным) критериям, а именно:

- чистая приведенная стоимость (NPV);

- индекс рентабельности инвестиций $(I R)$;

- срок окупаемости инвестиционных затрат $(P P)$;

- внутренняя норма прибыли $(I R R)$ и др.

Для инвестиционных проектов, осуществление которых связано с воздействием на ОС, следует учитывать в качестве npuорuтеmных предотвращченный ущзерб и производные от него показатели.

Реализовать данный подход можно посредством включения в состав денежных потоков всех элементов ущерба, имеющих прямое и косвенное к нему отношение, выраженных в виде количественных оценок:

- изменение платежей за загрязнение ОС;

- выплаты компенсационного характера за нанесенный ущерб здоровью населения, обусловленный воздействием загрязняющих веществ (потеря трудоспособности, снижение дохода в результате болезни);

- удорожание стоимости лечения;

- удорожание затрат на содержание и эксплуатацию экологически опасного оборудования и техники (с использованием коэффициента удорожания);

- учета доли расширения рынка сбыта и увеличения спроса за счет применения новых, более экологически эффективных технологий, обеспечивающих стабильное высокое качество продукции и т. д. 
Сравнительная рейтинговая оцеенка выполняется после проведения анализа инвестиционных проектов с использованием показателей, представляющих наибольший интерес для инвесторов и для системы поддержания благоприятного инвестиционного климата.

Насколько более обоснованным становится решение, связанное с отбором инвестиционных проектов по приоритетным показателям и применением сравнительной рейтинговой оценки, можно проследить на примере.

\section{Пример}

Модельной территорией является муниципальное образование Свердловской области г. Сухой Лог и его градообразующее предприятие цементный завод (ОАО «Сухоложскцемент»). Цементный завод является основным источником загрязнения атмосферного воздуха выбросами цементной пыли (табл. 30).

Таблица 30

Динамика производства цемента ОАО «Сухоложскцемент», тыс. т

\begin{tabular}{|l|c|c|c|c|c|c|c|c|c|}
\hline \multicolumn{1}{|c|}{ Периоды } & 1 & 2 & 3 & 4 & 5 & 6 & 7 & 8 & 9 \\
\hline $\begin{array}{l}\text { Объем } \\
\text { производства }\end{array}$ & 1004 & 1201 & 1758 & 1814 & 1834 & 1994 & 2056 & 2234 & 3584 \\
\hline
\end{tabular}

ОАО «Сухоложскцемент» - крупнейший завод Волжско-Уральской зоны. Доля предприятия в формировании местного бюджета превышает 38 \%. За последние 9 лет наблюдается положительная динамика производства.

\section{Справка}

ОАО «Сухоложскцемент» относится к предприятиям строительного комплекса, наносящим значительный ущерб окружающей среде в форме: загрязнения водных объектов сточными водами, атмосферного воздуха выбросами цементной пыли, размещением отходов производства - почве. Муниципальное образование «город Сухой Лог», в котором расположено предприятие, входит в число 13 территорий с наиболее неблагоприятной экологической обстановкой, наряду с МО «город Нижний Тагил», «город Асбест», «город Екатеринбург», «город Серов». И хотя «город Сухой Лог» не включен в список самых грязных городов области, ситуация на территории остается не вполне благополучной из-за основного источника загрязнения - предприятия ОАО «Сухоложскцемент». Суммарный показатель качества атмосферного воздуха не соответствует допустимому 
уровню, что влечет за собой увеличение риска неблагоприятного влияния на здоровье населения. По этой причине актуальной задачей для ОАО «Сухоложскцемент» является проведение инвестиционной политики, взаимоувязанной с природоохранной деятельностью.

Предприятие служит источником выбросов оксида углерода, диоксида азота, легколетучих органических соединений и входит в четверку предприятий строительного комплекса Свердловской области, вносящих основной вклад в загрязнение атмосферного воздуха.

В настоящий момент инвестиционная программа развития компании формируется практически без учета природоохранных мероприятий. Обоснованием включения природоохранных проектов в инвестиционный бюджет компании могут служить результаты ранжирования (по приоритетным критериям) и сравнительной рейтинговой оценки.

Предварительный анализ инвестиционной и природоохранной программ предприятия с применением ранжирования проектов по приоритетным критериям, в том числе и дополнительным, позволяет сделать выбор в пользу трех мероприятий (табл.31), имеющих природоохранную направленность.

Таблица 31

Матрица исходных данных

\begin{tabular}{|c|c|c|c|c|}
\hline \multirow{2}{*}{ Показатель } & \multicolumn{3}{|c|}{ Проекты } & \multirow{2}{*}{$\begin{array}{l}\text { Лучшее } \\
\text { значение }\end{array}$} \\
\hline & 1 & 2 & 3 & \\
\hline 1. $N P V$, руб. & 146445,7 & 3755746,3 & 1306974,3 & 3755746,3 \\
\hline 2. $P P$ & 7 & 4 & 3,8 & 3,8 \\
\hline 3. IRR & 24,12 & 45,46 & 46,74 & 46,74 \\
\hline 4. Уровень снижения платежей, & 3,5 & 1,76 & 0 & 3,5 \\
\hline 5. Сокращение ущерба, руб. & 36396 & 18198 & 0 & 36396 \\
\hline $\begin{array}{l}\text { 6. Сокращение массы выбросов } \\
\text { (сбросов), \% }\end{array}$ & 2,32 & 1,16 & 0 & 2,32 \\
\hline $\begin{array}{l}\text { 7. Отношение предотвращен- } \\
\text { ного ущерба к затратам, \% }\end{array}$ & 6 & 0,4 & 0 & 6 \\
\hline $\begin{array}{l}\text { 8. Отношение NPV к предот- } \\
\text { вращенному ущербу, \% }\end{array}$ & 4 & 206 & - & 206 \\
\hline
\end{tabular}

Сравниваемые мероприятия проходят процедуру рейтинговой оценки с целью обоснования включения в инвестиционную программу предприятия. В соответствии с принципами природоохранной политики и условиями 
ограниченности инвестиционных ресурсов в качестве дополнительных используются критерии, отражающие экологическую эффективность проектов, т. е. сокращение воздействия на ОС (эмиссии выбросов) и величину предотвращенного ущерба (в денежных потоках отражается через платежи за загрязнение). Далее экспертным путем определяется значимость каждого формального и неформального показателя в баллах по рассматриваемым мероприятиям (табл. 32).

Таблица 32

Оценка показателей в баллах

\begin{tabular}{|l|l|l|l|l|l|l|l|l|}
\hline Номер показателя по проекту & 1 & 2 & 3 & 4 & 5 & 6 & 7 & 8 \\
\hline Балл & 3 & 1 & 2 & 1 & 2 & 3 & 2 & 2 \\
\hline
\end{tabular}

Оценку целесообразно выполнять по трехбалльной шкале, в которой балл, равный 3, обозначает наиболее значимый как формальнылй, так и дополнительный показатель, 1 - наименее значимый.

В расчетах дополнительный критерий под номером «6» (сокращение массы выбросов) оценивается по максимальной шкале с учетом того, что в системе экологической безопасности он является одним из основных параметров.

Следуя порядку схемы рейтинга на основе матрицы исходных данных и экспертных оценок значимости, строится матрица нормированных значений показателей (табл. 33).

Таблица 33

Матрица нормированных показателей

\begin{tabular}{|c|c|c|c|}
\hline \multirow{2}{*}{ Показатель } & \multicolumn{3}{|c|}{ Проекты } \\
\hline & 1 & 2 & 3 \\
\hline 1. $N P V$ & 0,04 & 1,00 & 0,35 \\
\hline 2. $P P$ & 1,84 & 1,05 & 1,00 \\
\hline 3. IRR & 0,52 & 0,97 & 1,00 \\
\hline 4. Уровень снижения платежей & 1,00 & 0,50 & 0,00 \\
\hline 5. Сокращение ущерба & 1,00 & 0,50 & 0,00 \\
\hline 6. Сокращение массы выбросов (сбросов) & 1,00 & 0,50 & 0,00 \\
\hline $\begin{array}{l}\text { 7.Отношение предотвращенного ущерба к затратам по } \\
\text { проекту }\end{array}$ & 1,00 & 0,07 & 0,00 \\
\hline 8.Отношение $N P V$ к предотвращенному ущербу по проекту & 0,02 & 1 & - \\
\hline
\end{tabular}


Нормирование осуществлялось путем деления каждого показателя на лучший, зафиксированный в матрице исходных данных. Расчетные значения сводятся в таблицу, представляемую в форме матрицы (см. табл. 33).

После расчета нормированных значений показатели взвешиваются на коэффициент, характеризующий значимость каждого параметра по степени его влияния на общую оценку (см. табл.33), суммируются с использованием формулы $P j=\sqrt{\sum \xi i(1-k i j)^{2}}$ и представляются в виде итоговой оценки (табл.34).

Таблица 34

Итоговая рейтинговая оценка проектов

\begin{tabular}{|c|c|c|c|c|}
\hline \multirow[b]{2}{*}{ Показатель } & \multicolumn{3}{|c|}{ Проекты } & \multirow[b]{2}{*}{ Балл } \\
\hline & 1 & 2 & 3 & \\
\hline 1. $N P V$ & 1,66 & 0,00 & 1,13 & 3 \\
\hline 2. $P P$ & 0,84 & 0,05 & 0,00 & 1 \\
\hline 3. IRR & 0,68 & 0,04 & 0,00 & 2 \\
\hline 4. Уровень снижения платежей & 0,00 & 0,50 & 1,00 & 1 \\
\hline 5. Сокращение ущерба & 0,00 & 0,71 & 1,41 & 2 \\
\hline 6. Сокращение массы выбросов & 0,00 & 0,87 & 1,73 & 3 \\
\hline $\begin{array}{l}\text { 7. Отношение предотвращенного ущерба к } \\
\text { затратам по проекту }\end{array}$ & 0,00 & 1,31 & 1,41 & 2 \\
\hline 8. Отношение $N P V /$ затратам по проекту & 1,38 & 0 & 0,00 & 2 \\
\hline Итоговая оценка & 4,56 & 3,48 & 6,68 & \\
\hline
\end{tabular}

Таким образом, итоговая рейтинговая оценка проектов формируется в виде суммы частных оценок по каждому мероприятию. В заключение мероприятия ранжируются в порядке убывания показателя рейтинговой оценки (табл. 35).

Таблица 35

Итоговое ранжирование мероприятий

\begin{tabular}{|c|c|}
\hline Наименование проекта & Рейтинговая оценка \\
\hline Проект 2 & 1 место \\
\hline Проект 1 & 2 место \\
\hline Проект 3 & 3 место \\
\hline
\end{tabular}

Ранжирование природоохранных проектов по приоритетным экологоэкономическим признакам, включающим как коммерческие, так и дополнительные показатели эффективности проектов, с получением итоговой рейтинговой оценки, дает возможность определить приоритетные проекты и включить в инвестиционную программу и бюджет развития предприятия. 


\section{Справка [6]}

В примере природоохранным мероприятием с лучшей рейтинговой оценкой стал проект (2) - «Установка газоанализатора». Данное мероприятие имело очень высокую коммерческую эффективность (см. табл. 33), которая достигалась за счет улучшения качества продукции предприятия и увеличения дохода от продаж тампонажного цемента. При этом показатели $I R R$ и $P P$ - не самые лучшие из всех рассматриваемых, однако соответствуют условиям эффективности. Собственно мероприятие, имеющее удовлетворительные значения коммерческой эффективности и предполагающее снижение выбросов и соответственно платы за выбросы и величины экологического ущерба, проявило себя при рейтинге как наиболее действенное с точки зрения доходности и экологических результатов. И хотя экологические преимущества у него ниже, чем у Проекта (1) «Установка системы орошения», его суммарный рейтинг лучше из-за экономических выгод.

Проект - «Установка системы орошения» - находится на втором месте в рейтинге, несмотря на то, что имеет самые низкие показатели коммерческой эффективности (см.табл.29). Высокий рейтинг проекта достигается за счет учета как равноценных дополнительных показателей величины снижения массы выбросов (самое значительное сокращение), поэтому у него лучшие результаты по размеру предотвращенного ущерба и платы за выбросы.

Проект (3) - «Строительство локальной очистной установки» также имеет достаточно высокие показатели коммерческой эффективности (см.табл.31), однако проектные решения не вызывают сокращения экологического ущерба, поэтому вопрос о его включении в текущий инвестиционный бюджет компании менее актуален и может быть отложен на последующий бюджетный период.

Рекомендации по включению первых двух проектов в инвестиционную программу и соответственно бюджет развития опираются на результаты их коммерческой и экологической эффективности. Однако проектам подобного типа свойственен и еще один вид эффекта - социальный.

Социальная эффективность проектов проявляется в снижении техногенной нагрузки на территорию и последующем улучшении качества окружающей природной среды, изменении ее влиянии на здоровье населения.

Результаты расчетов снижения уровня заболеваемости от сокращения выбросов цементной пыли показывают, что природоохранные мероприятия, предлагаемые к включению в инвестиционную программу ОАО 
«Сухоложскцемент», имеют существенный социальный эффект, т. е. позволяют снизить потери территории от действия мелкодисперсной пыли на население.

Достигаемый сочиальный эффект является дополнительным фактором, свидетельствующим о необходимости включения природоохранных мероприятий в инвестиционную программу предприятия. Значительный социальный эффект делает возможным осуществление природоохранных мероприятий за счет средств государственных внебюджетных фондов, поскольку предприятие получает возможность обосновать заявку на финансирование природоохранных мероприятий, в том числе из государственных средств. Последнее обстоятельство значительно снижает цену авансированного капитала на инвестирование природоохранных мероприятий. В свою очередь снижение цены авансированного в проекты капитала позволяет существенно повысить их экономическую эффективность, поскольку основной показатель коммерческой эффективности $N P V$ является функцией ставки дисконтирования, определяемой часто на уровне цены авансированного капитала.

Ранжирование и сравнительная рейтинговая оценка природоохранных проектов, выполненных на основании ряда признаков, включающих как стандартные показатели коммерческой эффективности, так и показатели предотвращенного экологического ущерба, позволяют повысить объективность выбора проектов.

С учетом комплексной эколого-экономической оценки эффективности инвестиционных проектов государственная поддержка проектов, обладающих коммерческой и экологической эффективностью, выгодна не только инвесторам, но и территориальным органам планирования, занимающимся разработкой и реализацией региональных программ.

\section{Вопросы и задания для самопроверки}

1. Раскройте содержание формальных и дополнительных показателей оценки эффективности инвестиционных проектов.

2. Опишите процедуру рейтинга инвестиционных проектов.

3. Раскройте содержание методики отбора инвестиционных проектов по экологоэкономическим критериям. 


\section{Рекомендуемая литература}

1. Белик И. С. Влияние эколого-экономической безопасности на выбор стратегических инвестиционных решений / И. С. Белик. Екатеринбург : УГТУ-УПИ, 2008. $117 \mathrm{c}$.

2. Белик И. С. Экологические приоритеты инвестиционной активности территории / И. С. Белик, Н. В. Стародубец. Екатеринбург: УГТУ-УПИ, 2009. 173 с.

3. Мекуш Г. Е. Экологическая политика и устойчивое развитие: анализ и методические подходы / Г. Е. Мекуш; под ред. С. Н. Бобылева; Кемеровский гос. ун-т. М. : Экономика, 2011. 255 с.

\section{3. Эколого-экономическая эффективность производства, ориентирующая на выбор экологически безопасной \\ модели развития}

Теория эффективности четко разграничивает понятия эффекта и эффективности, понимая под первым физический результат хозяйственной деятельности (например, рост прибыли предприятия, прирост физического объема национального дохода в масштабе народного хозяйства и т. п.), под вторым - соотношение эффекта и вызвавших его затрат.

Эффективность, вскрывая характер причинно-следственных связей производства, отражает не сам результат, а то, как он был достигнут. Поэтому эффективность почти всегда характеризуется относительными показателями, сконструированными из различных характеристик (параметров) результата и затрат, что не исключает и системного рассмотрения абсолютных значений этих параметров. Однако, с развитием рыночных отношений и формированием российского фондового рынка, оценка эффективности производства требует ввода показателя, учитывающего рост рыночной стоимости предприятия (компании) от изменения технико-технологической основы производства.

Начиная с 90-х годов Россия активно включилась в международные конвенции и соглашения экологической направленности, что собственно поставило ее перед необходимостью следовать принципу «применения наилучшей из доступных технологий», сформулированному еще в 1983 г. 
специальной Директивой Европейской Комиссии, посвященной интеграции мер по предупреждению загрязнения ОС и экологическому контролю.

Соблюдение этого принципа на практике должно приводить к реализации наиболее эффективных вариантов природоохранной деятельности, а в долгосрочной перспективе к проблемам управления ресурсами, утилизации отходов, рационализации материальных и энергетических потоков в производственной кооперации.

К настоящему времени требование применения наилучшей из доступных технологий (НДТ) является составной частью природоохранного законодательства многих стран и международных конвенций, касающихся оценки экологического риска, предотвращения загрязнения ОС [40]. Однако для России переход к принципу применения НДТ осложнен тем, что отечественная промышленность в своей массе использует завершающие свой жизненный изикл природоохранную технику, процессы, оборудование, которые не обеспечивают высокий уровень защиты ОС.

Следование принципу «применение наилучших из доступных технологий» ставит перед необходимостью включения в состав оценки эффективности производства критерий «рост стоимости компании», т. е. ориентированности на будущие экономические выгоды. Доходный подход позволяет выделить следующие денежные потоки и выгоды, генерируемые применением НДТ [40]:

- наилучшие доступные технологии попадают в сферу объектов

- экологической сертификации и по этой причине предприятия, внедряющие НДТ, могут заявлять о соответствии производства статусу «экологически чистое производство». Маркировка производства по уровню «чистота технологии» на основе показателя «степень достижения нормативного состояния ОС» дает возможность ввести знак (лейбл) «экологически чистое производство» и идентифицировать его как нематериальный актив; 
- нематериальный актив с точки зрения доходного подхода в перспективе способен увеличивать чистый денежный поток компании за cчеm амортизациионных отчислений, что потенциально влияет на рост ее стоимости;

- представление составляющей «прирост нематериальных активов» в качестве результата от внедрения НДТ в системе показателей эффективности производства дает возможность полнее оценивать эффективность ее деятельности;

- внедрение

НДТ снижает трансакционные издержки (оппортунистического поведения, издержки измерения и т. д.) в ходе эксплуатации этих технологий.

Согласно МСФО 8 нематериальные активы, признаваемые в финансовой отчетности, оцениваются по расходам на их приобретение. В этой связи стоимость специального знака (эколейбл) может складываться как разность в затратах по наилучшей из доступных технологий и эксплуатируемой $в$ отрасли технологии, загрязняющей ОС. Признание знака «экологически чистое производство» нематериальным активом увеличивает стоимость активов компании, еe репутацию и в будущем возможности по получению дополнительной прибыли. Как следствие возрастает экономическая эффективность производства, что и должно найти отражение системе показателей эффективности.

Таким образом, модель оценки эколого-экономической эффективности производств, базирующихся на наилучших доступных технологиях, имеет следующий вид (модифицировано по [10]):

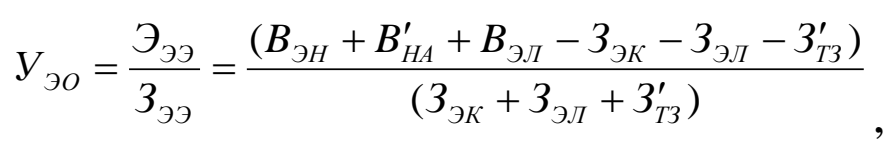

где $Э_{э э}-$ эколого-экономический эффект от внедрения проектов, содержащих экологические нововведения на предприятии-производителе и применении его продукции на предприятиях-потребителях;

$3_{э э}$ - эколого-экономические затраты от внедрения проектов, содержащих экологические нововведения на предприятии-производителе, и дополнительные затраты, возникающие в потреблении продукции его изготовления; 
$B_{\ni н}$ - экономическая выгода, полученная в результате внедрения проектов, содержащих нововведения экологического характера на предприятии-производителе и в применении его продукции на предприятиипотребителе;

$B_{\text {эл }}$ - предотвращенный экологический ущерб, полученный в результате внедрения проектов, содержащих нововведения экологического характера на предприятии-производителе и на предприятиях-потребителях его продукции;

$B_{H A}^{\prime}$ - экономические выгоды от использования экознака «экологически чистое производство» на предприятии-производителе;

$3_{э к}$ - затраты экономических ресурсов от внедрения проектов, содержащих нововведения экологического характера и дополнительные затраты, возникающие в потреблении его продукции;

$3_{\text {эл }}-$ дополнительные экологические затраты, связанные с внедрением проектов, содержащих нововведения экологического характера;

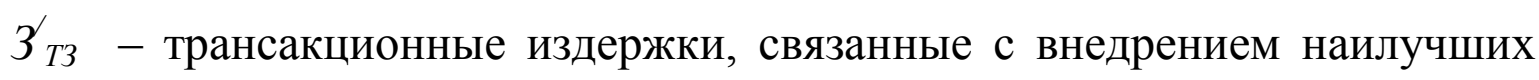
доступных технологий на предприятии.

По полноте учета результатов и затрат обобщенный показатель эффективности $\left(\boldsymbol{y}_{\text {эо }}\right)$ можно характеризовать как эколого-экономическую эффективность, поскольку он включает эффекты от эколого-экономических последствий производства в результате снижения нагрузок на ОС на всех составных частях жизненного цикла продукта.

Производства, применяющие наилучшие доступные технологии, имеют следующий потенциал роста эффективности производств [40]:

1. Производства, основанные на НДТ, повышают качество технологического процесса и технического уровня, что способствует увеличению организационного уровня производственной среды, разрешает минимизировать выход отходов (для применяемых технологических схем попрежнему характерна разомкнутость вещественно-энергетических циклов и образование огромного количества отходов, поступающих в природную среду). В итоге это приводит к значительному экономическому эффекту. 
2. Внедрение в производство наилучших доступных технологий предполагает комплексность использования ресурсов (большинство минеральных ресурсов, в первую очередь рудных природных ископаемых, являются комплексными, то есть содержащими, помимо основного вещества другие полезные для производства компоненты: металлы и неметаллы), то есть не только основного вещества, но и других полезных сопутствующих элементов на основе их полезности. Экономическая эффективность в этом случае обеспечивается сокращением расходов трудовых и материальных ресурсов, дополнительной прибылью от выпуска концентратов и расширения номенклатуры и др. Наряду с изменением прямых затрат и непосредственных результатов на производство единицы продукции появляется «сопряженный» экономический эффект от расширения сырьевой базы производства горнометаллургической промышленности.

3. Формирование и развитие производств, основанных на наилучших доступных технологиях, в своей основе направлено на сокращение ущерба, оказываемого на ОС, поэтому в механизм оценки эффективности включается экологическая составляющая, которая повышает совместную оценку результативности таких производств.

4. При внедрении принципиально новых технологических решений «рынок» выказывает следующую зависимость: влияние фирменных факторов (имидж фирмы, товарный знак, экологическая маркировка и др.) на изменение факторов конкурентоспособности компании (технологические различия в производстве продукции, частота появления новых технологий, число конкурирующих технологий). Влияние фирменных факторов является положительным в долгосрочной периоде и направлено на максимизацию прибыли, поэтому НДТ создают потенциал хозяйственного роста компании.

Таким образом, введение критерия «рост стоимости активов» компании в оценку эколого-экономической эффективности производства переносит проблему в практическую плоскость. Тем более такой подход важен для производств, являющихся экологически чистыли, чья рыночная стоимость сущеественно выще 
тех компаний, которые используют загрязняющие или допускающие загрязнение технологии.

Производства, организованные на базе наилучших доступных технологий, создают предпосылки для устойчивого (сбалансированного) развития предприятий и не допускают разрушения ПС, что отвечает идее совместимости экономического развития с требованием сохранения природного капитала. Поэтому НДТ представляют ту форму организации хозяйственной деятельности предприятия, которая обеспечивает ему переход к модели устойчивого развития.

Модель устойчивого развития предприятия заключается в способности хозяйственной системы предприятия поддерживать эколого-экономический режим функционирования, который рассматривает экологический ресурс как структурный элемент совокупного капитала и фактор экономического роста.

Организация производств, основным принципом которых является предотвращающие загрязнение ОС, вызывает изменения в структуре и технологическом уровне не только предприятия-производителя, но и во всей цепочке смежных сфер производства и потребления продукции (услуг). В итоге это стимулирует рост эффективности общественного производства и создает условия для дальнейшей экологизации экономики.

В настоящее время общепринятые подходы не рекомендуют включать экологический фактор в состав учитываемых компонентов развития, поскольку уровень хозяйственного роста промышленного предприятия и уровень экологической устойчивости ОС находятся в обратной зависимости. На практике это становится сдерживающим условием экономического роста промышленных компаний.

Однако реальное положение такового, что в оценках перспектив своего развития предприятия сталкиваются с недооценкой экономических показателей по экологическим критериям, тем самым завышают параметры роста и оптимистично отражают складывающуюся ситуацию.

Влияние оценки эффективности производства на процесс выбора и формализации стратегических решений представлен на рис. 12. 


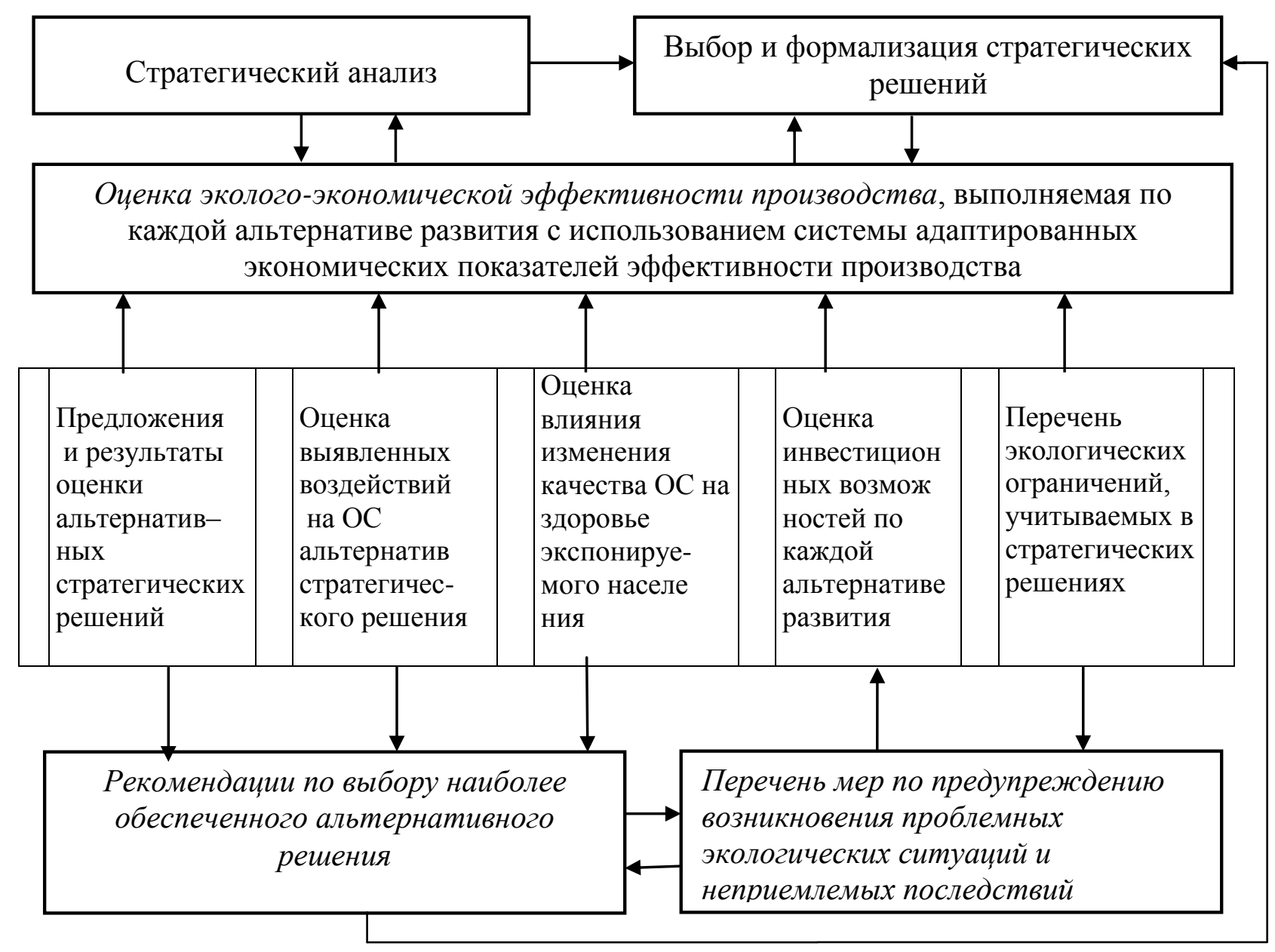

Рис. 12 . Влияние эколого-экономической эффективности на выбор стратегической альтернативы развития [47]

Как следует из схемы комплексная оценка эколого-экономической эффективности производства в полной мере охватывает социальноэкономические и экологические аспекты деятельности предприятия и, связанные с ними результаты и последствия, поэтому руководство компании может принимать стратегические решения по развитию предприятия на ее основе. На этапе выбора стратегии вырабатываются рекомендации по оценке правильности выбранного варианта и целей стратегического решения.

Современная концепция устойчивого развития выстраивает подход на убеждении, в соответствии с которым, природа экономического роста изначально содержит стремление к экологическому равновесию и не допускает исключения экологического фактора из хозяйственной деятельности субъектов рынка (даже в краткосрочном периоде). Поэтому, 
поддержка условий устойчивого развития обязывает уходить от действующей системы приоритетов хозяйственного роста предприятия, основанной на затратном подходе, что в свою очередь требует реформирования механизма реализации стратегии развития и связанного с ним организационного механизма (рис. 13, [47]). Последний, в итоге после уточнения принципов и процедур исполнения и проверки на адекватность и непротиворечивость действующему законодательству, может иметь следующий вид, представленный на рис. 13.

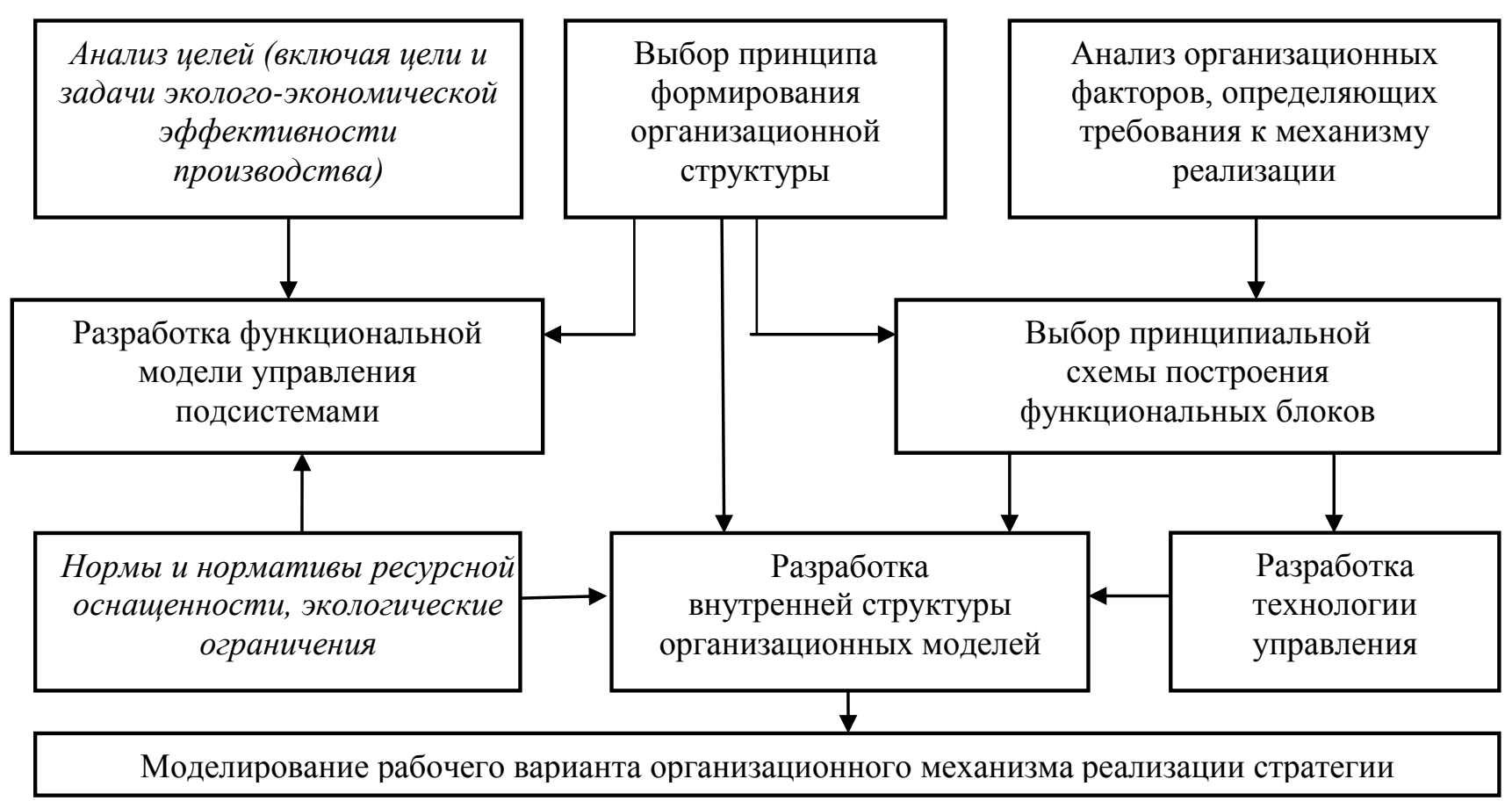

Рис. 13. Принципиальная схема организационного механизма реализации стратегии

Организационный механизм, в рассматриваемой системе принятия стратегических решений, требует трансформации по выделенным модулям: блок «нормы и нормативы ресурсной оснащзенности, экологические ограничения〉 и блок анализа.

Организационные преобразования механизма реализации стратегии сопровождаются рядом проблем, в том числе связанных с возможностью «встраивания» в него отдельных элементов, не противоречащих технологии организации и, кроме того, их введение важно для предприятий, имеющих 
основой хозяйственной деятельностью, использование воспроизводимых и невоспроизводимых природных ресурсов.

Согласно рис. 13 в блок «Моделирование рабочего варианта организационного механизма реализации стратегии» для повышения результативности принимаемых решений вводится процедура выбора типа инвестиционной политики предприятия (см. рис. 11) и дополняется системой, устанавливающей требования к формату представления и рейтингу инвестиционных проектов и программ (см. раздел 3.1 ).

Введение процедуры выбора типа инвестиционной политики, соответствующей сценарию хозяйственного развития предприятия, позволяет осуществлять дифференцированный подход к объектам различного масштаба воздействия на ОС через учет результатов планируемой к реализации деятельности. Система экономического стимулирования расширяется мерами, ориентирующими структурные подразделения предприятия, на снижение затрат по платежам за природопользование и загрязнение ОС, направленными на выявление дополнительных средств, как правило, за счет экономии сырья, материалов, электроэнергии, топлива и других природных ресурсов. В совокупности рассмотренные меры способствуют организации механизма реализации той стратегии развития, которая обеспечивает экологически приемлемый вариант экономического роста предприятия и ограничивает «технологическое» направление деятельности компаний.

\section{Вопросы и задания для самоконтроля}

1. Раскрыть содержание принципа «наилучшая из доступных технологий».

2. Раскрыть содержание понятия эколого-экономическая эффективность.

3. Дать характеристику модели оценки эколого-экономической эффективности от использования наилучших из доступных технологий.

4. Описать преимущества производств, реализующих проекты внедрения НДТ.

5. Определить на каких показателях состояния эколого-экономической безопасности отразятся результаты внедрения НДТ.

\section{Рекомендуемая литература}

1. Выварец А. Д. Экономика предприятия:учебник / А. Д. Выварец. ЮНИТИ-ДАНА, 2007. $543 \mathrm{c}$. 
2. Экономическая безопасность России: уроки кризиса и перспективы роста. / А. И. Татаркин, М. В. Федорова, И. С. Белик [и др.]; под редакцией А. И.Татаркина. Изд-во: Экономика, 2012. $1130 \mathrm{c}$.

\section{4. Бюджетный эффект от реализации проектов направленных на снижение риска здоровью населения от изменения качества ОС}

Важнейшими общепринятыми критериями общественного прогресса являются состояние здоровья и продолжительность жизни населения. В этой связи проблема ухудшения качества ОС, ее влияние на уровень заболеваемости и смертности населения актуальна для отдельных индивидуумов и их групп, а также для различных уровней управления национальным хозяйством. Безусловно, оценка степени риска своему здоровью из-за снижения качества окружающей природной среды является естественной поведенческой реакцией человека, основанной, в первую очередь, на выявлении ситуации, связанной с возможными отрицательными последствиями, поэтому можно утверждать, что на ней базируется вся система информационной связи человека с окружающим миром. Вероятно поэтому такие понятия, как «опасность», «угроза», связаны прежде всего с информацией о риске здоровью. Из чего можно заключить следующее: если бы методы оценки риска здоровью населения были введены 8 практику государственного санитарного надзора, систему государственного управления и хозяйствования, они помогли решить задачу, связанную с количественной характеристикой воздействия неблагоприятных условий среды на здоровье населения и с их экономической оценкой. Нельзя не отметить, что ряд основополагающих законов страны (Конституция РФ, Закон об охране ОС в РФ, Закон о санитарном и эпидемиологическом благополучии населения в Российской Федерации и др.) предусматривает ответственность государства, предприятий, организаций и отдельных граждан за ущерб, причиняемый здоровью населения загрязнением ОС. Однако реализовать в действительности правовую защиту населения невозможно из-за отсутствия достаточно веского 
методического аппарата установления причинно-следственных связей «среда здоровье» [44].

По существу оценка риска до настоящего времени представляет вид экспертных работ, направленных на определение числа людей, способных проявить негативные реакции на воздействие конкретного неблагоприятного фактора, действующего с определенной силой и в заданный промежуток времени. На взгляд автора, для того, чтобы система оценки риска здоровью обрела правовой статус, стала обязательной, аргументированной по сути, устанавливала причинно-следственные связи, необходимо еe «вероятностнорасчетный» характер базировать на опробованных и всеми принимаемыми методиках и моделях и основываться на достаточно полной информации о количественных и качественных характеристиках воздействующих факторов, о заболеваемости и здоровье населения. С этой целью необходимо создавать базу гигиенических нормативов, систему функционирования социальногигиенического мониторинга, который учитывал бы комплексное воздействие различных факторов на здоровье человека и пути поступления экологических токсикантов в организм.

\section{Справка}

В настоящее время ведущим принципом отечественной гигиены и системы медико-экологического регламентирования является установление безопасных уровней воздействия загрязнителей ОС. Основой данного положения служит концепщия «пороговости» вредного действия [33], постулирующая, что для каждого агента (фактора), вызывающего те или иные неблагоприятные эффекты в организме, существуют и могут быть найдены дозы (концентрации), при которых изменения функций организма будут минимальнылми (пороговыми). Несмотря на простоту и распространенность данного подхода в практике управления в последнее время стала активно внедряться концепция, основанная на положениях риск - анализа, согласно которой индикатором риска снижения качества ОС служит состояние здоровья человека, выраженное с помощью специальных показателей риска.

Методология медико-экологических исследований концепции риск анализа основана в значительной степени на предположении о том, что риск, создаваемый факторами окружающей человека среды, пропоричонален его дозе (или концеентрации). При этом предполагается и допускается, что чем больше продолжительность контакта фактора с биологической тканью, тем больше вероятность неблагоприятных эффектов. На основании этого условия 
делается вывод о том, что для определения риска нужно знать осредненную воздействующую концентрацию (или дозу) и время, в течение которого эта концентрация (доза) действовала на организм [33].

В контексте концепции факторы риска рассматриваются как условия ОС, существенно повышающие риск возникновения заболеваний населения. Среди геоэкологических факторов риска здоровью населения обычно выделяют уровень атмосферного загрязнения, качество питьевой воды, почвы.

Важнейшим элементом природной среды, несущим основную техногенную нагрузку, по данным Соросовского образовательного журнала [45], считается загрязнение воздуха (выделяется как ведущий параметр дифференциации территории по состоянию среды обитания). Утверждение иллюстрируется данными по замедлению физического и нервно-психического развития у детей в городах с металлургической промышленностью и высоким уровнем загрязнения воздуха (заболеваемость детского населения чаще всего является основным параметром общественного здоровья) по сравнению с контрольными группами. Кроме того, доказывается, что воздействие атмосферных загрязнений сопровождается изменением функции внешнего дыхания, сердечно-сосудистой системы. По данным Б. А. Ревича, в городах с развитой нефтехимической промышленностью и вблизи автомагистралей у детей жизненная емкость легких, резервные объемы вдоха и выдоха снижены на 10-30 \%, а у детей, проживающих рядом с предприятиями стройиндустрии с большим пылевым выбросом, - на 70 \% [33]. Согласно тем же данным совместное действие пьли и некоторых загрязнителей в современных городах имеет высокотоксичный эффект, в частности: канцерогенный эффект наблюдается при совместном действии бензола, никеля, сажи, бензапирена и формальдегида; нарушение репродуктивной функции женщин и врожденные патологии - при соединении углеводородов с тяжельми металлами, такими как свинец, ртуть, медь.

Приводимая характеристика влияния техногенных нагрузок на ОС и далее на здоровье человека убеждает, что необходимость реализовать правовой 
и экономический механизм защиты здоровья населения от экологически обусловленных заболеваний давно назрела.

В соответствии с современной теорией риск - менеджмента риск обычно интерпретируется как вероятностная мера возникновения техногенных или природных явлений, сопровождающихся формированием вредных факторов и нанесением социального, экономического, экологического, а в ряде случаев и эстетического ущербов [39].

Под экологическим риском понимается вероятность наступления события, имеющего неблагоприятные последствия для природной среды и вызванного негативным воздействием хозяйственной и иной деятельности, чрезвычайными ситуациями природного и техногенного характера. Проявляется экологический риск в вероятностных величинах или математическим ожиданием ущерба [39].

Оцуенка экологического риска представляет исследование, в котором факты и научный прогноз используются для определения потенциально вредного воздействия на ОС различных загрязняющих веществ и других агентов. При оценке влияния негативного изменения качества атмосферного воздуха от загрязнения выбросами опасность ухудшения здоровья количественно оценивается на основе теоретических расчетов, а также статистических данных о результатах медико-экологических обследований. Теоретические расчеты и оценки риска проводятся по схеме «доза - эффект». Под дозой понимается количественная мера вредного воздействия на организм, под эффектом - патологические и иные последствия этого воздействия. Эта схема является приемлемой для всех видов организмов живой природы: человека, животных, птиц, обитателей водной среды, растений и микроорганизмов. Однако наибольшее практическое применение она находит в практике оценки ухудшения здоровья человека [39].

Определение уровня (меры) воздействия является стадией процесса оценки риска и представляет собой сложную процедуру, которая включает диагностику источников и характера выбросов, путей распределения загрязнителей и воздействия химического вещества для установления 
концентраций (доз), при которых может иметь место воздействие на человека. Используемый в международной практике алгоритм включает следующие этапы [39]:

1. Идентификация опасности (вредности): выполняются действия, связанные с определением факторов, уровней и путей воздействия, осуществляется проверка правдоподобия и подтверждения ассоциации между фактором и заболеванием. На данном этапе формулируются конкретные проблемы и приоритетные задачи, а также намечаются пути их решения. Как отмечалось, первоначально производится инвентаризация источников, приводится характеристика объемов выбросов (эмиссия), параметров, необходимых для расчета максимально разовых и среднегодовых концентраций. Определяются потенциально опасные факторы (абсолютно все присутствующие в ОС вещества), формируется перечень приоритетных (наиболее опасных) факторов.

2. Оиченка экспозиц̧ии. Включает характеристику источников загрязнения, маршрутов движения загрязняющих веществ от источника к человеку, пути и точки воздействия, уровни экспозиции и др.

Целью данного этапа является определение доз и экспозиций, воздействовавших в прошлом, в настоящем или тех, которые возможно будут оказывать действие в будущем, а также установление уровней экспозиции для популяции в целом и eе отдельных субпопуляций, включая сверхчувствительные группы.

В рамках работ, выполняемых на этапе, очерчиваются границы территории, выделяются группы населения, включая чувствительные подгруппы, исследуется маршрут воздействия по схеме «источник воспринимающая среда - транспортирующие и трансформирующие среды воздействующая среда - точка контакта - путь поступления - экспонируемая группа населения». Определяются воздействующие дозы и концентрации с учетом выбранного маршрута экспозиции (воздействующих сред и путей 
поступления). По итогам проведенных работ представляются следующие результаты:

- моделирование концентраций (модели рассеивания);

- моделирование межсредовых переходов (концентрации во всех воздействующих средах);

- данные по максимально разовым, среднегодовым концентрациям, статистическому распределению;

- данные прямого мониторинга (индивидуальный отбор проб);

- факторы экспозиции (суточная активность, потребление воздуха, воды, продуктов и др.);

- расчет воздействующих доз для населения в целом и отдельных чувствительных групп;

- расчет суммарных доз для всех маршрутов экспозиции, путей поступления, воздействующих сред; выполняется характеристика суммарной нагрузки.

Важнейшей частью работ этого этапа является определение концеентрацчии каждого из ЗВ в атмосферном воздухе городов. Как показывает практика, установление концентрации (дозы) связано с проблемой недостаточности или отсутствия информации. Чаще всего в расчетах используются данные мониторинга, отражающие суммарное воздействие от всех источников загрязнения, при этом замеры концентрации веществ, выбрасываемых в атмосферу, нередко осуществляются по ограниченному кругу загрязнителей и источников, что приводит к неполноте в исследованиях, требующих идентификации выбросов от конкретного объекта. Кроме того, численность экологических постов крайне ограничена и в большинстве случаев замеров концентрации не производится. По этой причине для расчета приземной концентрации загрязняющих веществ применяется моделирование, которое в задаче оценки риска дает возможность учесть заданность участка местности, неизменность состояния ОС, механизм распространения токсинов и их воздействия на человека. На практике чаще всего используют 
дисперсионные модели, позволяющие рассчитывать концентрацию в точке воздействия [44].

3. Установление зависимости «доза-ответ»- выявление связи между состоянием здоровья (например, доли лиц, у которых развилось определенное заболевание) и уровнями экспозиции. Данный анализ обычно проводится раздельно для канцерогенов и для веществ, не обладающих канцерогенным действием. В ходе анализа выявляются:

- ПДК по санитарно-токсическому признаку вредности;

- референтные концентрации (уровни минимального риска);

- факторы канцерогенного потенциала;

- параметры зависимости «доза - ответ» для неканцерогенов (риск нарушения здоровья на единицу дозы/концентрации);

- поражаемые органы и системы, тяжесть изменений при разных уровнях воздействия;

- установление этиологической связи между экспозицией и фактическими показателями состояния здоровья населения, выявление вклада изучаемого фактора в риск развития нарушений состояния здоровья.

Методология медико-экологических исследований [33,44] основана на предположении о том, что риск, создаваемый факторами окружающей человека среды, пропорционален их дозе (или концентрации). Осредненная воздействующая конщентращчия (доза), действующая на организм в течение определенного времени, определяется по формуле

$$
L A D I=\frac{C \cdot W \cdot F \cdot T_{\mathcal{H}}}{M \cdot T_{o}},
$$

где $L A D I-$ средняя пожизненная доза, мг/(кг день);

$C$ - средняя концентрация загрязняющего вещества в контактирующей с

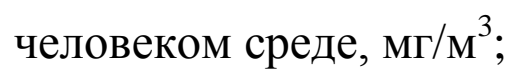

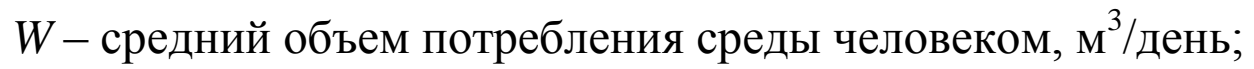

$F$ - время контакта со средой, дней/год;

$T_{ж}-$ средняя продолжительность жизни, лет; 
$M$ - вес тела человека, кг;

$T_{o}$ - период времени действия дозы, дней.

4. Характеристика риска. На данном этапе выполняется анализ всех полученных данных, расчетов рисков для популяции и ее отдельных подгрупп, сравнение рисков с допустимыми (приемлемыми) уровнями, сравнительная оценка и ранжирование различных рисков по степени их статистической, медико-биологической и социальной значимости. Цель этапа - установление медицинских приоритетов и тех рисков, которые должны быть предотвращены или снижены до приемлемого для данного общества уровня. Для ее достижения выполняются следующие процедуры:

- определения значений рисков для отдельных факторов при разных путях воздействия из определенных сред;

- расчета суммарных рисков для маршрутов воздействия, путей поступления, суммарных рисков для веществ с одинаковым типом вредного действия;

- расчета интегрированных индексов опасности для факторов с разным типом вредного действия, например, канцерогенов и неканцерогенов;

- анализа распределения рисков в популяции, в особо чувствительных подгруппах, выявление сверхэкспонируемых индивидуумов;

- сравнения многолетней динамики рисков на данной территории;

- ранжирования факторов, источников загрязнения, территорий;

- сравнительной характеристики рисков влияния на здоровье, экологических рисков, влияния факторов на условия и качество жизни населения;

- определения приоритетных проблем для данной территории.

Ключевой в этой последовательности процедур является стадия установления количественных характеристик воздействия на здоровье человека, т. е. определения потенциального и индивидуального риска, пожизненного риска (вероятность заболеть раком и умереть - ILCR и 
вероятность получить нераковое заболевание - $H I)$ и популяционного риска $(P R)$.

Потенцииальный риск определяется в соответствии с уровнем загрязнения атмосферного воздуха и интенсивностью воздействия ряда других факторов (шум, загрязнение питьевой воды и пр.) и позволяет оценить вероятность неблагоприятного эффекта, связанного с этими загрязнениями. Другими словами, потенциальный риск определяет максимальный размер группы риска (в процентах или долях единицы), т. е. количество населения, у которого потенциально могут проявиться неблагоприятные эффекты, связанные с данным экологическим фактором.

Определение индивидуального риска (IR) представляет собой особую форму медико-экологической экспертизы, целью которой является диагностирование случаев экологически обусловленных заболеваний. К сожалению, в настоящее время еще не разработана правовая основа государственной системы диагностирования этих заболеваний, как нет и утвержденного определения «экологически обусловленное заболевание». Пока основные функции по установлению признаков заболеваний экологической этиологии возлагаются на лечебно-профилактические учреждения, относящиеся к административным образованиям. Выявление признаков заболеваний производится в период обращения населения за медицинской помощью и при проведении медицинских осмотров. При этом выделяются следующие этапы диагностики. Для оценки индивидуального риска важным является определение внутренней дозы химического вещества, зависящей от конкретных особенностей контакта человека с ОС. Наиболее точным методом расчета внутренней дозы является ее биоиндикация, т. е. лабораторное количественное определение экологических загрязнителей или их метаболитов в тканях и органах человека. Сопоставление лабораторных результатов с существующими стандартами позволяет определить реальную внутреннюю дозу экологической нагрузки. Однако для большинства наиболее распространенных химических загрязнителей биоиндикация или невозможна, 
или затруднена. Поэтому другим способом определения внутренней дозы является расчет. Один из вариантов такого расчета - использование информации о концентрациях химических веществ в различных зонах пребывания человека и среднего времени его нахождения в этих зонах. Так, например, проведя анкетирование, можно определить среднее время пребывания человека внутри жилища, в жилой зоне, загородной зоне, транспорте, в рабочей зоне. Зная конщуентращию вещзества, объем вдыхаемого воздуха, время нахождения в различных зонах, эксперт может рассчитать получаемую за год внутреннюю дозу, которая в данном случае называется аэрогенной нагрузкой. Суммировав аэрогенные нагрузки по отдельным веществам, можно рассчитать суммарную индивидуальную аэрогенную нагрузку. Различные вещества обладают неодинаковой токсичностью, в связи с чем для оценки риска целесообразно использовать не просто аэрогенную нагрузку в миллиграммах вещества, а величину потенциального риска. Количественная экономическая оценка воздействия загрязнения на здоровье человека выражается в категориях экономических потерь (рис.14), [27], представляющих собой индивидуальные или общественные расходы, которые можно избежать при сокращении экологического ущерба и воздействии на здоровье населения. Существующие подходы, применяемые к оценке влияния условий ОС на здоровье населения, представлены на рис. 14.

Для оценки индивидуальных потерь чаще всего применяются методики, основанные на затратном подходе. В основе таких методик лежит оценка индивидуальных дополнительных затрат человека, связанных с вредным воздействием ОС на условия его жизнедеятельности.

Оценка общественных потерь производится с помощью доходного подхода, который основан на определении величины потенциального дохода, недополученного обществом в результате потери жизни полностью или частично отдельным человеком. 


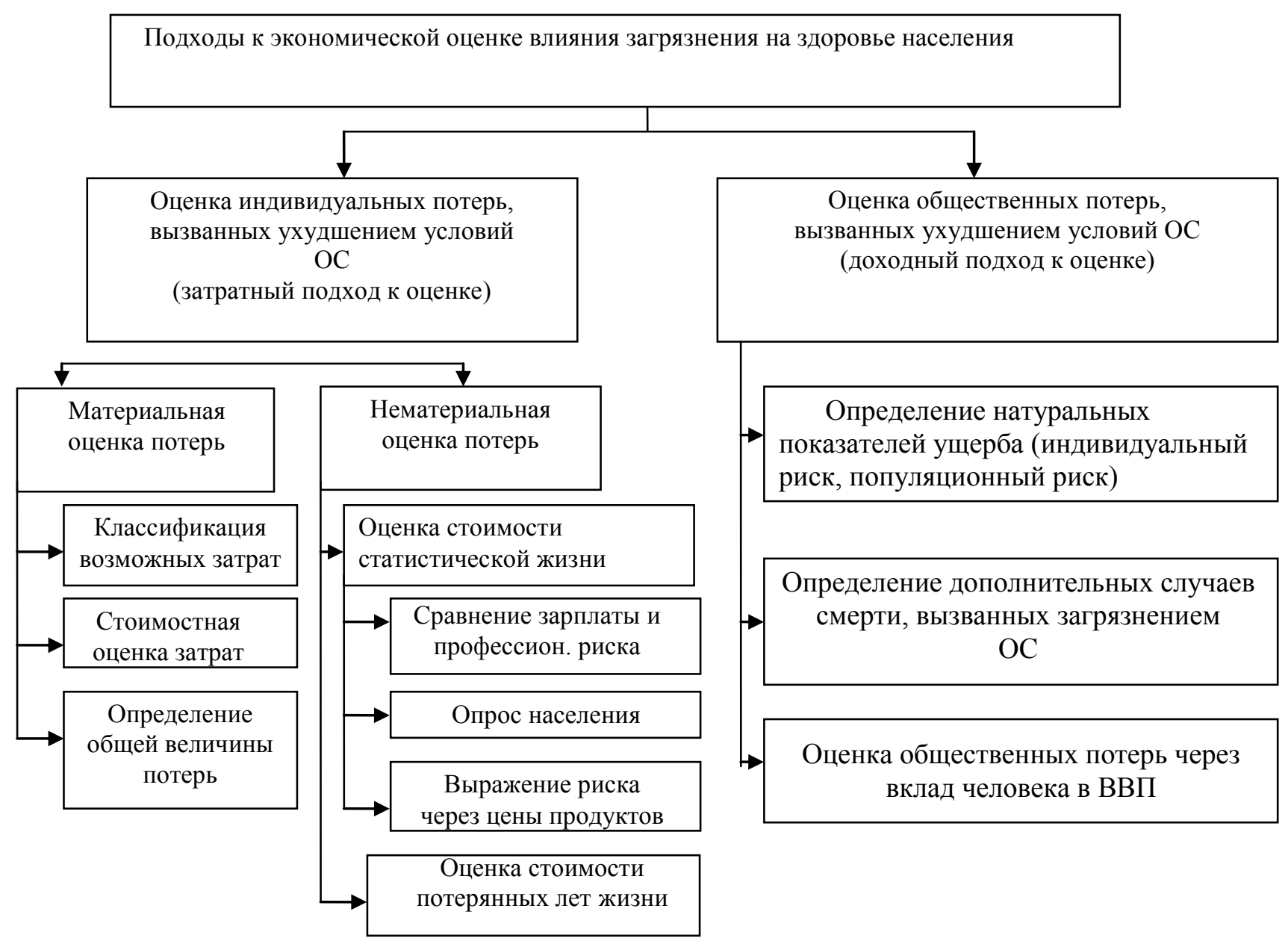

Рис. 14. Классификация методических подходов, используемых для оценки воздействия на здоровье населения

Затратный подход предполагает оценку стоимости всех дополнительных затрат, возникающих у человека и связанных с потерей здоровья под воздействием условий ОС. Перечень таких затрат достаточно обширный и может варьироваться в разных методиках. Чаще всего выявляются и количественно оцениваются прямые и косвенные расходы, связанные с заболеванием. К ним обычно относятся:

- расходы на медикаменты превентивного характера;

- расходы на медикаменты для лечения острых и хронических заболеваний;

- стоимость экстренного лечения (скорая помощь, интенсивная терапия);

- стоимость лечения в стационаре (уход за больными и амбулаторные услуги); 
- стоимость лечения на дому, стоимость реабилитации, потеря трудоспособности, перераспределение дохода;

- нематериальные затраты (страдания, связанные с заболеванием или смертью).

Состав и характеристика затрат, формирующих эти расходы, приводятся в соответствии с перечнем по источнику [33].

Расходы на медикаменты (меры превентивного характера и лечение)

Получение сумм денежных значений для первых двух отмеченных категорий затрат требует наличия данных по использованию и стоимости медикаментов для предупреждения заболевания и его лечения (розничная цена лекарственных средств). В случае с государственным сектором (или страховыми компаниями), если цена на медикаменты дотируется, необходимо получить реальную цену. Для проведения расчетов общей стоимости используют данные по стоимости единицы случая лечения или принятия мер превентивного характера для всех людей, у которых выявлены эти симптомы (например, среднегодовая стоимость лекарств на категорию заболевания).

Стоимость экстренного медицинского вмешательства и пребывания в cтациионаре

Затраты на экстренное вмешательство включают транспортирование машиной скорой помощи, стоимость персонала, а также возможно расходы на интенсивную терапию в больнице. Стоимость стационарного лечения (интенсивная терапия, уход за больными и амбулаторное лечение) должны быть предоставлены за день пребывания в стационаре, предпочтительно по категориям в зависимости от интенсивности лечения. По крайней мере данные затраты должны покрывать среднюю оплату (зарплата + социальные выплаты) труда в больнице, включая технический персонал (уборка, приготовление еды, пр.), медсестер, врачей и докторов. Подсчитывается и стоимость лекарственных средств в стационаре в соответствии с оптовыми ценами.

В случае необходимости расчета реальной общей себестоимости лечения в больнице требуется включать все капитальные затраты и текущие расходы 
больницы и ее служб, основанные на бухгалтерских данных, т. е. техническое обслуживание, оплату за электричество, воду и др.

\section{Стоимость лечения на дому}

Лечение на дому имеет стоимость в случае, когда его предоставляют общественные фонды или услуги здравоохранения, и оплата производится в частном порядке. В состав затрат на амбулаторное лечение включают составляющие, описанные в предыдущем разделе, а именно, общие расходы на зарплату по обработке вызова. Лечение на дому в основном проводится родственниками или друзьями пациента. В ряде случае это может занимать достаточно длительное время. Однако присвоение значения стоимости ухода, оказываемого ближайшими родственниками, затруднительно. Если эта категория включается в инвентаризацию, то можно использовать значение стоимости упущенной выгоды, т. е. заработок, потерянный человеком, в результате ухода за больным. Лечение на дому может вызвать необходимость проведения ремонта и покупки специальных приспособлений для поддержания жизнедеятельности больного. Стоимость этих компонентов также должна быть включена в полную инвентаризацию.

\section{Стоимость реабилитацчии}

Расчет стоимости реабилитации аналогичен составлению инвентаризации лечения в больнице. В этом случае необходимы данные по количеству и продолжительности реабилитационного лечения, наряду с соответствующими расчетами общей стоимости дня (или часа) пребывания в больнице, лечебном учреждении или лечения на дому.

\section{Потерянная работоспособность}

Заболевания приводят к потере работоспособности (потерянной производительности), что означает потерю личного дохода и производственные потери для работодателей. Традиционный подход учета таких потерь основан на усреднении вклада работника, выраженного как ВВП на душу населения. Это может быть определено из валовой цифры, включая средний заработок (например, личное потребление) и вклад в ВВП в виде рабочей силы, или как 
чистый ВВП личного потребления. Если для расчета потери личного дохода используется заработная плата, то необходимо рассчитать средневзвешенные значения по отношению к численности работающего населения по различным категориям заработной платы.

Для оценки потерянного заработка и производительности необходимо знать среднюю продолжительность периода нетрудоспособности по основным категориям заболеваний, а также количество потерянных работоспособных лет по причине преждевременной смерти. Производственные потери и потери дохода рассчитываются для всего населения достаточно просто как средний годовой ВВП на душу населения, без разделения людей на категории трудовых ресурсов (в основном дети, безработные, пенсионеры и нетрудоспособные). Годовой ВВП также может быть усреднен по отношению к рабочему дню.

\section{Перераспределение дохода}

Люди, теряющие работоспособность, или член семьи, оказывающий поддержку больному, вероятнее всего получают перераспределение доходов со стороны государства, например, в форме пенсии по утере трудоспособности, обеспечивающей средства проживания. Это дополнительные расходы, вызванные заболеванием, причиной которого может быть плохое качество вод или атмосферного воздуха.

Перераспределение дохода может быть рассчитано путем усреднения пенсий по отношению к общему числу пенсионеров, получающих пенсии.

Будущие прогнозы материальных статей расходов

С целью получения будущих изменений приведенных выше статей расходов, например в системе «затраты - выгоды», некоторых экологических инициатив следует текущие значения скорректировать с учетом коэффициента инфляции, так как со временем можно ожидать изменения стоимости лекарственных препаратов и расходов на лечение. Также могут произойти изменения в производственных возможностях людей в случае прироста ВВП на душу населения. Очевидной проблемой в этом случае будет выбор правильного индекса цен, особенно при высокой инфляции. Обычно с этой целью 
используют низкие процентные ставки, способствующие пролонгированным потокам прибыли.

Перечисленные виды затрат также предполагают потерю некоторого материального благополучия. В дополнение к этим затратам меняется благополучие человека от общуего качества жизни, т. е. нематериальная составляюшуая ущчерба.

Нематериальные потери предлагается оценивать [27] с помощью:

- оценки стоимости статистической жизни;

- стоимости потерянных лет жизни.

Стоимость статистической жизни традиционно оценивается эмпирическими методами:

1. Сравнение заработной платы и профессиональных рисков традиционный способ (риск оценивается через прирост заработной платы по профессиям, связанным с различным уровнем риска). Таким образом, можно экономически оценить прирост риска посредством увеличения заработной платы.

2. Опрос населения с целью выявления готовности платить за снижение риска. Наиболее распространенный способ заключается в установлении суммы, которую готов платить человек за снижение среднего риска на один процент сокращения риска. Деление средней стоимости риска на процент его сокращуения приводит к получению статистической потерянной жизни.

Основной недостаток данного подхода - предположение о линейной зависимости между изменением риска и желанием платить, что недостаточно корректно. Кроме того, сокращение риска может считаться незначительным в сравнении с другими проблемами, с которыми человек сталкивается в повседневной жизни.

3. Обособление характеристик для снижения риска в ценах продуктов, с которыми связаны риски. Метод основан на готовности людей внести вклад (готовность платить) за возможность избежать рисков. В различных 
исследованиях, проводимых в странах Европы, используется величина стоимости статистической жизни в размере 3,1 млн евро [44].

Стоимость потерянных лет жизни - альтернативный подход оценки воздействий заболеваний, позволяющий получить значение стоимости потерянных лет жизни. Основой для расчета является стоимость статистической жизни [44].

Соотношение между стоимостью статистической жизни и потерянных лет жизни в расчетах острой смертности описывается формулой

$$
\operatorname{VOSL}_{a}=\operatorname{VOLY}_{r} \cdot \sum_{i=1+a}^{T} P_{i}(1+r)^{i-a-1}
$$

где $V O L Y_{r}-$ стоимость потерянных лет жизни;

$V O S L_{a}-$ стоимость статистической жизни;

$\mathrm{P}_{i}-$ условная вероятность доживания до года $i$, дожив до года $a$;

$a-$ возраст лиц, для которых рассчитывается стоимость статистической жизни;

$T$ - верхняя возрастная граница;

$r$ - коэффициент дисконтирования.

Ha практике получила эмпирическое подтверждение другая аналитическая зависимость, связанная с оценкой хронических эффектов $\left(V_{\text {OL }}^{r} Y_{\text {chon }}\right)$, в которой условная вероятность доживания до года $i$, заменена отношением числа лет потерянной жизни к общему числу потерянных населением лет:

$$
V O L Y_{c h r o n}^{r}=\sum_{i=1}^{i=T} \frac{Y O L L_{i}}{Y O L L_{t o t}} \cdot \frac{V O L Y^{r}}{(1+r)^{i-1}}
$$

где $Y O L L_{i}$ - число лет потерянной жизни как результат роста опасности в год $i$ в каждый будущий год;

$Y O L L_{t o t}$ - общее число потерянных населением лет.

Основным недостатком такого подхода является его трудоемкость и сложность расчетов.

Основные условия реализации этого подхода состоят, во-первых, в классификации диагностируемых симптомов, связанных с определенными 
загрязняющими веществами, а во-вторых, с получением статистических данных по числу и продолжительности случаев заболеваний и количества смертей за год.

Общественные потери, как правило, определяются на основе доходного подхода, т. е. дохода, который недополучен в результате потерянной жизни полностью или частично.

Для расчета экономических показателей первоначально определяются натуральные показатели ущерба - количество дополнительных случаев смерти или количество потерянных лет жизни. Такой расчет основывается на определении индивидуального и популяционного риска.

Таким образом, основной задачей становится определение натуральных показателей ущерба, т. е. количества дополнительных случаев смерти.

Наиболее приемлемой и апробированной представляется международная методика определения индивидуального и популяционного риска. Для определения риска по каждому канцерогенному загрязнителю устанавливается фактор потенциала $(S F)$, который является основой пересчета для среднесуточного поступления канцерогенного загрязнителя (C) в uндивидуальный пожизненный риск (IR) и пожизненный риск смерти (IRCR):

$$
\begin{gathered}
I R=C \cdot S F \\
I R C R=L A D I \cdot S F .
\end{gathered}
$$

Популяционный риск определяет число случаев смерти или заболеваний, которые могут возникнуть во всей популяции или в отдельных ее группах в результате воздействия изучаемого загрязнения.

Расчет общественных потерь в результате преждевременной смерти основан на усреднении вклада работника, выраженного в ВВП на душу населения с учетом временного фактора. Потери общества на одного умершего с учетом количества лет жизни можно определить по формуле

$$
\sum_{i=1}^{n} P V=\frac{F V}{(1+r)^{n}}
$$

где $P V$ - текущие потери (стоимость в настоящий момент времени), д. е.; 
$F V$ - будущие потери (стоимость на будущих периодах расчета), д. е.; $r$ - процентная ставка (принимается, как правило, на уровне депозитной ставки), ед.;

$n$ - количество потерянных лет жизни.

Наиболее удобным методом определения экономических потерь с авторской точки зрения является именно доходный подход, т. к. его отличает простота применения и наглядность. Кроме того, он позволяет осуществить пересчет дополнительных случаев смерти к фоновой смертности в годы сокращения продолжительности жизни населения, что исходя из требования информативности показателей может быть использовано в разработке сводного индикатора, определяющего уровень роста заболеваемости и смертности от экологически обусловленных заболеваний.

Возвращаясь к проблеме расчета концентрации (дозы) загрязняющего вещества в приземном слое, в исследовании предлагается величину дозы рассчитывать через учет среднесуточной массы выбросов. Поскольку ныне утвержденная Председателем Государственного комитета РФ по охране ОС 30.11.1999 г. «Методика определения предотвращенного ущерба», как и ранее действовавшая временная методика 1986 г., не позволяют определить величины концентрации в приземном слое (среднесуточное пос-тупление 3В), контактирующие с биологической тканью (организм человека).

Вариантом расчета величины среднесуточного поступления ЗВ на единицу массы человека может служить методика [27].

В соответствии с методикой, если в зоне активного загрязнения не производится замеров концентрации загрязняющих веществ, то приблизительная величина среднесуточного поступления, рассчитанная на единицу веса тела человека, может быть найдена по формуле

$$
C=\frac{\sum m_{i} \cdot V}{h \cdot S \cdot T \cdot M} \cdot f
$$

где $m_{i}$ - фактическая масса загрязняющего вещества $i$-го вида, выбрасываемая за год, т/год; 
$h$ - усредненное значение высоты приземного слоя (в расчетах принимается равной 2 м), м;

$f$ - поправка (безразмерная величина), учитывающая характер

рассеивания загрязняющего вещества в атмосфере;

$S$ - площадь зоны активного загрязнения (ЗАЗ), м²;

$T$ - количество дней в году;

$V$ - объем воздуха, проходящего через легкие человека в течение суток;

$M$ - масса тела человека, кг.

Для определения величины $S$ организованных источников использованы следующие формулы:

$$
S=\pi \cdot\left(r_{\text {внеш }}-r_{\text {внутр }}\right)^{2},
$$

где $r_{\text {внеш }}-$ внешний радиус зоны активного загрязнения $\left(r_{\text {внеш }}=20 \cdot \varphi \cdot h^{\prime} ;\right.$

$\varphi$ - поправка на подъем факела выброса в атмосфере, т. е. $\varphi=1+\frac{\Delta T}{7^{0} C}$;

$\Delta T$ - среднегодовое значение разности температур в устье источника и в окружающей атмосфере, $\left.{ }^{0} \mathrm{C}\right)$;

$r_{\text {внутр }}-$ внутренний радиус зоны активного загрязнения;

$$
r_{\text {внутр }}=2 \cdot \varphi \cdot h^{\prime},
$$

где $h^{\prime}$ - высота источника (трубы), м.

Однако опыт использования методики показал, что применение выражения (23) возможно только для расчета средней концентрации локальных территорий, примыкающих к источнику загрязнения.

Рекомендовать ее к более широкому применению для крупных территориальных образований возможно лишь в случае использования показателя, характеризующего степень отклонения $\left(\kappa_{i}\right)$ приземной концентрации ЗВ $i$-го вида от установленного допустимого уровня: 


$$
1-\frac{C_{i}}{M_{i}-F_{i}} \geq \kappa
$$

где $M_{i}-$ пороговое значение концентрации конкретного 3В;

$C_{i}$ - текущее значение концентрации ЗВ $i$ - го вида в приземном слое;

$F_{i}$ - фоновое значение ЗВ $i$-го вида.

Коэффициент $\kappa_{i}$ может принимать значение $\geq 0$ или равное нулю. В этом случае воздействие приземных концентраций (кроме загрязнителей, являющихся канцерогенами) на организм человека дает малую вероятность заболевания в результате постоянного контакта с ЗВ и последующего перехода в состояние нетрудоспособности. При использовании показателя «степень отклонения» $\left(\kappa_{i}\right)$ риск поступления загрязнителя $i$-го вида в организм человека, устанавливаемый через фрактор потенц̧иал, должен определяться зависимостью, которая имеет форму, отличную от обычно наблюдаемой в исследованиях.

Данное обстоятельство инициировало поиск в области методического обеспечения системы экологических индикаторов и индексов сводными индексами «качества ОС», отражающими рост экологического риска от ухудшения качества окружающей природной среды и проявляющимися в снижении уровня здоровья населения. Вариантом индикатора, позволяющим учитывать ухудшение состояния здоровья населения от изменения качества ОС и одновременно транслировать эту информацию в систему принятия решений, может стать агрегатный «индекс здоровья населения» (табл. 36), [6]. Ценность его для диагностики ЭЭБ, выработки приоритетов развития очевидна, поскольку он позволяет увязать ухудшение качества ОС от увеличения техногенной нагрузки с повышением риска здоровью населения и ростом экологически зависимых заболеваний. Кроме того, формат предоставляемой информации по здоровью (агрегатный индекс) таков, что его можно рекомендовать к использованию в стратегической оценке положения региона. 
Социально-бюджетный аспект природоохранных проектов, обеспечивающий привлечение инвестиционных ресурсов

Теория экологического риска и прикладная ее часть - установление уровня приемлемого риска воздействия на здоровье людей - являются, несомненно, одним из основных инструментов концепции экологической безопасности. Как отмечалось, проблема обеспечения эколого-экономического развития на основе принципов безопасности тесно увязана с проблемой устойчивого развития. Поэтому выбор оптимального «сценария управления риском» при условии сохранения устойчивости развития, на взгляд автора, рекомендуется выполнять на основе подхода «затраты - эффективность». В этом случае «сценарий» (или система мер) управления, для которого прогнозируется наибольший эффект снижения риска на единицу предстоящих затрат, будет предпочтительным. В соответствии с теорией риска важнейшим элементом оперативного и долгосрочного управления риском является научное обоснование, установление и контроль за соблюдением нормируемых уровней загрязнения ОС (ПДК, ОБУВ).

Слабостью системы гигиенического нормирования ПДК, применяемой в настоящее время, является то, что для одного и того же загрязнителя в разных компонентах ОС эти гигиенические нормативы, как правило, обосновываются независимо друг от друга разными исследователями, а иногда на базе не полностью совпадающих критериев безвредности. В этом отношении методология оценки риска открывает новые возможности. Определение переносимой («референтной») дозы для системных токсикантов на этапе 
Характеристика сводного индикатора уровня здоровья населения от влияния экологического фактора

\begin{tabular}{|c|c|c|}
\hline $\begin{array}{c}\text { Наименование индикатора, } \\
\text { характеризующего уровень здоровья } \\
\text { населения }\end{array}$ & Формула расчета & Состав формулы \\
\hline 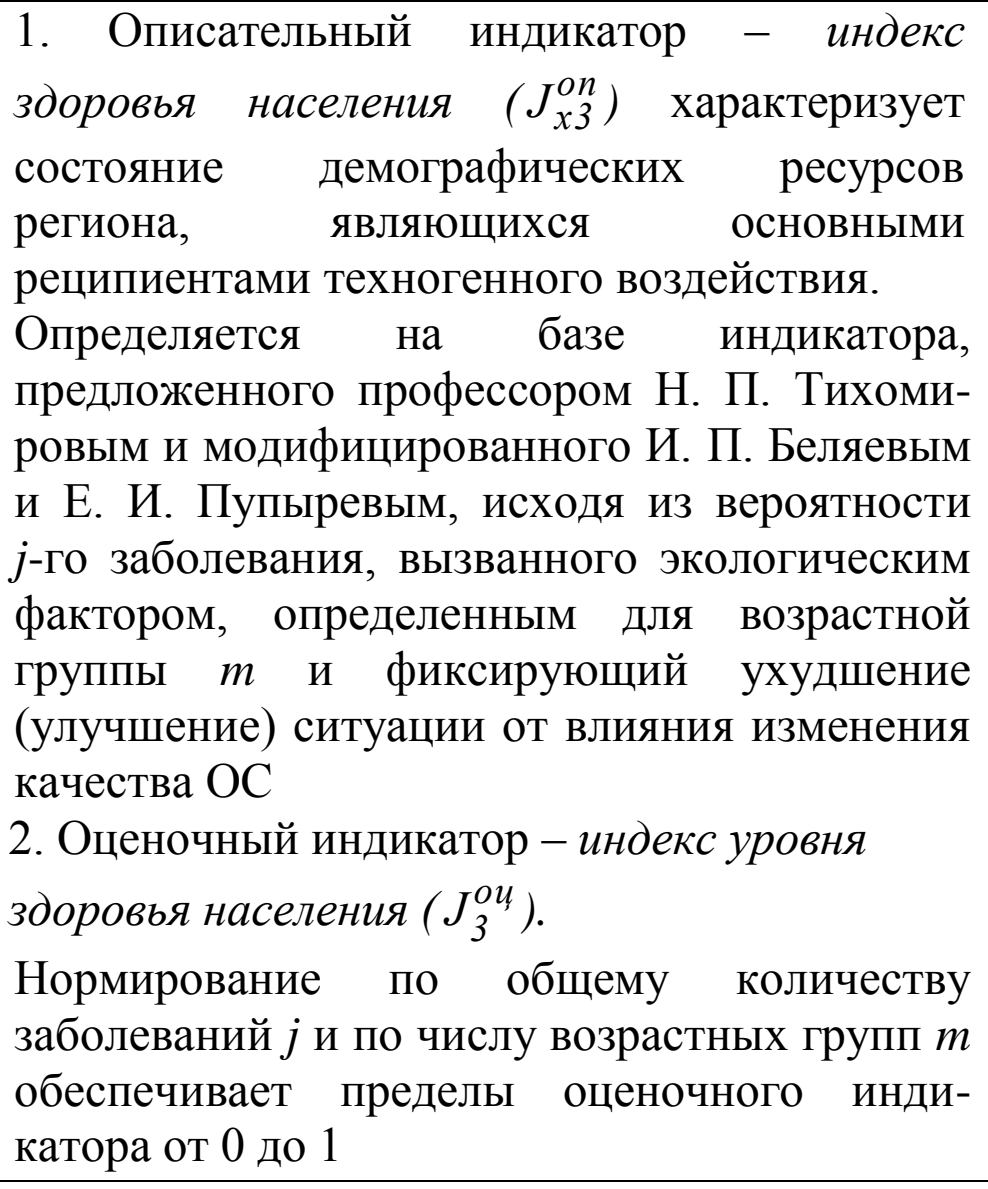 & $\begin{array}{c}G_{m j}=\frac{X_{m j}}{n_{m}} \\
H_{j m}=\frac{Д_{j m}}{Д_{m}}\end{array}$ & 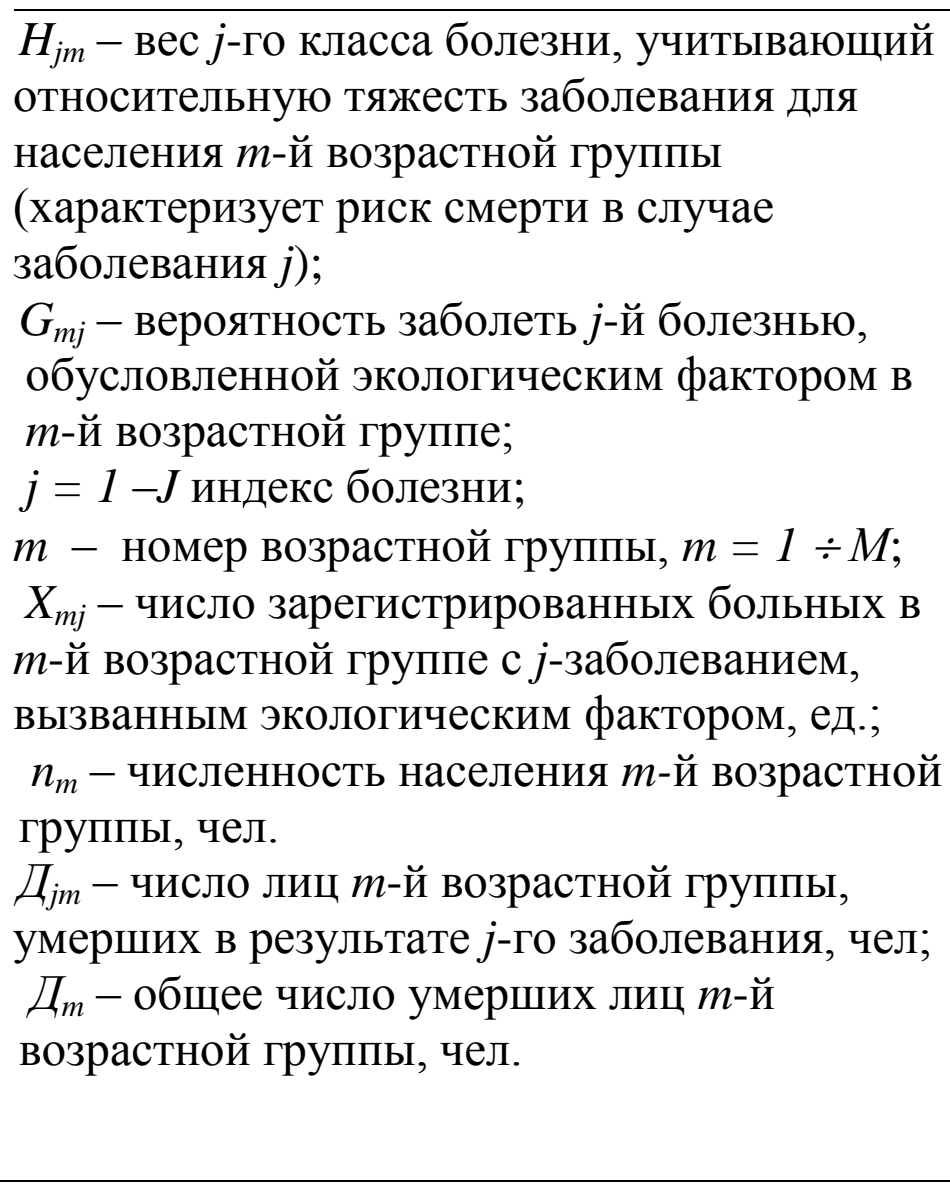 \\
\hline
\end{tabular}


оценки зависимости «экспозиция - ответ» дает возможность расчёта соответствующих ей переносимых концентраций в каждом компоненте среды при том или ином соотношении путей экспозиции.

Вероятно, с учетом рекомендаций ВОЗ в скором времени универсальным инструментом для определения адресных, целенаправленных и эффективных действий по обеспечению санитарно-эпидемиологического благополучия населения станет развитие методологии оценки риска влияния на здоровье населения неблагоприятных факторов среды обитания. Универсальность способа состоит в том, что он позволяет проводить многофакторную оценку риска с учетом воздействия социально-экономических, экологических, производственных, индивидуальных и иных факторов, а также многосредовую оценку с учетом факторов загрязнения атмосферного воздуха, питьевой воды, почвы и продуктов питания. Вопрос о его широком практическом применении сдерживается проблемой открытости информации об относительной неопределённости оценки риска, передаваемой пользователю, и представления ее как детерминированной величины, относительно которой не обсуждаются неопределённости, связанные первоначально с её научным обоснованием, но и механизмами охраны ОС и природопользования, сориентированными изначально на соблюдение ПДК (рис. 15). Однако из отмеченного не следует, что использование других способов, оценивающих влияние на здоровье населения ухудшения качества ПС, например, эколого-эпидемиологическое изучение (исследования ЭЭИ), менее эффективно.

Нетрудно предположить, что метод оценки риска может быть приоритетным в определенных обстоятельствах, таких как условия принятия управленческих решений в короткие сроки, или недостатка средств для выполнения и проведения ЭЭИ и др. Его достоинством является и тот факт, что оценка риска предполагает прогноз неблагоприятных для здоровья (индивидуума и населения) последствий загрязнения ОС или влияния других вредных средовых факторов, в то время как эколого-эпидемиологические исследования имеют цель - выявление и доказательство уже реализовавшихся 


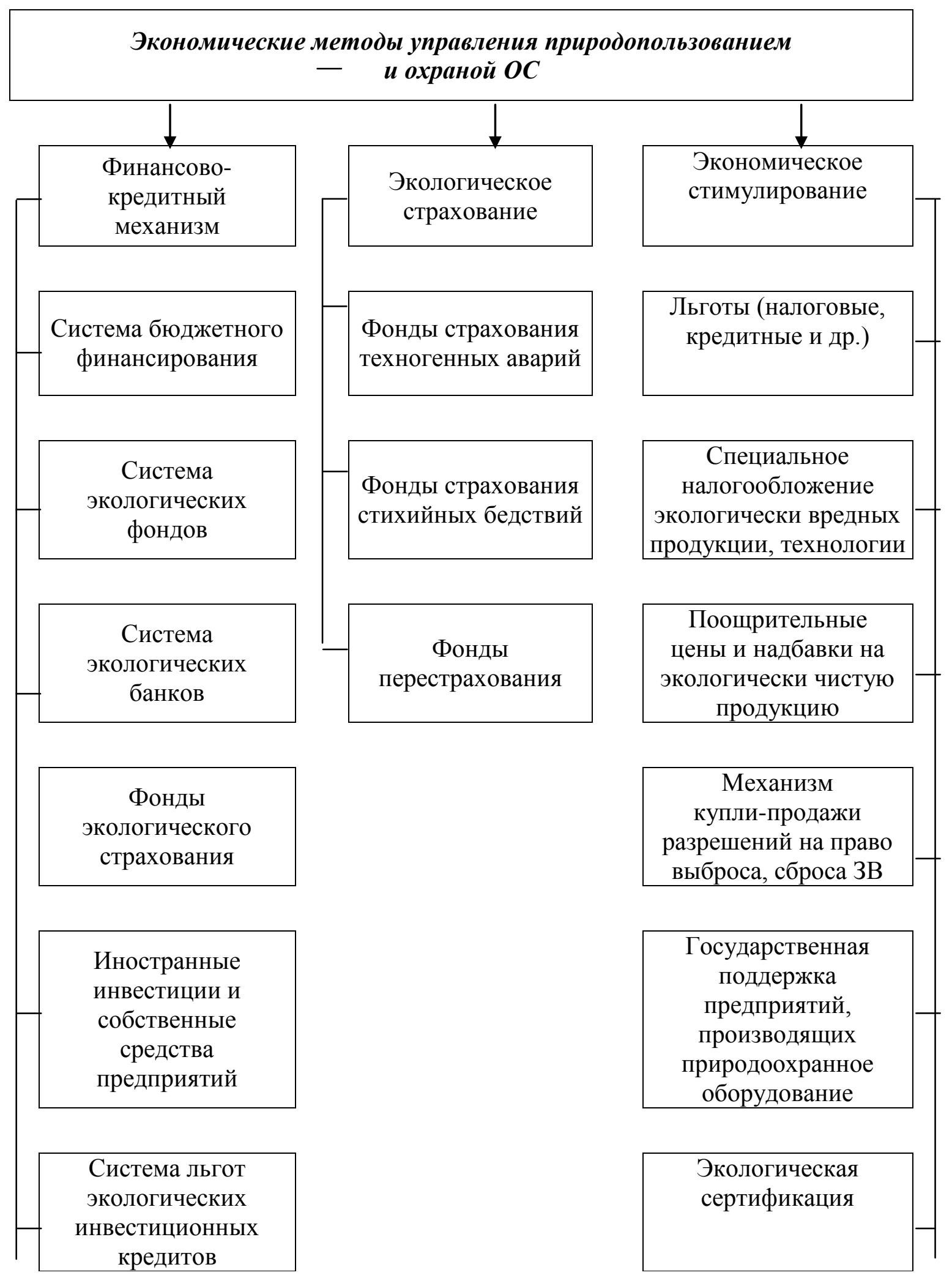

Рис.15. Экономические методы управления природопользованием и охраной ОС [27]

последствий со стороны здоровья населения, подвергающегося или подвергавшегося в прошлом воздействию таких вредных факторов.

Система принятия управленческих решений на региональном уровне, 
ориентированная на приоритеты обеспечения санитарно-эпидемиологического благополучия населения, охраны здоровья и основанная на методологии управления риском, может быть представлена схемой (см. рис. 15), [27].

С «технической» точки зрения приведенная схема позволяет госорганам использовать административные методы управления, совместимые с рыночной хозяйственной системой. Финансовой основой системы регулирования охраны здоровья служит механизм предоставления средств из бюджетов субъектов федерации и их территориальных образований в форме субвенций, субсидий и дотаций в соответствии $\mathrm{c}$ действующим законодательством РФ.

В соответствии с подходами, рассмотренными ранее, оценка предупреждаемых финансовых потерь, связанная с неблагоприятным влиянием на здоровье населения и базирующаяся на двух методах («стоимость болезни», «готовность платить»), по мнению западных и отечественных экспертов, не может быть непосредственно перенесена в российские условия. Поэтому управление охраной здоровья и санитарно-эпидемиологическим благополучием населения (рис. 16) несмотря на применимость к нему «рыночного» подхода оценки риска должна оставаться прерогативой государства. В обосновании позиции следует более подробно рассмотреть подходы к оценке финансовых потерь, применяемых в рамках системы оценки риска.

Первый из методов «стоимость болезни» позволяет усреднить сумму расходов и денежных потерь, связанных с тем или иным заболеванием. В соответствии с ним получаемый расчетный параметр, если иметь в виду практический аспект его применения, должен устанавливаться на основе конкретных исследований для каждого рассматриваемого региона. В условиях малой информативности и экономической нестабильности дать оценку «стоимости болезни» в качестве единого норматива крайне затруднительно. 


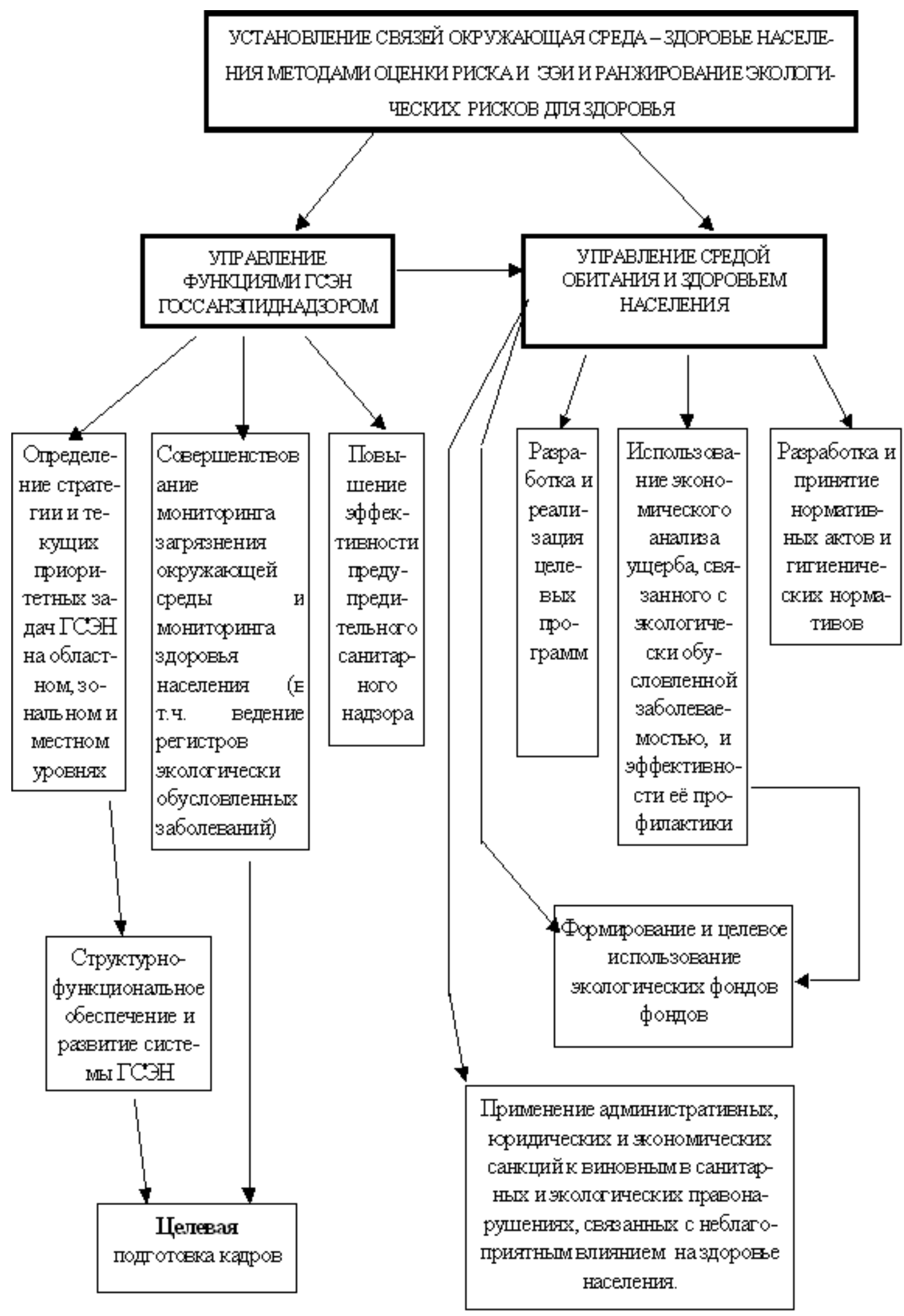

Рис.16. Механизм регулирования санитарного благополучия и охраны здоровья населения 
Второй метод - так называемая «готовность платить» - представляет собой определение возможной cyммы, которую средний представитель населения психологически готов потратить на предупреждение конкретного риска. Эта величина, выясняемая специальными социологическими исследованиями, пока еще не проводившимися в России, безусловно не может быть объективно установлена или перенесена оттуда, где и социальноэкономические условия, и общественный менталитет существенно отличны от российских.

Еще более трудоемкими и сложными являются методы, основанные на измерении экономических потерь, связанных с сокращением продолжительности жизни (в том числе, в нетрудоспособном возрасте), а также с нарушениями репродуктивной функции. Однако на практике вполне возможно положить оцененное число заболеваний или смертей в основу расчета финансового ущерба при проведении экономического анализа по типу «затраты - выгоды» либо при оценке экономической эффективности планируемых природоохранных мероприятий. Именно поэтому метод «затраты - выгоды» представляется более предпочтительным при оценке финансовых потерь, поскольку он отработан на практике в части идентификации затрат и выгод. В работе он принят в качестве основного, так как на сегодняшний день информация для сводных расчетов затрат поступает из данных официальной отчетности.

К государственным и рыночным методам управления нельзя относиться как антиподам. Основная функция государства заключается в отработке отвечающего рыночной системе законодательства, обеспечении условий для его соблюдения, содействии формированию рыночных институтов, разработке и проведении социально-экономической политики. Поэтому допуская совмещение государственно-рыночных методов управления (см. рис. 16) считаем, что оно не противоречит логике развития сложных систем, каковыми являются и социально-экономические. «Рыночная» концепция управления, основанная на положениях риск-анализа, устанавливает индикатором риска 
снижения качества ОС состояние здоровья человека, выраженное с помощью специальных показателей риска.

В системе оценки рисков, имеющей целью установление объективной картины риска на определенной территории, дается количественная оценка риска и ущерба здоровью населения и ОС. Система управления риском рассматривается как деятельность, направленная на снижение уровня рисков экономических потерь объектов различного народно-хозяйственного уровня, обусловленных ухудшением качества ОС.

Проблематика влияния социального аспекта природоохранных проектов на инвестиционную привлекательность региона имеет целью изучение объективной картины риска на определенной территории, т. е. оценку риска. Оценка воздействия загрязняющих веществ на элементы ОС является одной из стадий процесса ощенки риска и представляет собой сложную процедуру, включающую оценку источников и характера выбросов (сбросов), а также путей распределения загрязнителей и воздействия химического вещества, проводимую с целью установления концентраций/доз, при которых может иметь место воздействие на человека. Оценка последствий для здоровья выступает завершающей стадией оценки риска, предполагающей расчет популяционного и индивидуального рисков и оценку в стоимостной форме потерь от ухудшения качества ОС. Именно этот конечный результат, выраженный в форме соцчиального эффекта, дает ориентиры в инвестиционной политике и климате региона, влияет на его инвестиционную привлекательность. Скрытый на первый взгляд социальный эффект, присущий всем природоохранным проектам, является тем потенцииальнылм инструментом инвестициинной политики, который обеспечивает постепенное давление на механизм инвестиционной привлекательности региона (через снижение экологических, социальных рисков и соответственное повышение уровня ЭЭС), создает существенные инвестиционные преимущества.

Таким образом, реализация природоохранных проектов дает решение 
социальных проблем, связанных в первую очередь со здоровьем и санитарноэпидемиологическим благополучием населения, и дополнительно выражается в таких результатах, как:

- повышение уровня соцчиальной безопасности;

- адаптаџии ресурсопотребляющих и загрязняющих производств к общественным потребностям территории;

- снижении негативных последствий на окружающую природную среду, допускаемых в процессе хозяйственной деятельности.

Все перечисленные следствия создают положительное представление о сформированном инвестиционном климате региона и предпочтении общественных потребностей в политике через приоритет реализациии природоохранных проектов. При этом существенно снижаются экологические риски (в терминах методики рейтинговых агентств), социальные и инвестиционные риски и, следовательно, возрастает степень инвестиционной привлекательности региона.

С государственной позиции приоритет реализации природоохранных проектов обеспечивает наиболее рациональное размещение ограниченных инвестиционных ресурсов, поскольку с учетом сопутствующих экологических и социальных эффектов выгоды от их осуществления становятся более ощутимы и сравнимы с затратами на их исполнение. Взаимодействие факторов ЭЭБ и факторов, определяющих инвестиционную политику территории, рассмотрено в виде схемы (рис.17, модифицировано по [36]).

Схема дает представление о том, что интересы территории, связанные с определенным (заданным) уровнем ЭЭБ и состоянием социальной безопасности, являются приоритетными при оценке инвестиционной привлекательности и разработке политики в этой сфере, поскольку формируют среду распространения всех социально-экономических процессов.

Как отмечалось ранее, в процессе оценки инвестиционной привлекательности и климата региона всегда важно выявлять вклад 


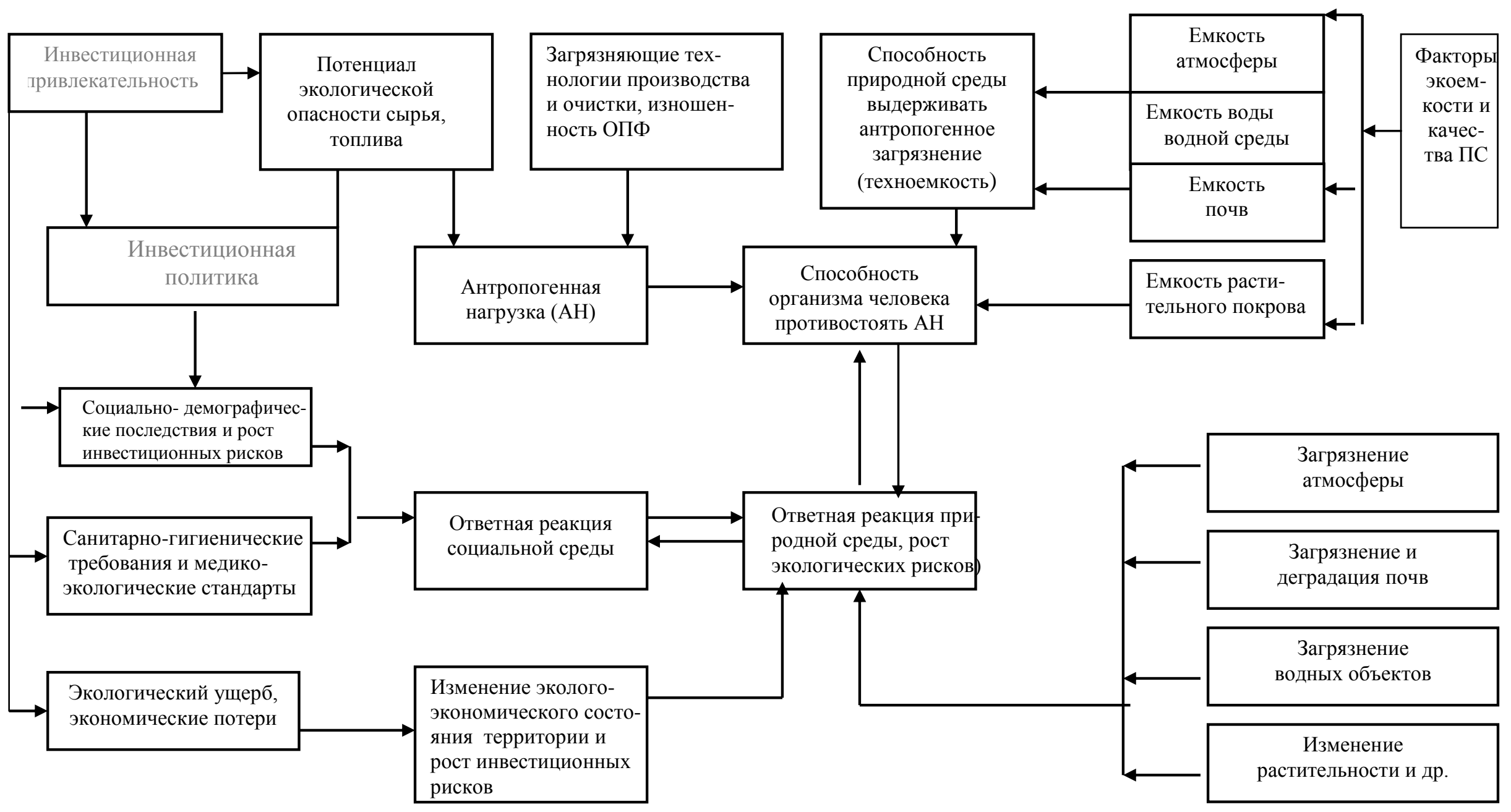

Рис. 17. Схема взаимосвязи факторов эколого-экономического состояния и инвестиционных рисков территории 
социального и экологического факторов. И если влияние экологического фактора может быть учтено через приоритет реализации природоохранных проектов, социального - через систему регулирования санитарного благополучия и охраны здоровья населения.

Для расчета величины социального эффекта, получаемого от внедрения мероприятий, направленных на снижение выбросов в атмосферу, и последующего обоснования его влияния на повышение уровня инвестиционной привлекательности исследуемого региона продолжим рассматривать пример, приведенный в предыдущем разделе.

Оценка риска от загрязнения воздуха предполагает в первую очередь расчет дозы, которая выражается в единицах концентращиии загрязнителя в этом компоненте. Общепринятое определение понятия доза состоит в следующем: доза - основная мера экспозиции, характеризующая то количество вещества, которое воздействует на организм при ингаляции загрязнённого им воздуха, поглощении загрязненной им воды или пищи, контакте кожи с ним.

При оценке важно оценивать не только концентращию вещуества в среде, но и фактор времени. Именно он дает возможность косвенно судить о получаемой дозе, даже если она не может быть определена непосредственно. Для оценки риска, не связанного с профессией, доза обычно рассчитывается на период жизни продолжительностью 70 лет или для конкретного отрезка времени как среднедневная на один килограмм массы тела (мг или мкг/кг-день).

\section{Пример}

В пределах выбранной территории (муниципальное образование - MO

г. Сухой Лог) исследовались группы населения, проживающие в загрязненной зоне ОАО «Сухоложскцемент». В число приоритетных загрязнителей атмосферы МО была включена цементная пыль мелких фракций, поэтому расчет уровня популяционного риска выполнялся от воздействия выбросов мелкодисперсной пыли. В работе величина дозы рассчитывалась как среднесуточное поступление ЗВ в приземный слой, т. е. через массу выбросов. Ныне действующая «Методика определения предотвращенного ущерба», 
утвержденная Председателем Государственного комитета РФ по охране ОС 30.11.1999 г., и Временная методика 1986 г. мало пригодны для определения величины концентрации в приземном слое или среднесуточного поступления 3В, контактирующего с биологической тканью (имея в виду организм человека). Вариантом расчета величины среднесуточного поступления ЗВ на единицу массы человека послужила методика [27].

Основными признаками опасности действия загрязняющих веществ на атмосферный воздух на стадии предварительной оценки воздействия служили такие показатели, как «индекс опасности» [27], определяемый отношением оценки дозы к допустимой среднесуточной дозе (аналог используемого показателя «средняя концентрация примесей в долях ПДК), и показатель оценка экспонированных к уровням.

Согласно Государственному докладу «О состоянии окружающей природной среды и влиянии факторов среды обитания на здоровье населения Свердловской области в 2011 г.» по мелкодисперсной пыли $\left(\mathrm{PM}_{10}\right)$ наблюдалась кратность превышения ПДК (г. Сухой Лог). Доклад и формы 2ТП - воздух отчетности предприятия послужили источником исходных данных для оценки уровня риска. Расчет величины популяционного риска преждевременных случаев смерти выполнен на основе данных по выбросам мелкодисперсной пыли $\left(\mathrm{PM}_{10}\right)$. В соответствии с предложенной методикой [27], если в зоне активного загрязнения не производится замеров концентрации загрязняющих веществ, то приблизительная величина среднесуточного поступления (табл. 37), рассчитанная на единицу веса тела человека, может быть найдена по формуле

$$
C=\frac{\sum m_{i} \cdot V}{h \cdot S \cdot T \cdot M} \cdot f,
$$

где $m_{i}$ - фактическая масса загрязняющего вещества $i$-го вида, выбрасываемая за год, т/год;

$h$ - высота приземного слоя (в расчетах принимается равной 2 м), м;

$f$ - поправка, учитывающая характер рассеивания загрязняющего вещества в атмосфере (безразмерная величина); 
$S$ - площадь зоны активного загрязнения (ЗАЗ), ${ }^{2}$;

$T$ - количество дней в году;

$V$ - объем воздуха, проходящего через легкие человека в течение суток;

$M$ - масса тела человека, 70 кг.

Таблица 37

Исходные данные для оценки среднесуточного поступления пыли

\begin{tabular}{|l|c|c|c|c|}
\hline \multicolumn{1}{|c|}{ Показатель } & Обозн. & $\begin{array}{c}\text { Величина } \\
\text { (до внедрения) }\end{array}$ & $\begin{array}{c}\text { Величина } \\
\text { (после внедрения) }\end{array}$ & $\begin{array}{c}\text { Ед. } \\
\text { изм. }\end{array}$ \\
\hline $\begin{array}{l}\text { Масса выброса пыли } \\
\text { в воздух } \\
\text { Степень очистки }\end{array}$ & $M$ & $3,3 \cdot 10^{12}$ & $3,15 \cdot 10^{12}$ & мг/год \\
\hline
\end{tabular}

Поправка $f$ определена для частиц скоростью оседания менее $1 \mathrm{~cm} / \mathrm{c}$, выбрасываемых после пылеочистки с коэффициентом улавливания свыше $90 \%$, и составила 0,23. Расчет площади активного загрязнения $S$ составил $110 \cdot 10^{6} \cdot \mathrm{m}^{2}$. Для определения величины $S$ организованных источников была использована формула

$$
\mathrm{S}=\pi \cdot\left(\mathrm{r}_{\text {внеш }}-\mathrm{r}_{\text {ВН }}\right)^{2}=110142751 \mathrm{~m}^{2},
$$

где $r_{\text {внеш }}-$ внешний радиус зоны активного загрязнения;

$$
\mathrm{r}_{\text {внеш }}=20 \cdot \varphi \cdot \mathrm{h}^{\prime}=6580,68 \mathrm{M},
$$

где $\varphi$ - поправка на подъем факела выброса в атмосфере;

$$
\varphi=1+\frac{\Delta \mathrm{T}}{75^{0} \mathrm{C}}=3,1,
$$

где $\Delta T$ - среднегодовое значение разности температур в устье источника (трубы) и в окружающей атмосфере, ${ }^{0} \mathrm{C}$. В расчетах принята средневзвешенная величина $\Delta T$, равная 158 (использование средневзвешенной $\Delta T$ допустимо, так как температура в устье основного источника и воздуха близки); $h^{\prime}$ - высота источника (трубы), м; средняя величина ее равна 106,14 м; $r_{\text {вн }}$-внутренний радиус зоны активного загрязнения $r_{\text {вн }}=2 \cdot \varphi \cdot \mathrm{h}^{\prime}=658,07$ м

Расчет популяционного риска от загрязнения неканцерогенными веществами (табл. 38) был выполнен с использованием модели годового 
популяционного коэффициента риска, хотя некоторые авторы и методики используют приведенную выше методику расчета риска канцерогенов с изменением значения фактора потенциала:

$$
\Gamma \Pi К P=C / 0,01 \cdot 0,0059 \cdot 4 / T_{ж},
$$

где 0,0059 - индивидуальный коэффициент риска от воздействия взвешенных

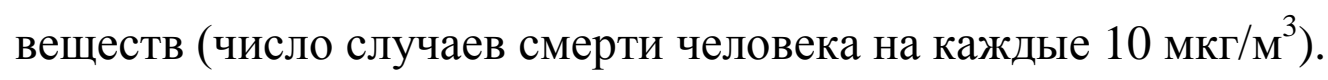

Таблица 38

Расчет популяционного риска от выбросов пыли в г. Сухом Логу

\begin{tabular}{|l|c|c|c|c|}
\hline \multicolumn{1}{|c|}{ Показатель } & $\begin{array}{c}\text { Обозна- } \\
\text { чение }\end{array}$ & $\begin{array}{c}\text { Величина } \\
\text { (до внедрения) }\end{array}$ & $\begin{array}{c}\text { Величина } \\
\text { (после внедрения) }\end{array}$ & Ед. изм. \\
\hline $\begin{array}{l}\text { Концентрация пыли на 1 кг } \\
\text { массы тела }\end{array}$ & $C$ & 0,53 & 0,50 & мг/кг/день \\
\hline $\begin{array}{l}\text { Индивидуальный риск - } \\
\text { годовой }\end{array}$ & $I R$ & $4,9 \cdot 10^{-3}$ & $4,5 \cdot 10^{-3}$ & - \\
\hline Численность населения & ч & \multicolumn{2}{|c|}{$35,7 \cdot 10^{3}$} & чел. \\
\hline Популяционный риск & $P R$ & 175 & 160,65 & - \\
\hline
\end{tabular}

Расчет последствий оценки риска здоровью человека в стоимостной форме основывался на определении финансовых потерь в результате преждевременной смерти. Заболевания, вызванные воздействием исследуемого фактора, приводят к смертельному исходу редко, в силу чего расчет стоимости (затрат) на один случай заболевания, связанный с преждевременной смертью, можно считать достаточно условным.

В данной версии расчет случаев смерти от влияния фактора (мелкодисперсная пыль) выполнен с использованием показателей годового индивидуального риска, фоновой заболеваемости (смертности) и количества лет сокращения продолжительности жизни, соответствующей одному случаю смерти по анализируемому фактору.

В настоящем исследовании для получения укрупненной стоимостной оценки риска здоровью использовались данные работы [27], позволяющие осуществить пересчет индивидуального годового риска в соответствующие дни сокращения продолжительности жизни. 
Согласно методике годовому риску $10^{-4}$ соответствует $1-2$ дня сокращения продолжительности жизни, что в пересчете на 1 случай смерти составляет примерно 30 лет сокращения срока жизни (потерянные годы жизни $\left.=I R \cdot 2 \cdot 4 / 365 \cdot 10^{-4}\right)$.

Экономическая оценка потерь от воздействия мелкодисперсной пыли выполнялась с использованием метода расчета дополнительных случаев смерти к фоновой смертности и применением доходного подхода, учитывающего недополученную величину валового внутреннего (регионального) продукта и сумму недопоступления налогов в бюджеты разного уровня.

Число дополнительных случаев снижения (роста) смертности населения от воздействия мелкодисперсной пыли рассчитано в годовом разрезе, стоимость каждого дополнительного случая смерти определена исходя из величины недополученного среднедушевого дохода и не поступивших сумм налогов в бюджет и внебюджетные фонды. Расчеты приведены в таблицах 39, 40.

Таблица 39

Натуральные показатели ущерба от загрязнения атмосферы

\begin{tabular}{|c|c|}
\hline Фактор воздействия & Дополнительные случаи смерти* \\
\hline Мелкодисперсная пыль $\left(\mathrm{PM}_{10}\right) \mathrm{MO}$ г. Сухой Лог & 15 \\
\hline
\end{tabular}

* Дополнительные случаи смерти определяются исходя из величины годового популяционного риска для не канцерогенных загрязняющих веществ.

Оценка потерь на основе затратного подхода осуществлялась укрупненно c использованием в качестве затрат показателя размер недополученной заработной платы (см. табл.40). В период болезни человеку выплачивается социальное пособие по временной нетрудоспособности, однако в расчетах не учитывается часть дополнительных затрат на приобретение медикаментов и оплату медицинских услуг, которые полностью компенсируют получаемые в период нетрудоспособности выплаты. Таким образом, можно предположить, что реальная величина потерь может оказаться несколько больше, чем расчетная (средний уровень заработной платы принят равным 12000 руб./мес.).

Для природоэксплуатирующих предприятий в условиях ограниченности 
Экономическая оценка стоимости потерь

\begin{tabular}{|c|c|c|}
\hline $\begin{array}{l}\text { Фактор } \\
\text { воздей } \\
\text { ствия }\end{array}$ & Показатель & $\begin{array}{l}\text { Сумма, млн } \\
\text { руб/год }\end{array}$ \\
\hline \multicolumn{3}{|c|}{ Доходный подход к оценке стоимости потерь: } \\
\hline $\begin{array}{c}\text { Мелкодис- } \\
\text { персная } \\
\text { пыль }\end{array}$ & $\begin{array}{l}\text { Недополученный среднедушевой доход: } \\
\text { - до осуществления природоохранных мероприятий; } \\
\text { - после осуществления мероприятий } \\
\text { Недополученные суммы поступлений налогов (ЕСН, НДФЛ) в } \\
\text { бюджет и внебюджетные фонды: } \\
\text { - до осуществления природоохранных мероприятий; } \\
\text { - после осуществления мероприятий } \\
\text { Итого суммарный недополученный доход: } \\
\text { - до осуществления природоохранных мероприятий; } \\
\text { - после осуществления мероприятий }\end{array}$ & $\begin{array}{l}15,1 \\
13,9\end{array}$ \\
\hline
\end{tabular}

природных ресурсов природоохранная деятельность становится приоритетной, не исключая и инвестиционную. Кроме того, если предприятие, такое как ОАО «Сухоложскцемент» является градообразующим (трудоустроено более $30 \%$ трудоспособного населения МО «г. Сухой Лог»), отмеченное приобретает еще большую актуальность.

В примере оценка потерь, выполняемая на базе затратного подхода, осуществлялась с использованием в качестве расходов показателя недополученной заработной платы, расчеты выполнялись на основании официальных данных по среднедушевому доходу (по данным [86]).

Расчет предотвращенного и социального эффектов обеспечивает детальную оценку инвестиционных проектов, осуществляемую для окончательного отбора в портфель реальных инвестиций и формирования долгосрочного инвестиционного бюджета компании. При этом задача финансового управления инвестиционным портфелем, связанная с контролем возврата первоначально авансированного капитала и получения необходимой прибыли, решается успешно даже для капиталоемких проектов, так как при обосновании социальной эффективности снижается цена привлекаемого капитала на долю бюджетного и внебюджетного финансирования. 
Таким образом, представленные результаты свидетельствуют о том, что использование системы отбора по формальным и неформальным критериям и ранжирование по дополнительным показателям, характеризующим экологический, социальный и бюджетный эффекты, позволяет предприятиям, особенно градообразующим, имеющим определенную социально-экономическую ответственность перед жителями МО, решать задачи хозяйственного развития без нарушений, связанных с ростом техногенной нагрузки и ухудшением качества ПС, т. е. с сохранением заданного уровня ЭЭБ.

\section{Вопросы и задания для самопроверки}

1. Опишите доходный подход к определению стоимости лечения от риска заболевания, вызванного ухудшением качества ОС.

2. Дайте характеристику вида затрат, связанных с риском заболевания населения от ухудшения качеств ОС.

3. С помощью каких методов можно определить уровень концентрации ЗВ в приземной слое.

4. Методы определения продолжительности статистической жизни.

5. Метод оценки популяционного риска.

6. Опишите алгоритм экономической оценки стоимости потерь.

7. Характеристика риска здоровью населения, связанного с ухудшением качества жизни населения.

\section{Рекомендуемая литература}

1. Мекуш Г. Е. Экологическая политика и устойчивое развитие: анализ и методические подходы / Г. Е. Мекуш; под ред. С. Н. Бобылева; Кемеровский гос. ун-т. М. : Экономика, 2011. $255 \mathrm{c}$.

2. Оценка загрязнения атмосферы промышленными выбросами : монография / А. Д. Выварец, И. С. Белик, Ю. В. Леонтьева [и др.]. Екатеринбург : ГОУ ВПО УГТУ-УПИ, 2006. $108 \mathrm{c}$.

3. Белик И. С. Социально-экономическое обоснование экологической безопасности региона : монография / И. С. Белик, А. А. Куклин, Н. Л. Никулина. Екатеринбург : ГОУ ВПО УГТУ-УПИ, 2005. $145 \mathrm{c.}$

\section{4. МЕЖДУНАРОДНЫЕ МЕХАНИЗМЫ ЭКОЛОГИЧЕСКОГО РЕГУЛИРОВАНИЯ}

\section{1. Экологические последствия климатических изменений и качества ОС}

Глобальное изменение климата вызывает разбалансированность климатической системы, что проявляется в росте числа и силы всех опасных гидрометеорологических явлений (ОГЯ): наводнений, засух, волн жары и резких 
заморозков, шквальных ветров, сильных снегопадов и т. п.

По оценке Всемирного банка, ежегодный ущерб от различных гидрометеорологических явлений, в число которых входят и последствия изменения климата, в России составляет 30 - 60 млрд руб. [45].

Как сами климатические изменения, так и вызванные ими изменения в ОС влияют на различные сферы деятельности человека, включая экономику. Однако картина этих воздействий достаточно сложна, и часто вторичные эффекты влияют сильнее, чем первичные. Наиболее чувствительны к изменениям климата секторы экономики и объекты, непосредственно зависящие от природноклиматических условий: сельское и лесное хозяйства, системы водоснабжения, здания и инженерные сооружения, а также транспортная инфраструктура территорий с вечной мерзлотой.

Для небольшого количества северных стран мира при глобальном потеплении на $1-1,5{ }^{\circ} \mathrm{C}$ может наблюдаться небольшой положительный нетто-эффект, который при дальнейшем глобальном повышении температуры до $2-3^{\circ} \mathrm{C}$ сменится на отрицательный [45]. В более южных регионах, включая Россию и сопредельные страны, нынешнее потепление ведет к ущербу. При этом главный урон наносят не средние температуры, а рост числа и силы опасных гидрометеорологических явлений: наводнений, ураганов, волн жары, засух и т. п. Предполагается, что потери от этих явлений в ближайшие годы будут расти со скоростью более 0,1% ВВП, а к середине века ежегодные прямые потери от погодных явлений будут составлять 0,5 - 1 \% мирового ВВП [30].

Из-за изменения состояния грунта (оттаивание вечной мерзлоты, повышение уровня грунтовых вод, подтопление и т. п.) будут расти нагрузки на различные инженерные сооружения и в первую очередь трубопроводы, а из-за изменения стока рек и ледового режима - нагрузки на их подводные участки. Это будет приводить к более частым повреждениям и авариям с разливами нефти, выбросами газа, особенно в северных районах страны, где проходит большая часть трубопроводов. Изменения климата влекут за собой значительные 
негативные последствия, особенно ярко проявляющиеся в таких ранимых местах, как Арктика, регионы, подверженные опустыниванию, островные и прибрежные территории с высокой плотностью населения [22].

Происходит как прямое влияние за счет увеличения числа дней с аномально высокими и низкими температурами, количества наводнений, штормов, тайфунов, так и косвенное, опосредованное влияние экологических или социально-экономических факторов (увеличение площади засушливых земель, уменьшение объемов качественной питьевой воды, появление «новых» болезней и др.). Одним из самых главных косвенных факторов можно считать энергетическую бедность. Основными жертвами глобальных энергетических проблем являются беднейшие слои населения. Имея ограниченный доступ к энергии как таковой, они несут бремя недостаточного доступа и к иным благам, которые дает наличие энергии. Современное энергоснабжение необходимо, чтобы помочь бедным слоям населения в соблюдении их прав на здоровье (пища и способы ее приготовления), на образование, на тендерное равенство, на сохранение привычного образа жизни (развитие сельского хозяйства). Все эти права в полной мере можно обеспечить только с помощью чистых энергетических технологий [40].

Региональные особенности разных стран по-своему высвечивают социальные последствия воздействия на здоровье жителей этих регионов в результате изменения климата. Так, для жителей северных регионов, а в особенности Арктики, изменения коснутся традиционного природопользования коренных народов Севера (например, возможности охоты и рыболовства). Возникнут проблемы с сохранностью продуктов питания, что может увеличить количество инфекционных заболеваний. Южные регионы подвергнутся засухам с увеличением числа инфекционных заболеваний. Социальные последствия опустынивания проявятся в увеличении заболеваемости и смертности населения, так как возрастет количество пыли, перемещаемой с пустынных и полупустынных территорий. Другие социальные последствия - недостаток воды для питьевых и 
хозяйственно-бытовых целей, засолений сельскохозяйственных почв, нехватка местных продуктов питания, а в результате - недостаток белков, микроэлементов и других необходимых компонентов питания [45].

Социальные последствия наводнений проявляются в виде разрушения жилищного хозяйства, инженерных структур, производственных помещений, энергосетей и в возрастании опасности появления вспышек инфекционных заболеваний.

Оценка социальных потерь - очень сложная задача, по которой пока нет полной информации, но уже понятно, что потери будут большими и миллионам людей придется сменить место проживания. Оценки потерь и возможных миграционных потоков населения для стран Азии и Африки говорят, что это не $1-2$ или даже 5 \% ВВП, предсказываемые для развитых стран, и в частности для России [45]. При этом видно, что потери намного выше вероятного экономического роста в 3 - 6 \%, что предполагает «откат в прошлое», причем достаточно быстрыми темпами.

\section{Парниковый эффект}

Парниковый эффект - разогрев нижних слоев атмосферы, вследствие способности атмосферы пропускать коротковолновую солнечную радиацию, но задерживать длинноволновое тепловое излучение земной поверхности. Водяной пар задерживает около 60\% теплового из лучения Земли и углекислый газ - до 18\%. В отсутствие атмосферы средняя температура земной поверхности была бы $23^{\circ} \mathrm{C}$, а в действительности она составляет $+15^{\circ} \mathrm{C}[46]$.

Парниковому эффекту способствует поступление в атмосферу антропогенных примесей (диоксида углерода, метана, фреонов, оксида азота и др.). За последние 50 лет содержание углекислого газа в атмосфере возросло с 0,027 до 0,036 \%. Это привело к повышению среднегодовой температуры на планете на 0,6 ${ }^{\circ} \mathrm{C}$. Существуют модели, согласно которым, если температура приземного слоя атмосферы поднимется еще на $0,6{ }^{\circ} \mathrm{C}-0,7{ }^{\circ} \mathrm{C}$, произойдет интенсивное таяние ледников Антарктиды и Гренландии, что приведет к 
повышению уровня воды в океанах и затоплению до 5 млн км² низменных, наиболее густо заселенных равнин [22].

Отрицательные для человечества последствия парникового эффекта заключаются в повышении уровня Мирового океана в результате таяния материковых и морских льдов, теплового расширения океана и т. п. Это приведет к затоплению приморских равнин, усилению абразионных процессов, ухудшению водоснабжения приморских городов, деградации мангровой растительности и т. п. Увеличение сезонного протаивания грунтов в районах с вечной мерзлотой создаст угрозу дорогам, строениям, коммуникациям, активизирует процессы заболачивания и т. д. [46].

Положительные для человечества последствия парникового эффекта связаны с улучшением состояния лесных экосистем и сельского хозяйства. Повышение температуры приведет к увеличению испарения с поверхности океана, это вызовет возрастание влажности климата, что особенно важно для аридных (сухих) зон. Повышение концентрации углекислого газа увеличит интенсивность фотосинтеза, а значит, продуктивность диких и культурных растений.

\section{Разруиение «озонового слоя»}

Озоновый слой (озоносфера) - слой атмосферы с наибольшей концентрацией озона $\left(\mathrm{O}_{3}\right)$ на высоте 20 - 25 км. Содержащееся в озоновом слое количество озона невелико: в приземных условиях атмосферы (при давлении 760 мм и температуре $+20^{\circ} \mathrm{C}$ ) он образовал бы слой толщиной всего 3 мм [21]. В атмосфере озон образуется из кислорода под действием ультрафиолетового излучения. «Озоновая дыра»- значительное пространство в озоносфере планеты с заметно пониженным (до 50 \% и более) содержанием озона. Считается, что основной причиной возникновения «озоновых дыр» является значительное содержание в атмосфере фреонов. Фреоны (хлорфторуглероды) - высоколетучие, химически инертные у земной поверхности вещества, широко применяемые в производстве и быту в качестве хладоагентов (холодильники, кондиционеры, рефрижераторы), пенообразователей и распылителей (аэрозольные упаковки). Фреоны, 
поднимаясь в верхние слои атмосферы, подвергаются фотохимическому разложению с образованием окиси хлора, интенсивно разрушающей озон.

Истощение озонового слоя в атмосфере Земли приводит к увеличению потока ультрафиолетовых лучей на земную поверхность. Ультрафиолетовые лучи в небольших дозах необходимы живым организмам (стимуляция роста и развития клеток, бактерицидное действие, синтез витамина D и т. д.), в больших дозах губительны из-за способности вызывать раковые заболевания и мутации.

\section{Антропогенные воздействия}

Атмосфера и последствия изменения ее качества. Антропогенное воздействие на атмосферу проявляется, прежде всего, в загрязнении атмосферного воздуха (прил. 1).

Справка [12].

Загрязнение атмосферного воздуха - привнесение в него или возникновение в нем новых (обычно не характерных для него) вредных химических, физических, биологических агентов. Оно может быть естественным (природным) и антропогенным (техногенным).

Естественное загрязнение воздуха вызвано природными процессами (вулканическая деятельность, ветровая эрозия, массовое цветение растений, дым от лесных и степных пожаров и др.).

Антропогенное загрязнение связано с выбросом ЗВ в результате деятельности человека. По агрегатному состоянию выбросы вредных веществ в атмосферу классифицируются следующим образом: 1) газообразные (диоксид серы, оксиды азота, оксид углерода, углеводороды и др.); 2) жидкие (кислоты, щелочи, растворы солей и др.); 3) твердые (тяжелые металлы, канцерогенные вещества, органическая и неорганическая пыль, сажа, смолистые вещества и др.).

Главные (приоритетные) антропогенные загрязнители (поллютанты) атмосферного воздуха - диоксид серы $\left(\mathrm{SO}_{2}\right)$, диоксид азота $\left(\mathrm{NO}_{2}\right)$, оксид углерода (CO), твердые частицы (пыль, сажа, зола). На их долю приходится около 98 \% выбросов вредных веществ в атмосферу. Кроме них в атмосферу поступает еще более 70 наименований вредных веществ: тяжелые металлы (свинец, ртуть, кадмий и др.); углеводороды $\left(\mathrm{C}_{\Pi} \mathrm{H}_{\mathrm{T}}\right)$, среди которых наиболее опасен бенз(а)пирен, альдегиды (в первую очередь формальдегид), сероводород, токсичные летучие растворители (бензины, спирты, эфиры) и др. [21]. 
Особо опасным видом загрязнения атмосферы является радиоактивное загрязнение, вызванное радиоактивными изотопами. Его источники производство и испытания ядерного оружия, отходы и аварийные выбросы АЭС.

\section{Экологические последствия загрязнения атмосферы [21]}

Физиологическое воздействие на человеческий организм загрязнителей атмосферного воздуха различно. Оксид углерода (угарного газа) прочно соединяется с гемоглобином крови, что препятствует нормальному снабжению органов и тканей кислородом, в результате ослабляются процессы мыслительной деятельности, замедляются рефлексы, возникает сонливость, возможны потери сознания и смерть от удушья. Диоксид кремния $\left(\mathrm{SiO}_{2}\right)$, содержащийся в пыли, вызывает тяжелое заболевание легких - силикоз. Диоксид серы, соединяясь с влагой, образует серную кислоту, которая разрушает легочную ткань. Оксиды азота раздражают и разъедают слизистые оболочки глаз и легких, увеличивают восприимчивость к инфекционным заболеваниям, вызывают бронхит и пневмонию. Если в воздухе содержатся совместно оксиды азота и диоксид серы, то возникает эффект синергизма, т. е. усиление токсичности всей газообразной смеси. Частицы размером менее 5 мкм способны проникать в лимфатические узлы, задерживаться в альвеолах легких, засорять слизистые оболочки.

Незначительные по объему выбросы такие, как бенз(а)пирен, соединения свинца, кадмия, ртути, мышьяка, кобальта, фосфора и др., могут оказывать воздействие, растянутое во времени. Они обладают канцерогенным действием, вызывают дефекты у новорожденных, снижают иммунитет, угнетают кроветворную и нервную системы и т. д.

Кислотные дожди. Кислотный дождь - дождь или снег, подкисленный до $\mathrm{ph}$ $<5,6$ из-за растворения в атмосферной влаге антропогенных выбросов (оксиды серы, оксиды азота, хлороводород, сероводород и др.). Отрицательное воздействие кислотных дождей на растительность проявляется как в прямом биоцидном воздействии на растительность, так и в косвенном через снижение $\mathrm{pH}$ почв. Выпадение кислотных дождей приводит к ухудшению состояния и гибели 
целых лесных массивов, а также снижению урожайности многих сельскохозяйственных культур. Кроме того, отрицательное воздействие кислотных дождей проявляется в закислении пресноводных водоемов. Снижение рН воды вызывает сокращение запасов промысловой рыбы, деградацию многих видов организмов и всей водной экосистемы, а иногда и полную биологическую гибель водоема. Негативные последствия кислотных дождей зафиксированы в Канаде, США, Европе, России, Украине, Белоруссии и других странах.

Смог. Смог - ядовитая смесь дыма, тумана и пыли. Различают два типа смога: лондонский и лос-анджелесский. Лондонский (зимний) смог образуется зимой в крупных промышленных центрах при неблагоприятных погодных условиях: отсутствии ветра и температурной инверсии. Температурная инверсия проявляется в повышении температуры воздуха с высотой в слое $300-400$ м вместо обычного понижения. В результате дым и загрязняющие вещества (пыль, оксиды серы и углерода) не могут подняться вверх и рассеяться, а образуют туманную завесу. Лос-анджелесский (летний, фотохимический) смог возникает летом также при отсутствии ветра и температурной инверсии, но обязательно в солнечную погоду. Он образуется при воздействии солнечной радиации на оксиды азота и углеводороды, поступающие в воздух в составе выхлопных газов автомобилей и выбросов предприятий. В результате образуются высокотоксичные загрязнители - фотооксиданmы, состоящие из озона, органических пероксидов, пероксида водорода, альдегидов и т. д. Смог вызывает обострение респираторных заболеваний, раздражение глаз, ухудшение физического состояния и т. д. вплоть до летального исхода. В 1952 г. в Лондоне от смога за две недели погибло более 4000 человек [46].

\section{Гидросфера и последствия изменения ее качества}

Антропогенное воздействие на гидросферу проявляется в загрязнении и истощении вод. Загрязнение может быть естественнылм (природным) и антропогенным (техногенным).

Справка [21] 
Загрязнение вод - привнесение или возникновение в них новых (обычно не характерных для них) вредных химических, физических, биологических агентов. Загрязнение вод проявляется в изменении физических и органолептических свойств (нарушение прозрачности, окраски, запахов, вкуса), увеличении содержания сульфатов, хлоридов, нитратов, тяжелых металлов, сокращении растворенного в воде кислорода воздуха, появлении радиоактивных элементов, болезнетворных бактерий и других загрязнителей.

Естественное загрязнение вод вызвано природными процессами. Например, загрязнение вод в результате извержения вулканов, водной и ветровой эрозии, абразии (разрушения) берегов, засоление пресных вод солеными и т. д.

Антропогенное загрязнение связано с поступлением загрязняющих веществ в гидросферу в результате деятельности человека. Наиболее распространено химическое и биологическое загрязнения, в меньшей степени радиоактивное, механическое и тепловое (прил. 2).

\section{Экологические последствия истощения вод}

Истощуение вод - недопустимое сокращение их запасов в пределах определенной территории (для подземных вод) или уменьшение минимально допустимого стока (для поверхностных вод). Истощуение подземных вод возникает в результате интенсивной добычи подземных вод в районах водозаборов, а также значительного водоотлива при строительстве шахт и карьеров. Это нарушает естественно сложившуюся взаимосвязь поверхностных и подземных вод. Истощение подземных вод приводит к ухудшению речного стока, иссушению родников, ручьев и небольших рек, снижению уровня подземных вод, иссушению и опустыниванию территорий, гибели растительности. Истощуение поверхностных вод возникает в результате безвозвратного изъятия вод рек и других водных объектов на орошение, промышленное производство, коммунально-бытовые нужды и т. д. Это приводит к снижению поверхностного стока, истощению малых рек и озер, регрессии морей, дефициту пресной воды.

Справка [21] 
На территории России поверхностный сток воды распределяется крайне неравномерно. Изъятие на хозяйственные цели большого количества воды из впадающих в водоемы рек может привести к их истощению. Примером может служить регрессия (отступление) Аральского моря. Его уровень с 60-х гг. XX в. катастрофически понижается в связи с недопустимым объемом забора воды из питающих Арал рек - Амударьи и Сырдарьи. Осушенное дно Аральского моря становится сегодня крупнейшим источником пыли и солей. В дельте Амударьи и Сырдарьи на месте гибнущих тугайных лесов и тростниковых зарослей появляются бесплодные солончаки.

Загрязнение пресноводных экосистем приводит к подавлению жизнедеятельности, плодовитости и гибели гидробионтов, нарушению пищевых связей, снижению устойчивости экосистем, эвтрофикации и т. д.

Химическое загрязнение наиболее распространенное, стойкое и далеко распространяющееся загрязнение гидросферы. При осаждении на дно водоемов или при фильтрации в грунтовые воды вредные химические вещества сорбируются частицами пород, окисляются и восстанавливаются, выпадают в осадок и т. д.

Биологическое загрязнение вод вызывается патогенными микроорганизмами, бактериями, вирусами, простейшими, грибами, мелкими водорослями.

Радиоактивное загрязнение - загрязнение вод радионуклидами. Оно опасно даже при очень малых концентрациях радиоактивных веществ, особенно «долгоживущих» и подвижных в воде радиоактивных элементов (стронций-90, уран, радий-226, цезий и др.). Радионуклиды попадают в поверхностные водоемы при сбрасывании радиоактивных отходов, захоронении их на дне и др., в подземные воды - в результате просачивания вглубь земли вместе с атмосферными водами или в результате взаимодействия подземных вод с радиоактивными горными породами.

Механическое загрязнение (загрязнение вод механическими примесями) твердыми частицами (песок, ил, шлам и др.) свойственно в основном поверхностным водам. При этом наиболее значительно ухудшаются органолептические показатели воды. 
Тепловое загрязнение - это повышение температуры вод в результате их смешивания с более нагретыми поверхностными или технологическими водами (тепловых и атомных электростанций). При повышении температуры происходит изменение газового и химического состава вод, что ведет к размножению анаэробных бактерий и выделению ядовитых газов - сероводорода, метана. Одновременно происходит «цветение» воды вследствие ускоренного развития фитопланктона.

Эвтрофикация вод - повышение биологической продуктивности водных объектов в результате накопления биогенных элементов (азота, фосфора, калия и др.) под воздействием естественных и антропогенных факторов. Негативным последствием эвтрофикации является ухудшение физико-химических условий среды обитания рыб и других гидробионтов за счет массового развития фитопланктона, снижения содержания кислорода в воде, разложения отмерших организмов и токсичности продуктов их распада. Антропогенная эвтрофикация связана с поступлением в водоемы значительного количества биогенных веществ - азота, фосфора и других элементов в виде удобрений, моющих веществ, отходов животноводства, атмосферных аэрозолей и т. д. Сроки протекания антропогенной эвтрофикации составляют несколько десятилетий.

Цветение вод - массовое развитие фитопланктона, вызывающее изменение окраски воды от зеленой и желто-бурой до красной. Оно обусловлено значительным поступлением в водоемы биогенных элементов (азота, фосфора, калия и др.). «Kрасныле приливы» - массовое развитие пирофитовых водорослей, связанное с чрезмерным сбросом в океан органических веществ. Они неоднократно наблюдались у берегов Индии, Австралии, Японии, Черного моря.

\section{Почва и последствия изменения ее качества}

Негативное антропогенное воздействие на почву проявляется в ее деградации (ухудшении качества почвы в результате снижения плодородия) и полном разрушении. Эти процессы могут происходить как в результате природных явлений (природное изменение условий почвообразования, 
извержение вулканов, ураганы и др.), так и в результате нерациональной хозяйственной деятельности человека (прил. 3).

\section{Экологические последствия загрязнения почв [21]}

Водная эрозия - процесс разрушения почвенного покрова под действием талых и дождевых вод. В результате водной эрозии сокращается или уничтожается гумусовый горизонт почвы, что приводит к уменьшению содержания гумуса, азота, фосфора, калия и других питательных элементов, а также ухудшению структуры и уплотнению почвы. Помимо разрушения наиболее плодородной части почвы водная эрозия сопровождается рядом других неблагоприятных явлений: потеря талых и дождевых вод, уменьшением запасов воды в почве, расчленением полей, заилением рек, оросительных и дренажных систем, других водоемов. Развитие водной эрозии зависит от ряда факторов: мощность снегового покрова и интенсивность его таяния; количество, интенсивность и величина капель дождевых осадков; характер рельефа; гранулометрический состав и структура почв; наличие и характер растительного покрова.

Ветровая эрозия (дефляц̧ия) - процесс разрушения почвенного покрова под действием ветра. Водная эрозия распространена преимущественно в районах недостаточного увлажнения и низкой относительной влажности воздуха. Развитие ветровой эрозии зависит от следующих факторов: характер рельефа; гранулометрический состав и структура почв; наличие и характер растительного покрова. Виды ветровой эрозии: пьльные бури и повседневная дефлящия. Пыльные бури повторяются раз в 3 - 20 лет, уносят до 15 - 20 см поверхностного слоя почвы. Повседневная дефляция более медленно, но регулярно разрушает почву.

Промышиленная эрозия почв - разрушение почвенного покрова промышленной деятельностью человека, а именно отчуждение почв городами, поселками, дорогами, линиями электропередачи и связи, трубопроводами, карьерами, водохранилищами, свалками и т.д.

Дегумификащия почв - уменьшение содержания и запасов органического вещества. Дегумификация наблюдается при распашке целинных почв. Этот 
процесс наиболее интенсивен в первые 5 - 10 лет, а через 30 - 50 лет стабилизируется.

Почвоутомление и истощение почв - процессы, происходящие в почвах в результате длительного возделывания одного вида сельскохозяйственных культур. Например, длительное возделывание подсолнечника приводит к обеднению почвы калием.

Вторичное засоление, осолонцевание и слитизация почв. Процессы вторичного засоления, осолонцевания почв возникают на орошаемых почвах при несовершенных проектах и нарушении правил эксплуатации ирригационных систем. Вторичное засоление - засоление почв при орошении почвы минерализованными водами или пресными водами в результате подъема уровня минерализованных грунтовых вод. Вторичное осолонцеевание - комплекс процессов, вызванных содовым засолением: изменение реакции почвенного раствора (рН 9 - 11), увеличение содержания натрия в составе поглощенных катионов, пептизация коллоидов, повышение мобильности органического вещества, ухудшение водно-физических свойств почвы, прежде всего структуры. Вторичная слитизация - ухудшение структуры почв вследствие содового засоления. Причинами деградации орошаемых почв служат бездренажное орошение, большие потери воды на фильтрацию, превышение оросительных норм, неконтролируемая подача воды, полив минерализованной водой.

Вторичная кислотность почв - кислотность почв ниже оптимальной реакции почв, которая для многих сельскохозяйственных растений находится в интервале рН 5,5 - 8; вторичная кислотность возникает в результате выбросов в атмосферу соединений кислот промышленного, транспортного и другого происхождения.

Затопление, разрушение и засоление почв водами водохранилищ. Создание водохранилищ сопровождается развитием комплекса негативных процессов, приводящих к деградации почвенного покрова: затопление пойменных и надпойменных террас, подъем уровня грунтовых вод и подтопление почв, аб- 
разия берегов и засоление дельт, размыв и уничтожение почв приморских дельт, загрязнение и содовое (щелочное) засоление вод и почв и др.

Промышиленное загрязнение почв - результат осаждения паров, аэрозолей, пыли или растворенных соединений поллютантов на поверхность почвы с атмосферными осадками.

Сельскохозяйственное загрязнение почв - результат неправильного применения пестицидов, внесение сверхнормальных доз минеральных и органических удобрений, отходов и стоков животноводческих ферм.

Радиоактивное загрязнение почв - накопление в почве радионуклидов в результате ядерных взрывов, аварийных выбросов на атомных предприятиях, утечки радиоактивных материалов, захоронении отходов атомной промышленности.

Деградащия ландиафтов районов с распространением многолетней мерзлоты. Эти территории отличаются крайней неустойчивостью к воздействию антропогенных факторов. Неупорядоченное движение транспорта, перевыпас и другие процессы приводят к нарушению растительного покрова, что обуславливает протаивание мерзлых грунтов, развитие эрозионных процессов, разрушение почвенного покрова.

Учет последствий антропогенного загрязнения, т. е. экологических проблем территории при обосновании ее социально-экономического развития осуществляется посредством включения в систему выбора ограничений экологического и экономического характера. К ограничениям экономического и экологического характера при обосновании планов хозяйственного роста территории относят: виды хозяйственной деятельности, развитие которых неприемлемо и/или нежелательно для данной территории, международные обязательства в контексте трансграничного загрязнения. Однако, как показывает практика, использование данного инструмента по неполному перечню ограничений без оценки последствий (табл. 41) недостаточно для обеспечения экологически безопасного развития территории. 
Матрица проблемных ситуаций

\begin{tabular}{|c|c|c|}
\hline $\begin{array}{l}\text { Причина возникновения } \\
\text { проблемной ситуации }\end{array}$ & Проблемная ситуация & Последствия \\
\hline $\begin{array}{l}\text { Планирование использо- } \\
\text { вания невозобновляемых } \\
\text { ресурсов }\end{array}$ & $\begin{array}{l}\text { Истощение запасов при- } \\
\text { родных минерально- } \\
\text { сырьевых ресурсов }\end{array}$ & $\begin{array}{l}\text { Прекращение деятельности предпри- } \\
\text { ятий, использующих эти ресурсы, } \\
\text { потеря рабочих мест. Замедление } \\
\text { темпов экономического роста }\end{array}$ \\
\hline$\cdots$ & $\cdots$ & $\ldots$ \\
\hline $\begin{array}{l}\text { Несовершенство органи- } \\
\text { зации и управления } \\
\text { природопользованием }\end{array}$ & $\begin{array}{l}\text { Противоречия между плани- } \\
\text { рованием развития хозяйст- } \\
\text { венной деятельности и } \\
\text { улучшением качества ОС }\end{array}$ & $\begin{array}{c}\text { Промышленная экспансия, } \\
\text { ухудшение качества ОС }\end{array}$ \\
\hline
\end{tabular}

Выявление вероятных воздействий на природную среду и оценка экологических и связанных с ними социальных и экономических последствий дает возможность разработать перечень приоритетных эколого-экономических проблем территории. Подобный перечень формируется на основе матрицы проблемных ситуаций (см. табл. 43, [35]).

Таким образом, процедуру разработки матрицы проблемных ситуаций целесообразно выполнять на этапе диагностики и включать самостоятельным блоком в систему принятия стратегических решений социальноэкономического развития региона.

\section{Вопросы и задания для самопроверки}

1. Основные антропогенные воздействия на атмосферу.

2. Основные антропогенные воздействия на гидросферу.

3. Основные антропогенные воздействия на почву.

4. Приоритетные антропогенные вещества, загрязняющие атмосферу.

5. Приоритетные антропогенные вещества, загрязняющие водные ресурсы и почву.

6. Порядок формирования приоритетных эколого-экономических проблем региона.

\section{Рекомендуемая литература}

1. Акимова Т. А. Экономика устойчивого развития : учеб. пособие /Т. А. Акимова, Ю. Н. Мосейкин. М. : ЗАО Изд-во «Экономика», 2009. 430 с.

2. Масленникова И. С. Управление экологической безопасность и рациональным использованием природных ресурсов : учебник / И. С. Масленникова, В. В. Горбунова. СПб. : СПбГИЭУ, 2011. 566 с.

3. Колесников С. И. Экология : учеб. пособие / С. И. Колесников. - 3-е изд. М.: Издво «Дашков и К ${ }^{0} »$; Ростов н/Д: Академцентр, 2009. 384 с. 


\section{2. Формы международного экологического сотрудничества}

Последнее десятилетие характеризуется повышенным вниманием мирового сообщества к проблеме изменения климата, что находит подтверждение в создании специализированных международных организаций, таких, как Секретариат Рамочной конвенции ООН об изменении климата и Киотского протокола, Межправительственная группа экспертов по изменению климата (МГЭИК) и др. В феврале 2005 г. вступил в силу Киотский протокол первое глобальное соглашение по предотвращению изменения климата и др.

На сегодняшний день одной из теорий изменения климата является антропогенное воздействие на ОС. Информация об этом аккумулируется, в частности, в оценочных докладах МГЭИК. Так, в ноябре 2007 г. вышел Четвертый оценочный доклад МГЭИК, в котором подведен итог 6-летней работы сотен ученых из десятков стран мира. В нем отражены самые последние научные выводы о наблюдаемых изменениях климата, их причинах и последствиях в т. ч. и на региональном уровне, прогнозы предстоящих климатических изменений; содержатся рекомендации по возможным адаптационным мерам и смягчению негативных последствий. В этом докладе говорится, что с 90 \%-й вероятностью наблюдаемые изменения климата связаны с деятельностью человека, в первую очередь - сжиганием углеродного ископаемого топлива (т. е. нефти, газа, угля и др.), промышленными процессами, а также сведением лесов - естественных поглотителей $\mathrm{CO}_{2}$ из атмосферы [45].

Парниковые газы, включенные в биогеохимический круговорот, являются естественными для атмосферы Земли, и до начала индустриальной эпохи их концентрация находилась в определенных пределах. Рост концентрации парниковых газов после начала индустриальной эпохи, согласно теории антропогенного изменения климата, связан с тем, что поступающий в OC антропогенный поток парниковых газов, очевидно, превысил способность системы к самовосстановлению. Ситуация усугубилась снижением продуктивной емкости биогеохимического круговорота веществ в связи с 
массовой вырубкой лесов, естественных поглотителей $\mathrm{CO}_{2}$ атмосферы. Результатом превышения поступающих в ОС парниковых газов (в особенности, углекислого газа, $\mathrm{CO}_{2}$ ) над способностью ОС к их ассимиляции стало нарушение основных структурных и функциональных свойств ОС, что привело к началу процессов изменения климата [42].

Bce вышесказанное позволяет полагать, что способность ОС к улавливанию и переработке антропогенных выбросов парниковых газов является неотъемлемой частью ее ассимиляционного потенциала, и может характеризоваться как углеродная техноемкость территории.

Углеродная техноемкость территории (УTT) - это часть ассимиляционного потенциала биосферы, отражающая самовосстановительный потенциал природной системы и количественно равная максимальному объему антропогенных выбросов парниковых газов, которую может уловить и переработать в течение длительного времени совокупность всех реципиентов и экологических систем территории без нарушения ее основных свойств [32].

Углеродную техноемкость территории предлагается оценивать на основе документа «Руководящие принципы национальных инвентаризаций парниковых газов межправительственной группы экспертов по изменению климата (2006 г.)» [45] и принимать равной способности лесов, многолетних насаждений и пастбищ территории поглощать углерод в процессе жизнедеятельности. Углеродную техноемкость регионов предлагается рассчитывать на основе данных о площади лесов, многолетних насаждений и пастбищ и их удельной поглощающей способности.

Правовой основой использования Целевых экологических инвестиций является Рамочная конвенция ООН по изменению климата и Киотский протокол. Киотский протокол - международный документ, принятый в Киото (Япония) в декабре 1997 г. в дополнение к Рамочной конвенции ООН об изменении климата (РКИК), и вступивший в силу в феврале 2005 г., представляет собой первое в мире глобальное экологическое соглашение по предотвращению изменений климата от выбросов парниковых газов. 
Согласно Киотскому протоколу, индустриально развитые страны и страны с переходной экономикой, приведенные в Приложении В к Киотскому протоколу, взяли на себя обязательства по сокращению (либо ограничению) выбросов парниковых газов в 2008 - 2012 гг. на 5,2 \% по сравнению с 1990 г.

Первый бюджетный период осуществления протокола начался 1 января 2008 г. и продлится пять лет, до 31 декабря 2012 г., после чего на смену ему придет новое соглашение, обсуждение которого велось в декабре 2009 г. на Конференции ООН по проблемам глобального изменения климата в Копенгагене (Дания). Для того, чтобы страны могли достигать целевых показателей по снижению выбросов парниковых газов, Киотским протоколом предусмотрено ряд механизмов гибкости (ст. $6,12,17)$ для достижения взятых странами обязательств.

- совместное осуществление проектов - любая Сторона, включенная в Приложение I, может передавать или приобретать единицы сокращения выбросов, полученные в результате осуществления проектов, направленных на сокращения антропогенных выбросов парниковых газов или на увеличение их поглощения в любом секторе экономики (ст. 6);

- механизм чистого развития (МЧР) - Стороны Приложения I могут использовать для целей выполнения обязательств сертифицированные сокращения выбросов, полученные в результате осуществления проектов на территории стран, не входящих в Приложение I, - в развивающихся странах (ст. 12);

- торговля квотами на выбросы парниковых газов - Стороны, включенные в Приложение В Киотского протокола, могут участвовать в торговле выбросами для целей выполнения своих обязательств (рис. 18).

В рамках механизмов гибкости Стороны могут передавать друг другу часть национальной квоты на выбросы парниковых газов (торговля квотами) или приобретать единицы сокращенных по проектам МЧР и проектов совместного осуществления (ПСО) выбросов. Для учета передаваемых углеродных единиц используется тонна $\mathrm{CO}_{2}$ эквивалента, умножаемая для 
каждого парникового газа на соответствующий коэффициент в соответствии с его потенциалом глобального потепления.

Таким образом, Киотский протокол инициировал создание нового международного углеродного рынка. Несмотря на то, что первый период действия Протокола (2008 - 2012 гг.) начался недавно, углеродный рынок существует уже несколько лет. Так, проекты МЧР по снижению выбросов парниковых газов, осуществляющиеся на территории развивающихся стран за счет инвестиций со стороны промышленно развитых стран, к настоящему времени получили широкое распространение благодаря тому, что сделки на передачу углеродных единиц в рамках МЧР могут заключаться с 2000 г. В мире реализуется множество таких проектов: в Китае, Индии, странах Латинской Америки, а сделки по ним составляют до млрд долл. США.

Два других механизма Киотского протокола - торговля квотами на выброс парниковых газов и проекты совместного осуществления - начали действовать с 2008 г. Они осуществляются между промышленно развитыми странами и странами с переходной экономикой.

Россия, в соответствии с Киотским протоколом, не должна была превышать в среднем за 2008 - 2012 гг. уровень выбросов 1990 г. (в 2013 г. Россия не продлила свое участие в протоколе), [45]. Для Российской Федерации была выделена квота в 3,2 млрд тонн $\mathrm{CO}_{2}$ экв, которая превышает способность лесов и сельскохозяйственных земель поглощать углерод, но с другой стороны, позволяет в полной мере использовать имеющийся резерв квот для участия в механизмах Киотского протокола и повышения энергоэффективности экономики на перспективу.

Россия свои количественные обязательства выполнила, при этом у нее оставался избыток квот для продажи (рис. 19). Большинство других стран Приложения I к РКИК, скорее всего, столкнется с невозможностью выполнения своих количественных обязательств по снижению выбросов парниковых газов исключительно за счет реализации внутренних политики и мер, и поэтому 
будут вынуждены использовать механизмы гибкости Киотского протокола и взаимодействовать с другими странами.

В связи с тем, что Россия являлась страной Приложения I, а также в связи с тем, что на территории России не создан механизм торговли квотами, интегрированный в систему торговли квотами других стран $(E C)$, особый интерес для нее представляет совместное осуществление проектов в рамках ст. 6 Киотского протокола.

Проекты совместного осуществления и их возможности для финансирования природоохранных мероприятий

Проектом совместного осуществления (CO) может быть любой проект или мероприятие, приводящие к сокращению выбросов парниковых газов, которые были оформлены и зарегистрированы в соответствии с руководящими принципами ст. 6 Киотского протокола и последующими решениями Совещания Сторон Киотского протокола. Проект совместного осуществления предполагает участие развитых стран, принявших на себя обязательства по ограничению выбросов парниковых газов, в реализации проектов, приводящих к сокращению выбросов парниковых газов и/или увеличению их абсорбции в другой стране, также взявшей на себя аналогичные обязательства. Одна из стран Приложения в таком случае будет выступать в роли инвестора, а другая в роли принимающей Стороны. 


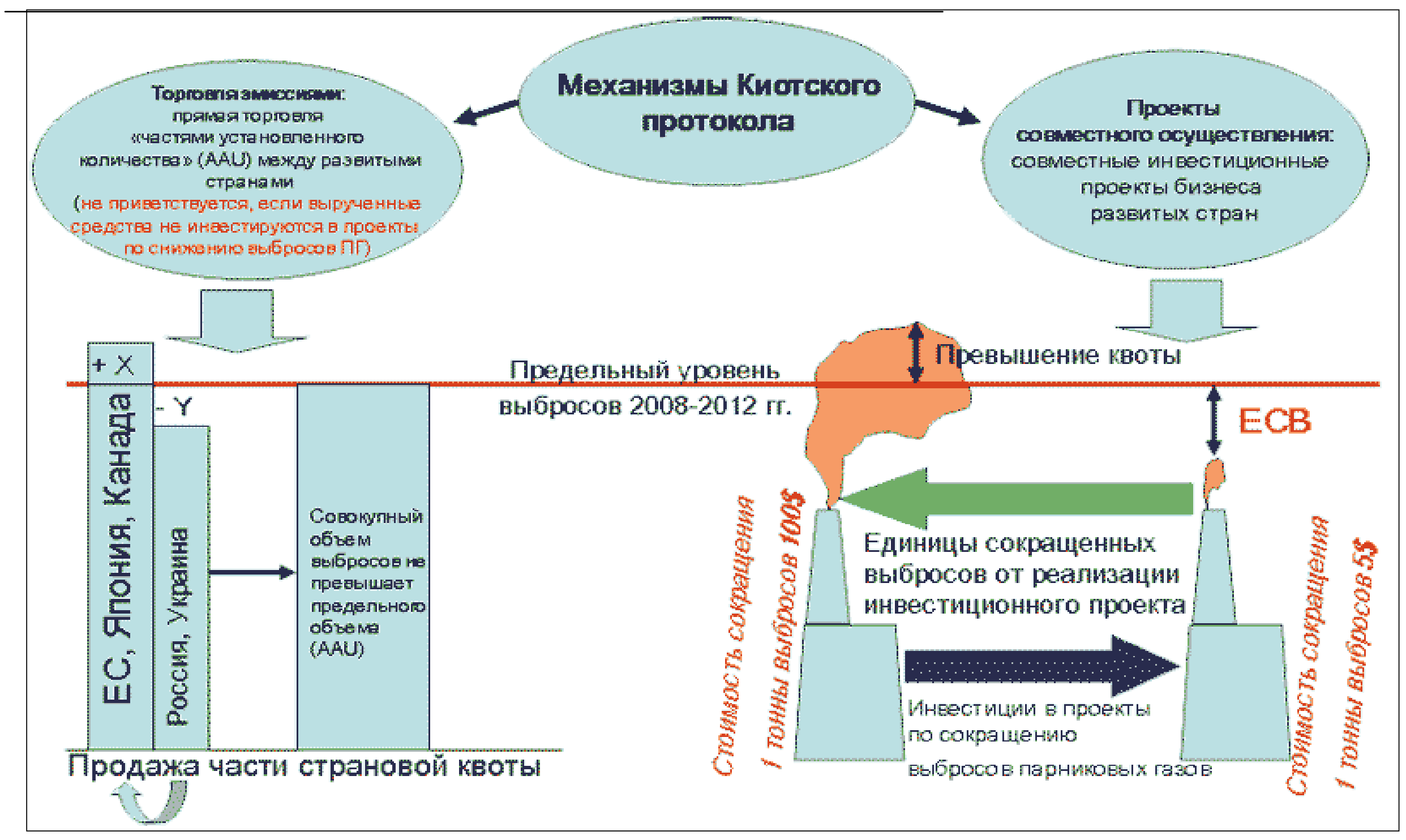

Рис. 18. Механизмы гибкости Киотского протокола [32] 
После реализации проекта, страна-инвестор получает образовавшиеся единицы сокращения выбросов парниковых газов $(E C B)$. Как правило, принимающей страной являются страны с переходной экономикой, по той причине, что данные страны обладают большим запасом единиц сокращения выбросов парниковых газов по сравнению с базовым, 1990 г., в виду структурных преобразований в экономике, вызвавших снижение объема производства и выбросов парниковых газов. Участие может быть как в виде передачи оборудования, технологий, опыта, так и финансовым (соинвестирование проекта).

Интерес индустриально развитых стран из Приложения I к осуществлению ПСО на территории России связан не только с большим запасом единиц сокращения выбросов парниковых газов (ПГ), который есть у России. Также этот интерес обусловлен и тем, что повышение энергоэффективности и снижение карбоноемкости производства на предприятиях промышленно развитых стран в настоящее время представляется либо дорогостоящим, либо вовсе невозможным из-за отсутствия в современном мире более совершенных технологий. При этом штрафы за сверхнормативные выбросы ПГ в индустриально развитых странах высоки.

В свою очередь на многих российских предприятиях до сих пор применяются старые энергоемкие технологии и оборудование. В настоящее время энергоемкость экономики России превышает среднемировой показатель в 2,3 раза, а средний показатель для стран $E C$ - в 3,2 раза (рис. 20). Потенциал энергосбережения в России оценивается в 39-47\% текущего потребления энергии, из них две трети приходится на топливно-энергетический комплекс и энергоемкие отрасли промышленности, и около четверти - на жилищнокоммунальное хозяйство (рис. 21). 


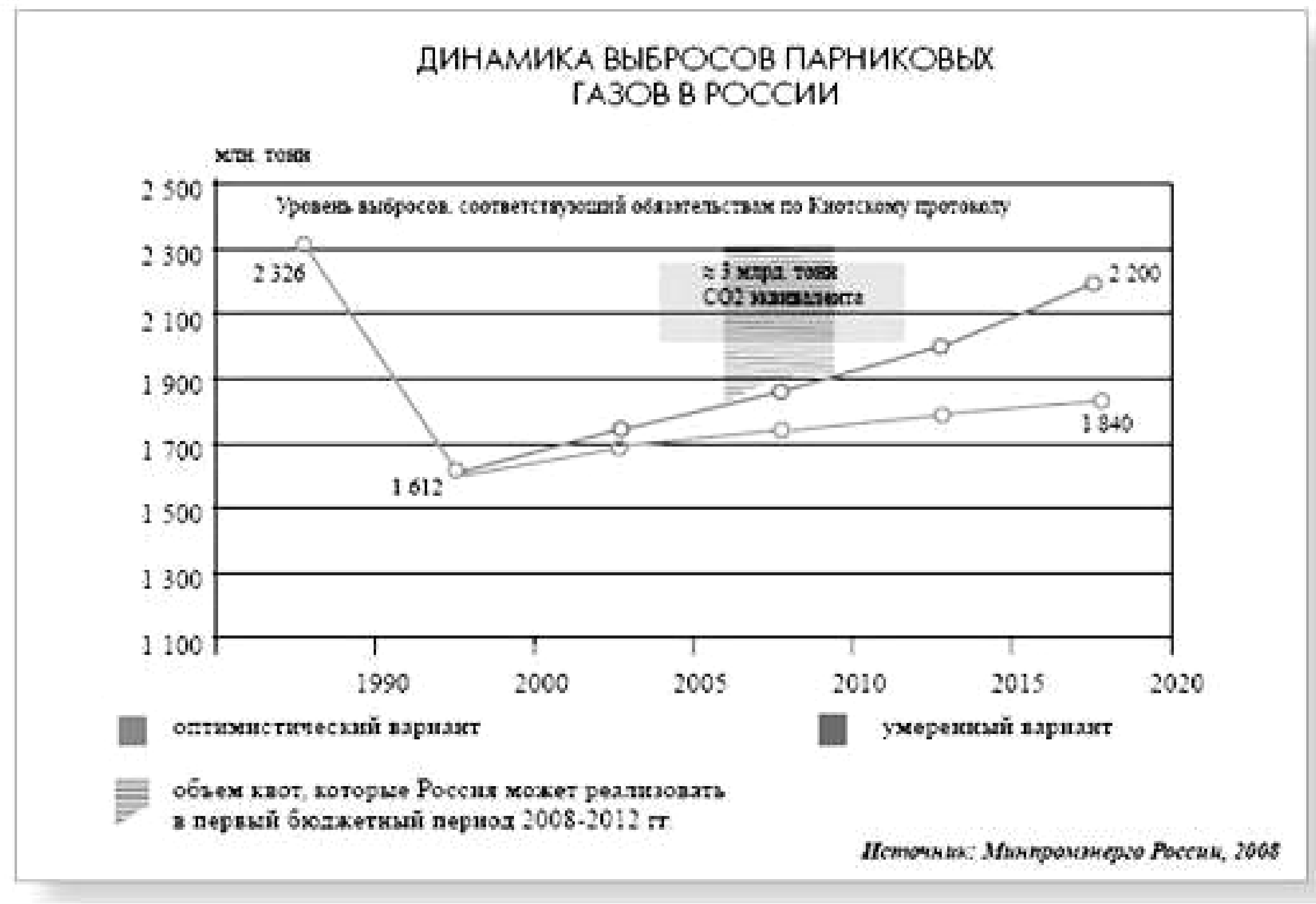

Рис. 19. Динамика выбросов парниковых газов в России [45] 
Таким образом, при сравнении удельных затрат на сокращение выбросов парниковых газов в различных странах и штрафов за превышение квот эмиссий ПГ, имеет место прямой экономический интерес в осуществлении потенциальных ПСО на территории России со стороны других стран, при большом запасе у России единиц сокращения выбросов (табл. 42).

Таблица 42

Удельные затраты в странах на специализированные мероприятия по сокращение выбросов парниковых газов на собственном производстве [46]

\begin{tabular}{|l|c|c|}
\hline \multicolumn{1}{|c|}{ Название страны } & $\begin{array}{c}\text { Значение } \\
\text { показателя }\end{array}$ & Ед. изм. \\
\hline Япония & $100-300$ & долл./тонну \\
\hline Западная Европа & $65-200$ & долл./тонну \\
\hline США, Канада & $20-150$ & долл./тонну \\
\hline Россия & $1-20$ & долл./тонну \\
\hline $\begin{array}{l}\text { Стоимость разрешений/сертификатов на выбросы на } \\
\text { европейском углеродном рынке }\end{array}$ & $20-35$ & долл./тонну \\
\hline $\begin{array}{l}\text { Штраф за превышение квот эмиссии парниковых газов (до } \\
\text { 2008 г.) }\end{array}$ & 54 & долл./тонну \\
\hline \begin{tabular}{l} 
Штраф за превышение квот эмиссии (после 2008 г.) \\
\hline
\end{tabular} & 140 & долл./тонну \\
\hline
\end{tabular}

Актуальность реализации проектов совместного осуществления для России и Свердловской области, занимающей лидирующие позиции по выбросам ПГ среди всех субъектов РФ, очевидна и заключается в следующем [32]:

- возможности привлечения дополнительных иностранных инвестищии на безвозвратной основе для финансирования энергосберегающих проектов, которые не только снижают потребление невозобновляемых ископаемых видов топлива, но и сокращают выбросы вредных веществ в атмосферу (помимо $\mathrm{CO}_{2}$ ), выделяющихся при сжигании топлива;

- привлечении иностранных передовых технологий $u$ опыта, в том числе по охране ОС;

- снижении износа основных производственных фондов, в том числе и природоохранного назначения; 
ЭНЕРГОЕМКОСТЬ ВАЛОВОГО ВНУТРЕННЕГО ПРОДУКТА СТРАН МИРА ПО ПАРИТЕТУ ПОКУПАТЕЛЬНОЙ СПОСОБНОСТИ ВАЛЮТ

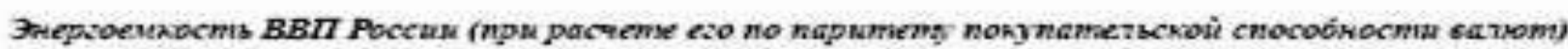
rpeesssucerm:

coedreunpocoù mokasametb o 2,3 pase

cryanev EC \& 3,2 pase

I yx $1000 \mathrm{USD}$

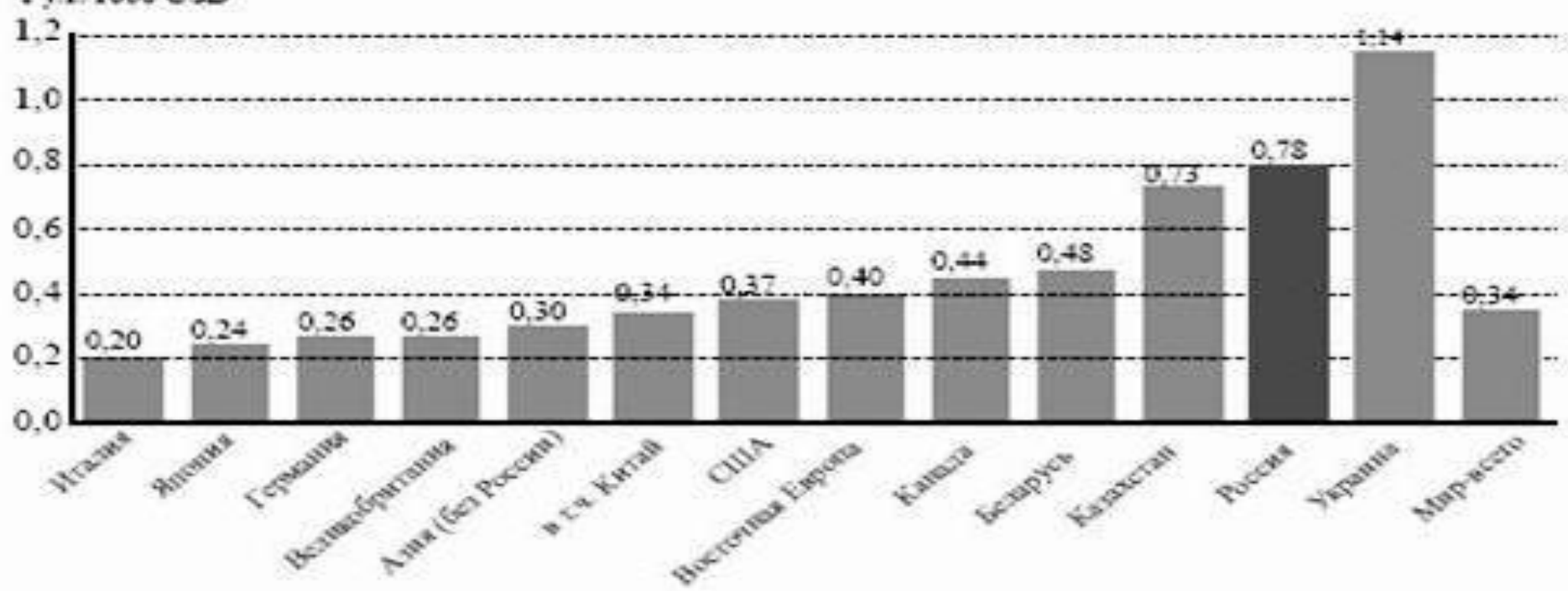

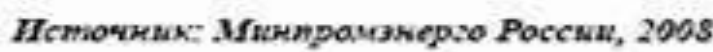

Рис. 20. Энергоемкость ВВП стран мира по паритету покупательной способности валют [10] 


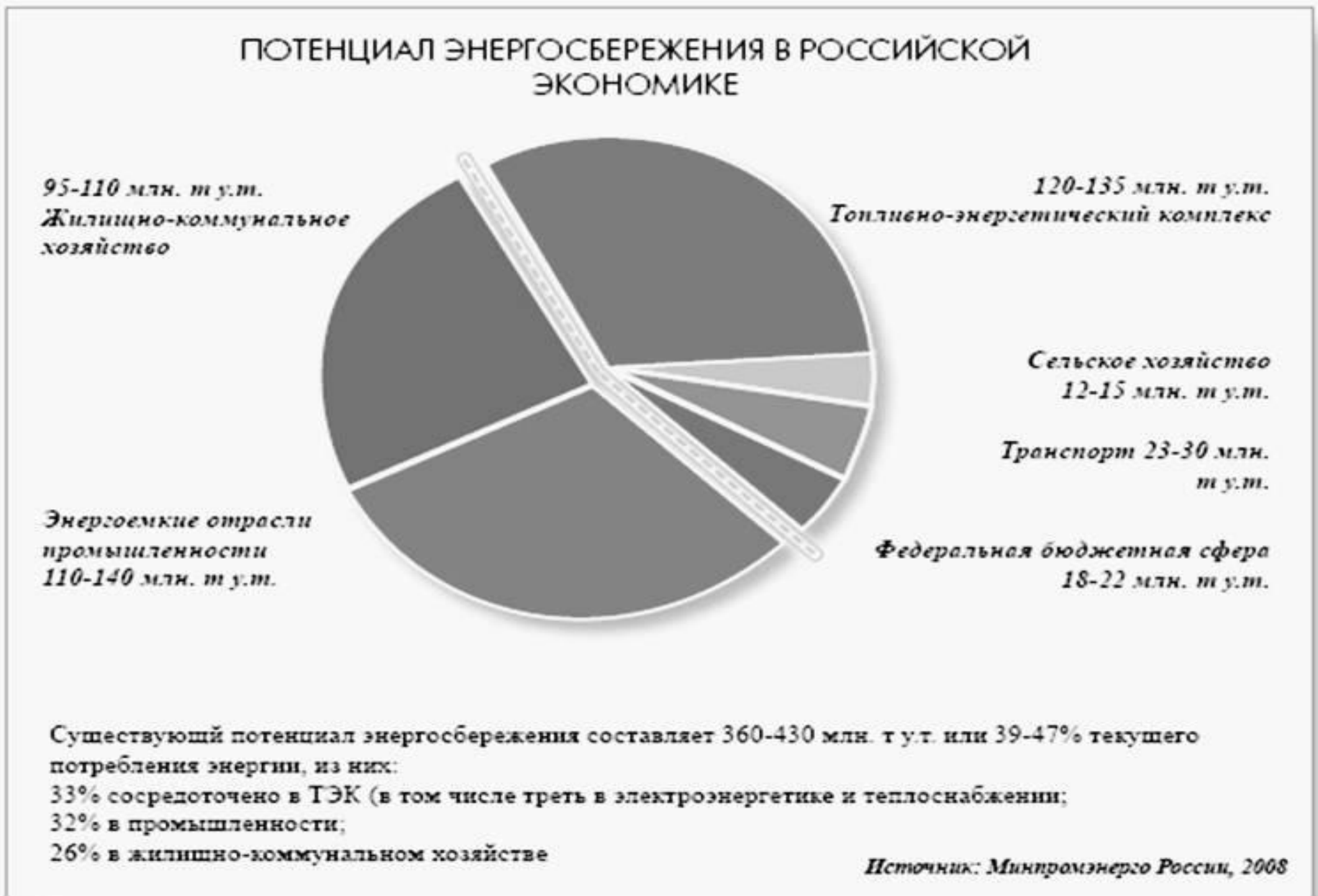

Рис. 21. Потенциал энергосбережения России [46] 
- снижении антропогенного воздействия на ОС, улучшении экологической ситуации и повышении качества жизни.

Реализации проектов $\mathrm{CO}$ на предприятиях мешает плохая информированность собственников бизнеса, незнание возможностей Киотского протокола.

В России Министерство экономического развития и Сбербанк к началу 2012 г. все-таки разработали схему утверждения проектов СО (табл. 43).

Таблица 43

Этапы реализации проектов совместного осуществления на территории РФ

\begin{tabular}{|l|l|}
\hline Этап 1 & $\begin{array}{l}\text { Отбор проектов и их идентификация как возможных ПСО, разработка концепции } \\
\text { проекта (Рrојесt Idea Note - PIN) }\end{array}$ \\
\hline Этап 2 & $\begin{array}{l}\text { Выбор «углеродного» инвестора (покупателя) и соглашение с ним об } \\
\text { организации ПСО, подписание протокола о намерениях или иного документа } \\
\text { такого же рода. Завершение этапа означает начало ПСО }\end{array}$ \\
\hline Этап 3 & Разработка специализированного проектно-технического документа (ПТД) \\
\hline Этап 4 & Детерминация (экспертиза) ПтД независимой аккредитованной организацией \\
\hline Этап 5 & $\begin{array}{l}\text { Прохождение национальных процедур одобрения и регистрации ПСО, } \\
\text { установленных Правительством РФ (Приказ МЭР от 23 ноября 2009 г № } 485 \\
\text { «Об утверждении правил конкурсного отбора заявок, подаваемых в целях } \\
\text { утверждения проектов, осуществляемых в соответствии со ст. 6 Киотского } \\
\text { протокола к Рамочной конвенции ООН об изменении климата », Постановление } \\
\text { Правительства РФ от 28 октября 2009 № 843 «О мерах по реализации ст. } 6 \\
\text { Киотского протокола к Рамочной конвенции ООН об изменении климата») }\end{array}$ \\
\hline Этап 6 & $\begin{array}{l}\text { Разработка проекта контракта купли-продажи сокращенных выбросов между } \\
\text { владельцем проекта и покупателем выбросов (ЕRРА) }\end{array}$ \\
\hline Этап 7 & $\begin{array}{l}\text { Утверждение и регистрация проекта Комитетом по надзору за ПСО (ЈISC- } \\
\text { официальный орган Киотского протокола) }\end{array}$ \\
\hline Этап 8 & Ежегодная верификация снижений выбросов аккредитованной организацией \\
\hline
\end{tabular}

Прохождение национальных процедур одобрения и регистрации ПСО регламентировалось двумя основными документами. Прежде всего, это Постановление Правительства РФ от 28 октября 2009 № 843 «О мерах по реализации ст. 6 Киотского протокола к Рамочной конвенции ООН об изменении климата». Данное Постановление определяет общий порядок утверждения и проверки хода реализации ПСО, который представлен на рис. 27 и состоит в следующем:

1. На сайте оператора углеродных единиц - Сбербанка России - в разделе «Конкурсы» размещается информация о начале конкурса по отбору 
проектов совместного осуществления, которая содержит данные о категориях источников ПГ, предельном объеме $E C B$, требованиях к составу и содержанию заявок, сроках подачи заявок;

2. Заинтересованные предприятия подают заявки на участие в конкурсе по отбору проектов совместного осуществления. Заявка в общем виде включает в себя: проектную документацию установленной формы $(P D D)$; положительное экспертное заключение на проектную документацию, подготовленное аккредитованной независимой организацией; обоснование соответствия заявляемых параметров критериям энергетической и экологической эффективности; материалы, подтверждающие соответствие заявителя проекта установленным требованиям (непроведение в отношении заявителя процедуры банкротства, отсутствие просроченной задолженности по налогам, сборам и другим обязательным платежам, наличие в праве собственности или на ином вещном праве объектов, на которых осуществляются или могут осуществляться проекты);

3. Оператор углеродных единиц в течение 5 рабочих дней со дня приема заявок проводит их оценку на соответствие правилам конкурсного отбора, направляет заявителю решение о принятии заявки к рассмотрению или мотивированный отказ;

4. Проведение экспертизы поданных заявок (экспертизу заявок проводит Экспертный совет, состав и регламент работы которого согласовывается с Минэкономразвития), срок проведения экспертизы не превышает 45 дней;

5. Протокол о результатах экспертизы направляется в Минэкономразвития (координационный центр), который принимает окончательное решение об утверждении проектов и доводит до заявителей проектов решение об утверждении проектов;

6. Инвестор проекта предоставляет в координационный центр и оператору углеродных единиц ежегодно, до 30 сентября года, следующего за отчетным, отчет о ходе реализации проекта, которое включает в себя также экспертное заключение аккредитованной независимой организации; 
7. По результатам положительной экспертизы отчета в течение 5 рабочих дней координационным центром выполняется ввод в обращение ЕСВ в количестве, соответствующему проектному сокращению выбросов ПС;

8. Предприятие по договору передает $E C B$ инвестору в обмен на углеродные единицы.

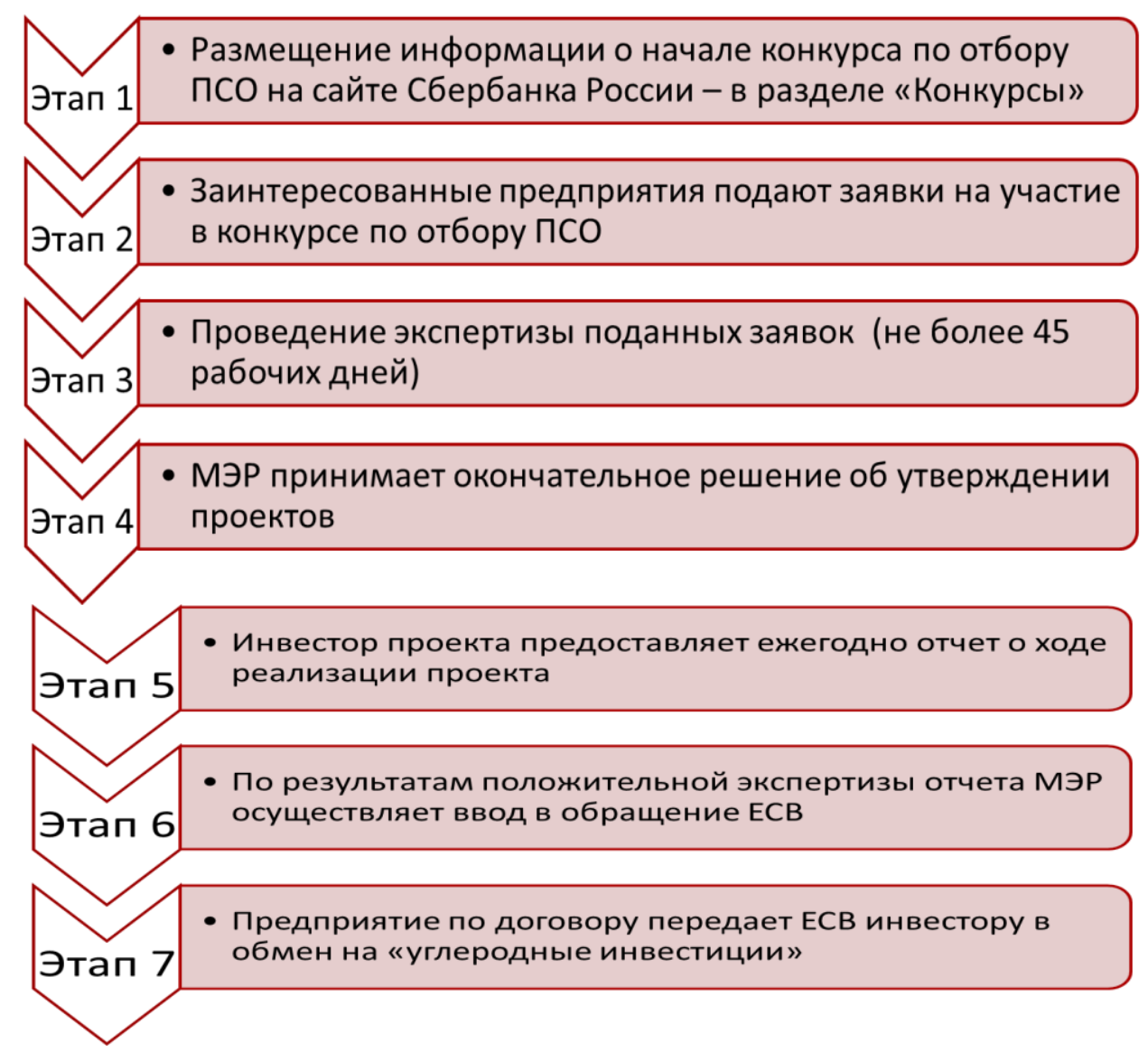

Рис. 22. Этапы прохождения национальных процедур одобрения и регистрации ПСО [45]

Второй документ, определяющий национальную процедуру одобрения и регистрации ПСО - это Приказ Минэкономразвития от 23 ноября 2009 г. № 485 «Об утверждении правил конкурсного отбора заявок, подаваемых в целях утверждения проектов, осуществляемых в соответствии со ст. 6 Киотского протокола к Рамочной конвенции ООН об изменении климата» регламентирует порядок осуществления конкурсного отбора проектов совместного осуществления. Основные положения конкурсного отбора состоят в следующем: 1) по каждому конкурсному отбору предельный объем единиц сокращения выбросов, который может быть введен в обращение, 30 млн тонн $\mathrm{CO}_{2}$ экв; 2) предметом экспертизы заявок является сравнительная оценка заявок 
на основании установленных критериев отбора, по результатам которой заявкам присваивается оценка в баллах; 3 ) критерии отбора заявок:

- критерий энергетической и экологической эффективности (к1), определяемый величинами относительного сокращения потребления энергетических ресурсов, относительного сокращения уровней воздействия на ОС до и после реализации проекта; баллы от 1 до 5;

- критерий оценки технического и финансового потенциала (к2), определяемый наличием у инвестора необходимых для реализации проекта технических средств и технологий и (или) договоров с компетентными организациями, а также финансовых средств (собственных или привлеченных) в объеме, необходимом для реализации проекта в соответствии с проектной документацией; баллы от 1 до 5;

- критерий оценки экономического и социального эффекта реализации проекта (к3), определяемый соответствием планируемых результатов проекта решениям Правительства РФ в области инновационного развития экономики и социальной сферы, а также решениям Комиссии при Президенте РФ по модернизации и технологическому развитию экономики; баллы от 0 до 3.

Общий оценочный балл заявки определяется произведением баллов по каждому из критериев отбора заявок.

$$
M=51 \cdot 52 \cdot 53
$$

где: М - общий оценочный вес заявки;

Б1 - баллы по критерию к1;

Б2 - баллы по критерию к2;

Б3 - баллы по критерию к3.

В соответствии с Постановлением Правительства РФ от 28 октября 2009 г. № 843 «O мерах по реализации ст. 6 Киотского протокола к Рамочной конвенции ООН об изменении климата», утверждение Проектов совместного осуществления производится Министерством экономического развития РФ. На Сбербанк России возлагалась функция оператора углеродных единиц, который производит конкурсный отбор ПСО, обеспечивает финансирование 
деятельности, связанной с передачей и приобретением углеродных единиц, а также получает полномочия по участию в действиях, ведущих к получению, передаче или приобретению единиц сокращения выбросов ПГ.

Таким образом, России, разработав механизмы экономического стимулирования природоохранных мероприятий за счет привлечения дополнительных средств в рамках Киотского протокола, не продлила свое участие в рамках протокола. Однако возможности по изменению ситуации сохраняются.

\section{Целевые экологические инвестиции как способ использования}

\section{предусмотренных Киотским протоколом инструментов}

Целевые экологические инвестиции (ЦЭИ) осуществляются в соответствии со ст. 17 Киотского протокола: «Стороны, включенные в приложение $B$, участвуют в торговле выбросами для целей выполнения своих обязательств по ст. 3. Любая такая торговля дополняет внутренние действия для целей выполнения определенных количественных обязательств по ограничению и сокращению выбросов согласно настоящей статье». Таким образом, на основании ст. 17, страна может приобрести дополнительные квоты на выбросы у тех стран приложения В, чьи выбросы окажутся меньше установленного уровня, и кто решит продать избыток своей квоты. При этом одна страна продает часть своей квоты, а другая ее покупает [45].

Идея ЦЭИ разрабатывалась несколько лет. Впервые она была четко сформулирована в докладе «Киотский протокол и российская энергетика» (второе издание), опубликованном Институтом энергетической стратегии Минэнерго России в 1999 г. Затем ее принципы анализировались в исследовании Всемирного банка «Национальная стратегия Российской Федерации в сокращении эмиссий парниковых газов» (NSS-1) в 1998 - 1999 гг. и академической литературе. В августе - декабре 2001 г. в рамках деятельности, координируемой и финансируемой Всемирным банком, Бюро экономического анализа Министерства экономического развития и торговли России подготовило научное исследование возможностей российского участия 
в международной торговле квотами, в том числе, были рассмотрены и различные аспекты ЦЭИ.

На тот период времени Правительство России впервые официально сформулировало концепцию увязки торговли квотами с мерами по сокращению эмиссий и озвучило ее на шестой Конференции сторон (КС-6) в Гааге в ноябре 2000 г. На продолжении КС-6, состоявшемся в Бонне, концепция ЦЭИ была еще раз одобрена на высшем уровне при переговорах России и $E C$.

ЦЭИ - это специфический способ использования предусмотренных Киотским протоколом инструментов (ПСО, Торговля квотами), предполагающий передачу (изначально на межгосударственном уровне) Единиц установленного количества (ЕУК) в обмен на Целевые экологические инвестиции, направленные на осуществление природоохранных мероприятий.

ЦЭИ изначально рассматривались как комбинация торговли квотами и ПСО. Основным отличием ЦЭИ от ПСО является то, что при реализации ПСО средства получает непосредственно то предприятие, которое реализует проект, a иностранный инвестор получает определенное количество единиц сокращения выбросов, образовавшихся в результате реализации проекта. При осуществлении схемы ЦЭИ, средства первоначально получает Правительство, которое затем направляет их на предприятия как цзелевые инвестициии природоохранных проектов, при этом отсутствует жесткие процедурные требования, присущие ПСО. Отличие ЦЭИ от торговли квотами состоит в том, что при осуществлении торговли квотами отсутствует механизм регулирования использования полученных доходов.

В силу вышеуказанных причин ЦЭИ обладает несколькими преимуществами как перед ПСО, так и перед торговлей квотами:

1. Дополнительные экономические и экологические выгоды. Целевое использование доходов от продажи ЕУК гарантирует, что средства будут инвестированы с большим и долгосрочным экономическим и экологическим эффектом; 
2. Появляются дополнительные возможности привлечения инвестиций от стран и компаний, для которых важны решения экологических проблем. Это может расширить рынок ЕУК;

3. В связи с реализацией ЦЭИ, у властей появляется возможность установки приоритетов на стадии отбора проектов (по их типу, масштабу, месту);

4. ЦЭИ помогают избежать ограничений, которые международное сообщество сформулировало в 6 ст. Киотского протокола, благодаря чему можно упростить подготовку проектов по сравнению с ПСО. ПСО предусматривает обязательную процедуру контроля над каждым проектом, что резко увеличивает операционные издержки. Это не может нравиться инвесторам, особенно в случае с небольшими проектами. ЦЭИ позволяет упростить процедуру контроля, особенно если проекты относятся к числу тех, где легко измерить сокращение эмиссий;

5. Ранние (до 2008 г.) сокращения выбросов могут быть учтены и переданы инвесторам. Это увеличивает экономическую привлекательность проектов и помогает привлечь инвестиции уже на раннем этапе.

Имеет место две концепции «озеленения» ЕУК - «жесткое» и «мягкое» озеленение. «Жесткое озеленение» - инвестирование в проекты, приводящие к прямому сокращению выбросов ПГ, которое может быть измерено в тоннах $\mathrm{CO}_{2}$ экв на количество проданных ЕУК. Однако озеленение в соотношении 1:1 (1 ЕУК на 1 т $\mathrm{CO}_{2}$-экв) считается недостижимым. Поэтому многие страныпродавцы избегают фиксировать количественные соотношения сокращения эмиссий и ЕУК. «Мягкое озеленение» предполагает действия, ведущие к позитивному воздействию на ОС прямо не связанному с конкретными сокращениями эмиссий ПГ, включая повышение информированности населения о необходимости охраны ОС.

Целевые экологические инвестиции способны стать основой отсутствующего на сегодняшний день компенсационного механизма, направленного на финансирование природоохранных мероприятий, и, как 
следствие, улучшения экологической ситуации и повышения инвестиционной активности.

Успешной реализации схемы ЦЭИ может способствовать ряд мероприятий по следующим направлениям [32]:

- назначение ответственных за реализацию схемы ЦЭИ Министерств и ведомств;

- создание нормативно-правовой базы для реализации ЦЭИ;

- проработка механизма получения средств от продажи ЕУК в рамках ЦЭИ;

- проработка механизма отбора природоохранных мероприятий для финансирования в рамках ЦЭИ;

- проработка механизма передачи средств, полученных от продажи ЕУК, для реализации природоохранных мероприятий;

- организация системы контроля за целевым использованием средств, полученных в рамках ЦЭИ.

Экономический инструментарий использования ЦЭИ есть система организации распределения средств, полученных от продажи ЕУК, с присущими ей способами управления и взаимоотношениями между субъектами, направленная на улучшение экономического и экологического состояния территорий. Основные этапы ЦЭИ представлены в табл. 44.

Таблица 44

Основные этапы экономического инструментария использования Целевых экологических инвестиций для финансирования инвестиционных проектов

\begin{tabular}{|c|c|c|}
\hline Этап & Содержание этапа & Участвующий субъект \\
\hline 1 & Разработка инвестиционного проекта & Предприятие \\
\hline 2 & $\begin{array}{l}\text { Подача заявления и сопутствующих документов в } \\
\text { Координационный центр }\end{array}$ & $\begin{array}{l}\text { Предприятие, } \\
\text { Уполномоченный банк }\end{array}$ \\
\hline 3 & $\begin{array}{l}\text { Предварительный отбор проектов, внесение в базу данных } \\
\text { проектов, уведомление предприятий }\end{array}$ & Уполномоченный банк \\
\hline 4 & Заключение договора с 3-ей страной о продаже ЕУК & Правительство страны \\
\hline 5 & Перечисление в бюджет средств от продажи ЕУК & Правительство страны \\
\hline 6 & $\begin{array}{l}\text { Уведомление предприятий о поступлении средств от продажи } \\
\text { ЕУК }\end{array}$ & Сбербанк РФ \\
\hline 7 & $\begin{array}{l}\text { Поиск инвестора, заключение форвардного договора в счет } \\
\text { будущих «углеродных» инвестиций }\end{array}$ & Предприятие \\
\hline 8 & Реализация проекта за счет собственных или заемных средств & Предприятие \\
\hline
\end{tabular}




\begin{tabular}{|c|l|l|}
\hline 9 & $\begin{array}{l}\text { Верификация (подтверждение) сокращения выбросов } \\
\text { парниковых газов }\end{array}$ & $\begin{array}{l}\text { Аккредитованная неза- } \\
\text { висимая организация }\end{array}$ \\
\hline 10 & Перечисление предприятию средств из бюджета & $\begin{array}{l}\text { Правительство страны, } \\
\text { Уполномоченный банк }\end{array}$ \\
\hline
\end{tabular}

Основная цุель экономического инструментария использования ЦЭИ состоит в организац̧ии финансирования инвестиционных проектов предприятий, приводящих к сокращению эмиссий ПГ и антропогенного воздействия на ОС.

В соответствии с данной целью можно определить структуру экономического инструментария использования ЦЭИ как совокупность функциональных подсистем, способствующих достижению согласованных экономических и экологических интересов различных субъектов хозяйствования. Схематично экономический инструментарий использования Целевых экологических инвестиций для финансирования инвестиционных проектов представлен на рис. 23.

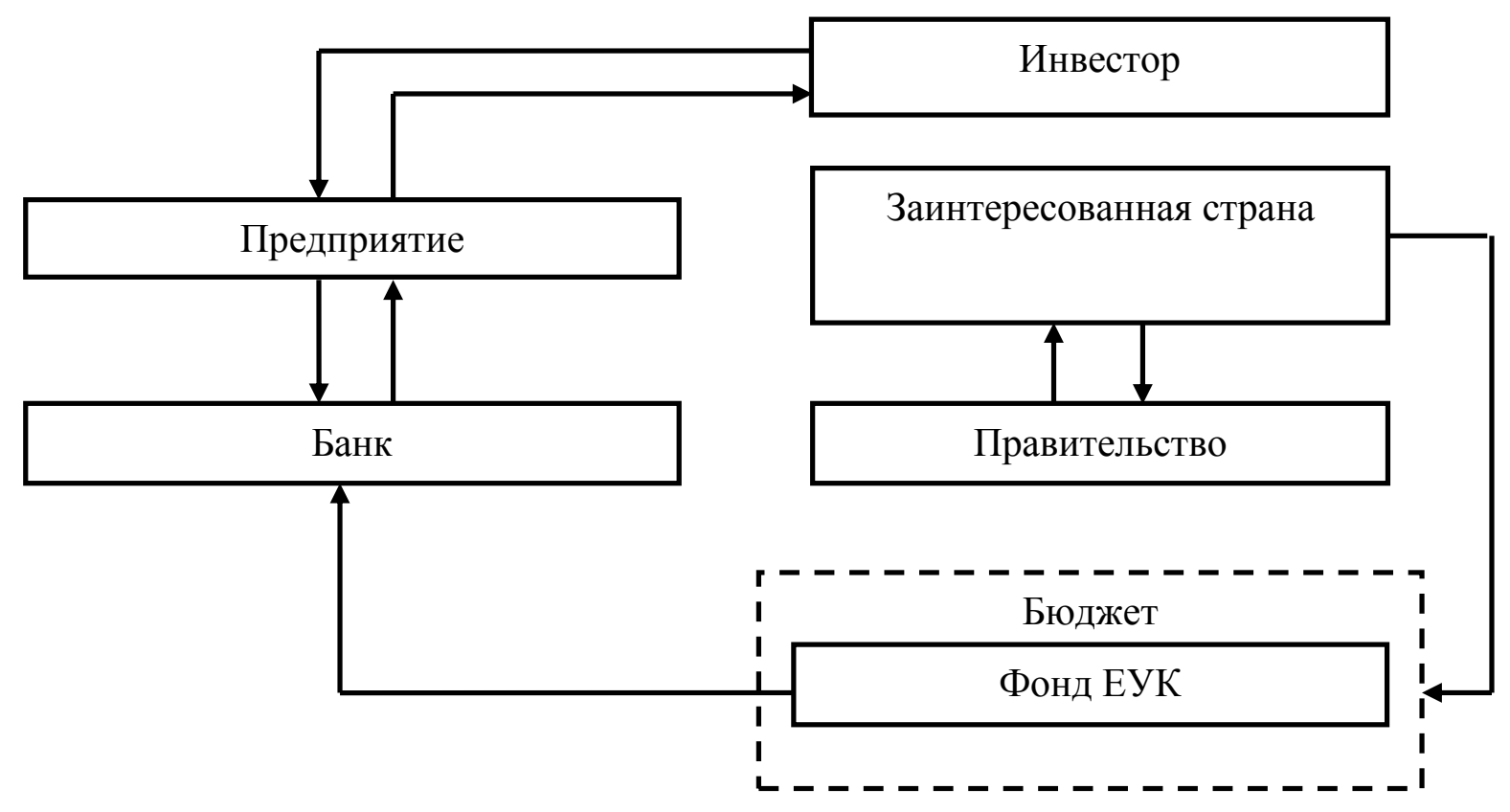

Рис. 23. Экономический инструментарий использования ЦЭИ для финансирования инвестиционных проектов

Субъектами экономического инструментария использования ЦЭИ являются:

- Правительство - устанавливает критерии отбора инвестиционных проектов для реализации по схеме ЦЭИ; утверждает инвестиционные проекты 
для реализации по схеме ЦЭИ; заключает договоры с иностранными государствами, заинтересованными в приобретении ЕУК; определяет политику в отношении количества ЕУК, подлежащих реализации; осуществляет бюджетные операции с ЕУК;

- Банк - координационный центр, осуществляет операции с средствами от продажи ЕУК; обслуживает счета в страновом реестре углеродных единиц; осуществляет конкурсный отбор инвестиционных проектов для реализации по схеме ЦЭИ;

- Предприятие - основной участник схемы ЦЭИ. Представляет инвестиционные проекты и использует средства ЦЭИ для финансирования энергосберегающих, природоохранных инвестиционных проектов.

\section{Вопросы и задания для самопроверки}

1. Раскройте содержание понятия «эмиссия ПГ» и их состав.

2. Назовите эффекты от снижения выбросов ПГ.

3. Финансовые инструменты Киотского протокола.

4. Экономический инструментарий реализации решений Киотского протокола.

\section{Рекомендуемая литература}

1. Проблемы устойчивого развития социально-экономических систем. / А. И. Татаркин, В. В. Криворотов, И. С. Белик [и др.]; под ред. А. И. Татаркина. Изд-во: Экономика, 2012. 555 с.

2. Живая планета 2010 : Биоразнообразие, биоемкость и биоразвитие // Сайт Всемирного фонда дикой природы URL: wwf.ru>data/pub/lpr/1_10.pdf (дата обращения: 10.09.2013). 


\section{Библиографический список}

1. Акимова Т. А. Экономика устойчивого развития : учеб. пособие

/Т. А. Акимова, Ю. Н. Мосейкин. М. : ЗАО Изд-во «Экономика», 2009.

2. Акимова Т. А.Экономика Природы и Человека / Т. А. Акимова, М. Хаскин. М. : ЗАО Изд-во. Экономика, 2006. 334 с.

3. Балацкий О. Ф. Моделирование социо-эколого-экономической системы региона. / О. Ф. Балацкий, В. И. Гурман, Е. В. Рюмина, [и др.]. М. : Наука. 2001.

4. Белик И. С. Методологические основы оценки уровня экологоэкономической безопасности территории / И. С. Белик. // Вестник УГТУ-УПИ № 3 (86). Серия «Экономика и управление»: сборник статей. Екатеринбург : ГОУ ВПО УГТУ-УПИ, 2007.

5. Белик И. С. Влияние Киотских соглашений на инвестиционную привлекательность территории / И. С. Белик, Н. В. Стародубец. // Проблемы современной экономики. Евразийский международный научно-аналитический журнал № 2. СПб. : ЗАО НПФ «Астерион», 2008.

6. Белик И. С. Оценка и диагностика эколого-экономического безопасного развития территории : монография / И. С. Белик. Екатеринбург : УГТУ-УПИ, 2008. $271 \mathrm{c}$.

7. Белик И. С. Влияние эколого-экономической безопасности на выбор стратегических инвестиционных решений / И. С. Белик. Екатеринбург : УГТУУПИ, 2008. 117 с.

8. Белик И. С. Социально-экономическое обоснование экологической безопасности региона : монография / И. С. Белик, А. А. Куклин, Н. Л. Никулина. Екатеринбург : ГОУ ВПО УГТУ-УПИ, 2005. 145с.

9. Вернадский В. И. Биосфера и ноосфера. / В. И. Вернадский. М. : Наука, 1989.

10. Выварец А. Д., Карелов А. С., Полянский А. М. Концептуальные основы формирования механизма оценки эколого-экономической эффективности безотходных производств. / А. Д. Выварец, А. С. Карелов, А. М. Полянский // Российское предпринимательство № 2. Москва : Изд-во «Креативная экономика», 2007. 
11. Выварец А. Д. Оценка воздействия загрязнения атмосферы на здоровье населения /А. Д. Выварец, И. С. Белик // Труды 11 Всерос. симпозиума по экономической теории. Сб. докладов по итогам работы секции «Мезоэкономика: развитие рынка». Екатеринбург : Институт экономики УрО РАН, 2006. 334 с.

12. Гридел Т. Е. Промышленная экология : учеб. пособие для вузов / Т. Е. Гридел, Б. Р. Алленби; пер. с анг. под ред. проф. Э. В. Гирусова. М. : ЮНИТИ-ДАНА, 2004. 527 с. (Серия «Зарубежный учебник»).

13. Гусев А. А. Экономические проблемы природопользования на рубеже XXI века / А. А. Гусев // Ассимиляционный потенциал окружающей среды в системе экономических оценок и прав собственности на природные ресурсы. М. : ТЕИС, 2003.

14. Государственный доклад о состоянии окружающей природной среды и влиянии экологических факторов на здоровье населения Свердловской области в 2009 г. Екатеринбург : Правительство Свердловской области, 2010. 377 с.

15. Инновационный менеджмент : справочное пособие / под ред. П. Н. Завлина, А. К. Казанцева, Л. Э. Миндели. СПб. : Наука, 1997. 559 с.

16. Интегральные показатели эколого-экономического состояния территории и их использование для прогнозирования социально-экономического развития Свердловской области / А. Д. Выварец, И. С. Белик [и др.]. Екатеринбург : ГОУ ВПО УГТУ-УПИ, 2003. 99 с.

17. Исаев В. В. Общая теория социально-экономических систем : учеб. пособие / В. В. Исаев, А. М. Немчин. СПб. : Изд. дом «Бизнес-пресса», 2002. 176 с.

18. Каталог биосферы / пер. с англ. М. : Мысль, 1991.

19. Коробова Н. Л. Анализ затрат на охрану окружающей среды в ННГ. Отчет по России / Н. Л. Коробова, Й. Й. Йоргенсен. ОЭСР, Датское агенство по охране окружающей среды. 2000.

20. Критерии оценки экологической обстановки территорий для выявления зон чрезвычайной экологической ситуации и зон экологического бедствия // Зеленый мир. 1994. № 11-14. 
21. Колесников С. И. Экология : учеб.пособие / С. И. Колесников. - 3-е изд. М. : Изд-во «Дашков и К ${ }^{0} » ;$ Ростов н/Д: Академцентр, 2009. 384 с.

22. Масленникова И. С. Управление экологической безопасность и рациональным использованием природных ресурсов : учебник / И. С. Масленникова, В. В. Горбунова. СПб. : СПбГИЭУ, 2011. 566 с.

23. Методика определения предотвращенного экологического ущерба. М. : Государственный комитет РФ по охране окружающей среды, 1999. 71 с.

24. Мекуш Г. Е. Экологическая политика и устойчивое развитие: анализ и методические подходы / Г. Е. Мекуш; под ред. С. Н. Бобылева; Кемеровский гос. ун-т. М. : Экономика, 2011. 255 с.

25. Орехов Н. А. Математическое моделирование в экологии / Н. А. Орехов, А. С. Гринин, В. Н. Новиков. М. : ЮНИТИ, 2003. 248 с.

26. Охрана атмосферного воздуха: сборник нормативных документов. Екатеринбург : ИД «УралЮрИздат», 2006. 200 с.

27. Оценка загрязнения атмосферы промышленными выбросами : монография / А. Д. Выварец, И. С. Белик, Ю. В. Леонтьева [и др.]. Екатеринбург : ГОУ ВПО УГТУ-УПИ, 2006. 108 с.

28. Охрана окружающей среды в России: статистический сборник / Госкомстат России. М., 2001. 229 с.

29. Пахомова Н. В. Экономика природопользования и экологический менеджмент. / Н. В. Пахомова, К. К. Рихтер. СПб. : Издательство С.-Петербургского ун-та, 1999. 196 с.

30. Парсаданов Г. А. Прогнозирование национальной экономики : учеб. пособие / Г. А. Парсаданов, В. В. Егоров. М. : ИНФРА-М, 2001. 184 с.

31. Печчеи Аурелио. Человеческие качества / Аурелио Печчеи; пер. с англ. О. В. Захаровой. М. : Изд-во Прогресс, 1980. 304 с.

32. Проблемы устойчивого развития социально-экономических ситсем. / А. И. Татаркин, В. В. Криворотов, И. С. Белик [и др.]; под ред. А. И. Татаркина. Изд-во: Экономика, 2012. 555 с.

33. Ревич Б. А. Методика оценки экономического ущерба здоровью населения от 
загрязнения атмосферного воздуха: пособие по региональной экологической политике / Б. А. Ревич, В. Н. Сидоренко. М. : Акрополь, ЦЭПР. 2006.

34. Реймерс Н. Ф. Природопользование : словарь-справочник / Н. Ф. Реймерс. М., 1990.

35. Руководство по проведению стратегической экологической оценки. М. : ИД РПОИ, 2006.

36. Региональный план действий по охране окружающей среды для Свердловской области на период до 2015 г. Екатеринбург : ЦПРП, 2001. 245 с. 37. Регионы России. Социально-экономические показатели. 2007: статистический сборник / Федеральная служба государственной статистики. М., 2007. $863 \mathrm{c}$.

38. Эколого-экономическая безопасность территории: понятийный аппарат и методы оценки / А. Д. Выварец, И. С. Белик. Наука // Общество. Человек. Вестник УрО РАН Экономика. Политика. Право. К 35-летию Института экономики УрО РАН. Екатеринбург : УрО РАН, 2006.

39. Экономический анализ воздействия на окружающую среду / А. Джон [и др.]. М. : Вита, 2000. 230 c.

40. Экономическая безопасность России: уроки кризиса и перспективы роста / А. И. Татаркин, М. В. Федорова, И. С. Белик [и др.]; под ред. А. И.Татаркина. Изд-во: Экономика, 2012. 1130 с.

41. Эннос А. Р. Биология окружающей среды / А. Р. Эннос, С. Э. Бейли; пер. с англ. М. : Колос, 1997.

42. Belic I. The Role of Kioto protocol in increasinq the investment attractiveness of the territory / I. Belic, A. Vyvarets // The international collected scientific work by economic security's problem: society, state and region. Ekaterinburq : IE UB RAS. 2008. P. $179-188$

43. Данные о составлении рейтингов эколого-энергетической эффективности регионов России // Независимое экологическое рейтиноговое агенство URL: http:// near.biodat.ru / ratings/regions (дата обращения: 30.09.2013). 
44. Оптимизация мониторинга техногенного загрязнения среды обитания в целях дозовой оценки вредной экспозиции населения: методические рекомендации // Сайт информационных технологий URL: http://inftech.webservis.ru (дата обращения: 30.09.2013).

45. Московский центр программы ГРИД URL: http:/grid.ecoinfo.ru (дата обращения: 30.09.2013).

46. Российский региональный экологический центр URL: http://rusrec.ru (дата обращения: 30.09.2013). 


\section{Приложение 1}

\section{Понятийный аппарат ЭЭБ}

\begin{tabular}{|c|c|}
\hline $\begin{array}{c}\text { Понятийный } \\
\text { аппарат }\end{array}$ & Содержание цели, задач, предмета, объекта ЭЭБ \\
\hline Цель & $\begin{array}{l}\text { Развитие эколого-экономических отношений в благоприятных для природы } \\
\text { и общества направлениях, обеспечивающих экономическое благополучие, } \\
\text { качественные условия жизнедеятельности и состояние здоровья человека }\end{array}$ \\
\hline Задачи & $\begin{array}{l}\text { Обоснование с учетом экофактора экономически сбалансированного } \\
\text { размещения производительных сил. } \\
\text { Законодательное закрепление обязательных экологических требований и } \\
\text { запрещения организации и ведения хозяйственной деятельности, } \\
\text { оказывающей негативное влияние на состояние ПС. } \\
\text { Совершенствование системы управления природными ресурсами в рамках } \\
\text { социально-экономической политики государства с соответствующим } \\
\text { определением необходимых изменений в госполитике по данным вопросам. } \\
\text { Изучение причин деградации ОС и взаимосвязи социальных, } \\
\text { экономических и экологических факторов, оказывающих влияние на этот } \\
\text { процесс. } \\
\text { Оценка влияния деградации ПС на хозяйственное развитие региона. } \\
\text { Разработка прогнозов социально-экономической динамики территории, } \\
\text { основанных на критериях безопасного развития. } \\
\text { Снижение уровня техногенной нагрузки на ПС посредством совершенство- } \\
\text { вания экономических методов использования отходов и др }\end{array}$ \\
\hline Предмет & $\begin{array}{l}\text { Совокупность эколого-экономических отношений, возникающая между } \\
\text { структурообразующими и хозяйствующими субъектами территории, } \\
\text { населением и окружающей природной средой по поводу сохранения ее } \\
\text { качественного состояния, реализации социально-экономических интересов } \\
\text { субъектов и условий жизни населения }\end{array}$ \\
\hline Объект & $\begin{array}{l}\text { Условия устойчивого безопасного развития производства, определяемые } \\
\text { через установление экологической емкости и хозяйственного потенциала } \\
\text { территории. } \\
\text { Условия жизнедеятельности и качество среды обитания человека. } \\
\text { Земля, ее недра, поверхностные и подземные воды, атмосферный воздух, } \\
\text { леса и иная растительность, природные ландшафты, используемые в } \\
\text { хозяйственной деятельности и включаемые в рыночный оборот. Различные } \\
\text { виды деятельности субъектов - природопользователей и техносфера }\end{array}$ \\
\hline
\end{tabular}




\section{Приложение 2}

\section{Источники загрязнения атмосферного воздуха [21]}

Основными антропогенными источниками загрязнения атмосферного воздуха являются следующие отрасли экономики: теплоэнергетика (тепловые и атомные электростанции, промышленные и городские котельные), автотранспорт, черная и цветная металлургия, нефтедобывающее и нефтеперерабатывающее производство, машиностроение, производство стройматериалов и т.д.

Энергетика. При сжигании твердого топлива (каменного угля) в атмосферный воздух поступают оксиды серы, оксиды азота, твердые частицы (пыль, сажа, зола). Так, современная теплоэлектростанция мощностью 2,4 млн кВт расходует до 20 тыс. т угля в сутки и выбрасывает в атмосферу в сутки 680 т $\mathrm{SO}_{2}$ и $\mathrm{SO}_{3} ; 120$ - 140 т твердых частиц (зола, пыль, сажа); 200 т оксидов азота. Использование жидкого топлива (мазута) снижает выбросы золы, но практически не уменьшает выбросы оксидов серы и азота. Газовое топливо загрязняет атмосферный воздух в 3 раза меньше, чем мазут и в 5 раз меньше, чем уголь. Атомная энергетика в случае безаварийной работы экологичнее, но и она загрязняет воздух такими токсичными веществами, как радиоактивный йод, радиоактивные инертные газы и аэрозоли

Черная и иветная металлургия. При выплавке одной тонны стали в атмосферу выбрасывается 0,04 т твердых частиц, 0,03 т оксида серы, 0,05 т оксида углерода, а также в меньших количествах свинец, фосфор, марганец, мышьяк, пары ртути, фенол, формальдегид, бензол, аммиак и другие токсичные вещества. В выбросах предприятий цветной металлургии содержатся тяжелые металлы, такие, как свинец, цинк, медь, алюминий, ртуть, кадмий, молибден, никель, хром и др.

Химическая промышиленность. Выбросы химической промышленности характеризуются значительным разнообразием, высокой 
концентрированностью и токсичностью. Они содержат оксиды серы, соединения фтора, аммиак, нитрозные газы, хлористые соединения, сероводород, неорганическую пыль и др.

Автотранспорт. В настоящее время в мире эксплуатируется несколько сот миллионов автомобилей. Выхлопные газы двигателей внутреннего сгорания содержат огромное количество токсичных соединений: бенз(а)пирена, альдегидов, оксидов азота и углерода и особо опасных соединений свинца. В настоящее время в крупных городах России выбросы от автотранспорта превосходят выбросы от стационарных источников (промпредприятия).

Сельское хозяйство. Сельскохозяйственное производство приводит к загрязнению атмосферного воздуха пылью (при механической обработке почв), метаном (домашние животные), сероводородом и аммиаком (промышленные комплексы по производству мяса), пестицидами (при их распылении) и т. д. Интенсивное загрязнение атмосферного воздуха отмечается также при добыче и переработке минерального сырья, на нефте- и газоперерабатывающих заводах, при выбросе пыли и газов из подземных горных выработок, при сжигании мусора и горении пород в отвалах и т.д.

\section{Защита атмосферы [46]}

В целях защиты атмосферы от загрязнения применяют следующие экозащитные мероприятия [46]: 1) экологизация технологических процессов; 2) очистка газовых выбросов от вредных примесей; 3) рассеивание газовых выбросов в атмосфере; 4) соблюдение нормативов допустимых выбросов вредных веществ; 5) устройство санитарно-защитных зон, архитектурнопланировочные решения.

1. Экологизация технологических процессов - это в первую очередь создание замкнутых технологических циклов, безотходных и малоотходных технологий, исключающих попадание в атмосферу вредных загрязняющих веществ. Кроме того необходима предварительная очистка топлива или замена его более экологичными видами, применение гидрообеспыливания, рециркуляция газов, перевод различных агрегатов на электроэнергию и др. Актуальнейшая задача 
современности - снижение загрязнения атмосферного воздуха отработанными газами автомобилей. В настоящее время ведется активный поиск альтернативного, более «экологически чистого» топлива, чем бензин. Продолжаются разработки двигателей автомобилей, работающих на электроэнергии, солнечной энергии, спирте, водороде и др.

2. Очистка газовых выбросов от вредных примесей. Нынешний уровень технологий не позволяет добиться полного предотвращения поступления вредных примесей в атмосферу с газовыми выбросами. Поэтому повсеместно используются различные методы очистки отходящих газов от аэрозолей (пыли) и токсичных газо- и парообразных примесей (NO, $\mathrm{NO}_{2}, \mathrm{SO}_{2}, \mathrm{SO}_{3}$ и др.). Для очистки выбросов от аэрозолей применяют различные типы устройств в зависимости от степени запыленности воздуха, размеров твердых частиц и требуемого уровня очистки: сухие пылеуловители (циклоны, пылеосадительные камеры), мокрые пылеуловители (скрубберы и др.), фильтры,, электрофильтры: каталитические, абсорбциионые, адсорбционные и другие методы для очистки газов от токсичных газо- и парообразных примесей.

3. Рассеивание газовых примесей в атмосфере - это снижение их опасных концентраций до уровня соответствующего ПДК путем рассеивания пылегазовых выбросов с помощью высоких дымовых труб. Чем выше труба, тем больше ее рассеивающий эффект. К сожалению, этот метод позволяет снизить локальное загрязнение, но при этом проявляется региональное.

4. Устройство санитарно-защитных зон и архитектурно-планировочные мероприятия. Санитарно-защчитная зона (С33) - это полоса, отделяющая источники промышленного загрязнения от жилых или общественных зданий для защиты населения от влияния вредных факторов производства. Ширина этих зон составляет от 50 до 1000 м в зависимости от класса производства, степени вредности и количества выделяемых в атмосферу веществ. При этом граждане, чье жилище оказалось в пределах С33, защищая свое конституционное право на благоприятную среду, могут требовать либо прекращения экологически опасной деятельности предприятия, либо переселения за пределы С33. 
Архитектурно-планировочные мероприятия включают правильное взаимное размещение источников выброса и населенных мест с учетом направления ветров, выбор под застройку промышленного предприятия ровного возвышенного места, хорошо продуваемого ветрами. 
Приложение 3

\section{Виды антропогенного загрязнения вод $[21,22]$}

Химическое загрязнение - загрязнение вод неорганическими и органическими веществами. Из органических загрязнителей наиболее распространены нефть и нефтепродукты, СПАВ, фенолы, пестициды и др., из неорганических - кислоты, щелочи, тяжелые металлы (ртуть, свинец, кадмий, мышьяк и др.). Химическое загрязнение наиболее распространенное, стойкое и далеко распространяющееся загрязнение гидросферы. При осаждении на дно водоемов или при фильтрации в грунтовые воды вредные химические вещества сорбируются частицами пород, окисляются и восстанавливаются, выпадают в осадок и т. д. Однако, как правило, полного самоочищения загрязненных вод не происходит.

Биологическое загрязнение - загрязнение вод патогенными микроорганизмами бактериями, вирусами, простейшими, грибами, мелкими водорослями и др.

Радиоактивное загрязнение - загрязнение вод радионуклидами. Оно опасно даже при очень малых концентрациях радиоактивных веществ, особенно «долгоживущих» и подвижных в воде радиоактивных элементов (стронций - 90, уран, радий - 226, цезий и др.). Радионуклиды попадают в поверхностные водоемы при сбрасывании радиоактивных отходов, захоронении их на дне и др., в подземные воды - в результате просачивания вглубь земли вместе с атмосферными водами или в результате взаимодействия подземных вод с радиоактивными горными породами.

Механическое загрязнение - загрязнение вод механическими примесями твердыми частицами (песок, ил, шлам и др.). Свойственно в основном поверхностным водам. При этом наиболее значительно ухудшаются органолептические показатели воды.

Тепловое загрязнение - это повышение температуры вод в результате их смешивания с более нагретыми поверхностными или технологическими водами 
(тепловых и атомных электростанций). При повышении температуры происходит изменение газового и химического состава вод, что ведет к размножению анаэробных бактерий и выделению ядовитых газов - сероводорода, метана. Одновременно происходит «цветение» воды вследствие ускоренного развития фитопланктона.

\section{Источники загрязнения гидросферы}

Основными антропогенными источниками загрязнения поверхностных вод являются: 1) сбросы в водоемы неочищенных сточных вод; 2) смыв пестицидов, минеральных и органических удобрений; 3) газодымовые выбросы; 4) утечки нефти и нефтепродуктов.

1. Сбросы в водоемы неочищенных сточных вод оказывают наибольший вклад в загрязнение гидросферы. Сточные воды классифицируются на промышленные, коммуналъно-бытовые, коллекторно-дренажные и др. Промышленные сточные воды в зависимости от специфики отраслей промышленности содержат нефтепродукты, фенолы, СПАВ, сульфаты, фториды, цианиды, тяжелые металлы и т. д.

2. Смыв пестицидов, минеральных и органических удобрений. При неправильном хранении и внесении в почву пестицидов, минеральных и органических удобрений возможен смыв их ливневыми водами в водоемы и водотоки. Поступление в водоемы пестицидов ведет к болезням и гибели гидробионтов. Загрязнение вод биогенными элементами и органическими веществами приводит к эвтрофикации, цветению вод, «красным приливам».

3. Газодымовые выбросы попадают в водные объекты в процессе механического оседания или с осадками. Они содержат твердые частицы, оксиды серы и азота, тяжелые металлы, углеводороды, альдегиды и др. Оксиды серы, оксиды азота, сероводород, хлороводород, взаимодействуя с атмосферной влагой, образуют кислоты и выпадают в виде кислотных дождей, закисляя водоемы.

4. Утечки нефти и нефтепродуктов. Миллионы тонн нефти ежегодно загрязняют морские и пресноводные экосистемы при авариях нефтеналивных 
судов, на нефтепромыслах в прибрежных зонах, при сбросе с судов балластных вод и т.Д.

В подземные воды загрязняющие вещества могут проникать различными путями: при просачивании промышленных и коммунальнобытовых стоков из хранилищ, прудов-накопителей, отстойников и др., по затрубному пространству неисправных скважин, через поглощающие скважины, карстовые воронки и т. д.

\section{Защита гидросферы [22]}

Поверхностные воды защищают от засорения, загрязнения и истощения. Для защиты от засорения предотвращают попадание в поверхностные водоемы и реки различных твердых отходов и других предметов. Для защиты от истощения контролируют минимально допустимые стоки вод. Для защиты от загрязнения применяют следующие мероприятия:

- развитие безотходных и безводных технологий и оборотного водоснабжения;

- очистка сточных вод (промышленных, коммунально-бытовых и др.);

- закачка сточных вод в глубокие водоносные горизонты (подземное захоронение);

- очистка и обеззараживание поверхностных вод, используемых для водоснабжения и других целей.

Безотходные и безводные технологии и оборотное водоснабжение.

Главный загрязнитель поверхностных вод - сточные воды. Наиболее действенным способом зашиты поверхностных вод от загрязнения сточными водами являются безводные и безотходные технологии. На начальном этапе создается оборотное водоснабжение. В его систему включают ряд очистных сооружений и установок, что создает замкнутый цикл использования сточных вод, которые при таком способе все время находятся в обороте и не попадают в поверхностные водоемы.

Очистка сточных вод. Существуют различные способы очистки сточных вод: механический, физико-химический, химический, биологический и 
термический. В зависимости от вида сточных вод их очистка может производиться каким-либо одним или комбинированными способами, с обработкой осадка (или избыточной биомассы) и обеззараживанием сточных вод перед сбросом их в водоем.

Механическая очистка основана на процеживании, отстаивании и фильтровании. При этом из сточных вод удаляются нерастворимые механические примеси: песок, глинистые частицы, окалина и др. Физикохимическая очистка предполагает коагуляцию, сорбцию, флотацию, экстракцию и другие методы. Из сточных вод удаляются тонкодисперсные взвешенные частицы, минеральные и органические вещества. Химическая очистка основана на процессах нейтрализации, окисления, озонировании, хлорировании. Сточные воды очищаются от токсичных веществ и микроорганизмов. Биологическая (биохимическая) очистка основана на способности микроорганизмов использовать для своего питания многие органические и неорганические соединения из сточных вод (сероводород, аммиак, нитриты и т. д.). К термическим методам прибегают при очистке промышленных сточных вод, содержащих главным образом высокотоксичные органические компоненты, разрушающиеся при высоких температурах.

При всех методах очистки сточных вод необходима обработка и утилизация образующихся шламов и осадков (особенно при очистке токсичных промстоков). С этой целью их складируют на специальных полигонах, обрабатывают в биологических сооружениях, перерабатывают с помощью растений (гиацинты, тростник и др.) или сжигают в специальных печах.

Закачка сточных вод в глубокие водоносные горизонты (подземное захоронение) осуществляется через систему поглощающих скважин. При этом способе отпадает необходимость в дорогостоящей очистке и обезвреживании сточных вод и в сооружении очистных сооружений.

Агролесомелиорация и г гидротехнические мероприятия защищают поверхностные воды от загрязнения и засорения. Они предотвращают эвтрофикацию озер, водохранилищ и малых рек, возникновение эрозии, 
оползней, обрушение берегов, уменьшают загрязненный поверхностный сток. Водоохранные зоны защищают поверхностные воды от загрязнения, засорения и истощения. Они создаются на всех водных объектах. Их ширина на реках составляет от 0,1 до 1,5 - 2,0 км, включая пойму реки, террасы и береговой склон. В пределах этих зон запрещается распашка земель, выпас скота, применение пестицидов и удобрений, строительные работы и др.

Подземные воды охраняют от загрязнения и истощения. Для защиты от истощения применяют:

- регулирование режима водозабора подземных вод;

- рациональное размещение водозаборов по площади;

- определение величины эксплуатационных запасов как предела их рационального использования;

- введение кранового режима эксплуатации самоизливающихся артезианских скважин и др.

Для защиты подземных вод от загрязнения применяют две группы мероприятий: профилактические и специальные. Профилактические мероприятия направлены на предупреждение загрязнения. Они предусматривают устройство зон санитарной охраны (ЗСО) - территорий вокруг источников централизованного питьевого водоснабжения, создаваемых для исключения возможности загрязнения подземных вод.

Специальные мероприятия направлены на локализацию или ликвидацию очага загрязнения. Они предусматривают изоляцию источников загрязнения от остальной части водоносного горизонта (завесы, противофильтрационные стенки), а также на перехват загрязненных подземных вод с помощью дренажа. Для ликвидации локальных очагов загрязнения ведут длительные откачки загрязненных подземных вод.

Основами водного законодательства запрещены проектирование, строительство и ввод в эксплуатацию предприятий, не обеспеченных водоочистными устройствами. Сброс отработанных вод допускается только с разрешения органов, контролирующих качество воды. 


\section{Приложение 4}

\section{Защита почв [21]}

В целях защиты почв от деградации применяют следующие экозащитные мероприятия: 1) защита почв от водной и ветровой эрозии; 2) рекультивация нарушенного почвенного покрова; 3) защита почв от дегумификации, почвоутомления и истощения; 4) защита почв от засоления, осолонцевания и слитизации; 5) защита почв от загрязнения продуктами техногенеза (тяжелыми металлами, нефтью, нефтепродуктами, пестицидами, радионуклидами др.).

Защита почв от водной и ветровой эрозии включает организационнохозяйственные, агротехнические, лесомелиоративные и гидротехнические мероприятия.

Организационно-хозяйственные мероприятия. Включают обоснование и составление плана противоэрозионных мероприятий и обеспечение его выполнения (рациональное распределение земельных угодий, почвозащитные севообороты, земледелие полосами, регулирование выпаса скота и др.)

Агротехнические мероприятия включают приемы фитомелиорации (севообороты с многолетними травами, замена чистых паров на занятые, сидеральные и кулисные), противоэрозионную обработку почвы (обработка почв по горизонтали, «контурное» земледелие, щелевание и кротование почв, обвалование, безотвальная вспашка с сохранением стерни и пожнивных остатков), снегозадержание и регулирование снеготаяния (лесные полосы и кулисы, пахота снега, прикатывание).

Лесомелиоративные мероприятия основаны на создании лесных защитных насаждений (ветрозащитные и приовражные лесные полосы, полезащитные лесные и кустарниковые полосы поперек склонов и т. д.).

Гидротехнические мероприятия применяют в тех случаях, когда другие приемы не в состоянии предотвратить эрозию и основаны на создании гидротехнических сооружений, обеспечивающих задержание или регулирование 
склонового стока (террасирование склонов, выполаживание оврагов бульдозерами, закрепление склонов оврагов).

Рекультиваџия земель - мероприятия по восстановлению и оптимизации нарушенных ландшафтов. Она включает комплекс горно-технических, мелиоративных, сельскохозяйственных, лесохозяйственных и инженерностроительных работ, направленных на восстановление нарушенного плодородия земель. Рекультивация включает три этапа: подготовительный, горно-техническая рекультивация и биологическая рекультивация предполагает обследование нарушенных территорий: определяют направление рекультивации, составляют технико-экономическое обоснование и проект рекультивации. Наиболее дешевым видом освоения рекультивируемых территорий является облесение. Для улучшения свойств верхнего слоя отвалов, для накопления в нем органического вещества и азота перед посадкой деревьев высевают люпин, донник или люцерну с последующей их запашкой. Деревья сажают саженцами в заполненные нетоксичной породой или почвой ямки или борозды. При рекультивации земель в сельскохозяйственные угодья проводят известкование, рыхление до глубины 60 см, внесение удобрений, посев злаково-бобовой смеси. После этого вводят специальный севооборот, где 40 - 50\% составляют многолетние травы. После такого «севооборота» рекультивируемые земли могут быть заняты зональным полевым или кормовым севооборотом.

Защита почв от дегумификации, почвоутомления и истощения включает следующие мероприятия: применение органических удобрений, известкование кислых почв, использование в севообороте многолетних трав, регулирование соотношения в севооборотах пропашных культур и культур сплошного сева, использование щадящей обработки почвы (облегчение машин, минимизация обработки).

Защита почв от засоления, осолонщевания и слитизации. Защита почв от потерь поливной воды и вторичного засоления включает следующие мероприятия: создание закрытой сети каналов, исключающих фильтрацию; создание дренажных сооружений, обеспечивающих удержание соленых грунтовых вод на 
глубине не менее 1,5 - 3 м; капитальные промывки почв, если они засолены, для удаления солей из корнеобитаемого горизонта; регулярные вегетационные поливы с дренажными водоотводами.

Защита почв от содового засоления и слитости включает следующие мероприятия: химическая мелиорация (внесение гипса), применение физиологически кислых и кальцийсодержащих удобрений, включение в севооборот многолетних трав.

Защита почв от загрязнения продуктами техногенеза (тяжелыми металлами, нефтью, нефтепродуктами, пестицидами, радионуклидами и т. д.) осуществляется двумя путями. Первый путь состоит в предотвращении попадания загрязняющих веществ в почву. Второй заключается в очищении, тем или иным образом, почвы от загрязнения, которое уже произошло. Очищение может производиться путем удаления верхнего загрязненного слоя почвы, путем промывок или извлечения загрязняющих веществ из почвы с помощью растений (для тяжелых металлов и радионуклидов), интенсификации микробного разложения органических загрязнителей (для нефтепродуктов и пестицидов) и т. д. Еще один подход основан на закреплении атомов токсичных элементов в почве, с целью недопущения попадания их в сопредельные среды и живые организмы. Для этого используют внесение в почву органического вещества, фосфорных минеральных удобрений, ионообменных смол, природных цеолитов, бурого угля, известкование почвы и т. д. 
Учебное издание

Белик Ирина Степановна

ЭКОЛОГО-ЭКОНОМИЧЕСКАЯ БЕЗОПАСНОСТЬ

Редактор О. В. Гусева

Компьютерный набор И. С. Белик

Компьютерная верстка В.К. Матвеева 
Подписано в печать 22.11.2013. Формат 70х100 1/16. Бумага писчая. Плоская печать. Усл. печ. л. 18,06. Уч.-изд. л. 10,7. Тираж 160 экз. Заказ 2309.

Издательство Уральского университета Редакционно-издательский отдел ИПЦ УрФУ 620049, г. Екатеринбург, ул. С. Ковалевской, 5

Тел. 8(343) 375-48-25, 375-46-85, 374-19-41

E-mail: rio@ustu.ru

Отпечатано в Издательско-полиграфическом центре УрФУ

620000. г. Екатеринбург, ул. Тургенева, 4

Тел. +7(343)358-93-06

E-mail: press-urfu@mail.ru 